\author{
UNIVERSIDADE DE SÃO PAULO \\ Faculdade de Economia, Administração e Contabilidade \\ Departamento de Administração
}

\title{
NegócIOS SOCIAIS E INOVAÇão SOCIAL: UM RETRATO DE EXPERIÊNCIAS BRASILEIRAS
}

Profa. Dra. Graziella Maria Comini

São Paulo 
Prof.Dr. Marco Antonio Zago

Reitor da Universidade de São Paulo

Prof.Dr. Adalberto Américo Fischmann

Diretor da Faculdade de Economia, Administração e Contabilidade

Prof.Dr. Roberto Sbragia

Chefe do Departamento de Administração

Prof. Dr. Moacir de Miranda Oliveira Júnior

Coordenador do Programa de Pós-Graduação em Administração 


\section{Graziella Maria Comini}

\section{Negócios SoCIAIS E InOVAÇÃo SOCIAL:}

\section{UM RETRATO DE EXPERIÊNCIAS BRASILEIRAS}

Tese apresentada ao Departamento de Administração da Faculdade de Economia, Administração e Contabilidade da Universidade de São Paulo, como requisito para obtenção do Título de Livre-Docente em Administração.

São Paulo 


\section{FICHA CATALOGRÁFICA}

Elaborada pela Seção de Processamento Técnico do SBD/FEA/USP

Comini, Graziella Maria.

Negócios sociais e inovação social: um retrato de experiências brasileiras / Graziella Maria Comini. -- São Paulo, 2016. $166 \mathrm{p}$.

Tese (Livre-Docência) - Universidade de São Paulo, 2016.

1. Empreendedorismo social. 2. Inovação social. 3. Negócio social. 4. Valor socioambiental. 5. Inovação. I. Universidade de São Paulo. Faculdade de Economia, Administração e Contabilidade. II. Título.

CDD -361.2 
Ao meu pai e à minha mãe do coração, Rosa Maria, por estarem sempre ao meu lado e serem uma fonte inesgotável de aprendizado. 



\section{Agradecimentos}

A elaboração de uma tese é muito parecida com gestação de um filho. Durante o processo, momentos de angústia quase insuportáveis de ficar horas e horas para escrever uma página de texto, o cansaço de inúmeras revisões, a impaciência de efetuar mais um aprimoramento e a ansiedade de chegar ao fim. No nascimento, vem a satisfação, a grande alegria de ter conseguido materializar um estudo que envolveu muitos meses e que só foi possível graças à ajuda e ao apoio de muitas pessoas, "padrinhos e madrinhas" deste novo filho que nasce agora.

À minha eterna orientadora Rosa Maria Fischer, que ajudou a gestar as ideias deste trabalho. Esteve sempre presente, como "mãe" e amiga, dando força e estímulo. Como parceira acadêmica e colega de trabalho, fazendo sugestões e críticas, sempre precisas e pertinentes, e indicando o caminho para eu pudesse encontrar a luz no final do túnel.

À amiga Felicia Ponce, que acompanhou todo o desenvolvimento deste trabalho, me deu força, carinho e ofereceu seus "ouvidos" para que eu pudesse desabafar sobre as idas e vindas do trabalho e sobre a tensão dos momentos finais. Foi também solidária ao ler pacientemente todo o trabalho e generosa ao compartilhar seus conhecimentos metodológicos.

Ao amigo Roberto Sbragia, que me encorajou a escrever a tese de livre-docência e proporcionou trocas sempre frutíferas de ideias e conhecimento. Como chefe de Departamento, foi paciente e solidário no momento final de elaboração da tese, ficando temporariamente sem coordenadora do curso de graduação, a qual estava envolvida de corpo e alma na preparação da livre-docência.

Aos amigos do Instituto de Pesquisas Ecológicas (Ipê) - Pádua, Suzana, Ditt, Andrea, Cristi, Badialli, entre outros - que me acolheram na "família" e foram generosos ao compartilhar sua "sabedoria" socioambiental. Como visionários, me ensinaram que devemos ter humildade, paciência, flexibilidade, disposição e otimismo para construir um mundo melhor.

À Alda, pela lealdade, solidariedade e disponibilidade em tomar as necessárias providências para que eu pudesse finalizar a tempo este trabalho. Como fiel escudeira, me protegeu e filtrou as demandas do dia a dia. 
À Juliana Rodrigues, pela disponibilidade e talento no trabalho de revisão e edição do texto. Sua leveza e alegria são contagiantes, seu entusiasmo transformou a relação de orientação em uma relação de amizade e de aprendizado mútuo.

Aos atuais orientandos de graduação (Victor, João, Ana, Lais), mestrado profissional (Fernanda, Guilherme e Leonardo), mestrado (Juliana e Marise), doutorado (Edison, Talita e Nadir), que embarcaram comigo no sonho de desbravar as trilhas do empreendedorismo social e foram compreensivos na reta final, suportando a demora de minhas respostas às suas demandas específicas. Edison, obrigada pelas sugestões e leitura minuciosa no final.

A Rockefeller Foundation, Omidyar, Fundação Avina e Instituto de Cidadania Empresarial pelo apoio financeiro para o desenvolvimento da pesquisa Brasil27.

Ao Pedro Henrique Vitoriano e Fábio Serconek, que me contagiaram com seu sonho de viajar pelos 27 estados brasileiros para conhecer experiências bem sucedidas de negócios sociais. Sem a dedicação e empolgação deles não haveria matéria-prima suficiente para desenvolver esta tese.

A todos os fundadores e gestores dos empreendimentos sociais que participaram da pesquisa Brasil27 pela abertura e disponibilidade para atender a equipe de pesquisa.

A toda equipe da Secretaria de Graduação de Administração que foram compreensivas com minha ausência na reta final e, principalmente, a Profa. Dra. Rosana Tavares, companheira na coordenação do curso, que me aliviou das atividades de rotina, tornando possível uma dedicação integral a tese.

Ao meu pai Renzo Comini e minhas filhas, Malu e Bebel, que me apoiaram ao longo do desenvolvimento do trabalho de diferentes formas: com palavras de estímulo, com paciência nos momentos de ausência, com ajuda técnica na elaboração de figuras, com abraços afetuosos e sorrisos encantadores nos momentos mais tensos. Obrigada aos três por fazerem minha vida mais prazerosa e iluminada. Vocês serão sempre minha fonte de inspiração. 
"Sem o setor privado, o desenvolvimento sustentável continuará sendo apenas um sonho distante. Não estamos pedindo às empresas que façam algo diferente de seus próprios negócios. Estamos pedindo que façam seus negócios de maneira diferente"

(Kofi Annan) 



\section{Resumo}

A emergência e a expansão de negócios sociais em diferentes partes do globo tornam esse fenômeno foco de estudo das ciências administrativas, tanto para conhecer suas características empíricas, como para modelar ferramentas de gestão apropriadas. Este trabalho teve como objetivo contribuir para o avanço do campo de estudos sobre empreendimentos sociais, particularmente sob a dimensão de inovação social, por ter identificado algumas lacunas na literatura, dentre as quais: imprecisa distinção entre determinantes e dimensões analíticas da inovação; raros estudos sob a lente de resultado, e a maioria dos trabalhos associa inovação social apenas às organizações sem fins lucrativos. A partir destas lacunas, delineou-se o problema de investigação: até que ponto os modelos de negócios sociais são geradores de inovação socioambiental? Este estudo deu continuidade aos resultados de uma pesquisa qualitativa exploratória-descritiva, multicasos, sob a coordenação desta autora, que identificou e descreveu negócios sociais nos vinte e sete estados brasileiros. Nesta segunda fase, os objetivos foram: identificar até que ponto os negócios sociais são fonte de inovação e avaliar as possíveis relações entre características do empreendimento social e tipo de inovação implementada. A inovação social foi analisada na perspectiva de resultado, ou seja, soluções novas (produto, processo, mercado ou organizacional) com potencial de gerar valor socioambiental para uma comunidade. A régua e as categorias analíticas de geração de valor socioambiental elaboradas neste estudo permitiram classificar os negócios sociais em termos de sua lógica de atuação (maior ênfase no mercado ou ênfase no social). Como resultado, evidenciou-se que a maior parte dos empreendimentos sociais com lógica social demonstrou a preocupação de gerar valor socioambiental em diferentes dimensões, porém com foco num determinado local. Para isso, implementam inovações organizacionais em função da capacidade de fazer alianças e parcerias que possibilitem suprir uma falha de mercado. Por outro lado, os empreendimentos com ênfase no mercado indicaram ser mais inovadores, diversificando produtos, preços e canais de distribuição, com potencial de provocar a reconfiguração de seu segmento. É possível dizer que os negócios sociais têm papéis e contribuições diferentes na proposição de alternativas para um desenvolvimento sustentável: negócios sociais com uma forte orientação social tendem a priorizar uma ação local e buscam gerar valor socioambiental em diferentes dimensões. Sua contribuição é qualitativa com maior profundidade do impacto. No caso de negócios sociais com lógica de atuação de mercado, a contribuição é em termos de abrangência e, portanto, quantitativa e escalável. Dessa forma, a lógica de atuação social direciona impactos com maior profundidade que proporcionam o desenvolvimento local e a transformação social. Já a lógica de mercado tende a provocar impactos de maior abrangência em dimensões específicas do desenvolvimento sustentável. Por fim, pode-se dizer que há uma grande oportunidade para o desenvolvimento de empreendimentos sociais que conciliem geração de valor econômico com valor social e ambiental de forma unívoca, a fim de contribuir para diminuição da pobreza, mas, também, para a conservação da biodiversidade e o desenvolvimento de uma economia de baixo carbono e com menor uso de recursos (economia circular). 



\section{Abstract}

The emergence and expansion of social enterprises in different parts of the globe have made this phenomenon a focus of study in the administrative sciences, both to understand their empirical characteristics, and to model appropriate management tools. The present study aims to advance the field of studies on social enterprises and in particular the social dimension of innovation. It is hoped that this will fill in some gaps in the literature, such as: the blurred distinction between determinants and analytical dimensions of innovation; the paucity of studies that look through the lens of results; and the fact that most studies only conjoin social innovation with non-profits. To bridge these gaps, the following research problem was formulated: to what extent are social enterprise models environmental innovation generators? This study provides a continuation of the results of a multi-case, exploratory-descriptive qualitative research, under the coordination of this author, who identified and described social enterprises in all twenty-seven Brazilian states. In the second phase, the objectives were to identify the extent to which social businesses are a source of innovation and to evaluate possible relationships between social enterprise characteristics and type of innovation implemented. Social innovation was analyzed from the results perspective: i.e. new solutions (product, process, marketing, or organizational) potentially able to generate socioenvironmental value for a community. The value creation scale and analytical categories here developed allowed classification of social business in terms of its performance logic (greater emphasis on the market or greater emphasis on social). As a result, it became clear that most social enterprises with a social logic demonstrate a concern for generating different dimensions of socioenvironmental value, albeit focused on a particular location. To that end, they implement organizational innovations by dint of their ability to forge alliances and partnerships that make it possible to compensate for failure in the market. On the other hand, market-oriented enterprises were found to be more innovative, diversifying products, prices, and distribution channels, with the potential to cause the reconfiguration of their segment. One can say that social enterprises have different roles and contributions in proposing alternatives for sustainable development: those with a strong social orientation tend to prioritize local action and seek to generate social and environmental value in different dimensions. Their contribution is qualitative, with a greater depth of impact. In the case of social enterprise with a market performance logic, the contribution is in terms of scope, and thereby quantitative and scalable. Hence, the logic of social action directs greater depths of impact that provide local development and social transformation, whereas the market logic tends to cause a greater scope of impact in specific sustainable development dimensions. Finally, it can be said that there is a great opportunity for the development of social enterprises that unambiguously combine the generation of economic value with social and environmental value, in order to not only contribute to poverty reduction, but also to the conservation of biodiversity and the development of a low-carbon economy and a lower use of resources (circular economy). 



\section{Lista de Figuras}

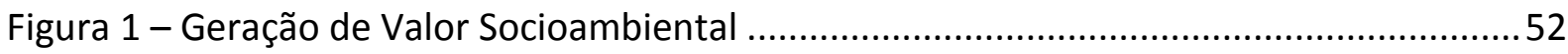

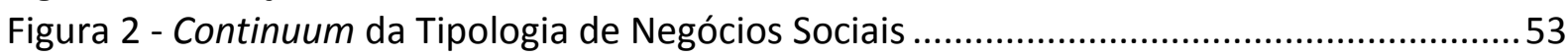

Figura 3 - Framework para Análise de Inovação Organizacional............................................61

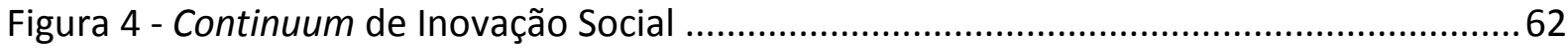

Figura 5 - Dimensões de Análise de Inovação Social ............................................................63

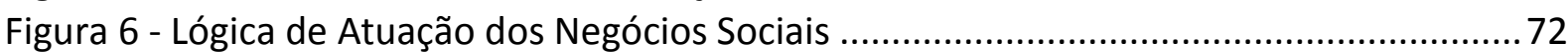

Figura 7 - Matriz Analítica sobre Tipos de Inovação ............................................................ 75

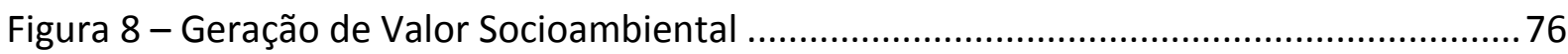

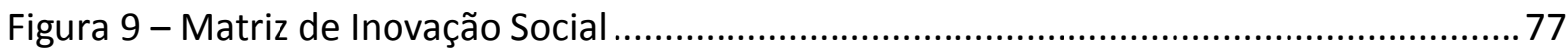

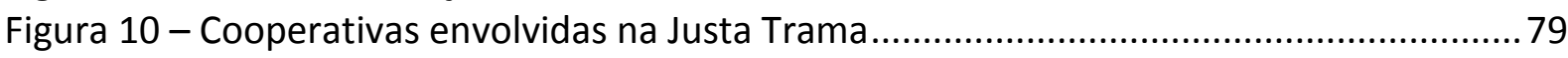

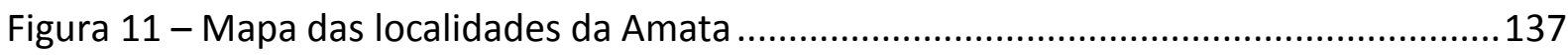

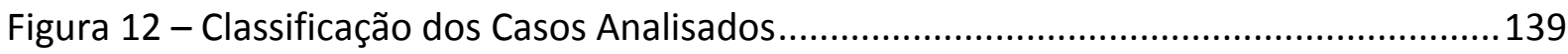

Figura 13 - Distribuição Geográfica dos Casos Analisados .................................................140

Figura 14 - Geração de Valor Socioambiental dos Casos Analisados ...................................141

Figura 15 - Tipo de Inovação implementada nos Casos Analisados .....................................144

Figura 16 - Tipo de Inovação e Posicionamento dos Negócios Sociais.................................145

Figura 17 - Profundidade e Abrangência da Inovação dos Casos Analisados ........................146

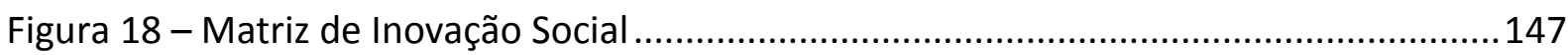





\section{Lista de Tabelas}

Tabela 1 - Indicações de Empreendimentos Sociais ...........................................................68

Tabela 2 - Workshops / grupos focais realizados ................................................................. 71

Tabela 3 - Fatores para Classificação dos Empreendimentos Sociais .................................... 73

Tabela 4 - Posicionamento do Empreendimento Social - Justa Trama ................................. 80

Tabela 5 - Posicionamento do Empreendimento Social - Meritt ........................................... 82

Tabela 6 - Posicionamento do Empreendimento Social - Terra Nova .................................... 84

Tabela 7 - Posicionamento do Empreendimento Social - Solar Ear ....................................... 89

Tabela 8 - Posicionamento do Empreendimento Social - Policlínica Granato........................ 91

Tabela 9 - Posicionamento do Empreendimento Social - Gerasol........................................ 93

Tabela 10 - Posicionamento do Empreendimento Social - Treebos....................................... 94

Tabela 11 - Posicionamento do Empreendimento Social - Ouro Verde ................................ 97

Tabela 12 - Posicionamento do Empreendimento Social - IPEC ............................................99

Tabela 13 - Posicionamento do Empreendimento Social - Você Aprende Agora ................101

Tabela 14 - Posicionamento do Empreendimento Social - BIOON ......................................103

Tabela 15 - Posicionamento do Empreendimento Social - INCORES ..................................... 105

Tabela 16 - Posicionamento do Empreendimento Social - Namastê ..................................... 107

Tabela 17 - Posicionamento do Empreendimento Social - AAPPE ....................................109

Tabela 18 - Posicionamento do Empreendimento Social - Bio Fair Trade ........................... 111

Tabela 19 - Posicionamento do Empreendimento Social - Fazenda Tamanduá ...................113

Tabela 20 - Posicionamento do Empreendimento Social - Rede Xique Xique ......................115

Tabela 21 - Posicionamento do Empreendimento Social - Banco Palmas ........................... 118

Tabela 22 - Posicionamento do Empreendimento Social - Cooperart-Poty .........................120

Tabela 23 - Posicionamento do Empreendimento Social - Fruta Sã..................................... 123

Tabela 24 - Posicionamento do Empreendimento Social - Ascampa .................................. 124

Tabela 25 - Posicionamento do Empreendimento Social - 100\% Amazônia ..........................127

Tabela 26 - Posicionamento do Empreendimento Social - Comaru ....................................128

Tabela 27 - Posicionamento do Empreendimento Social - Coofec's .................................... 130

Tabela 28 - Posicionamento do Empreendimento Social - Descarte Correto ........................133

Tabela 29 - Posicionamento do Empreendimento Social - ACS......................................... 135

Tabela 30 - Posicionamento do Empreendimento Social - Amata ......................................138

Tabela 31 - Categorias de Geração de Valor Socioambiental............................................... 142

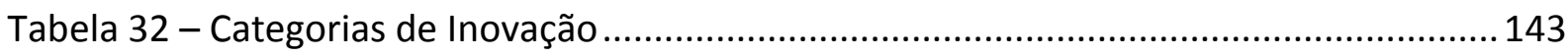





\section{Lista de Quadros}

Quadro 1 - Principais Elementos de Geração de Valor Social ................................................ 49

Quadro 2 - Indicadores Propostos - IRIS ........................................................................... 49

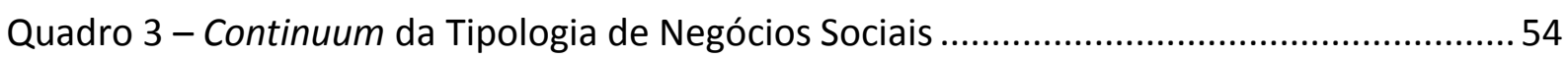

Quadro 4 - Definições de Inovação Social ........................................................................... 58 



\section{SUMÁRIO}

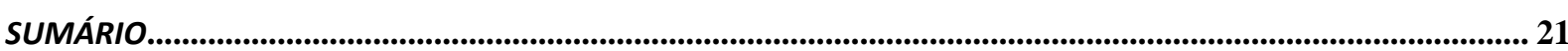

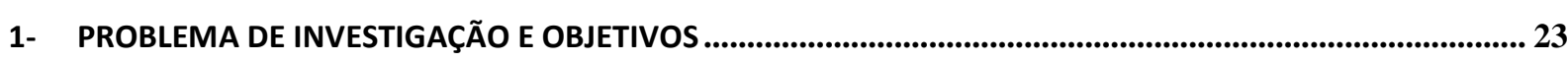

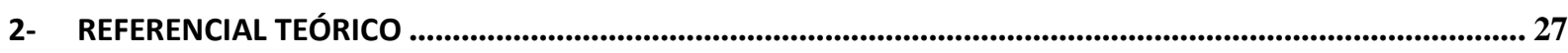

2.1 - O DESENVOLVIMENTO SUSTENTÁVEL EM PERSPECTIVA .............................................................................. 27

2.2 - A PERSPECTIVA DO EMPREENDEDORISMO SOCIAL ................................................................................ 31

2.3 - DIFERENTES CORRENTES SOBRE NEGÓCIOS SOCIAIS ............................................................................. 33

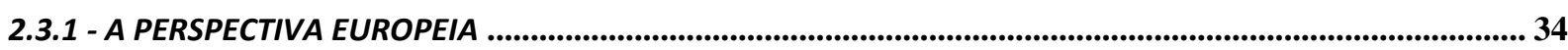

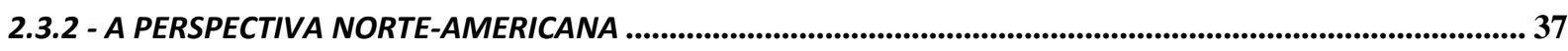

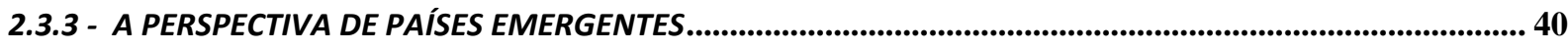

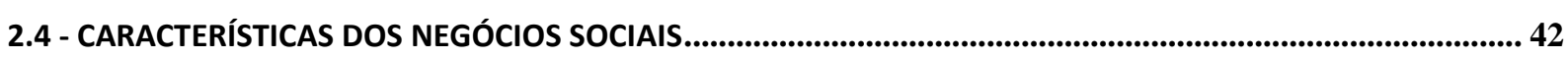

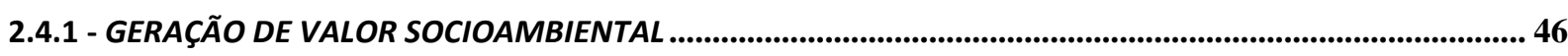

2.5 - QUADRO ANALÍTICO PARA COMPREENSÃO DOS NEGÓCIOS SOCIAIS ..................................................53

2.6 - INOVAÇÃO SOCIAL COMO UM CAMPO DE ESTUDO .................................................................................56

2.6.1 - RECORTE ANALÍTICO PARA O ESTUDO DE INOVAÇÃO SOCIAL .............................................................. 61

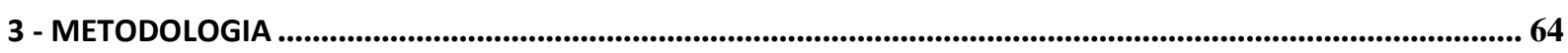

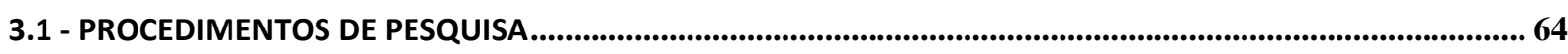

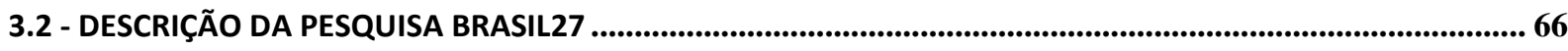

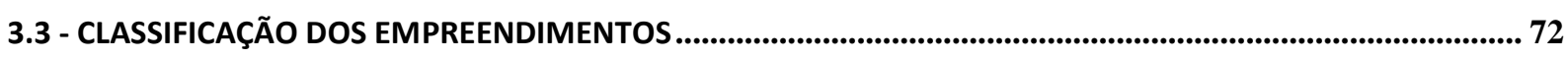

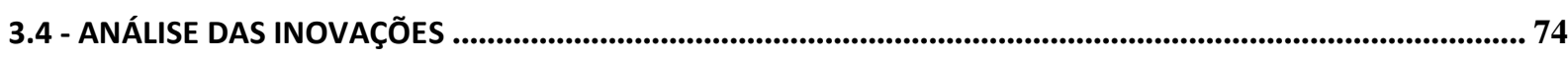

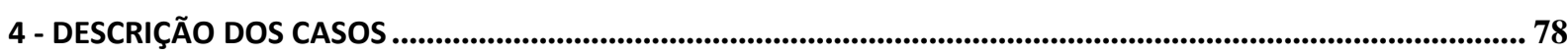

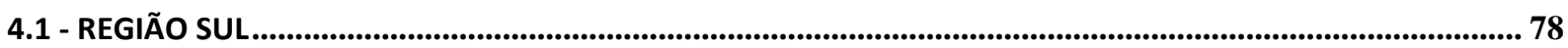

4.1.1 - JUSTA TRAMA (RS)......................................................................................................................... 78

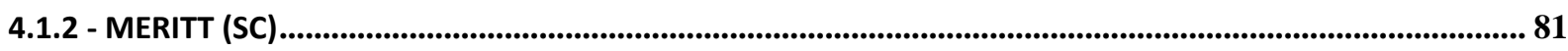

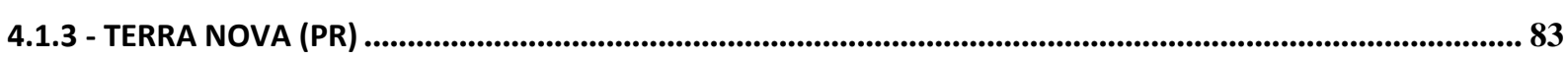

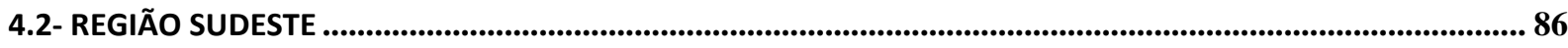

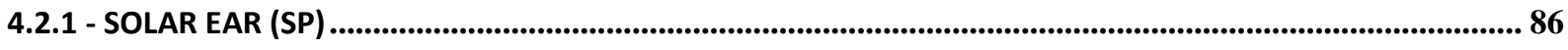

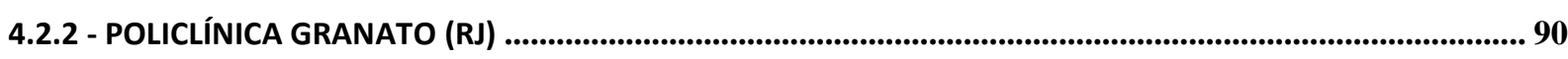

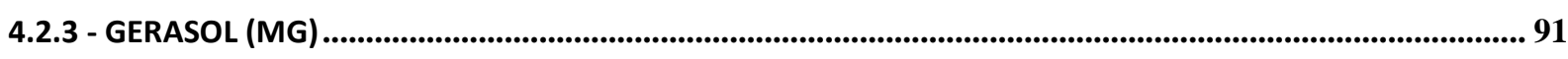

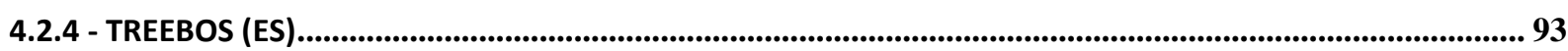

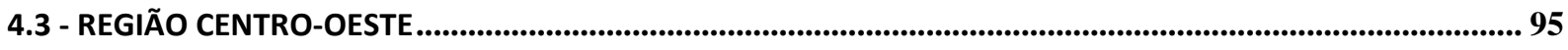

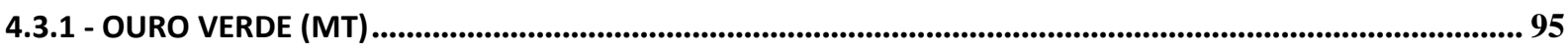

4.3.2 - INSTITUTO DE PERMACULTURA E ECOVILAS DO CERRADO - IPEC (GO) ...............................................98

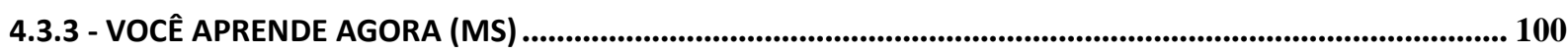

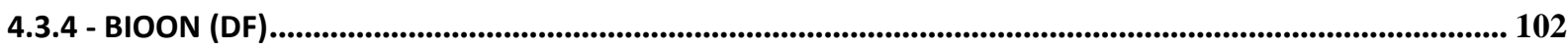

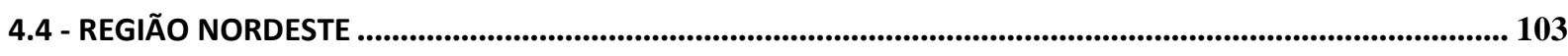

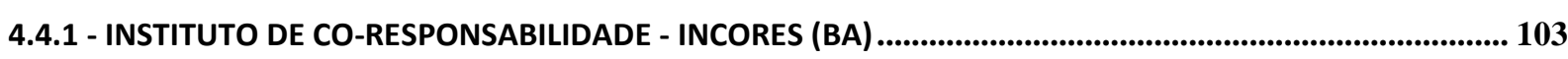




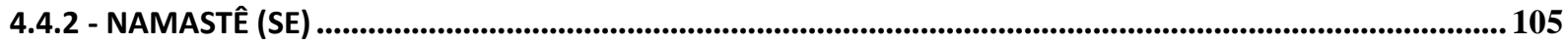

4.4.3 - ASSOCIAÇÃO DE AMIGOS E PAIS DE PESSOAS ESPECIAIS - AAPPE (AL) ........................................108

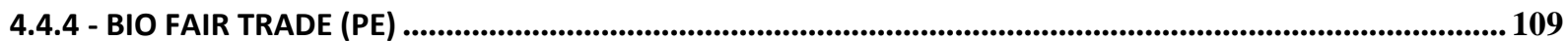

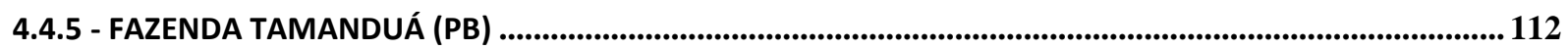

4.4.6 - REDE XIQUE XIQUE (RN) ............................................................................................................................. 114

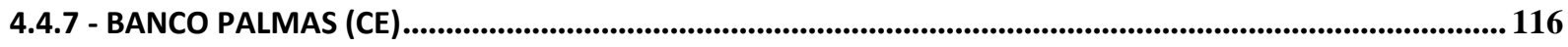

4.4.8 - COOPERATIVA DE ARTESANATO DE POTY VELHO - COOPERART-POTY (PI) ......................................119

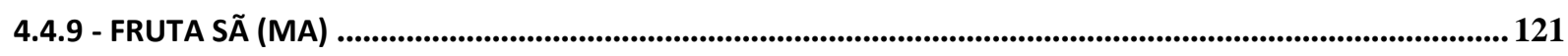

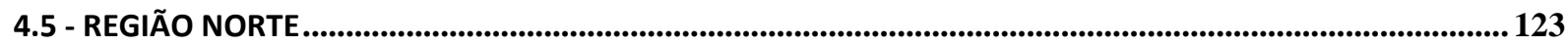

4.5.1 - ASSOCIAÇÃO DE CATADORES E CATADORAS DE MAT.RECICLÁVEIS DE PALMAS - ASCAMPA (TO)...... 123

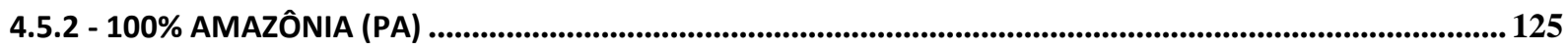

4.5.3 - COOPERATIVA MISTA DOS PRODUTORES E EXTRATIVISTAS DO RIO IRATAPURU - COMARU (AP)...... 127

4.5.4 - COOPERATIVA DE EMPREENDIMENTOS SOLIDÁRIOS DE BOA VISTA - COOFEC'S (RR) ....................... 129

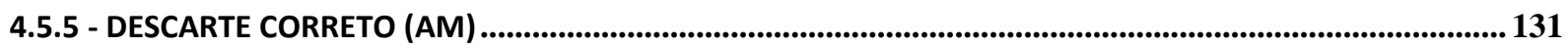

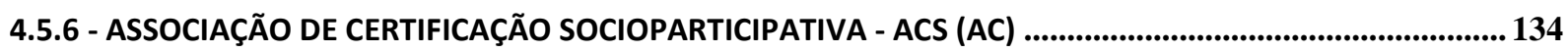

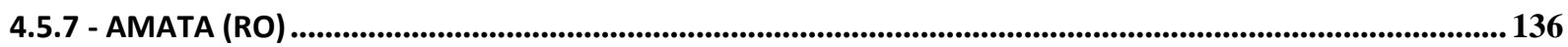

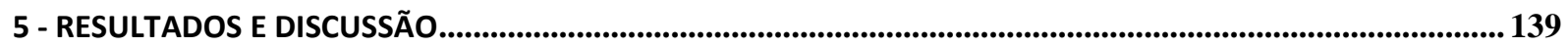

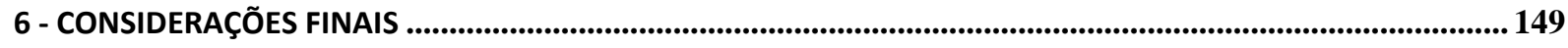

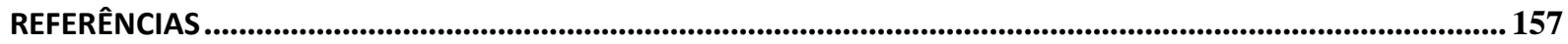

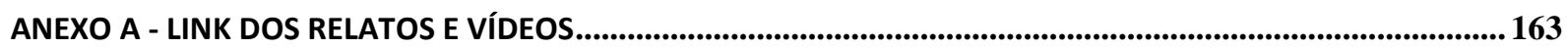

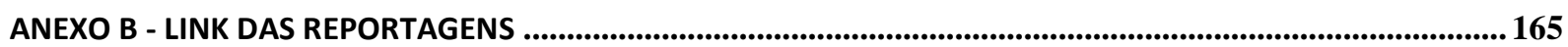




\section{1- Problema de Investigação e Objetivos}

Em países em desenvolvimento tem sido frequente o surgimento de alternativas para combater o alto déficit social e ambiental. Observa-se, desde a década de 1990, o crescimento de ações filantrópicas por parte de empresas privadas, bem como a intensificação do protagonismo de organizações da sociedade civil.

Passados quinze anos do século XXI, é possível observar uma forte aproximação entre empresas privadas, organizações do terceiro setor e instituições públicas. Estes atores reconheceram que a colaboração intersetorial é condição necessária para viabilizar um desenvolvimento sustentável.

Além do fenômeno de alianças intersetoriais, percebe-se uma tendência de revisão de valores nas organizações, particularmente em termos de maior consciência sobre o impacto que desejam provocar na sociedade e no meio ambiente. Como resultado, observa-se o surgimento de novos formatos organizacionais híbridos, que buscam atingir dois objetivos antes vistos como incompatíveis: sustentabilidade financeira e geração de valor socioambiental. Empresas sociais (social enterprise), negócios inclusivos (inclusive business), negócios sociais (social business), negócios com impacto social são alguns dos termos usados atualmente para explicar as organizações que visam a solução de problemas socioambientais com eficiência e a sustentabilidade financeira por meio de mecanismos de mercado.

Por ser uma terminologia nova, importada do ambiente empresarial, ela tem sido alvo de "calorosos" debates entre acadêmicos e practitioners. A tensão é provocada pela falta de um entendimento comum sobre um conceito novo e que procura conciliar dois temas vistos a priori como irreconciliáveis: negócios e impacto social. A falta de uma visão homogênea é explicada por dois principais fatores: pelas diferentes formas de definir o caráter social dos empreendimentos e pelas diversas maneiras de avaliar o caráter inovador deste tipo de organização. Nesse amplo espectro de atores, as configurações destes negócios assumem diferentes formatos. Cada organização vai se posicionar de acordo com os seus objetivos e interesses, dando um peso diferente para cada um dos fatores que compõem o conceito. 
A rede Social Enterprise Knowledge Network $\left(\mathrm{SEKN}^{1}\right)$, da qual o Centro de Empreendedorismo Social e Administração em Terceiro Setor (CEATS) faz parte, vem se dedicando, desde sua criação em 2001, ao estudo de empreendimentos sociais que podem provocar uma transformação socioambiental e contribuir para um desenvolvimento sustentável. De 2006 a 2010, foram realizados estudos comparativos de iniciativas de inclusão da população de baixa renda por meio de soluções de mercado. Os estudos demonstraram que apenas a inclusão na sociedade de consumo pode não ser suficiente para a promoção do desenvolvimento local sustentável de comunidades de baixa renda. Mais do que isso, os resultados enfatizaram que a participação dessa parcela da população nas cadeias produtivas como parceiros, fornecedores e empreendedores pode ser a solução mais efetiva para a geração de valor econômico e social. A concepção de modelos de negócios inclusivos é, portanto, uma necessidade. A pergunta que se coloca é: até que ponto os negócios sociais estão contribuindo para a promoção de um desenvolvimento sustentável a partir de modelos de negócios inovadores?

Este estudo constitui-se como uma pesquisa exploratória-descritiva e tem o objetivo geral de analisar a relação entre inovação social e negócios sociais. Os objetivos específicos são:

- Desenvolver um referencial que permita classificar os diferentes tipos de negócios sociais;

- Definir categorias temáticas que permitam mapear as contribuições dos negócios sociais em termos de valor socioambiental;

- Aproximar o debate sobre inovação social à luz de referências de inovação e de organizações híbridas;

- Comparar modelos de negócios sociais de todas as regiões do Brasil;

- Estabelecer as diferenças entre geração de valor socioambiental e inovação social;

- Identificar características e padrões que ajudem a formular hipóteses sobre inovação social e negócios sociais.

\footnotetext{
${ }^{1}$ As universidades que integram o SEKN são: a EGADE - Escola de Graduados em Administração e Direção de Empresas, do Instituto Tecnológico Monterrey; o INCAE - Instituto Centro-americano de Administração de Empresas em Alajuela (Costa Rica); a Universidade de Los Andes (Colômbia); a Pontifícia Universidade Católica do Chile; a Universidade de San Andrés, na Argentina; a ESADE (Escola Superior de Administração e Direção de Empresas), da Espanha; o IESA (Instituto de Estudos Superiores de Administração), da Venezuela; a Universidade do Pacífico, do Peru; e a Universidade de São Paulo por meio do CEATS (Centro de Empreendedorismo Social e Administração em Terceiro Setor da Faculdade de Economia, Administração e Contabilidade)
} 
Trata-se de uma continuidade aos resultados de uma pesquisa exploratória anterior, denominada Brasil $27^{2}$, cujos objetivos foram identificar e descrever empreendimentos existentes nos 27 estados brasileiros que pudessem ser caracterizados como negócios sociais.

A emergência e expansão de negócios sociais em diferentes partes do globo faz com que este fenômeno seja foco de estudo das ciências administrativas, tanto para conhecer suas características empíricas quanto para estender-lhe os conhecimentos provenientes da teoria das organizações e as possibilidades de modelar ferramentas apropriadas de gestão. É preciso ressaltar, contudo, que o estudo do fenômeno do empreendedorismo social não deve restringir-se às áreas específicas da Administração, da Teoria das Organizações e da Gestão Organizacional. Ele deve ser contemplado por meio de uma abordagem multidisciplinar em função das interfaces que apresenta com as áreas da Sociologia, da Política e da Economia, especialmente no enfoque ao desafio do desenvolvimento socioeconômico e ambiental.

Este trabalho busca suprir lacunas no campo teórico de administração, particularmente sobre a configuração de modelos inovadores de negócios sociais e a geração de valor socioambiental. No espaço empírico da pesquisa realizada e das análises avançadas por este estudo, a intenção é apoiar a geração e a consolidação de negócios sociais, bem como de investimentos voltados para estimular iniciativas que visam provocar impacto socioambiental. Por fim, é esperado que as reflexões aqui elaboradas possam contribuir para a compreensão dos limites e das potencialidades dos negócios sociais a fim de promover o desenvolvimento sustentável com soluções inovadoras, sejam elas de caráter incremental, sejam elas capazes de provocar rupturas que provoquem mudanças sociais transformadoras.

\footnotetext{
${ }^{2}$ A pesquisa Brasil 27 foi desenvolvida no período de março de 2013 a maio de 2014 pelo Centro de Empreendedorismo Social e Administração em Terceiro Setor (CEATS) sob a coordenação das Profas. Dras. Graziella Maria Comini e Rosa Maria Fischer. Recebeu financiamento internacional da Rockefeller Foundation, Omidyar, Fundação Avina e apoio do Instituto de Cidadania Empresarial.
} 


\section{2- Referencial Teórico}

\section{1 - O Desenvolvimento Sustentável em Perspectiva}

Ainda que os indicadores tradicionais de mensuração da pobreza demonstrem a redução quantitativa do segmento de miseráveis na população brasileira, o quadro de exclusão social continua preocupante (FISCHER; COMINI, 2012). A desigualdade na distribuição de renda e demais fatores condicionantes continuam restringindo o acesso de milhões de pessoas aos direitos de cidadania. Acrescida à situação de pobreza, há também uma crise ambiental, como aponta o Relatório The Economics of Ecosystems and Biodiversity for national and international Policy Makers (TEEB): “We are running down our natural capital stock without understand the value of what we are losing (TEEB, 2009, p.4).

De acordo com relatório do Millennium Ecosystem Assessment (MEA, 2005) ${ }^{3}$, a ação do homem está alterando, de forma irreversível e acelerada, a diversidade de vida na Terra, ocasionando uma perda de biodiversidade. Projeções e cenários indicam que estas taxas vão continuar, ou acelerar, no futuro. Os principais fatores diretos que levam a perda de biodiversidade e de serviços ecossistêmicos ${ }^{4}$ são: a alteração dos habitats (tais como alta exploração dos solos, modificação física dos rios ou retirada de água dos rios, perda de recifes de coral devido à pesca de arrasto), mudanças climáticas, espécies exóticas invasoras e a poluição.

Especialistas que participaram da elaboração do relatório TEEB (2009) - apontam que a crise ambiental que sofremos hoje é resultante de um crescimento econômico desordenado, que nunca se preocupou em mensurar o valor da natureza e dos serviços ecossistêmicos para o bem-estar humano. Este cenário, que pouco ou nada se altera com o passar do tempo, tem colocado a todos que se inquietam com o quadro de desigualdades e degradação ambiental o desafio de buscar caminhos que promovam o desenvolvimento.

\footnotetext{
${ }^{3}$ O MEA é uma iniciativa da Organização das Nações Unidas - ONU, criada em 2001, com o envolvimento de mais de 1300 especialistas internacionais. O objetivo do projeto foi avaliar as consequências das alterações dos ecossistemas para o bemestar humano e de gerar conhecimento científico para melhorar a conservação e o uso sustentável dos ecossistemas. Em 2005, foi publicado o referido relatório com os principais resultados e recomendações.

${ }^{4}$ Ecossistema é definido pela Convenção sobre Diversidade Biológica (CBD, 1992,p.1) como "um complexo dinâmico de comunidades vegetais, animais e de microrganismos e o seu meio inorgânico que interagem como uma unidade funcional" e serviços ecossistêmicos "são os benefícios que as pessoas obtêm dos ecossistemas" (MEA, 2005, p. 57)
} 
Esta realidade mundial também é vivenciada no Brasil. Durante as décadas de 1960 e 1970, o desenvolvimento era sinônimo de crescimento urbano-industrial, focado em metas macroeconômicas, porém muitas vezes desvinculadas das necessidades sociais e ambientais específicas de cada localidade e de sua população. O conjunto da realidade brasileira era concebido como um todo homogêneo, cujo desenvolvimento seria alavancado por meio do crescimento das atividades industriais, do consumo urbano e da modernização de hábitos e costumes. Porém, sem se preocupar com a inclusão de população marginalizada e, muito menos, com o estoque de capital natural.

As sequelas dessa visão limitada ficaram patentes em indicadores sociais e ambientais que permitiram a elaboração da famosa metáfora dos dois países contraditórios. Nos anos 1980, a conjuntura recessiva da economia internacional aprofundou a desigualdade que sempre caracterizou as relações sociais no Brasil. Em oposição à proposta de crescimento econômico-industrial acelerado, o conceito de desenvolvimento começa, então, a ser definido com uma abrangência ampliada, qualificada pela noção de sustentabilidade.

Cunhado originalmente com o objetivo de preservação do meio ambiente, o qualificativo de sustentabilidade esboçou-se, em seguida, como um construto de maior complexidade, porque passou a abranger, concomitantemente, ampla gama de componentes da vida social. Em outras palavras, o desenvolvimento deixa de ser sinônimo de crescimento de alguns setores modernos da economia para se transformar em uma proposta de aperfeiçoamento contínuo dos múltiplos fatores que influenciam o bem-estar humano e as condições de vida e de sociabilidade das pessoas (FISCHER; COMINI, 2012).

A sustentabilidade pressupõe múltiplos conjuntos de forças sociais, econômicas e políticas articuladas de forma a obter melhorias simultâneas: no equilíbrio da distribuição da renda, no padrão de qualidade de vida das populações, no acesso aos direitos civis e aos serviços públicos para os cidadãos, na garantia de preservação e de efetivas condições de reprodução dos recursos naturais.

Nessa proposição, os fatores econômicos não são hierarquizados de maneira a determinar os demais componentes do cenário social. Tampouco o crescimento industrial é considerado o elemento determinante do desenvolvimento dos demais aspectos da vida em sociedade. A evolução do desenvolvimento não é proposta como um caminho linear, no qual a acumulação de riqueza, em um setor da economia ou em uma classe social, era considerada 
um pré-requisito para uma distribuição posterior que, supostamente, alavancaria os demais setores e segmentos sociais. A sustentabilidade define que os padrões de desenvolvimento devem ser estabelecidos a partir dos componentes múltiplos e específicos de cada realidade: a oferta existente de recursos humanos, naturais e materiais; as vocações para a produção econômica, delineadas pelas condições físico-geográficas e histórico-culturais próprias de cada região; as demandas e necessidades, assim como as potencialidades e experiências desenvolvidas.

Esta visão passou a ser incorporada e difundida por diversas fontes. Sen (2000) afirmava que o crescimento e a produtividade estavam vinculados a investimentos nas áreas sociais, pois existe uma interdependência entre o desenvolvimento humano, a geração e a expansão de competências sob a forma de capacidades produtivas.

\footnotetext{
"Existe uma acentuada complementaridade entre a condição de agente individual e as disposições sociais: é importante o reconhecimento simultâneo da centralidade da liberdade individual e da força das influências sociais sobre o grau e o alcance da liberdade individual. Para combater os problemas que enfrentamos, temos de considerar a liberdade individual um comportamento social. O desenvolvimento consiste na eliminação das privações de liberdade que limitam as escolhas e as oportunidades das pessoas de exercer ponderadamente sua condição de agente (SEN, 2000, p. 10)
}

Quando se amplia a noção de capital, abrangendo os diversos tipos de ativos que constituem o patrimônio de um povo, ressalta a observação de que a abrangência e a complexidade da proposição do desenvolvimento sustentável demandam um pré-requisito essencial: o acesso da sociedade às condições plenas de participação e aos meios de comunicação e intercâmbio (OSTROM, 1999). A sustentabilidade do desenvolvimento é um processo, isto é, mantém-se no movimento contínuo da dinâmica social. Por isso, deve continuamente ser alimentado pelos insumos da demanda e da realização das pessoas e dos grupos sociais. Isso pressupõe que essas pessoas e grupos tenham condições de manifestar-se, tenham canais para obter e trocar informações, saibam acessar os meios para se articularem e se comunicarem e estejam capacitadas a utilizarem os dados obtidos, ou seja, é fundamental aumentar o capital social.

As perspectivas do desenvolvimento sustentável orientam-se, portanto, para assegurar, prioritariamente, a qualidade de vida das pessoas, a preservação dos recursos naturais para as futuras gerações, bem como a justiça social na distribuição e na fruição dos bens criados pela humanidade. Esses padrões de desenvolvimento podem e devem estar parametrizados 
pelos condicionantes da conjuntura econômico-social. O desenvolvimento sustentável exige que empresários, profissionais e trabalhadores assumam seu papel ativo no exercício da responsabilidade social, tanto no cotidiano da vida pessoal como nos espaços organizacionais. 


\section{2 - A Perspectiva do Empreendedorismo Social}

O vocábulo empreendedor tem sido empregado de forma reducionista na literatura de Economia e Administração. É usado, costumeiramente, para identificar pessoas com capacidade de criar negócios, normalmente configurados nos moldes organizacionais da empresa capitalista de propriedade privada com a premissa de maximização de lucro aos acionistas. Entretanto, seu significado é mais amplo. Dees (2001) enfatiza que o empreendedor do século XX e XXI deve ser, em sua essência, um agente de mudança e fomentador de transformação social.

Adotando-se essa concepção mais abrangente, pode-se compreender a atuação do empreendedor em diferentes âmbitos organizacionais, incluindo organizações sem fins lucrativos, associações de caráter cooperativo, empreendimentos com finalidades sociais e ambientais, bem como iniciativas socioambientais de empresas privadas e de órgãos públicos. Ou seja, o perfil de competências e habilidades de um indivíduo empreendedor pode realizar sua vocação nos mais diversos ambientes organizacionais. O que diferencia o empreendedor social é o foco de sua ação nas mudanças sociais, sendo a riqueza apenas um meio para determinado fim (DEES, 2001).

Nesse mesmo sentido, Drucker (1987) ressalta que os elementos próprios da ação empreendedora - visão estratégica, inovação, senso de oportunidade, eficiência de gestão, efetividade de resultados - constituem os componentes essenciais ao empreendedorismo social.

Diferentemente dos movimentos sociais, caracterizados pela espontaneidade e relativa informalidade, os empreendimentos sociais são organizações formalmente constituídas, responsabilizam-se por sua autonomia administrativo-financeira e, ainda que com algumas especificidades, inserem-se nas relações de mercado. Exigem uma gestão cuidadosa para resguardarem-se de sua vulnerabilidade financeira e para serem suficientemente transparentes a fim de assegurar sua legitimidade junto aos públicos com os quais interagem.

Muitos empreendimentos são oriundos de organizações da sociedade civil que amadureceram seu desempenho. Frente ao desafio de assegurar a sustentabilidade e 
independência financeira, elas criaram formas de geração de receita a partir dos serviços que prestam e dos bens que são capazes de produzir. Outros surgiram da atuação social empresarial, por exemplo, como um avanço em relação aos projetos e parcerias que caracterizavam os programas de responsabilidade corporativa. Há também a criação ou recriação de novos negócios destinados a incorporar aqueles segmentos sociais até então excluídos do consumo.

No entanto, é significativa a emergência de empreendimentos que não estão vinculados às raízes dos movimentos sociais e das organizações do terceiro setor, tampouco às iniciativas empresariais de responsabilidade social. São empreendimentos que surgem, desde sua concepção, como "qualquer iniciativa que gere valor social como principal objetivo estratégico e direciona sua ação de forma inovadora" (NICHOLLS, 2006, p.3). Isto é, são propostas de negócios sociais que visam atender, com serviços básicos - como nas áreas de educação e saúde -, a população que não tem acesso à oferta privada de altos preços nem à oferta pública que é escassa e de má qualidade. Outros são associações dedicadas à produção econômica para gerar trabalho e renda para pessoas e grupos que têm dificuldades de acesso aos mercados formais. Há ainda empreendimentos voltados ao meio ambiente, que realizam ações de preservação dos recursos naturais, transações por emissão de carbono, programas educacionais e certificações ambientais.

Ou seja, é uma ampla e diversificada gama de organizações, com diferentes portes, inseridas ou não em cadeias produtivas, pertencentes ou não a arranjos produtivos locais, que estão ocupando espaços para incrementar a vitalidade nas relações econômicas e a participação nas relações sociais e políticas. Nesta multiplicidade de possibilidades, é possível também observar o surgimento de um novo tipo de organização que aglutina dois objetivos antes vistos como incompatíveis: a geração de valor econômico e a geração de valor social. Empresas sociais (social enterprise), negócios inclusivos (inclusive business) e negócios sociais (social business) são alguns dos termos usados atualmente para explicar as organizações que visam solucionar problemas sociais com eficiência e sustentabilidade financeira por meio de mecanismos de mercado. Como aponta Young (2008), apesar da ambiguidade e diversidade dos termos, pode-se afirmar que este tipo de empreendimento é visto como algo importante e distinto da forma clássica e tradicional de fazer negócios. 


\section{3 - Diferentes Correntes sobre Negócios Sociais}

Pode-se encontrar na literatura três principais correntes que explicam os negócios sociais. A perspectiva europeia, nascida da tradição de economia social (associativismo e cooperativismo), enfatiza a atuação de organizações da sociedade civil com funções públicas. A perspectiva norte-americana, para a qual esses negócios são organizações privadas com lógica de mercado dedicadas a soluções de problemas socioambientais. A terceira perspectiva, predominante em países em desenvolvimento, considera negócios sociais como empreendimentos socioambientais que atuam na lógica de mercado e que visam a redução da pobreza e a transformação das condições sociais que marginalizam ou excluem as pessoas.

Ao analisar as diferentes definições de negócios sociais propostas na literatura internacional, desde as utilizadas por organizações aceleradoras de negócios sociais (organizações que tem como objetivo facilitar e acelerar o amadurecimento e consolidação de empreendimentos sociais) até as propostas por investidores em negócios sociais/inclusivos (instituições que alocam recursos nacionais ou internacionais de indivíduos ou de corporações para investir em negócios cujo objetivo seja a solução de problemas sociais), é possível traçar uma régua que possibilita visualizar definições que estão mais próximas da lógica de mercado e outras em que há predominância da lógica social. Da mesma forma que Austin (2002) propôs um continuum para avaliar as alianças e parcerias intersetoriais, pode-se dizer que também há um continuum na tipologia de negócios sociais, conforme será apresentado no final deste capítulo. 


\subsection{1 - A Perspectiva Europeia}

Na Europa, o termo empresa social está bem mais difundido, sendo inclusive reconhecido como um formato jurídico na maioria dos países. O processo de formação das empresas sociais na Europa teve como motivação inicial oferecer, a menor custo, serviços que estão, originalmente, no escopo de atuação do setor público, assim como gerar oportunidades de trabalho para populações marginalizadas desempregadas (BORZAGA; DEFOURNY, 2001). De uma maneira geral, pode-se dizer que há muita similaridade às organizações sociais brasileiras (OS), previstas na Reforma de Estado no Brasil implementada a partir da década de 1990.

De acordo com a definição da rede de pesquisadores Emergence of Social Enterprise in Europe (EMES) as empresas sociais são organizações com o objetivo explícito de beneficiar a comunidade. Iniciadas por um grupo de cidadãos, o interesse material dos investidores capitalistas nessas organizações é sujeito a limites (EMES, 2016).

A abordagem acadêmica predominante na Europa ressalta a importância da participação dos beneficiários na tomada de decisão, bem como o reinvestimento do lucro na própria organização para potencializar seu crescimento e impacto social. Esta visão tem como premissa a existência de uma tensão entre maximização de retorno financeiro e maximização do impacto social.

Segundo Travaglini, Bandini e Mancione (2009), na Europa, é possível agrupar três categorias de atuação das empresas sociais: (i) empresas de integração ao trabalho, as Work Integration Social Enterprise (WISE); (ii) empresas cujo objetivo social primordial é produzir produtos e serviços com alvo social ou conduzido por interesse coletivo (iii) empresas que favorecem o desenvolvimento social e econômico local pela promoção de participação de cidadãos e governo local nas atividades. Apesar de constar como uma opção jurídica na maioria dos países europeus, os formatos legais diferem entre eles. Para os autores, fazem parte do grupo de empresas sociais companhias limitadas com garantia, indústrias, sociedade de previdência e por ações. Corroborando com essa visão, a Organization for Economic Co-operation and Development (OECD, 1999) define empresas sociais como sendo organizações que buscam, com espírito empreendedor, metas sociais e econômicas capazes 
de trazer soluções inovadoras para problemas de exclusão social e desemprego. Seu propósito principal é diferente da maximização do lucro.

Já para Social Enterprise Coalition (2003), as empresas sociais são negócios comerciais com propósitos sociais e ambientais. Ainda que os objetivos de muitos negócios comerciais possam ser considerados como sociais, as empresas sociais são distintas, pois seu propósito social e ambiental é absolutamente central àquilo que ela faz. Os lucros são reinvestidos para dar suporte e levar adiante a missão deles para uma mudança positiva. Nesse sentido, pode-se dizer que a intencionalidade faz toda diferença.

Uma definição amplamente utilizada por organizações na Europa e criada pelo Departamento de Comércio e da Indústria do governo do Reino Unido (DTI, 2012) afirma que:

\footnotetext{
"as empresas sociais são negócios com objetivos sociais primordiais nos quais a receita gerada é reinvestida principalmente para os propósitos do negócio ou na comunidade, em vez de serem destinados à necessidade de maximização de lucro dos acionistas e proprietários." (DTI, 2012, p. 13, tradução nossa)
}

Segundo Travaglini et al. (2009), as empresas sociais possuem as seguintes características:

(i) orientação para negócios - elas estão diretamente envolvidas na fabricação de produtos e na prestação de serviços para o mercado;

(ii) orientação para causa social - elas têm causas sociais ou ambientais explicitas tais como a criação de emprego, treinamento etc., e seus lucros são reinvestidos para atingir seus objetivos sociais;

(iii) propriedade social ("social ownership")--. elas são organizações autônomas, sua governança e estrutura de propriedade são baseadas na participação direta de grupos de stakeholders (isto é, empregados, usuários, clientes, grupo de comunidade local e investidores sociais), ou de administradores ou diretores que controlam a empresa com o objetivo de atender um grupo vasto de stakeholders. Elas são transparentes para com seus stakeholders e para com a comunidade por meio do impacto social, ambiental e econômico que trazem. Quanto à distribuição de lucros, os autores afirmam que algumas dessas empresas acabam por distribuir os lucros como cotas para os stakeholders, ou ainda usam-nos para o benefício da comunidade, mas sempre com propósito de promover a integração econômica e social de pessoas não favorecidas. 
O modelo de governança é um dos pontos de maior relevância na definição das empresas sociais europeias. Esse aspecto decorre das tradições de associativismo no continente. Segundo Graziano (1993), o pluralismo moderno é o pluralismo da associação voluntária baseada na livre participação de seus membros. A existência de tais grupos é uma consequência da Europa pós-revolucionária (Revolução Francesa), mais exatamente uma reação à concepção liberal de Estado e ao seu princípio fundador, a soberania nacional "une et indivisible".

Assim, a lógica de tomada de decisão dos negócios sociais no modelo europeu pressupõe um processo participativo e transparente. Além disso, também pela questão de tradição e cultura, os negócios sociais na Europa engajam-se em prover serviços sociais e serviços de integração ao trabalho para comunidades e grupos desfavorecidos, em áreas urbanas ou rurais. Prestam, ainda, serviços para a comunidade, principalmente na área educacional, cultural e ambiental.

Nesse sentido, é possível observar uma tendência no modelo europeu de valorização do coletivo, participação na tomada de decisão de todos stakeholders envolvidos e, ainda, a transparência na gestão. Essa dimensão coletiva e participativa faria com que houvesse "redução de comportamentos oportunistas isolados gerando uma estrutura de governança" (GALERA; BORZAGA, 2009, p. 213, tradução nossa). Assim, no modelo europeu, além de possuírem um propósito social, as organizações devem ter a atribuição de direitos de propriedade e poder de controle de outras partes interessadas, não apenas dos investidores, acoplado a um modelo de governança aberta e participativa (GALERA; BORZAGA, 2009). 


\subsection{2 - A Perspectiva Norte-Americana}

Diferentemente da Europa, nos Estados Unidos o termo mais predominante é iniciativa social (social venture). Muitas vezes, é utilizado para definir uma empresa que tenha objetivo social, como na Europa, ou de uma unidade de negócio inserida em uma empresa tradicional. Além disso, o termo foi apropriado por organizações sem fins lucrativos que decidiram atuar no mercado por meio da venda de bens e serviços.

Esta multiplicidade de utilização do termo é explicada pela observação de duas discussões, acadêmicas e práticas, concomitantes em meados dos anos 1990 naquele país: uma delas advinda a partir do contexto corporativo e outra do contexto de empreendimentos sociais. No primeiro caso, houve o questionamento em relação às estratégias comerciais adotas pelas multinacionais as quais estariam negligenciando um número elevado de potenciais consumidores classificados como base da pirâmide. Autores como Prahalad \& Hart (2002) foram pioneiros no destaque do importante papel que as multinacionais deveriam ter na mitigação de problemas socioambientais. Os autores apontaram que as ações de responsabilidade social corporativa seriam limitadas e, em alguns casos, ineficazes para contribuir para melhoria das condições de vida das pessoas marginalizadas. A principal contribuição das empresas multinacionais seria oferecer serviços e produtos inovadores e que atendessem uma demanda bem diferente daquela que constituía o tradicional foco das grandes corporações. .

Concomitante a este debate, no contexto dos empreendedores sociais, houve um questionamento sobre a limitação da capacidade de obtenção de recursos por meio de doações, em parte explicado pela retração do financiamento estatal, iniciado no fim dos anos 1970 (KERLIN, 2006, p. 251). Nesse sentido, alguns empreendedores sociais defendiam que haveria espaço para organizações sem fins lucrativos atuarem no mercado, por meio da oferta de bens e serviços, e serem inovadoras no alcance de resultados sociais.

Segundo Young (2008, p. 35), as iniciativas de mercado com objetivos sociais podem ser analisadas por várias lentes disciplinares diferentes. Nesse sentido, o autor apresenta uma multiplicidade de possibilidades de formatos, desde iniciativas ligadas à responsabilidade 
social empresarial ou marketing de grandes corporações até instituições criadas exclusivamente para perseguir a geração de valor social, a saber:

(i) filantropia corporativa: organização com fins lucrativos que dedica uma parcela dos seus recursos para programas sociais, como parte da sua estratégia competitiva;

(ii) empresa com fim social: organização com uma missão social, que opera no mercado de maneira a realizar sua missão de forma mais eficaz;

(iii) híbrido: organização com duplo objetivo de ganhar dinheiro para seus participantes e endereçar objetivos sociais definidos;

(iv) projeto de geração de recursos: atividade da organização voltada exclusivamente para gerar receita para a organização;

(v) projeto de finalidade social: atividade de uma organização destinada exclusivamente a endereçar uma missão social ou objetivos sociais selecionados;

(vi) projeto híbrido: atividade de uma organização direcionada tanto para produção de receita quanto para contribuir para a missão ou objetivos sociais da organização.

Assim, sob a perspectiva norte-americana, o conceito de empresa social inclui qualquer ação empreendedora de mercado que tenha impacto social com sua ação comercial. Podem assumir diferentes formatos legais, sociedades anônimas, corporações, companhias limitadas e organizações sem fins lucrativos (KERLIN, 2006).

Em 2008, foi aprovada nos Estados Unidos uma nova forma jurídica de organização, a L3C ou low-profit, limited liability company que é uma empresa híbrida entre sem fins lucrativos e uma empresa por lucro. Esse formato jurídico coloca como principal objetivo o fator social e em segundo plano a preocupação com o lucro, entretanto, existe a possibilidade para distribuir lucros, depois dos impostos, aos proprietários ou investidores. Dados apresentados por Cooney et al. (2014) mostram que a L3C apresentou um crescimento acelerado no período de 2008 e 2012 em função da aprovação feita em 10 estados americanos ${ }^{5}$.

Outro formato jurídico criado nos Estados Unidos é a Benefit Corporation, criada, em 2010, nos estados de Maryland e Vermont e atualmente presente em mais de 20 estados

\footnotetext{
${ }^{5}$ Em 2013, Carolina do Norte reviu sua legislação e não permitiu mais criar L3C.
} 
americanos (COONEY et al., 2014). Diferentemente da L3C, a Benefit Corporation não tem limitação de distribuição de lucro. É uma corporação criada para gerar lucro e impacto positivo na sociedade por meio de atividades que promovam a combinação de um benefício público específico. Uma Benefit Corporation deve incluir um dos seguintes serviços públicos específicos: (i) fornecer produtos benéficos ou serviços a indivíduos ou comunidades; (ii) promover oportunidades econômicas para os indivíduos ou comunidades que deve ir além da criação de postos de trabalho no curso normal da criação de um negócio; (iii) preservar o meio ambiente; (iv) melhorar a saúde humana; ( $v$ ) promover as artes, as ciências, ou avanço do conhecimento; (vi) aumentar o fluxo de capital a entidades com fins de utilidade pública, ou (vii) a realização de qualquer outro benefício especial para a sociedade ou para o meioambiente (B-LAB, 2016) ${ }^{6}$.

Até julho de 2014, foram contabilizadas 998 Benefit Corporations e 1051 L3C (COONEY et al., 2014). No entanto, os autores apontam uma tendência de aceleração das Benefit Corporations, levando em conta sua aprovação em mais estados americanos. Apenas em quatro estados americanos os dois formatos jurídicos são permitidos (Vermont, Illinois, Louisiana e Rhode Island).

Tomando como base o exemplo da regulamentação L3C e Benefit Corporation, é possível observar que a abordagem americana foge da dependência do financiador público estatal para a existência das iniciativas de empresas sociais. Além disso, ressalta a figura do proprietário ou empreendedor, isto é, o indivíduo como responsável pela geração do impacto social positivo por meio de uma iniciativa de mercado, competindo como qualquer outra empresa por lucros.

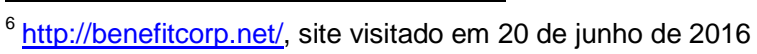




\subsection{3 - A Perspectiva de Países Emergentes}

Diferentemente da Europa em que há predominância do termo empresa social (social enterprise) e nos Estados Unidos em que é usual a utilização do termo iniciativa social (social venture), nos países em desenvolvimento o termo negócio social aparece com mais força.

Na América Latina, a principal referência acadêmica sobre negócios sociais é a rede Social Enterprise Knowledge Network (SEKN), formada por nove escolas de administração de empresas da América Latina, conforme apresentado no item 1 deste trabalho. 0 termo utilizado pela rede é "negócios inclusivos", definidos como organizações ou empreendimentos que geram transformação social por meio de atividades de mercado. Isso engloba ONGs, empresas ou empreendimentos que atuam em atividades do setor público e produzem produtos e serviços de valores significativos. Dessa forma, a caracterização de um negócio social está diretamente relacionada com sua intencionalidade e não ao formato jurídico (inexistente na América Latina). Muitos autores defendem não haver a necessidade de regulamentação jurídica para esta nova forma organizacional: "o determinante é a intenção explícita e consciente para criar valor para a comunidade, que vai além do benefício social gerado por uma empresa ao criar empregos." (GUTIÉRREZ; EZEQUIEL; TRUJILLO, 2006, p. 407, tradução nossa).

Segundo Márquez, Reficco e Berger (2009), não basta que um negócio social seja autossustentável e rentável, é essencial que o empreendimento gere benefícios socioambientais e transforme as condições de vida de uma determinada população.

A visão latino-americana reforça, ainda, o papel das pequenas e médias organizações, de forma que a população de baixa renda muitas vezes também participe da organização na função de produtores e não simplesmente consumidores. Dessa maneira, se diferencia da visão norte-americana que ressalta o papel das grandes corporações na oferta de bens e serviços para população de baixa renda.

No caso da vertente asiática, o grande inspirador e que disseminou internacionalmente o termo social business é Muhammad Yunus, prêmio Nobel da Paz, criador do Grameen Bank, primeira organização de microcrédito. Para Yunus (2007, p. 28), existem dois tipos de negócios sociais: (i) o primeiro abrange empresas focadas em prover um beneficio social, em 
vez de maximização do lucro do proprietário, tais como redução da pobreza, tratamento de saúde para pobres, justiça social, sustentabilidade global; (ii) o segundo tipo opera de uma maneira diferente, pois visa maximização de lucro, mas a propriedade é dos pobres ou marginalizados. Nesse caso, o benefício social deriva do fato de que os dividendos e o crescimento financeiro produzido irão beneficiar os pobres e reduzir sua pobreza.

Yunus (2007, p. 23-24) afirma que um negócio social é diferente de caridade ou de uma ONG. Assim como as tradicionais empresas maximizadoras de lucro, o negócio social tem proprietários, que são autorizados a recuperar seus investimentos. Esses podem ser um único indivíduo, uma parceria, um ou mais investidores que contratam gestores para operar o negócio ou, ainda, o governo ou filantropos ou qualquer combinação com diferentes tipos de negócios. Yunus (2007) ressalta que a maximização do valor social não é compatível com a maximização de lucro. Neste sentido, defende que o lucro seja totalmente reinvestido no empreendimento para que o negócio amplie suas atividades e gere maior impacto.

A partir das perspectivas abordadas, no próximo item serão listados os principais fatores que caracterizam este novo tipo de formato organizacional que concilia geração de valor socioambiental e geração de valor econômico. 


\section{4 - Características dos Negócios Sociais}

A partir das perspectivas analisadas, pode-se dizer que os negócios sociais possibilitam inserir a população do segmento de baixa renda e minorias no mercado formal e tem como preocupação a melhoria das condições de vida desta população e/ou a conservação da biodiversidade. Para alguns acadêmicos (PRAHALAD; HART, 2002), a melhoria das condições de vida é obtida quando se facilita o acesso dessas pessoas a quaisquer bens e serviços até então disponíveis somente para as camadas socioeconômicas mais privilegiadas. Os autores cunharam a expressão BoP (Base of the Pyramid) - "base da pirâmide" para identificar a população com menor poder aquisitivo. Nesse sentido, a proposição de Prahalad e Hart (2002) considera que todos os empreendimentos voltados para o atendimento das necessidades dos consumidores de baixa renda podem ser considerados negócios sociais, sem que necessariamente atuem em áreas que tenham impacto estrutural nas vidas das pessoas, tais como: saúde, educação ou moradia.

Autores como Karnani (2007) são mais críticos em relação a esta visão, considerando-a mercadológica e consumista porque ela não propiciaria reverter a situação de extrema pobreza e aumentaria os problemas ambientais decorrentes do excesso de consumo. Sen (2000) enfatiza que o principal problema da pobreza é a privação da liberdade humana e, para revertê-la, é necessário oferecer acesso e condições sociais e econômicas fundamentais, tais como: educação, serviços de saúde, energia, moradia e oportunidades de geração de renda. Nesta abordagem, seria mais adequado estimular iniciativas de mercado que ofereçam soluções para ampliar a oferta de produtos e serviços que atendam essas necessidades básicas e estruturais, as quais têm amplo impacto na melhoria das condições de vida das pessoas da "base da pirâmide".

Outra forma de analisar os negócios sociais está relacionada ao impulsionador do empreendimento. Prahalad e Hart (2002) reforçam o papel das multinacionais como atores fundamentais na proposição de soluções para o combate da pobreza no mundo. Entre suas habilidades estariam a capacidade de inovar, a agilidade na implementação das iniciativas e, sobretudo, o potencial de escala característico das grandes corporações. Khanna e Palepu (2006) contrapõem essa visão, reforçando a relevância das empresas locais que se tornam os "gigantes emergentes". Por conhecerem melhor as condições peculiares de seus países, têm 
enorme vantagem competitiva e são mais eficazes no atendimento e em oferecer acesso às pessoas da base da pirâmide. Por outro lado, vale ressaltar que estas empresas, apesar do bom conhecimento desse público e do ambiente de negócios onde se inserem, não têm, necessariamente, uma visão sobre as questões sociais locais. Em geral, atendem o segmento de baixa renda em função da proximidade e natureza do negócio em que atuam, e não, necessariamente, por terem uma intenção deliberada de construir um modelo de negócios com a intencionalidade de provocar impacto social positivo. Por outro lado, um estudo elaborado pela SEKN reforça o papel das pequenas e médias empresas, cooperativas e organizações da sociedade civil na oferta de soluções voltadas para a população de baixa renda. Nesta perspectiva, a população da base da pirâmide muitas vezes está na função de produtores e não simplesmente de consumidores.

O formato do empreendimento social também pode variar. É possível encontrar iniciativas de mercado voltadas para população de baixa renda e/ou minorias que são implementadas por organizações da sociedade civil que visam incrementar sua fonte de receita. Por outro lado, há iniciativas de mercado voltadas para atender os consumidores do segmento de baixa renda que são criadas dentro de empresas com fins lucrativos. Estas iniciativas podem fazer parte do core business ou representar uma atividade secundária ou periférica inserida na área de Responsabilidade Social Corporativa.

A divergência sobre a distribuição ou não de lucros está intimamente vinculada ao formato do negócio social. Há correntes que defendem que a distribuição de lucros faz parte da lógica de mercado e, portanto, não representaria um impeditivo ao crescimento do negócio e ao cumprimento de sua missão social. Ao contrário, abriria condições para atrair maiores investimentos externos, ampliando, assim, a escala e o efeito multiplicador da iniciativa (CHU, 2008; J.P.MORGAN, 2010). No entanto, a abordagem de especialistas como Yunus (2007) é totalmente contrária a esta posição, argumentando que os negócios sociais deveriam maximizar a riqueza social e não a individual. Dessa forma, defende-se o total reinvestimento do lucro no empreendimento a fim de beneficiar, exclusivamente, os atores sociais que são o objeto de atuação da iniciativa.

O modelo de governança dos negócios sociais não tem recebido muita atenção da literatura americana. No entanto, autores europeus como Galera e Borzaga (2009) ressaltam a importância de introduzir neste tipo de empreendimento formas mais coletivas e 
participativas de processo decisório. O envolvimento dos clientes/consumidores nesses processos seria essencial, principalmente, em organizações que assumem atividades desempenhadas pela administração pública, por exemplo, educação e saúde.

Negócios sociais geram valor econômico e valor socioambiental de forma intrínseca. A iniciativa deve cobrir todos os custos envolvidos. Márquez, Reficco e Berger (2010) explicam que, para as iniciativas desenvolvidas pelas organizações da sociedade civil, o valor econômico deveria ser definido como sustentabilidade financeira, ou seja, pela capacidade de operar indefinidamente. Para empresas privadas, o valor econômico é sinônimo de lucratividade. Segundo os autores, subsídios seriam aceitáveis nas seguintes situações: em startup ventures, como um recurso temporário para obter a sustentabilidade; ou quando os subsídios são oferecidos de forma horizontal, ou seja, para um setor ou indústria como um todo. Celli e González (2010) apontam as diferenças de comparar empresas que, desde o seu nascedouro, atuam, exclusivamente, para a população localizada na base da pirâmide socioeconômica, com empresas que foram incorporando essas pessoas às suas atividades tradicionais, como, por exemplo, projetos-pilotos executados por grandes corporações. Neste caso, é necessário calcular a taxa interna de retorno do projeto.

Em função da assimetria de informação e custos de transação, o mercado voltado para a base da pirâmide é mais custoso do que outros mercados (PRAHALAD; HART, 2002; CELLI; GONZÁLEZ, 2010). A partir da análise de 33 casos na região ibero-americana estudados pela SEKN, foi possível concluir que somente as iniciativas que introduziram inovações tecnológicas e novos arranjos institucionais conseguiram reduzir custos na cadeia de distribuição, obtiveram escala e ampliaram sua lucratividade.

Mensurar o impacto socioambiental não é algo trivial. Primeiro, deve-se definir o que é valor social e ambiental para depois mensurá-los. Na literatura sobre negócios sociais, há certa tendência de associar geração de valor social prioritariamente a geração de renda, traduzindo uma visão limitada do significado de pobreza. Sen (2000) observa que a pobreza é um fenômeno complexo e multidimensional, evidenciado pela desigualdade, informalidade e exclusão social. O autor enfatiza que para reverter uma situação de pobreza é necessário fortalecer as capacidades humanas, possibilitando a ampliação da liberdade de escolha dos indivíduos. No próximo item, são apresentadas categorias analíticas para classificar o valor socioambiental que pode ser gerado por empreendimentos sociais. 
Dessa forma, os principais itens que caracterizam este novo tipo de formato organizacional que concilia geração de valor socioambiental e geração de valor econômico são: finalidade, impulsionador do empreendimento, formato, distribuição ou não de lucros, modelo de governança, escala e impacto socioambiental. 


\subsection{1 - Geração de Valor Socioambiental}

O combate à pobreza, objetivo primário dos negócios sociais, exige um olhar amplo sobre as causas que levam a vulnerabilidade social da população de baixa renda e/ou das minorias. Torres e Barki (2013) mostram que é uma miopia associar pobreza a fatores exclusivamente econômicos. Os autores enfatizam que o combate à pobreza está vinculado ao aumento de ativos de uma determinada população: capital físico, que inclui terra e bens materiais; capital humano, que inclui educação, saúde e poder do trabalho; e capital social, relacionado à extensão e natureza das relações sociais.

O capital físico é comumente relacionado a estoque de bens materiais e ativos físicos de uma dada família. O direito à propriedade, especialmente em comunidades rurais, é um ponto-chave na discussão sobre pobreza. Em geral, este acesso formalizado legalmente pode ser considerado também como um importante obstáculo institucional para a redução da pobreza, pois permite a legitimação do capital, a utilização de seu potencial econômico e a integração do proprietário na sociedade (TORRES; BARKI, 2013). Sem acesso formal à propriedade, as famílias têm maior dificuldade de obter crédito, usando tais ativos como garantia.

Vários estudos identificaram como o investimento em capital humano tem um potencial de redução de pobreza e vulnerabilidade e de contribuir para o aumento do capital físico no médio prazo (WINTERS e CHIODI, 2011; DEARMON e GRIER, 2011 apud TORRES; BARKI; COMINI, 2015). Assim como o capital físico é criado por mudanças em ativos, o capital humano é criado a partir de mudanças nas pessoas que melhoram habilidades e capacidades (COLEMAN, 1988). O investimento em capital humano tem um grande potencial de redução da pobreza e aumento da riqueza: a cada ano adicional de estudo formal, a renda do trabalho aumentaria, em média, 16\% (NERI, 2001).

O capital social, por sua vez, é criado a partir das mudanças nas relações entre as pessoas que ampliam o seu universo de oportunidades. O capital social é menos tangível do que os outros tipos de capital. Um dos elementos relevantes para a criação de capital social é a existência de confiança em determinado grupo (COLEMAN, 1988). A essência do capital social está na rede de relacionamentos que incluem família, amigos e outras relações que 
provêm conhecimento e/ou apoio. Com o advento da telefonia móvel e a expansão das redes sociais por meio da internet - Facebook, Linkedin, Twitter etc. -, é cada vez mais evidente a importância dessa modalidade de ativo individual, influenciando a capacidade de ter acesso às oportunidades de diversas naturezas, inclusive de trabalho, negócios e emprego.

Além da perspectiva de aumento de ativos, Torres, Barki e Comini (2015) argumentam que os negócios sociais podem contribuir para a diminuição de custos de transação de pequenos produtores ou população carente. Custos de transação são geralmente entendidos como os custos incorridos por agentes econômicos que excedem os custos de produção propriamente ditos - capital, trabalho e matéria-prima - e passam a incluir outros aspectos aparentemente secundários ao processo produtivo, tais como custos associados a empréstimos (incluindo juros), marketing, seguros, taxa de risco, comunicações etc. Em finanças, os custos de transação estão, em geral, associados à negociação de ativos financeiros, tais como, taxas, juros, spreads e taxas de administração. A categoria "custos de transação" também tem sido utilizada amplamente na área de marketing, uma vez que essa disciplina lida diretamente com temas transacionais.

Menos comum, no entanto, tem sido pensar a categoria custos de transação na perspectiva das famílias ou de consumidores de baixa renda. Famílias mais pobres podem incorrer em custos importantes para transacionar. Por exemplo, o baixo grau de informação sobre preços pode levar a dispêndios desnecessários com determinados produtos. A localização da residência e as dificuldades de transporte podem implicar também custos importantes do ponto de vista dos consumidores mais distantes de centros comerciais e bancos. O famoso argumento relativo à penalização dos mais pobres (poverty penalty), em função de um acesso mais caro aos produtos de consumo, também pode ser pensado como uma modalidade específica de custo de transação incorrido por famílias (MENDOZA, 2011). De fato, as condições particulares de vida de determinados grupos de pobres, referidos especialmente ao local de moradia, podem induzir custos muito mais elevados em termos de acesso aos produtos e serviços privados, bem como em termos de proximidade ao mercado de trabalho e acesso aos serviços públicos (mesmo que gratuitos).

Outra forma de classificar a geração de valor social de negócios sociais é a separação entre aspectos tangíveis e intangíveis. A partir da análise de 33 negócios sociais na região ibero- 
americana, Portocarrero e Delgado (2010) enfatizam a importância de ampliar a visão de criação de valor das iniciativas voltadas para a população de baixa renda. Os autores defendem que a geração de valor deve contemplar a remoção das barreiras que impedem a inclusão social, que contemplam assistência à população mais marginalizada ou sem voz, bem como a mitigação dos efeitos negativos do crescimento econômico.

Nesse sentido, as iniciativas voltadas para a base da pirâmide deveriam ser avaliadas nos aspectos mais tangíveis (acesso a bens, serviços e geração de renda), e nos intangíveis (resgate de cidadania e desenvolvimento de capital social). Segundo os autores, haveria obstáculos legais, simbólicos e culturais envolvidos na exclusão social que impedem a satisfação de necessidades e o exercício dos direitos na promoção à cidadania. Um dos principais aspectos é a dificuldade da população de baixa renda para construir uma identidade como membros de uma sociedade maior e o senso de pertencimento que vai além das fronteiras da sua própria comunidade. No que se refere ao capital social, os autores comentam a necessidade de identificar de que forma as iniciativas sociais de mercado possibilitam a construção de uma rede calcada nos princípios da confiança, reciprocidade e cooperação mútua. 0

Quadro 1 sintetiza as categorias utilizadas pelos autores.

Como pode ser observado no

Quadro 1, não há nenhuma menção a fatores ambientais. Esta dimensão é incorporada na visão de fundos de investimento de impacto que enfatizam que a geração de impacto social e/ou ambiental positivo deve ser intencional, fazer parte da estratégia do negócio e, como tal, ser uma variável mensurada no sucesso do investimento (J.P.MORGAN, 2010).

Oliveira Filho, Kiyama e Comini (2013) fazem uma síntese dos principais indicadores para mensurar o impacto na perspectiva de investidores em negócios com impacto social. Em 2008, um grupo de investidores em negócios sociais organizou uma rede de troca de experiências e definição de padrões, a Global Impact Investment Network (GIIN). Em 2009, este grupo propôs o Impact Reporting and Investment Standards (IRIS) como uma forma padronizada de mensurar e relatar o impacto social e ambiental dos negócios sociais. Com o intuito de criar agências externas de rating para monitorar o impacto social deste tipo de investimento, em 2010, foi estruturado o GIIRS (Global Impact Investing Reporting 
Standards). Como pode ser observado por meio do Quadro 2, o IRIS ressalta objetivos sociais e ambientais bem tangíveis.

\section{Quadro 1 - Principais Elementos de Geração de Valor Social}

\section{Aumento de renda}

- Matérias-primas produzidas, principalmente em áreas rurais, para as empresas, particularmente produtos agrícolas ou relacionados à agricultura.

- Organização de produtores e associação ou incorporação a cadeias produtivas.

- Aumento de produtividade advindo de treinamento e assessoria técnica.

- Eliminação de intermediários.

- Certificação para produtos diferenciados.

- Melhores canais de marketing.

- Economia em compras frequentes.

Promoção de cidadania

- Reconhecimento e exercício de direitos básicos (vida, trabalho, etc.).

- Defesa de interesses públicos.

- Maior visibilidade e dignidade para setores de baixa renda e grupos excluídos.

- Intermediação de oportunidades de trabalho para pessoas com deficiência, grupos excluídos ou indivíduos não qualificados.

- Validação da identidade de indivíduos não registrados.

- Acesso físico ao mercado para vender a produção do setor de baixa renda.

- Consciência ambiental.

- Promoção de bons hábitos de higiene, ordem e consumo racional.

\section{Acesso a bens e serviços}

- Redução de preços.

- Pagamento fragmentado de bens e serviços e sistemas pré-pagos.

- Presença física em áreas rurais e áreas pobres urbanas.

- Investimentos privados em equipamentos, infraestrutura e redes de distribuição.

- Acesso flexível a mecanismos de empréstimos.

- Eliminação de barreiras á educação.

\section{Desenvolvimento de capital social}

- Construção de redes, relacionamentos locais e fortalecimento de capacidades.

- Construção de um sentimento de pertencimento a uma comunidade.

- Construção de rede social, confiança, reciprocidade e desenvolvimento de cooperação.

- Maior disponibilidade de recursos próprios e de terceiros por meio de contatos e interações.

- Capacitação do setor de baixa renda para agilizar e expressar as demandas.

- Melhora da autoestima

- Associação de interesses individuais.

- Ligar grupos sociais dispersos a administrações, empresas, novos mercados ou clientes locais.

Fonte: Portocarrero e Delgado (2010)

Quadro 2 - Indicadores Propostos - IRIS

\begin{tabular}{|c|c|c|}
\hline $\begin{array}{l}\text { Aumento de renda e de bens } \\
\text { para os pobres }\end{array}$ & $\begin{array}{l}\text { Melhoria do bem-estar básico para } \\
\text { pessoas carentes }\end{array}$ & Mitigar a mudança climática \\
\hline $\begin{array}{l}\text { Geração de emprego. } \\
\text { Acesso à energia. } \\
\text { Acesso aos serviços financeiros. } \\
\text { Acesso à educação. } \\
\text { Crescimento da } \\
\text { renda/produtividade. } \\
\text { Produtividade agrícola. } \\
\text { Capacitação. } \\
\text { Desenvolvimento comunitário. }\end{array}$ & $\begin{array}{l}\text { Resolução de conflitos. } \\
\text { Prevenção e mitigação de doenças. } \\
\text { Acesso à água limpa. } \\
\text { Habitação a preços acessíveis. } \\
\text { Segurança alimentar. } \\
\text { Geração de fundos para doações. } \\
\text { Melhoria da saúde. } \\
\text { Igualdade e empoderamento. }\end{array}$ & $\begin{array}{l}\text { Conservação da biodiversidade. } \\
\text { Eficiência em energia e } \\
\text { combustíveis. } \\
\text { Conservação de recursos naturais. } \\
\text { Prevenção da poluição e gestão de } \\
\text { resíduos. } \\
\text { Energia sustentável. } \\
\text { Uso sustentável da terra. } \\
\text { Gestão de recursos hídricos. }\end{array}$ \\
\hline
\end{tabular}


Embora tenha sido inovador ao incorporar os fatores ambientais, a taxonomia do IRIS não diferencia elementos contributivos ao aumento do capital natural, ou seja, a diferença entre a oferta de serviços ecossistêmicos e os elementos que apenas mitigam impactos negativos de uma economia de alta emissão de carbono. Os serviços ecossistêmicos podem ser obtidos por meio de quatro tipos de serviços (MEA, 2005)

(i) Provisão: produtos obtidos do ecossistema (alimento, água, combustível, fibra, madeira, recursos genéticos);

(ii) Regulação: benefícios obtidos pela regulação do clima, de enfermidades, controle biológico, regulação da água, purificação da agua, proteção contra tempestades e polinização;

(iii) Culturais: benefícios intangíveis (espirituais, religiosos, recreativos, herança cultural, educacional);

(iv) Suporte (necessários para a produção de outros serviços ecossistêmicos como formação de solo, nutrientes, produção primária).

O grande desafio para um desenvolvimento sustentável do ponto de vista ambiental é manter os serviços ecossistêmicos ao longo do tempo em face de mudanças ambientais e, para isso, a conservação da biodiversidade tem um papel fundamental. Pesquisas realizadas por cientistas e economistas (TEEB, 2009) mostram que é muito mais barato e eficiente investir na conservação da biodiversidade do que restaurar ecossistemas danificados. Uma ação importante seria o investimento na gestão de áreas protegidas de forma a obter maior quantidade de serviços ecossistêmicos.

Dados do relatório TEEB - The Economics of Ecosystems and Biodiversity for national and international Policy Makers (TEEB, 2009) mostram que um bilhão de pessoas - um sexto da população mundial - dependem de áreas protegidas para garantir uma percentagem significativa dos seus meios de subsistência, tais como: alimento, combustível ou apoio à atividade econômica. Ao mesmo tempo, a oferta de serviços ecossistêmicos ultrapassa os limites das áreas protegidas. Portanto, é necessário manejar adequadamente os ecossistemas em paisagens agrícolas e em ambientes urbanos, no sentido de evitar a deterioração do capital natural. 
Evitar a perda do ecossistema é a melhor opção. No entanto, onde já é tarde demais, a restauração do capital natural pode proporcionar também um bom retorno. Estimativas preliminares apresentados no TEEB (2009) mostram que, se levar em conta os vários serviços ecossistêmicos, os retornos sociais potenciais da restauração podem chegar a $40 \%$ para mangue e cerrados, 50\% para as florestas tropicais e 79\% para pastagens. Além disso, o relatório TEEB (2009) destaca quatro estratégias que deveriam ser desenvolvidas em todos os países: 1) deter o desmatamento e degradação florestal de forma a mitigar os efeitos de mudanças climáticas e preservar maior variedade de bens e serviços das florestas para comunidades locais; 2 ) proteger recifes e coral tropicais para evitar aumento da temperatura global e acidificação dos oceanos; 3) salvar e restaurar pesca mundial e 4) reconhecer a interligação entre degradação do ecossistema e a persistência de pobreza rural.

Biodiversidade e serviços ecossistêmicos são ativos naturais com um papel chave para um desenvolvimento sustentável. A biodiversidade é importante para todos, mas essencial para a população rural pobre, que dependem diretamente para a sua alimentação, moradia, renda e qualidade de vida. Nesse sentido, é fundamental pensar em alternativas econômicas geradoras de renda que ajudem reverter a situação de pobreza para esta população e, ao mesmo tempo, impactem positivamente a oferta de serviços ecossistêmicos. Alguns exemplos são as atividades de turismo sustentável que beneficiam uma unidade de conservação. Ou, ainda, atividades comunitárias voltadas para o plantio florestal e utilização de sistemas agroflorestais (SAF), que minimizam riscos de degradação do solo inerentes à atividade agrícola e otimizam sua produtividade.

Pádua (2015), fundador do Instituto de Pesquisas Ecológicas, identifica seis áreas de atuação prioritárias para empreendimentos socioambientais que visam contribuir para uma economia de baixo carbono e com uso eficiente de recursos: ecoturismo, neutralização de carbono, bancos de habitat para espécies, restauração florestal, compensação de reservas legais e biotecnologia. É necessário estruturar empreendimentos econômicos para inovar processos produtivos de forma a não agredir o meio ambiente, como, por exemplo, substituir processos químicos tradicionais por composições enzimáticas no setor de tratamento de efluente, beneficiamento têxtil etc.

Investimento bem orientado em capital natural pode fornecer taxas de retorno satisfatórias e proporcionar mais benefícios do que simplesmente desenvolver ações mitigatórias de 
combate ao efeito estufa. Variedade e abundância de espécies permitem descobertas medicinais e estimulam a aplicação em diferentes segmentos como, por exemplo, cosméticos e gastronomia.

Levando em conta as referências teóricas apresentadas neste item, que investigaram os fatores que ajudam a combater a pobreza e conservar a biodiversidade, este trabalho propõe nove categorias para analisar a contribuição dos negócios sociais na geração de valor socioambiental: aumento de capital físico, capital produtivo, capital humano, capital social, cidadania, diminuição de custos de transação, capital natural, contribuição para uma economia de baixo carbono e reuso de materiais. A Figura 1, a seguir, apresenta alguns exemplos em cada categoria.

Figura 1 - Geração de Valor Socioambiental

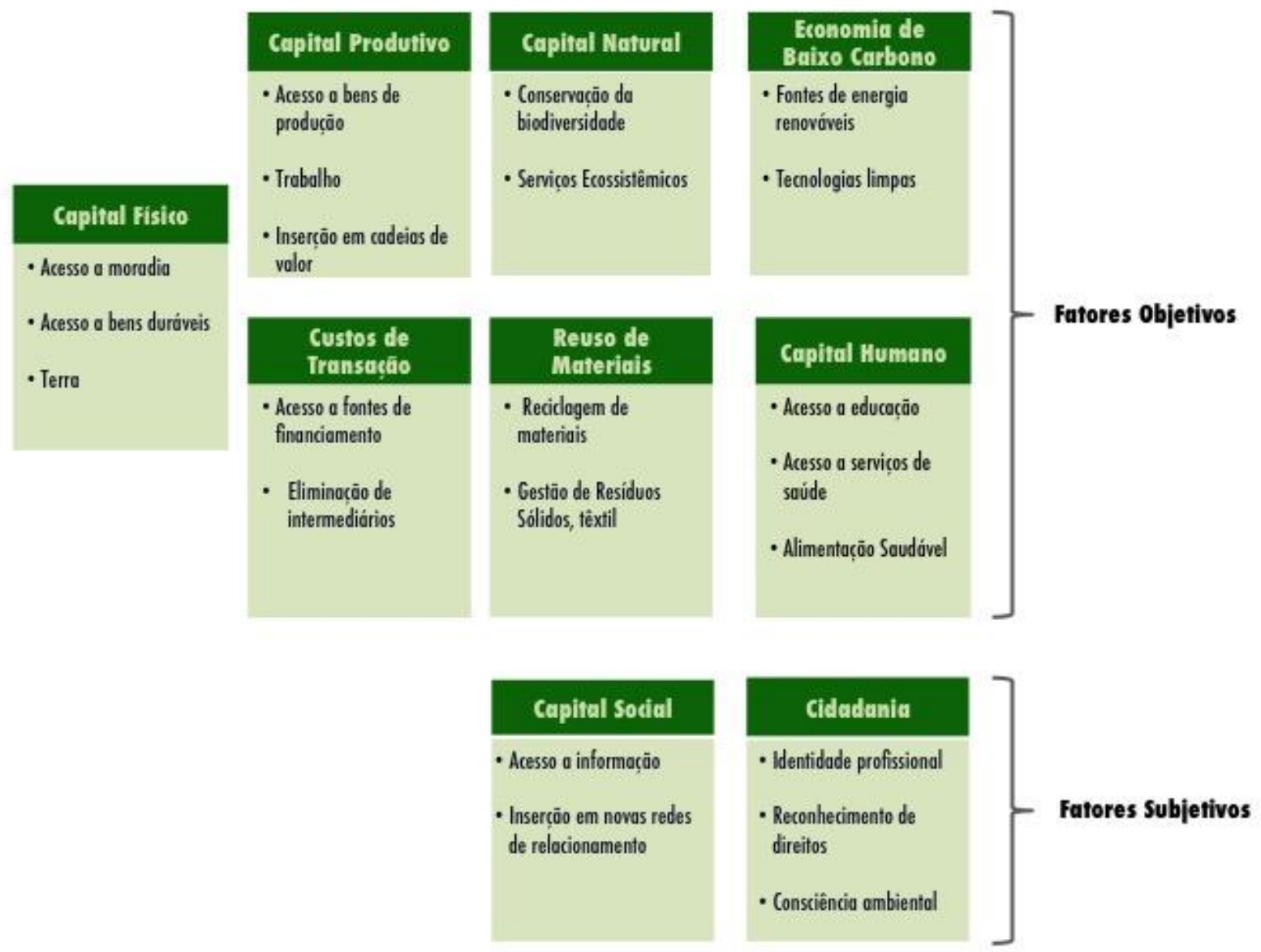




\section{5 - Quadro Analítico para Compreensão dos Negócios Sociais}

Ao analisar as diferentes definições e características de negócios sociais apresentadas nos itens 2.3 e 2.4, respectivamente, é possível elencar quatro categorias que demarcam as diferenças entre as abordagens/correntes encontradas na literatura sobre negócios sociais, a saber: finalidade do empreendimento, cadeia de valor, estrutura de governança e sustentabilidade financeira.

Da mesma forma que Austin (2002) propôs um continuum para descrever a tipologia das alianças e parcerias intersetoriais, pode-se também construir um continuum para descrever os tipos de negócios sociais. Na concepção de Battilana, Lee, Walker e Dorsey (2012), os negócios sociais são organizações híbridas, pois possuem dois tipos de objetivos: geração de valor socioambiental e valor econômico. Embora todos os negócios tenham estes mesmos objetivos, os quais representam um denominador comum, eles se diferenciam na ação. Nesse sentido, pode-se dizer que há diferentes graus de hibridismo (ALTER, 2007), como mostra a Figura 2.

De um lado extremo, há negócios sociais que atuam com forte ênfase no mercado, muito similar a uma empresa tradicional ("business as usual"); no outro extremo, há empreendimentos sociais que, mesmo operando como negócios que visam rentabilidade financeira, tem um modus operandi muito similar ao de uma organização da sociedade civil. Entre estes dois extremos, encontram-se boa parte dos negócios sociais os quais se estruturam de forma similar a uma empresa em determinados fatores e se aproximam de uma ONG em outros itens (vide

Quadro 3).

Figura 2 - Continuum da Tipologia de Negócios Sociais

Lógica de Mercado

Lógica Social

Fonte: elaborada pela autora

Este trabalho não tem a finalidade de propor uma única definição de negócio social que deva ser considerada como a mais correta e adequada. Muito pelo contrário, valoriza-se a diversidade de formatos. Os empreendimentos sociais devem ser analisados de acordo com 
suas especificidades, história, valores e cultura, as quais delimitam suas características organizacionais e administrativas.

Quadro 3 - Continuum da Tipologia de Negócios Sociais

\begin{tabular}{|c|c|c|c|}
\hline \multirow{5}{*}{ 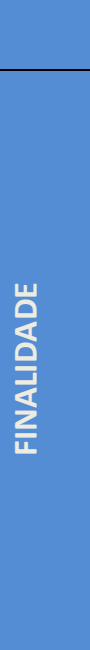 } & Fatores & Lógica de Mercado & Lógica Social \\
\hline & Objetivo principal & $\begin{array}{l}\text { Aproveitar uma oportunidade de } \\
\text { mercado }\end{array}$ & Resolver um problema socioambiental \\
\hline & Oferta & $\begin{array}{l}\text { Bens e serviços voltados para o } \\
\text { consumo da população }\end{array}$ & $\begin{array}{l}\text { Bens e serviços voltados para necessidades } \\
\text { básicas da população ou que conservem a } \\
\text { biodiversidade }\end{array}$ \\
\hline & Intencionalidade & $\begin{array}{l}\text { Geração de valor social é um } \\
\text { componente importante, porém } \\
\text { não central. }\end{array}$ & $\begin{array}{l}\text { Geração de valor socioambiental é o core } \\
\text { business do negócio }\end{array}$ \\
\hline & Escala & Fator relevante & $\begin{array}{l}\text { Replicabilidade é mais relevante que a } \\
\text { escalabilidade }\end{array}$ \\
\hline \multirow{3}{*}{ 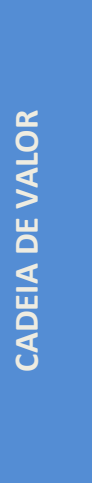 } & Clientes & $\begin{array}{l}\text { Os clientes pertencem a diversas } \\
\text { classes sociais }\end{array}$ & $\begin{array}{l}\text { Predominantemente segmentos da } \\
\text { população que estão em situação de maior } \\
\text { vulnerabilidade social }\end{array}$ \\
\hline & Fornecedores & $\begin{array}{l}\text { Os critérios para escolha são } \\
\text { preço e qualidade }\end{array}$ & $\begin{array}{l}\text { Procura-se contratar segmentos da } \\
\text { população que estão em situação de maior } \\
\text { vulnerabilidade social }\end{array}$ \\
\hline & Colaboradores & $\begin{array}{l}\text { Não há nenhuma prioridade na } \\
\text { contratação }\end{array}$ & $\begin{array}{l}\text { Prioridade para segmentos da população } \\
\text { que estão em situação de maior } \\
\text { vulnerabilidade social }\end{array}$ \\
\hline 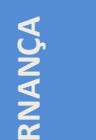 & $\begin{array}{l}\text { Processo } \\
\text { decisório }\end{array}$ & $\begin{array}{l}\text { Não há mecanismos institucionais } \\
\text { para participação coletiva }\end{array}$ & $\begin{array}{l}\text { Há mecanismos institucionais para } \\
\text { participação coletiva das comunidades com } \\
\text { as quais o empreendimento atua. }\end{array}$ \\
\hline \multirow{2}{*}{ 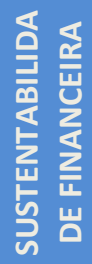 } & $\begin{array}{l}\text { Distribuição de } \\
\text { lucro }\end{array}$ & Distribuição de dividendos. & $\begin{array}{l}\text { Lucro é totalmente investido no } \\
\text { empreendimento }\end{array}$ \\
\hline & Valor econômico & $\begin{array}{l}\text { Todos os recursos são } \\
\text { provenientes de vendas de } \\
\text { produtos e serviços }\end{array}$ & $\begin{array}{l}\text { Depende de doações e/ou contribuições } \\
\text { institucionais para desenvolver sua } \\
\text { atividade principal }\end{array}$ \\
\hline
\end{tabular}

Fonte: Elaborado pela autora.

A forma como os negócios com impacto social estruturam e ofertam seus produtos e serviços a fim de gerar valor socioambiental nos remete ao debate de inovação social. Tal como o conceito de negócios sociais, inovação social também é considerado um conceito polissêmico (BIGNETTI, 2011; DEFOURNY; NYSSENS, 2012) e intimamente ligado a soluções 
novas para necessidades sociais. A pergunta que fica é: até que ponto negócios sociais são geradores de inovação social? 


\section{6 - INOVAÇÃO SOCIAL COMO UM CAMPO DE ESTUDO}

Diversos estudos internacionais mapearam a evolução das pesquisas em inovação social ao longo do século XX e apontaram o caráter multidisciplinar deste campo de estudo que possui abordagens na sociologia, economia, geografia, ciência política, engenharia ambiental, administração, entre outras (CROSSAN; APAYDIN, 2010; SHARRA; NYSSENS, 2010; MOULAERT et al., 2013). De Bruin e Stangl (2013, p. 1) enfatizam que " while the term social innovation is relatively new, its practice is not. The practice of individuals, partnerships and community grupos working together in innovative ways to devise and implement resourceful solutions to complex social problems, has a long history".

Este fato atesta a demora da produção acadêmica para reconhecer a inovação social como um campo de estudo. Em levantamento bibliométrico realizado por Silveira e Turri (2015) no período de 1991 a 2015, observa-se que o termo inovação social aparece em periódicos no início da década de 1990 de forma muito pontual, apresentando um crescimento exponencial a partir do ano de 2010.

As autoras identificam três clusters de co-citações: o primeiro grupo tem como foco principal a discussão do conceito de inovação social, o segundo grupo de artigos relacionam inovação social e empreendedorismo social e o terceiro grupo tem uma abordagem macroeconômica e sociológica sobre este fenômeno social.

Moulaert et al. (2013) explicam que o contínuo interesse na comunidade científica pela temática a partir dos anos 2000 está associado a três motivos principais:

(i) Crescimento dos problemas socioambientais decorrente das formas de produção econômica inerentes ao sistema capitalista e da incapacidade do governo de atender as demandas sociais;

(ii) Falta de metodologias que sejam consenso entre pesquisadores e comunidade prática e que envolvam interesses de diferentes stakeholders;

(iii) Desejo de contribuir teoricamente e de forma prática na transformação da sociedade moderna.

Nesse sentido, a literatura sobre inovação social não aborda apenas soluções para o atendimento de necessidades sociais e ambientais não contempladas pela ação pública ou 
atuação privada tradicional com fins lucrativos. A produção trata também sobre como as relações sociais podem ser reconfiguradas com maior empoderamento e mobilização política de população marginalizada no desenho das soluções. Sharra \& Nyssens (2010) mostram que há na literatura duas lentes preponderantes para compreender este fenômeno social: uma de resultado e outra de processo.

No primeiro caso, a visão é mais normativa. Conceitua inovação social como uma solução para um problema social que seja mais efetiva, eficiente e sustentável do que as alternativas existentes (PHILLS; DEIGLMEIER; MILLER, 2008). Nesta corrente, há três critérios para analisar uma inovação social: originalidade (a solução deve ser nova para usuário, contexto ou mercado), tipo de demanda social não atendida e a intencionalidade do executor que deve ser primordialmente social.

A segunda lente de debate de inovação social prioriza a análise do processo, ou seja, como a inovação emerge, de que forma é adotada e como é difundida. Mulgan (2006, p.21), divide o processo em quatro estágios: o ponto de partida de inovação é a conscientização de uma necessidade não atendida e de que exige participação e envolvimento da comunidade. 0 segundo estágio, caracterizado pela fase de teste e prototipagem, também exigirá envolvimento dos beneficiários para que seja possível identificar aprimoramentos. A terceira etapa refere-se à fase de escala ou replicabilidade da alternativa. A última e quarta etapa envolve a sistematização do aprendizado obtido.

Estas duas lentes explicam as razões pelos quais os conceitos de inovação social são tão diferentes. Como dizem Pol e Ville (2009, p. 881), "social innovation is a term that almost everyone likes, but nobody is quite sure of what it means"(Pol \& Ville, 2009, p.881).

Bignetti (2011) faz uma síntese das definições encontradas na literatura. Como pode ser observado no

Quadro 4, as discussões encontradas na literatura sobre inovação social focam na distinção entre resultado e processo. Além disso, os estudos encontrados até o presente momento não fazem uma ponte entre inovação tradicional e inovação social. Tratam este último como um campo de estudo totalmente diferente. 
Quadro 4 - Definições de Inovação Social

\begin{tabular}{|c|c|c|}
\hline Autor & Conceito & Lente \\
\hline Taylor (1970) & $\begin{array}{l}\text { Formas aperfeiçoadas de ação, novas formas de fazer as coisas, novas } \\
\text { invenções sociais. }\end{array}$ & Resultado \\
\hline $\begin{array}{l}\text { Dagnino e } \\
\text { Gomes (2000) }\end{array}$ & $\begin{array}{l}\text { Conhecimento - intangível ou incorporado a pessoas ou equipamentos, } \\
\text { tácito ou codificado - que tem por objetivo o aumento da efetividade dos } \\
\text { processos, serviços e produtos relacionados à satisfação das necessidades } \\
\text { sociais. }\end{array}$ & Resultado \\
\hline Cloutier (2003) & $\begin{array}{l}\text { Uma resposta nova, definida na ação com efeito duradouro, para uma } \\
\text { situação social considerada insatisfatória, que busca o bem-estar dos } \\
\text { indivíduos e/ou comunidade. }\end{array}$ & Resultado \\
\hline $\begin{array}{l}\text { Standford } \\
\text { Social } \\
\text { Innovation } \\
\text { Review (2003) }\end{array}$ & $\begin{array}{l}\text { Refere-se ao processo de inventar, garantir apoio e implantar novas } \\
\text { soluções para problemas e necessidades sociais. }\end{array}$ & Processo \\
\hline $\begin{array}{l}\text { Novy e Leubolt } \\
(2005)\end{array}$ & $\begin{array}{l}\text { A inovação social deriva principalmente de: satisfação de necessidades } \\
\text { humanas básicas, aumento na participação política de grupos } \\
\text { marginalizados, aumento na capacidade sociopolítica e no acesso aos } \\
\text { recursos necessários para reforçar direitos que conduzam à satisfação das } \\
\text { necessidades humanas e à participação. }\end{array}$ & Resultado \\
\hline $\begin{array}{l}\text { Moulaert et al } \\
(2007)\end{array}$ & $\begin{array}{l}\text { Ferramenta para uma visão alternativa de desenvolvimento urbano, } \\
\text { focada na satisfação das necessidades humanas (e empowerment) por } \\
\text { meio da inovação nas relações sociais e da governança comunitária. }\end{array}$ & Processo \\
\hline $\begin{array}{l}\text { Mulgan et al } \\
(2007)\end{array}$ & $\begin{array}{l}\text { Novas ideias que funcionam na satisfação de objetivos sociais, atividades } \\
\text { inovativas e serviços que são motivados pelo objetivo de satisfazer } \\
\text { necessidades sociais. São predominantemente desenvolvidas e difundidas } \\
\text { por organizações cujos propósitos primários são sociais. }\end{array}$ & Processo \\
\hline $\begin{array}{l}\text { Phills et al } \\
(2008)\end{array}$ & $\begin{array}{l}\text { O propósito de buscar uma nova solução mais efetiva, eficiente, } \\
\text { sustentável ou justa para um problema social do que as soluções } \\
\text { existentes e para o qual o valor criado atinge principalmente a sociedade } \\
\text { como todo e não indivíduos em particular. }\end{array}$ & Resultado \\
\hline $\begin{array}{l}\text { Pol e Ville } \\
(2009)\end{array}$ & $\begin{array}{l}\text { Nova ideia que tem potencial de melhorar a qualidade ou quantidade de } \\
\text { vida }\end{array}$ & Resultado \\
\hline $\begin{array}{l}\text { Murray et al } \\
(2010)\end{array}$ & $\begin{array}{l}\text { Novas ideias (produtos, serviços e modelos) que simultaneamente } \\
\text { satisfazem necessidades sociais e criam novas relações ou colaborações } \\
\text { sociais. Em outras palavras, são inovações que, ao mesmo tempo, são } \\
\text { boas para a sociedade e aumentam a capacidade de agir. }\end{array}$ & Processo \\
\hline Bignetti (2011) & $\begin{array}{l}\text { Inovação social é definida como resultado do conhecimento aplicado a } \\
\text { necessidades sociais por meio da participação e da cooperação de todos } \\
\text { os atores envolvidos, gerando soluções novas e duradouras para grupos } \\
\text { sociais, comunidades ou para a sociedade em geral. }\end{array}$ & Processo \\
\hline
\end{tabular}


Bignetti (2011) apresenta cinco dimensões que demarcam as diferenças. Em primeiro lugar, há uma diferença na questão do valor: a inovação tecnológica enfatiza a apropriação de valor (autointeresse dos atores econômicos que poderão usufruir de lucros altos pela exploração de uma oportunidade) e inovação social enfatiza a criação de valor (atendimento de necessidade não atendida de forma satisfatória pela comunidade). A segunda diferença está relacionada à estratégia, pois, enquanto na literatura tradicional de inovação buscamse vantagens competitivas, a literatura sobre inovação social enfatiza a necessidade de alianças e colaboração para viabilizar transformação social duradoura.

A terceira dimensão diferenciadora se refere ao locus da inovação. Segundo Bignetti (2011) o locus da inovação tradicional é centrado na empresa com altos recursos em pesquisa e desenvolvimento. Já no caso da inovação social, as ações são estruturadas na comunidade com esforços pequenos e locais. A quarta diferença se relaciona ao processo: a inovação tecnológica tem sido abordada em etapas sequenciais controladas por ferramentas de gestão, por outro lado, a inovação social, para ser bem sucedida, deve ser fruto de uma construção coletiva. Isto significa que as fases de concepção, desenvolvimento e implementação estão intimamente interligadas e são realizadas por meio da cooperação entre os atores envolvidos, em um processo continuo de idas e vindas.

No entanto, é importante destacar que a literatura de inovação desenvolvida por empresas com fins lucrativos tem avançado no que se refere ao processo de desenvolvimento. Autores como Chesbrough (2006) enfatizam benefícios da cooperação com outros parceiros, dentro dos conceitos de inovação aberta: "If firms cannot or don't wish to develop sufficient absorptive capacity themselves, they may utilize alliances in order to gain such knowledge or utilize complementary resources to exploit that knowledge"(CHESBROUGH, 2006, p. 9).

A quinta dimensão configura-se como a mais importante diferença, visto que aborda a difusão do conhecimento. Segundo Bignetti (2011, p. 7) "mecanismos de proteção intelectual procuram impedir que uma ideia ou uma tecnologia desenvolvida possa ser copiada e utilizada por concorrentes [...] as inovações sociais, no entanto, seguem 
mecanismos de difusão que favorecem a replicação e a expansão dos resultados para outras comunidades".

A opção deste trabalho é considerar a inovação social na perspectiva de resultado, ou seja, na geração de valor socioambiental para uma comunidade a partir da introdução de novos produtos/serviços ou processos em um determinado mercado ou contexto. Essa definição foi defendida no primeiro Fórum de Inovação Social realizado na OECD em 2000, pelo Programa Local Economic and Employment Development (LEED), Isto quer dizer que, neste trabalho, os fins demarcarão a diferença básica entre uma inovação tradicional e uma inovação social e não o locus/ator que a concebe e implementa (PHILLS; DEIGLMEIER; MILLER, 2008; MURRAY; CAULIER-GRICE; MULGAN, 2010). Este aspecto é importante porque os estudos de inovação social, com uma abordagem de empreendedorismo social (DEES, 2001), associam a inovação apenas às organizações sem fins lucrativos. Como mostra De Bruin e Stangl (2013) os estudos acadêmicos evoluíram o suficiente para aceitar que o locus da inovação social não é apenas na sociedade civil: "Scholarly study has progressed sufficiently to accept that the locus of social innovation is not only civil society. Social innovation can occur in the non-profit sector, the private or public sectors and intersect across sectors" (DE BRUIN, STANGL, 2013, p.1).

Este trabalho tem como objetivo contribuir com a literatura brasileira sobre inovação social ao analisar se e como negócios sociais estão implementando inovações que visam a transformação socioambiental. 


\subsection{1 - Recorte Analítico para o Estudo de Inovação Social}

A literatura de inovação social não faz uma clara distinção entre os determinantes da inovação e as dimensões da inovação, como apresentam Crossan e Apaydin (2010). A partir de uma revisão sistemática dos artigos sobre inovação de 1981 a 2008, os autores propõem um framework que distingue os determinantes da inovação (liderança, competências organizacionais e gestão) das dimensões analíticas da inovação (processo e resultado). $\mathrm{Na}$ perspectiva de processo, a pergunta básica é como ocorre a inovação? (How?) e na perspectiva de resultado, a questão passa a ser o que está sendo feito e para qual finalidade (What e What Kind?), vide Figura 3.

Figura 3 - Framework para Análise de Inovação Organizacional

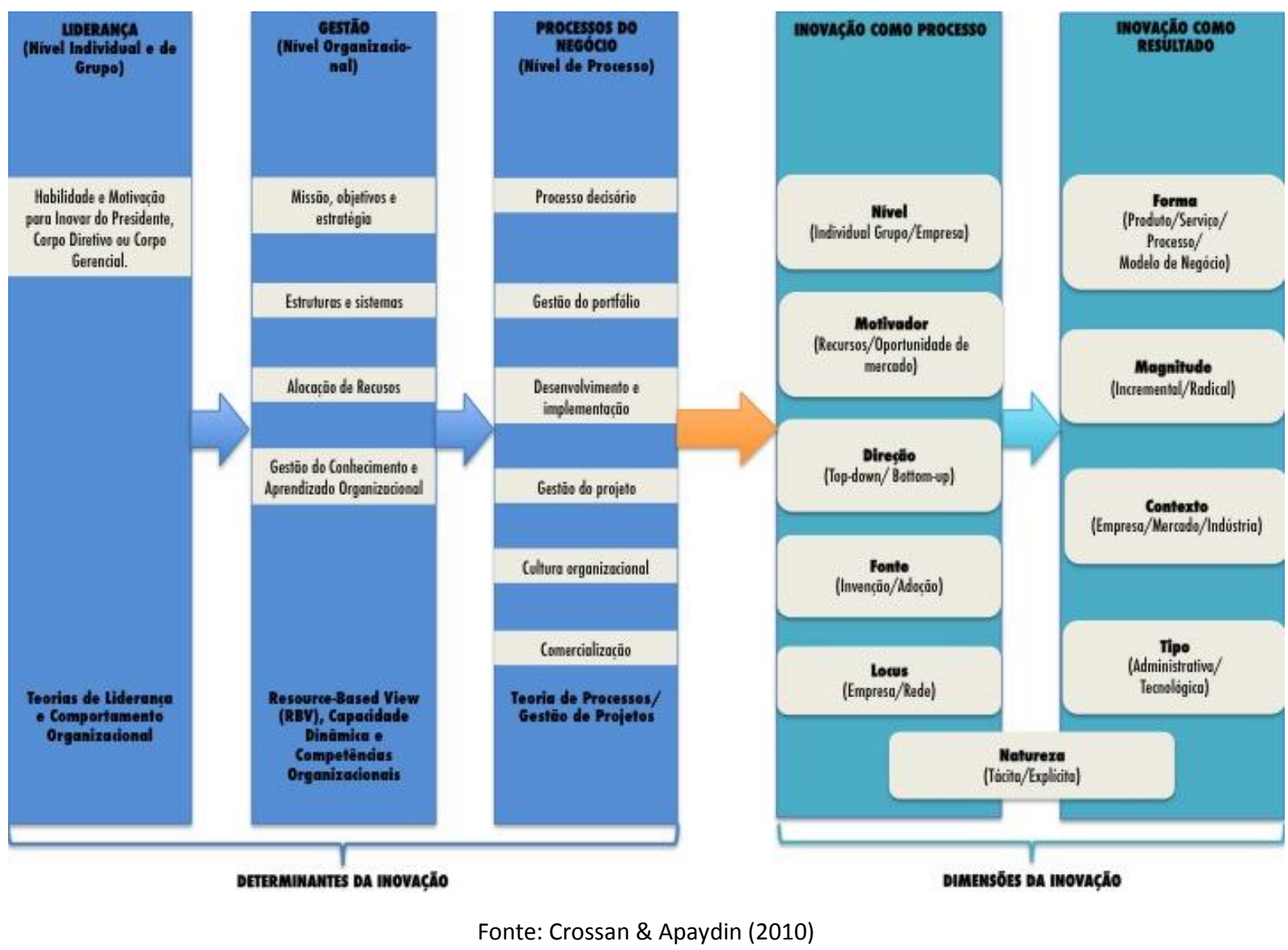

De Bruin e Stangl (2013) propõem dimensões específicas para análise de inovação social como outcome (resultado). Os autores destacam três aspectos a serem considerados: tipo de inovação, magnitude e extensão da escala/impacto. $O$ tipo de solução remete à descrição prevista no Manual de Oslo (OECD, 2005) que define inovação como sendo a implementação 
de um produto (bem ou serviço) novo ou significativamente melhorado, ou mudanças significativas nos métodos de produção e de logística (inovação de processo), ou uma nova forma de atender o cliente (inovação mercadológica / marketing), ou novas práticas organizacionais (inovação organizacional). A magnitude implica analisar se a solução proposta está direcionada para suprir uma falha de mercado e, neste caso, representaria apenas uma inovação incremental, ou para reconfigurar a estrutura de mercado, tornandose uma inovação institucional. Ela pode, ainda, para alterar o sistema social tornando-se uma inovação disruptiva. A extensão da escala/ impacto pode ser classificada em local; nacional ou global (Vide Figura 4).

Figura 4 - Continuum de Inovação Social

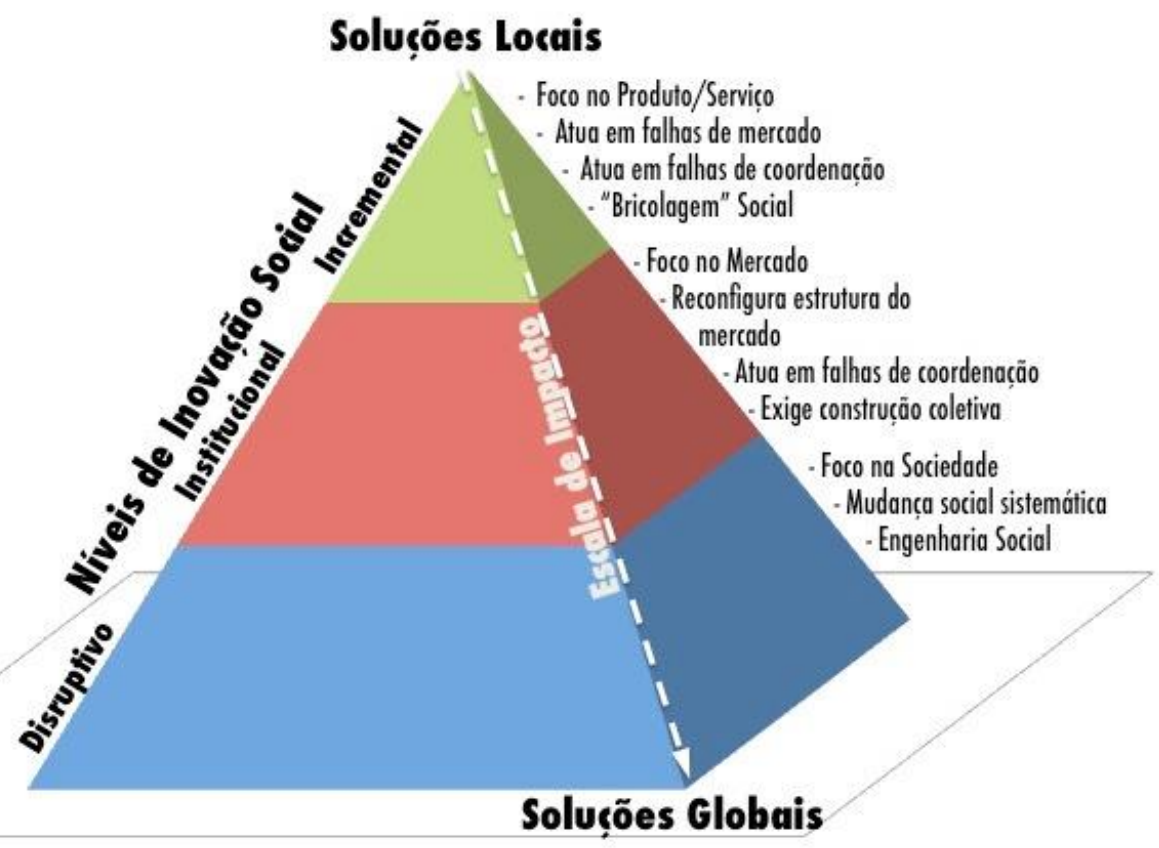

Fonte: De Bruin e Stangl (2013)

Christensen et al. (2006) enfatizam que, em qualquer setor, as empresas atuantes utilizam seus recursos e desenham seus modelos de negócio de forma a manter sua competitividade. Nesse sentido, é mais difícil surgirem inovações que desafiam o status quo e que ofereçam soluções disruptivas. Normalmente, são soluções mais simples, mais baratas e com qualidade que tornam o produto/serviço mais acessível. Ao aplicar o conceito de inovação disruptiva no contexto social, os autores cunham o termo inovação catalítica ${ }^{7}$, que teria como características: a) criar uma mudança social sistemática por meio de sua escala ou

\footnotetext{
${ }^{7}$ Catlytic innovations are a subset of dsruptive innovations, disntiguished by their primary focus on social change, often on a national scale. (Christensen et al, 2006, p. 96)
} 
replicabilidade; b) atender uma necessidade ainda não atendida, ou que está sendo atendida por meio de uma solução mais complexa; c) oferecer produtos e serviços que são mais simples e mais baratos do que as alternativas existentes; d) ser concebida por meio de doações de recursos ou capital intelectual não remunerado porque não é vista como interessante pelos competidores atuais e, por fim, são geralmente ignoradas ou desencorajadas pelos atores atuantes porque se imagina que o modelo de negócios não será rentável.

Como já apontado anteriormente, este trabalho tem como objetivo analisar a inovação socioambiental como resultado. Para isso, utilizará a abordagem De Bruin e Stangl (2013) apresentada anteriormente na figura 4, ou seja, tipo de solução, magnitude e extensão da escala. Dado que os empreendimentos sociais, foco deste estudo, se diferenciam pelos seus objetivos socioambientais, considera-se fundamental adicionar uma quarta dimensão de análise a fim de materializar a intencionalidade, ou seja, sua finalidade (geração de valor socioambiental). A Figura 5 apresenta a lente de análise utilizada neste trabalho, composta por quatro categorias: tipo de solução, abrangência (equivalente à magnitude), profundidade (em referência à escala) e finalidade.

Figura 5 - Dimensões de Análise de Inovação Social

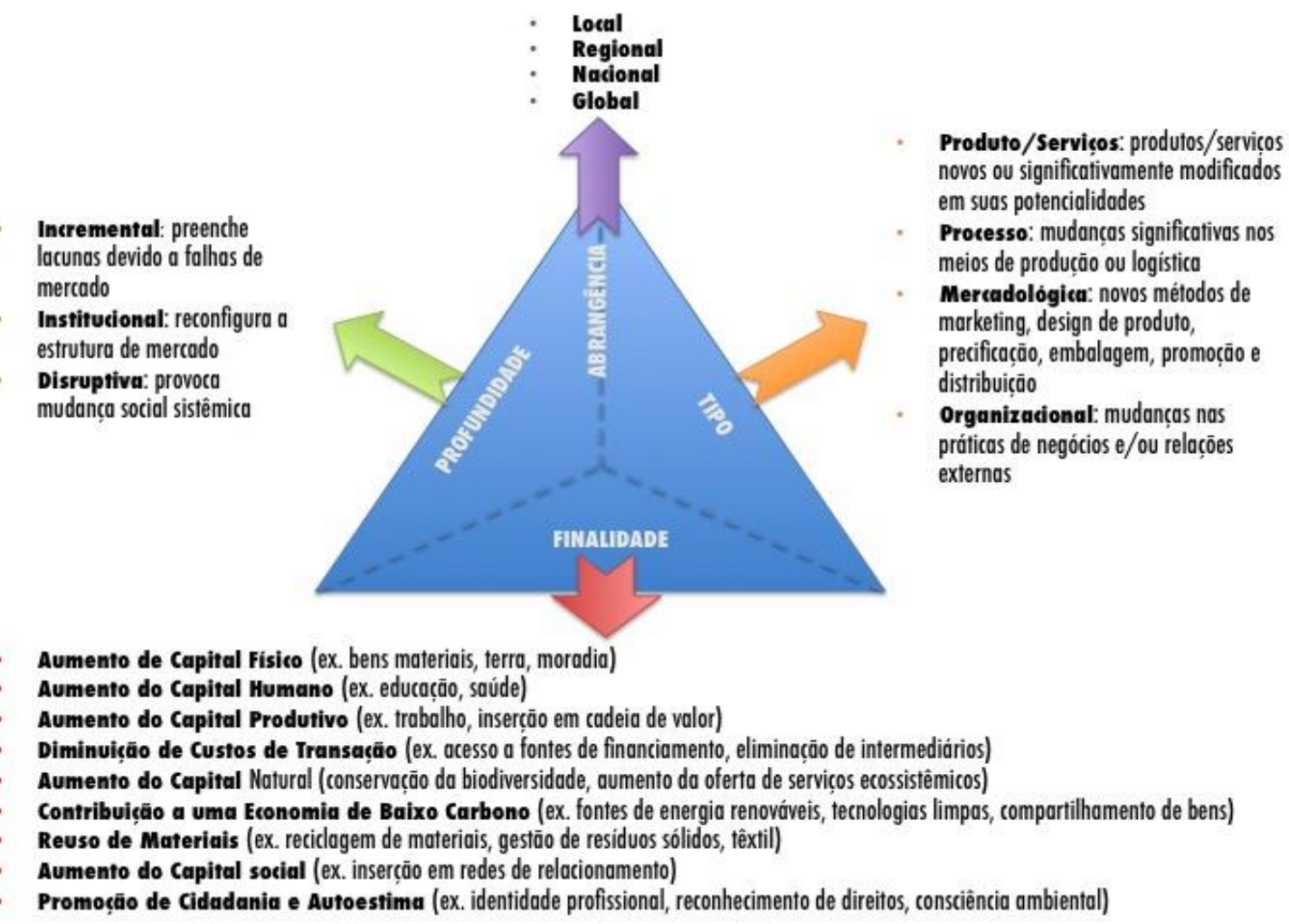

Fonte: elaborado pela autora 


\section{3 - METODOLOGIA}

\section{1 - Procedimentos de Pesquisa}

Este estudo tem como objetivo analisar a relação entre a Inovação Social e Negócios Sociais. Dá continuidade aos resultados de uma pesquisa exploratória, denominada Brasil27, cujos objetivos foram identificar e descrever empreendimentos existentes nos 27 estados brasileiros que pudessem ser caracterizados como negócios sociais ${ }^{8}$.

Os procedimentos metodológicos adotados em uma pesquisa científica são totalmente influenciados pela perspectiva e paradigma adotado pelo pesquisador em relação à construção do conhecimento (SELLTIZ et al., 1974; GEPHART, 1999; RYNES; GEPHART, 2004) e implicam em diferentes habilidades, pressupostos e práticas de pesquisa (POZZEBON; PETRINI, 2013). A autora do presente estudo tem como pressuposto que o conhecimento científico é resultante de um processo de construção coletiva e, portanto, a compreensão de uma realidade específica envolve identificar significados próprios para um dado contexto. Dessa forma, "não se deve confundir objetividade com certeza, pois todo conhecimento é sempre uma tentativa" (ALVES-MAZZOTTI; GEWANDSZNAJDER, 1998, p. 137).

Este trabalho optou por uma abordagem qualitativa que tem como fundamento a busca pela proximidade em relação ao objeto estudado de forma a entender os elementos contextuais e suas interrelações com mais profundidade (MAANEN, 1979). A opção pela abordagem qualitativa desta pesquisa deveu-se à constatação de que os estudos existentes sobre negócios sociais são escassos, muitas vezes conduzidos em contextos diversos da realidade brasileira e com limitado potencial explicativo para elucidar as questões que este estudo se propõe a discutir.

O estudo caracteriza-se como uma pesquisa descritiva-exploratória, pois, como explicam Selltiz et al. (1974, p. 59) a pesquisa exploratória "refere-se à descoberta de ideias e intuições", mesclando-se aspectos objetivos e subjetivos nesse tipo de investigação. Já Gil

\footnotetext{
${ }^{8}$ Como explicado no referencial teórico, não há um único conceito para caracterizar os empreendimentos que atuam na lógica de mercado e tem como finalidade a geração de valor socioambiental e valor econômico. No Brasil, os termos mais utilizados são negócios sociais, negócios com impacto social, negócios com propósito social. Neste trabalho, utilizamos negócios sociais e empreendimentos sociais como sinônimos.
} 
(1994) destaca que o caráter descritivo confere ao estudo a finalidade de descrever características de um determinado fenômeno, levantar opiniões e percepções de uma determinada população acerca de um fato, situação ou fenômeno, ou mesmo descobrir associações entre as variáveis que constituem o problema estudado.

O planejamento da pesquisa e a escolha do método devem ser compatíveis com o objetivo da investigação (MILES; HUBERMAN, 1984). Dentre os quatro tipos de objetivos elencados por Selltiz et al. (1974), a pesquisa realizada alinha-se a dois deles: (1) familiarizar-se com o fenômeno ou conseguir nova compreensão deste, frequentemente para poder formular um problema de investigação mais preciso ou criar novas hipóteses; e (2) descrever as características de uma situação, um grupo, um fenômeno ou caso específico, geralmente, para compreender sua natureza e formas de manifestação.

O método utilizado foi estudo de múltiplos casos o qual tem a vantagem de permitir a identificação de similaridades e diferenças (EISENHARDT, 1989; YIN, 2001). De acordo com Yin (2001, p. 32), o estudo de caso constitui "investigação empírica que investiga um fenômeno contemporâneo dentro de seu contexto da vida real, especialmente quando os limites entre o fenômeno e o contexto não estão claramente definidos". Eisenhardt (1989, p.534, tradução nossa) complementa que o estudo de casos é uma estratégia de pesquisa com o foco de "compreender as dinâmicas presentes dentro de uma configuração específica" e pode ser utilizado para atingir vários objetivos: fornecer descrições, gerar hipóteses explicativas e elaborar teorias. Isto se coaduna com os objetivos do estudo Brasil27 que buscava ampliar o conhecimento sobre os empreendimentos sociais brasileiros ao identificar características e padrões que ensejassem elaborar hipóteses e questões de pesquisa sobre a ocorrência do empreendedorismo social e inovação. A unidade de análise, definida como a "forma pela qual organizamos os dados para efeito de análise" (ALVES-MAZZOTTI;GEWANDSZNAJDER, 1998, P. 169) foi o empreendimento social.

Em termos de técnicas de coletas de dados primários na pesquisa Brasil27 foram utilizadas: entrevistas em profundidade, grupos focais e observação. Na continuação do estudo, foco desta tese, foi realizada uma pesquisa documental a partir dos websites dos empreendimentos sociais na internet e dos depoimentos gravados pelos empreendedores. Langley e Abdallah (2011) destacam que o grande desafio da pesquisa qualitativa não está na coleta de dados, mas sim em dar sentido aos dados e informações. Este estudo utilizou- 
se da análise de conteúdo por meio de seleção temática (BARDIN, 1994; VERGARA, 2012). “A análise de conteúdo busca a essência de um texto nos detalhes das informações, dados e evidências disponíveis [...] e é utilizada para descrever tendências, descobrir estilos, identificar características, comparar mensagens, construir padrões e desvendar ideologias" (MARTINS; THEÓPHILO, 2009, p. 98). Os autores sugerem três etapas para realização de uma análise de conteúdo: pré-análise (coleta e organização do material), descrição analítica (definição de unidades de análises e categorias temáticas) e interpretação inferencial (os conteúdos são revelados em função dos propósitos do estudo). Eisenhardt (1989) recomenda que seja feita, primeiramente, uma análise detalhada de cada caso (within-case analysis) para em seguida buscar a identificação de padrões entre os casos (cross-case patterns) por meio de categorias ou dimensões elaboradas a partir do problema de investigação ou da literatura existente.

Com base no referencial teórico apresentado, este estudo elaborou categorias analíticas: (1) classificar os empreendimentos sociais com base na revisão da literatura sobre negócios sociais; (2) dimensões de análise da inovação a partir de referências utilizadas em administração (Manual de Oslo); e categorias de valor socioambiental a partir da literatura de empreendedorismo social, adicionando referências ambientais.

Ao levar em conta que este estudo resgata os resultados da pesquisa Brasil27 para proceder à análise da ocorrência ou não de inovação social nos casos mapeados, a seguir são detalhadas as atividades realizadas desde o início do levantamento.

\section{2 - Descrição da Pesquisa Brasil27}

Os passos da modelagem da investigação, realizada entre março de 2013 a maio de 2014, obedeceu a quatro fases de atividades:

1) Levantamento bibliográfico;

2) Definição do universo da pesquisa e de seleção dos casos;

3) Jornadas do trabalho de campo;

4) Elaboração dos casos descritivos. 


\section{FASE 1: Levantamento bibliográfico}

O referencial teórico da pesquisa Brasil27 foi construído mediante extenso levantamento bibliográfico sobre empreendimentos sociais, tipologia de negócios sociais e negócios inclusivos. Para realizar as interpretações e análises propostas no presente estudo acresceu-se neste referencial teórico-conceitual a bibliografia mais recente sobre geração de valor social e inovação social.

\section{FASE 2: Definição do universo e Seleção dos casos da pesquisa Brasil27}

A segunda fase da pesquisa teve como objetivo estruturar um banco de dados a partir da indicação de negócios sociais por parte dos principais atores do ecossistema. Foram consultadas 23 organizações, a saber: aceleradoras (Artemisia, Quintessa, Nesst, B-Polo), organizações de fomento de empreendimentos sociais (Ashoka, Social Good, Ande, Endeavor, Ande, B-Polo, NegociosSociais.com) e fundos de investimento de impacto e finanças sociais (Vox Capital, Mov/Pragma, Ventura, Kaetê, Bamboo, BRliX, Sitawi, LGT, Bamboo, Village Capital, rede Ande). Esta estratégia de consultas a especialistas e organizações atuantes no ecossistema do empreendedorismo social fez-se necessária em virtude da inexistência de bancos de dados estruturados que agreguem informações sistematizadas sobre quais são os negócios sociais existentes no contexto brasileiro.

Outra estratégia empregada, não apenas para identificar os empreendimentos existentes como também para estimular o debate e a reflexão sobre o fenômeno do empreendedorismo social, foi a de ampliar a publicização da pesquisa. Utilizou-se os recursos das redes sociais (perfis de Facebook e blogs) por meio dos quais foi criada uma rede de colaboradores da Brasil27. Nela, todas as pessoas poderiam indicar negócios que conheciam, bem como acessar as informações que estavam sendo coletadas e participar de debates sobre o tema da pesquisa. Com a combinação das duas ações (consulta e indicações), foram cadastradas 1194 indicações de possíveis negócios sociais de todo o Brasil (vide Tabela 1). 
Tabela 1 - Indicações de Empreendimentos Sociais

\begin{tabular}{|c|c|}
\hline Unidade Federativa & Indicações de negócios sociais \\
\hline $\mathrm{SP}$ & \begin{tabular}{|r|}
398 \\
\end{tabular} \\
\hline RJ & 173 \\
\hline MG & 92 \\
\hline ES & 14 \\
\hline Sudeste & 677 \\
\hline $\mathrm{PE}$ & 46 \\
\hline $\mathrm{BA}$ & 43 \\
\hline CE & 26 \\
\hline PB & 19 \\
\hline $\mathrm{AL}$ & 14 \\
\hline $\mathrm{PI}$ & 5 \\
\hline $\mathrm{MA}$ & 4 \\
\hline SE & 1 \\
\hline Nordeste & 158 \\
\hline $\mathrm{RS}$ & 58 \\
\hline SC & 35 \\
\hline PR & 40 \\
\hline Sul & 133 \\
\hline MS & 56 \\
\hline $\mathrm{GO}$ & 34 \\
\hline MT & 14 \\
\hline DF & 23 \\
\hline Centro_Oeste & 127 \\
\hline PA & 17 \\
\hline TO & 13 \\
\hline AM & 12 \\
\hline $\mathrm{RO}$ & 13 \\
\hline $\mathrm{RN}$ & 7 \\
\hline $\mathrm{AC}$ & 6 \\
\hline AP & 6 \\
\hline $\mathrm{RR}$ & 3 \\
\hline Norte & 77 \\
\hline Sem Informação & 22 \\
\hline Total & 1194 \\
\hline
\end{tabular}

Fonte: Elaborada pela autora

O próximo passo da seleção dos casos envolveu a filtragem das indicações pela equipe de pesquisa ${ }^{9}$. Foram eliminadas as repetições de indicações e passou-se a verificar a existência dos empreendimentos mediante a busca de sites institucionais, contatos telefônicos e por correio eletrônico. Os casos confirmados foram organizados conforme o estado de localização e passaram a ser caracterizados considerando-se três dimensões: natureza, finalidade e funcionamento do empreendimento; as quais foram empregadas como critérios de escolha para o trabalho de campo.

\section{1) Natureza do Empreendimento}

O negócio social não deveria configurar-se como uma iniciativa de responsabilidade de uma corporação, como acontece frequentemente com os projetos de investimento social de empresas; ou com a criação de áreas empresariais que procuram atuar junto à chamada

\footnotetext{
${ }^{9}$ A equipe de pesquisa foi formada pelas Profas. Dras. Graziella Maria Comini e Rosa Maria Fischer e os pesquisadores Pedro Henrique G. Vitoriano e Fábio A. Serconek.
} 
"base da pirâmide" do mercado consumidor. Isto porque o foco da pesquisa era a identificação de negócios sociais que gozassem de autonomia jurídica e administrativa; dedicados a desenvolver produtos e serviços voltados para população em situação de vulnerabilidade e/ou voltados para a solução de problemas ambientais.

\section{2) Finalidade do Empreendimento}

A missão do negócio social, isto é, o objetivo principal de sua atuação deveria ser de natureza socioambiental e suas atividades operacionais e técnicas deveriam estar alinhadas com a consecução desse objetivo. Os segmentos de baixa renda, ou em situação de vulnerabilidade social da população, deveriam constituir a cadeia de valor do empreendimento ocupando os possíveis papéis de proprietários, fornecedores ou clientes/usuários/consumidores.

\section{3) Funcionamento do Empreendimento}

Outro critério adotado como filtro junto ao universo de empreendimentos indicados era de que o selecionado deveria ter realizado, pelo menos, uma operação formal. Isto porque a pesquisa não pretendia estudar startups, mas sim negócios estruturados ou em fase de consolidação do seu funcionamento pleno. Como muitos empreendimentos sociais só conseguem iniciar suas atividades por meio da obtenção de recursos não reembolsáveis (doações, financiamentos a fundo perdido, capital semente), foi adicionado o critério de que, no momento da pesquisa, o negócio em estudo tivesse, pelo menos, $50 \%$ da receita provenientes diretamente de suas operações. A diminuição da dependência do empreendimento social de doações é um indicador importante da sua capacidade de sustentabilidade financeira e da possibilidade de afirmar-se quando exposto à competitividade da lógica de mercado.

A partir dessa análise, foram eleitos para o levantamento de dados primários em campo de um a três casos por estado da Federação. Nessa escolha, foram priorizados os empreendimentos sociais que ainda não tinham sido objeto de estudos anteriores. Foi realizado o contato inicial com os empreendedores convidados a participar da Brasil27 e houve elevado interesse, pois nenhum deles recusou-se a participar do levantamento. 


\section{FASE 3: JORNADAS DO TRABALHO DE CAMPO}

Durante o trabalho de campo da Brasil27, os pesquisadores procuraram visitar as localidades onde estavam inseridas as operações dos negócios sociais estudados para conhecer seu funcionamento, seus gestores e seu entorno.

Essas visitas tomaram a forma de Learning Expeditions, ou seja, jornadas de trabalho e aprendizagem nas quais, além dos contatos com os empreendedores e gestores do negócio, eram realizadas reuniões para as quais se convidavam universitários e pessoas da região interessadas no tema do empreendedorismo social. Nesses grupos focais apresentava-se o negócio foco de estudo naquela localidade, monitorando-se um debate acerca de suas características. Em algumas cidades como Goiânia, Campinas, São Paulo, São José do Rio Preto, Brasília, os pesquisadores participaram de seminários organizados por entidades estudantis para disseminar conceitos sobre negócios sociais e apresentar a pesquisa em realização. Desse modo, buscava-se disseminar os conceitos e as proposições do empreendedorismo social e coletar opiniões e percepções sobre o tema e sobre o caso em estudo, que pudessem enriquecer a posterior análise dos dados. A Tabela 2 elenca os workshops realizados e o respectivo número de participantes.

A visita ao empreendimento social era realizada em dois dias e contava com participação de dois pesquisadores e um cinegrafista. No primeiro dia, eram realizadas entrevistas semiestruturadas com os empreendedores e principais gestores para conhecer o negócio, detalhar seu histórico, compreender suas operações, e, quando possível, ter acesso aos clientes/beneficiários/consumidores. No segundo dia, era gravado um vídeo com os fundadores narrando o propósito do negócio, desafios e principais dificuldades para consolidação do empreendimento social. 
Tabela $\mathbf{2}$ - Workshops / grupos focais realizados

\begin{tabular}{llc} 
Cidade & Local & Participantes \\
São Paulo & ICE & 8 \\
\hline Campinas & UNICAMP & 40 \\
\hline São Paulo & ESPM & 100 \\
\hline Porto Alegre & Colégio La Salle & 8 \\
\hline Florianópolis & UFSC & 8 \\
\hline Curitiba & Nex Coworking & 9 \\
\hline Salvador & UFBA & 8 \\
\hline Maceió & E-Gerencial Escola de Gestão & 11 \\
\hline Recife & Porto Digital & 5 \\
\hline Campina Grande & UFCA & 12 \\
\hline Manaus & Alternativo Petrópolis & 10 \\
\hline Porto Velho & Sebrae & 34 \\
\hline Brasilia & Hotel Mestre D'armas & 70 \\
\hline Campo Grande & SEBRAE & 12 \\
\hline São José do Rio Preto & UNESP & 150 \\
\hline Goiânia & $19 \circ$ Congresso Nacional de Jovens empreendedores \\
\hline Goiânia & AlESEC - Youth to business & 80 \\
\hline Vitória & UFES & 5 \\
\hline Rio de Janeiro & PUC-RJ & 638 \\
\hline \hline Total & & 53 \\
\hline & & 150 \\
\hline
\end{tabular}

Fonte: Elaborada pela autora

\section{FASE 4: DESCRIÇÃO DOS CASOS}

Ao final de cada jornada, os pesquisadores sintetizavam os principais pontos levantados, encaminhavam para os entrevistados para obter a validação e publicavam o relato descritivo no blog da pesquisa (www.projetobrasil27.com.br) e no caderno online do jornal Folha de São Paulo denominado Empreendedor Social (os links estão disponíveis no Anexo A).

A transparência dos dados e publicização do relato descritivo dos negócios sociais estavam alinhados e coerentes com o principio norteador da pesquisa de contribuir para a consolidação do campo de negócios sociais ao longo do processo e não apenas no final do levantamento. A pesquisa Brasil27 obteve uma participação efetiva no Facebook (www.facebook.projetobrasil27) com um grupo formado por mais de 1900 pessoas. Também teve destaque na mídia, sendo veiculada 25 vezes na mídia impressa (Anexo B apresenta a relação das publicações sobre o projeto). 


\section{3 - Classificação dos Empreendimentos}

Na visita de campo, tornou-se evidente que os negócios sociais são organizações híbridas, porém com um espectro muito diversificado em seus modus operandi: algumas se assemelham a empresas tradicionais, com maior ênfase no mercado; outros negócios pautam sua atuação com uma lógica similar a de organizações da sociedade civil (independentemente de sua nomenclatura jurídica) com maior preocupação com a geração de valor socioambiental. Este resultado da pesquisa indicou a necessidade de mapear esta pluralidade de atuação e, para tanto, no presente estudo foi construída uma régua a partir do

Quadro 3 apresentado no referencial teórico, atribuindo-se um score a cada fator (vide Tabela 3).

Dessa forma, foi possível classificar os 27 empreendimentos analisados em um Continuum de Tipologia de Negócios Sociais, o qual permitiu um entendimento inicial do posicionamento destes negócios. Este posicionamento é importante para identificar se há uma possível relação entre geração de valor socioambiental, inovação e empreendimentos sociais, ou seja, se a finalidade/forma de uma inovação depende da lógica de atuação do empreendimento social.

A partir dos escores obtidos, é possível plotar os 27 casos em uma régua que varia de -10 a 10 com objetivo de identificar sua lógica de atuação (Figura 6).

Figura 6 - Lógica de Atuação dos Negócios Sociais

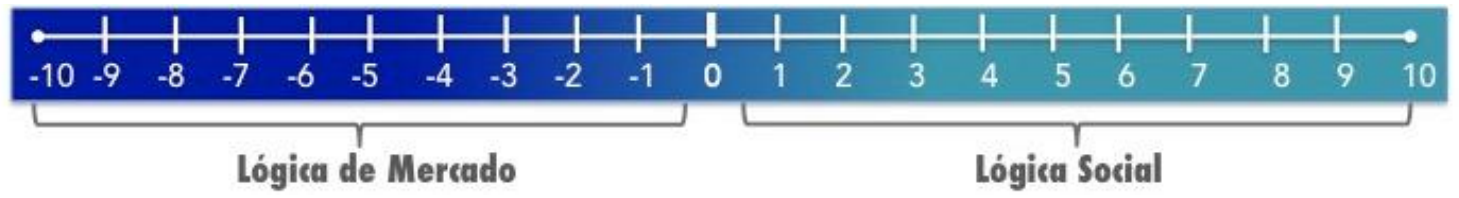

Fonte: elaborado pela autora 
Tabela 3 - Fatores para Classificação dos Empreendimentos Sociais

\begin{tabular}{|c|c|c|c|}
\hline & Fatores & Lógica de Mercado & Lógica Social \\
\hline \multirow{4}{*}{$\frac{\text { 岁 }}{\frac{2}{\frac{1}{2}}}$} & Objetivo principal & $\begin{array}{l}\text { Aproveitar uma oportunidade de } \\
\text { mercado Score (-1) }\end{array}$ & $\begin{array}{l}\text { Resolver um problema } \\
\text { socioambiental. Score (1) }\end{array}$ \\
\hline & Oferta & $\begin{array}{l}\text { Bens e serviços voltados para o } \\
\text { consumo da população Score }(-1)\end{array}$ & $\begin{array}{l}\text { Bens e serviços voltados para } \\
\text { necessidades básicas da população } \\
\text { ou que conservem a biodiversidade. } \\
\text { Score (1) }\end{array}$ \\
\hline & Intencionalidade & $\begin{array}{l}\text { Geração de valor social é um } \\
\text { componente importante, porém } \\
\text { não central. Score }(-1)\end{array}$ & $\begin{array}{l}\text { Geração de valor socioambiental é o } \\
\text { core business do negócio. Score (1) }\end{array}$ \\
\hline & Escala & Fator relevante Score $(-1)$ & $\begin{array}{l}\text { Replicabilidade é mais relevante que } \\
\text { a escalabilidade. Score (1) }\end{array}$ \\
\hline \multirow{3}{*}{ 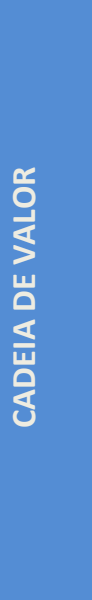 } & Clientes & $\begin{array}{l}\text { Os clientes pertencem a diversas } \\
\text { classes sociais Score }(-1)\end{array}$ & $\begin{array}{l}\text { Predominantemente segmentos da } \\
\text { população que estão em situação de } \\
\text { maior vulnerabilidade social. Score } \\
\text { (1) }\end{array}$ \\
\hline & Fornecedores & $\begin{array}{l}\text { Os critérios para escolha são } \\
\text { preço e qualidade Score (-1) }\end{array}$ & $\begin{array}{l}\text { Procura-se contratar segmentos da } \\
\text { população que estão em situação de } \\
\text { maior vulnerabilidade social. Score } \\
\text { (1) }\end{array}$ \\
\hline & Colaboradores & $\begin{array}{l}\text { Não há nenhuma prioridade na } \\
\text { contratação. Score }(-1)\end{array}$ & $\begin{array}{l}\text { Prioridade para segmentos da } \\
\text { população que estão em situação de } \\
\text { maior vulnerabilidade social. Score } \\
\text { (1) }\end{array}$ \\
\hline 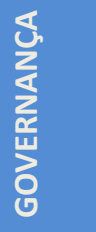 & $\begin{array}{l}\text { Processo } \\
\text { decisório }\end{array}$ & $\begin{array}{l}\text { Não há mecanismos institucionais } \\
\text { para participação coletiva. Score } \\
(-1)\end{array}$ & $\begin{array}{l}\text { Há mecanismos institucionais para } \\
\text { participação coletiva das } \\
\text { comunidades com as quais o } \\
\text { empreendimento atua. Score (1) }\end{array}$ \\
\hline \multirow{3}{*}{ 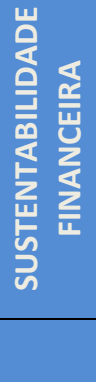 } & $\begin{array}{l}\text { Distribuição de } \\
\text { lucro }\end{array}$ & $\begin{array}{l}\text { Distribuição de dividendos. Score } \\
(-1) \text { Score }(-1)\end{array}$ & $\begin{array}{l}\text { Lucro é totalmente investido no } \\
\text { empreendimento. Score (1) }\end{array}$ \\
\hline & Valor econômico & $\begin{array}{l}\text { Todos os recursos são } \\
\text { provenientes de vendas de } \\
\text { produtos e serviços. Score }(-1)\end{array}$ & $\begin{array}{l}\text { Depende de doações e/ou } \\
\text { contribuições institucionais para } \\
\text { desenvolver sua atividade principal. } \\
\text { Score (1) }\end{array}$ \\
\hline & Total & -10 & 10 \\
\hline
\end{tabular}

Fonte: Elaborado pela autora. 


\section{4 - Análise das Inovações}

Todos os resultados obtidos nas learning journeys (vídeos e descritivos dos casos) foram utilizados como materiais de consulta para identificar e analisar a ocorrência de inovações sociais nos casos mapeados pela Brasil27.

Os produtos e serviços criados pelos empreendimentos sociais selecionados foram analisados em quatro dimensões: finalidade (impacto desejado); forma (tipo de inovação); profundidade (magnitude da inovação) e abrangência (difusão da inovação), conforme apresentado no item 2.6.1 Recorte analítico para Análise de Inovação Social.

Um primeiro recorte de análise procurou identificar se há alguma relação entre os diferentes tipos de empreendimentos sociais (lógica de mercado x lógica social) e suas inovações (Figura 7). O estudo pretendeu identificar se negócios sociais com lógica de mercado tendem a desenvolver inovações de produtos/serviços ou mercadológicas e se, por outro lado, negócios sociais mais voltados para lógica social tendem a ter mais preocupação com inovações em processos e organizacional.

Um segundo recorte analítico do empreendimento social está vinculado ao valor socioambiental desejado. A análise do valor socioambiental foi feita classificando a finalidade dos empreendimentos sociais em oito categorias, conforme apresentado no item 2.4.1 do referencial teórico: aumento de capital físico, capital humano, capital produtivo, capital social, diminuição de custos de transição, cidadania, capital natural, contribuição para uma economia de baixo carbono e reuso de materiais. 
Figura 7 - Matriz Analítica sobre Tipos de Inovação

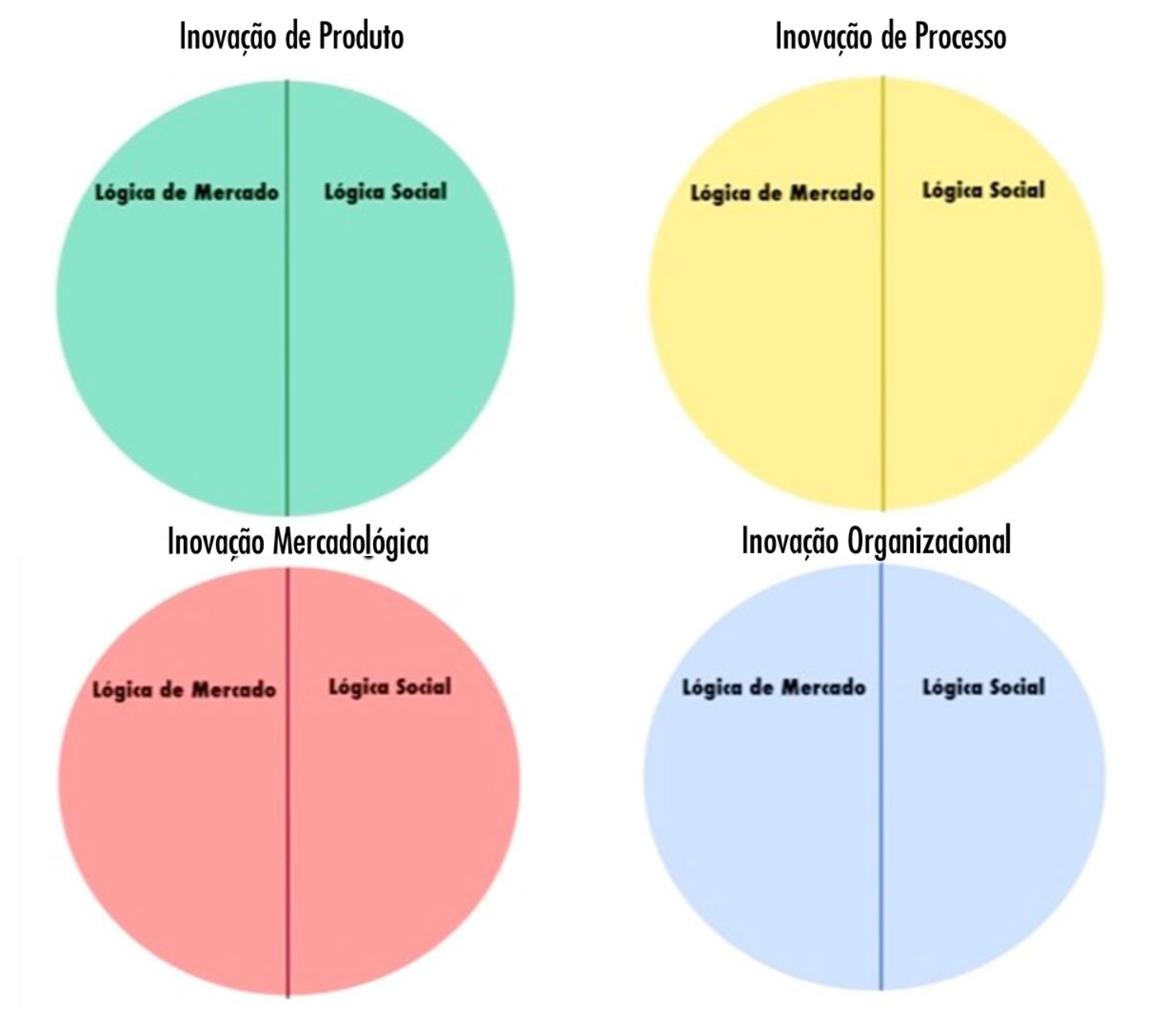

Fonte: elaborada pela autora

Como um empreendimento social pode gerar valor socioambiental em mais de uma categoria de forma intencional (direta) ou colateral (indireta), foi necessário classificar as contribuições de acordo com sua natureza:

(i) Efeito primário: geração de valor socioambiental diretamente relacionado à atividade central do empreendimento, o efeito materializa a missão do empreendimento e é um resultado direto do empreendimento. (Peso 2);

(ii) Efeito secundário: geração de valor socioambiental obtida de forma indireta, expressa um efeito colateral positivo das atividades desenvolvidas pelo empreendimento, constituindo uma externalidade positiva e um resultado indireto. (Peso 1). 
O número de pontos de um empreendimento indica o seu potencial de impacto: quanto mais elevado o número, maior será o potencial de impacto. A figura 8 exemplifica esta relação: o Caso 8 gera mais valor socioambiental do que o caso 9. Os valores calculados são plotados em uma matriz que diferencia empreendimentos com lógica social e lógica de mercado para avaliar se é possível inferir algum tipo de relação entre lógica de atuação de empreendimento e geração de valor socioambiental. No exemplo apresentado na Figura 8, os negócios sociais com uma orientação mais social tendem a gerar maior valor socioambiental do que os negócios sociais com lógica de mercado.

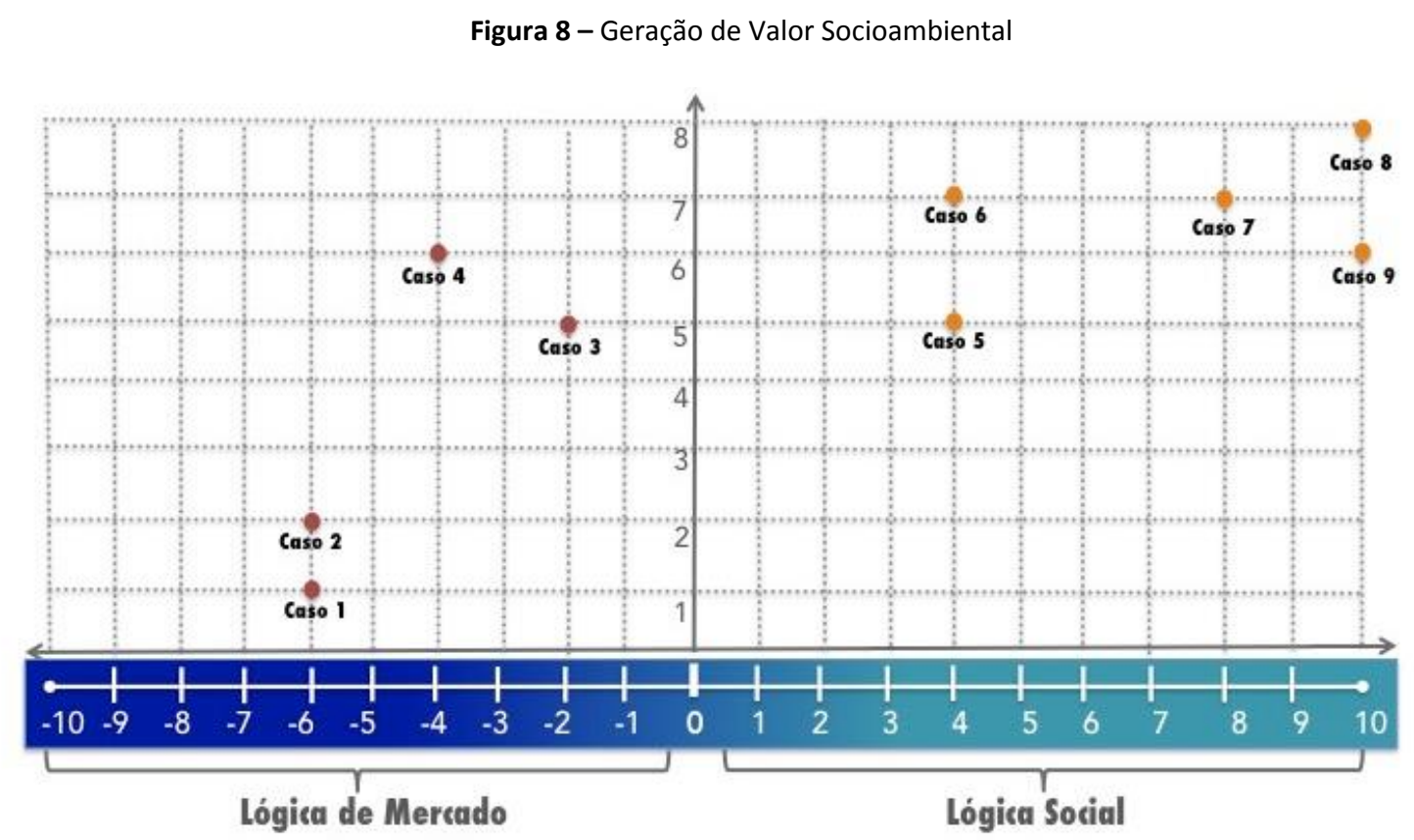

Fonte: elaborada pela autora

É esperado que empreendimentos sociais, que desejam provocar mudanças sociais profundas, gerem valor socioambiental em mais de uma categoria. Portanto, buscarão mais de uma forma de inovação: em produtos e serviços, no posicionamento mercadológico, em características dos processos, dos procedimentos e da própria organização. Dessa forma, foi realizada uma análise para verificar a relação entre geração de valor socioambiental e as formas de inovação apresentadas em cada caso deste estudo.

Por fim, foi feita uma análise do resultado da inovação: até que ponto as inovações desenvolvidas pelos negócios sociais estudados estão provocando, ou fortalecendo, mudanças sociais e econômicas (inovações incrementais); ou estão contribuindo para 
transformações mais profundas (inovações institucionais e disruptivas)? Para isso, foi elaborada uma matriz para plotar os 27 casos relacionando-os às dimensões profundidade e abrangência, como mostra a Figura 9.

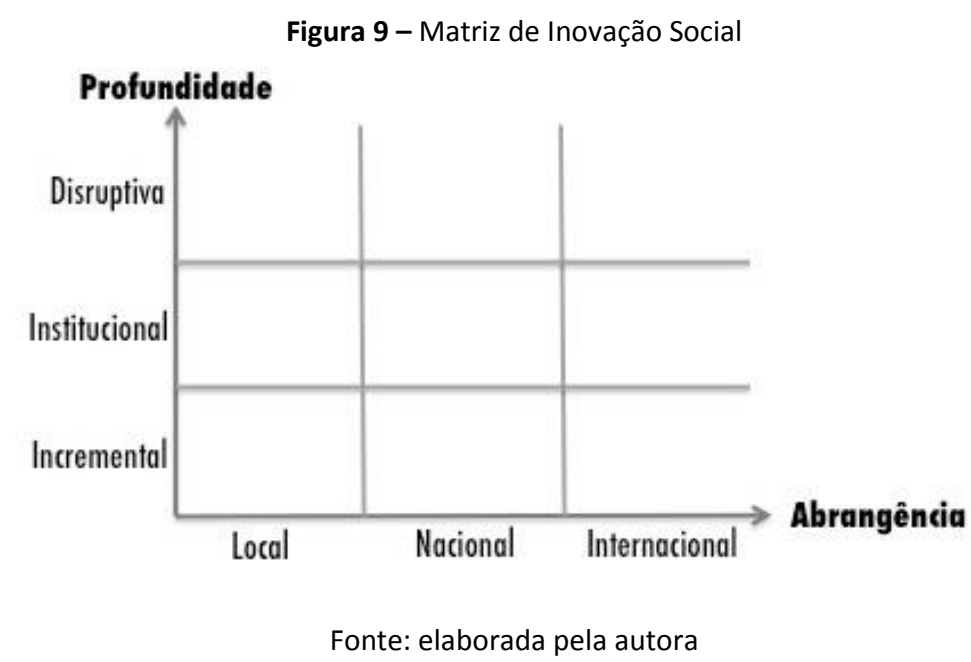

No próximo capítulo, é apresentada a primeira etapa de análise detalhada de cada caso within-case analysis (EISENHARDT, 1989). São descritos os empreendimentos mapeados pela Brasil27, separados por região geográfica e classificados de acordo com sua lógica de atuação. São destacadas as inovações observadas (tipo, abrangência, profundidade) em cada empreendimento, bem como os resultados socioambientais diretos e indiretos de suas operações. Em seguida, são feitas análises agregadas dos 27 casos, constituindo a segunda etapa de análise para a identificação de padrões entre os casos - cross-case patterns (EISENHARDT, 1989). 


\section{4 - Descrição dos Casos}

\section{1 - Região Sul}

\subsection{1 - Justa Trama (RS)}

A Justa Trama é uma cooperativa central, da qual fazem parte seis cooperativas nas cinco regiões do Brasil (Figura 10). Suas atividades iniciaram-se em 2004, quando um grupo de cooperativas localizadas em SP, PR, SC e RS recebeu um pedido de 60 mil ecobags, destinadas ao Fórum Social Mundial de 2005, realizado na cidade de Porto Alegre. Como a experiência deu certo, as cooperativas decidiram se unir e atuar de forma integrada na cadeia de valor de produção que emprega o algodão ecológico e é norteada pelos valores e princípios da Economia Solidária. Estabeleceram como missão "Articular e integrar os empreendimentos da cadeia produtiva da fibra ecológica através do plantio, transformação, produção e comercialização, promovendo a economia solidária, a sustentabilidade, a agroecologia, o comércio justo, o consumo consciente, a preservação do meio ambiente e a distribuição justa de renda para seus associados e a sociedade em geral."

A Justa Trama atende empresas que compram grandes volumes de brindes coorporativos e também comercializa seus produtos para consumidores finais em lojas próprias e feiras. Busca atingir o consumidor final por meio de mídias sociais, blogs especializados em produtos ecológicos e em iniciativas da Economia Solidária, além de contar com a divulgação "boca a boca". A cooperativa central possui três lojas, duas em Porto Alegre e uma em Itajaí, e também comercializa seus produtos em feiras tradicionais.

O produto apresenta valor ambiental por ser produzido com algodão ecológico, o que tem um grande apelo entre o nicho de pessoas que buscam o consumo consciente. Além disso, são vendidos a preços baixíssimos se comparados aos de outras marcas que utilizam o mesmo material. Quando Nelsa Nespolo, presidente da Justa Trama, é indagada sobre o motivo de não cobrar preços mais elevados pelos seus produtos feitos com materiais superiores, ela afirma: "quem produz nossos produtos deve ter a condição financeira de adquiri-los. Portanto, fabricamos um produto para todos e cobramos um preço que consideramos ser o justo". 
Figura 10 - Cooperativas envolvidas na Justa Trama

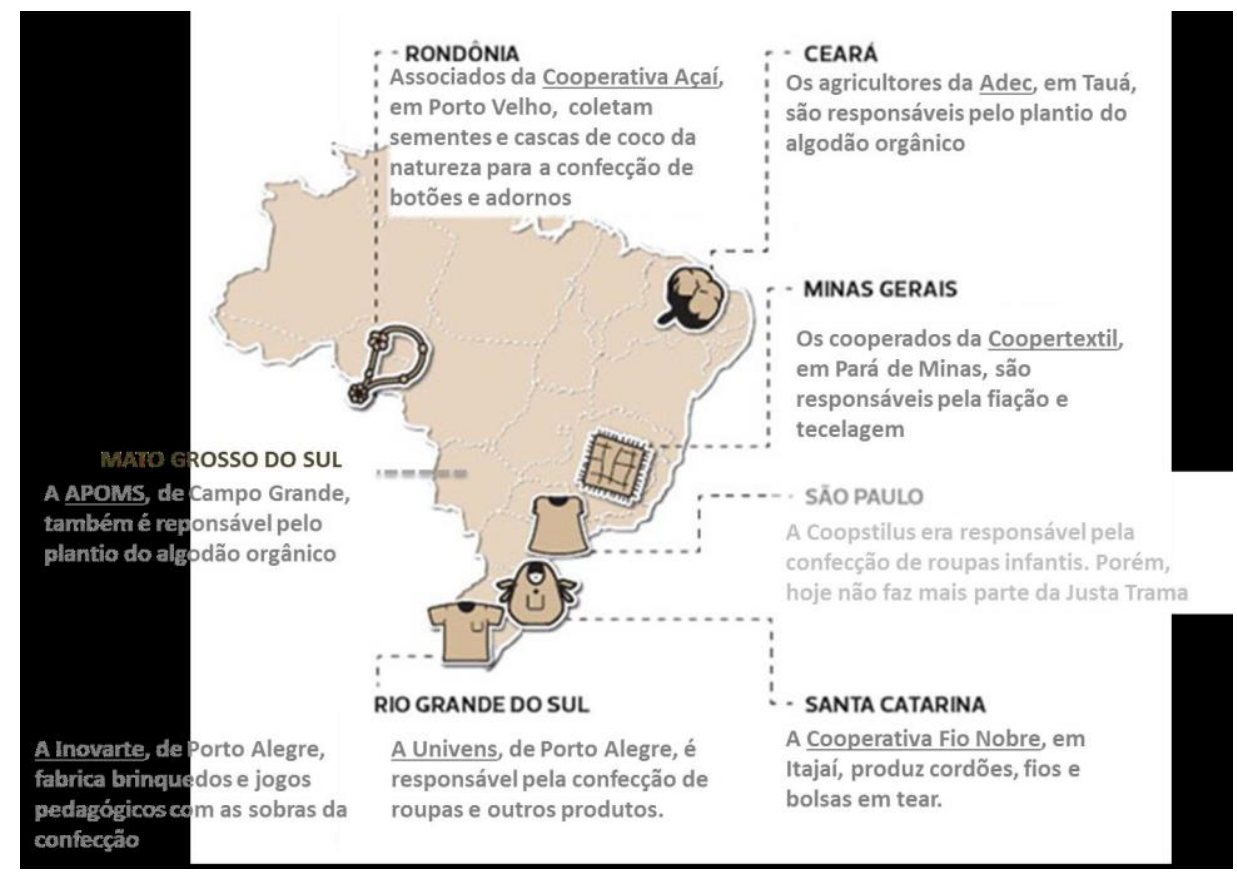

Fonte: $\underline{w w w . p r o j e t o b r a s i l 27 . c o m . b r}$

A Justa Trama tem uma estrutura bem enxuta, tendo apenas uma pessoa trabalhando exclusivamente nas atividades administrativas. Todos os outros colaboradores fazem parte de alguma das cooperativas participantes. Investimentos altos para a compra de maquinário são realizados com fundos obtidos por meio de editais públicos. Os principais custos da cadeia como um todo são com a movimentação de materiais e com a produção. As reuniões gerais também representam uma despesa significativa, embora considerada essencial. Pelo menos duas vezes ao ano, os presidentes de todas as cooperativas se reúnem presencialmente para definirem estratégias, resolverem problemas, levantar necessidades e se apoiarem mutuamente, de modo a funcionarem como uma rede.

Os dados levantados permitem classificar a Justa Trama como um empreendimento social com uma lógica de atuação com muita ênfase no social, obtendo uma pontuação de 6 (de um total que varia de -10 a 10), vide na tabela 4 , apresentada seguir. 
Tabela 4 - Posicionamento do Empreendimento Social - Justa Trama

\begin{tabular}{|c|c|c|c|}
\hline Fotores & LGginade Nered & $\begin{array}{l}\text { Justa Trenes } \\
\text { (ES) }\end{array}$ & Lógirasodid \\
\hline Objetivo principd & Aproveitar uma oportunidade de mercodo & 1 & Resolver um problemo socioontiental \\
\hline Ofenta & $\begin{array}{l}\text { Bens e serviços wolitodos pero o consumo } \\
\text { da popdoçö }\end{array}$ & -1 & $\begin{array}{l}\text { Bens e senvicos voltodos para necessidades bósiens e/ou } \\
\text { que conservem a biodiversidade }\end{array}$ \\
\hline Intenóondidode & $\begin{array}{l}\text { Geroçóo de volor socidl é um componente } \\
\text { importante, porém nōo central }\end{array}$ & 1 & Geropbo de valor social te o core businessdo negbcio \\
\hline Escalh & Fator relevonte & 1 & Replicabilidode é mais relevante que a escolabilidode \\
\hline Clientes & Os diemtes pertencem a diversos classes socidis & 1 & $\begin{array}{l}\text { Predaminantemente segmeat os da populaçāo que estôo em } \\
\text { situoção de meior vulherabilidode }\end{array}$ \\
\hline Fornecedores & Os critérios para escolha sõo preço e qualidade & 1 & 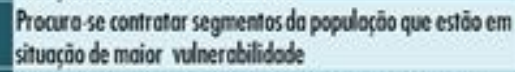 \\
\hline Colaboradores & Näo há menhuma prioridode na contretoçōo & 1 & 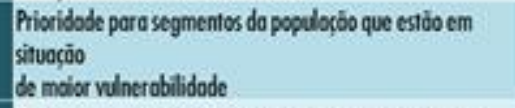 \\
\hline Processo decósório & $\begin{array}{l}\text { Möo há meconismos institucienocis para } \\
\text { perticipoctóo colefivo }\end{array}$ & 1 & $\begin{array}{l}\text { Há meconismos instituxionois para participoçōo coletiva } \\
\text { dos comunidades com as quais o empreendimento atvo }\end{array}$ \\
\hline Distribuiçōo de lucro & Distribuiç̧o de dividendos. & 1 & Lucroé totalmente imvestido \\
\hline Valor Ecoenbinico & $\begin{array}{l}\text { Todos es recursos scio provenientes } \\
\text { de vendas de produtos e servicos }\end{array}$ & 1 & $\begin{array}{l}\text { Depende de doaç̄ös e colaboroçōes institucionois paro } \\
\text { desenwolver suo atividode principd }\end{array}$ \\
\hline Totd & & 6 & \\
\hline
\end{tabular}

Fonte: elaborada pela autora

As inovações implementadas pela Justa Trama podem ser observadas em três categorias: mercadológica (forma de precificação de seus produtos), processo (interligação de todos os atores da cadeia de produção) e organizacional (aliança estratégica de seis cooperativas em um modelo de negócios). A abrangência da inovação é nacional, visto que atua com cooperativas nas cinco regiões do Brasil. Pode-se dizer que a inovação implementada tem um caráter institucional, pois reconfigura o mercado de produção de algodão ecológico mostrando a viabilidade da atuação conjunta de organizações de economia solidária.

Em termos de geração de valor socioambiental, considera-se que os resultados diretos produzidos pela Justa Trama são: o incremento da geração de renda dos cooperados pela inserção em uma cadeia de valor e seu acesso a bens de produção pelo fato de obterem investimentos coletivos (capital produtivo). Destacam-se, ainda, os resultados de conservação da biodiversidade pela produção ecológica do algodão empregada em suas confecções (capital natural) e a eliminação de intermediários no processo de comercialização (custos de transação). De forma indireta, deve-se destacar o aumento do capital social por meio da criação de uma rede de colaboração solidária e aumento da consciência ambiental pelo estímulo ao consumo de algodão ecológico. Observou-se ainda um sentimento de empoderamento e de autoestima elevada dos cooperados, uma vez que a cooperativa central trabalha com fornecedores e clientes que compartilham dos seus valores e ideias, sem haver necessidade de estabelecer relações comerciais com organizações orientadas por outros princípios e padrões culturais. 


\subsection{2 - Meritt (SC)}

A Meritt é uma empresa de tecnologia voltada para a área de educação. Foi criada, em 2011, por Alexandre Oliveira e Ricardo Fritsche que desenvolveram um sistema de gestão de informações escolares para escolas públicas e privadas. O software é alimentado com dados coletados nas avaliações feitas pelo governo federal - como as notas obtidas pelos alunos em avaliações como o Enem - e em informações colhidas no Censo Escolar, realizado periodicamente pelo Ministério da Educação. Essas informações são transformadas em dados que possibilitam o planejamento de ações focadas e com maior chance de êxito nos mais diversos níveis do sistema educacional: do professor, do diretor, da escola, dos secretários municipais e estaduais, ou até dos técnicos do Ministério da Educação.

O processo de transformação de dados-informações-conhecimento configura a proposta de valor da Meritt. Além da prestação de serviços para secretarias municipais e escolas, a organização disponibiliza dois sites de acesso público na internet - o QEdu e o Portal Ideb. Este empreendimento foi acelerado pela Artemísia e recebeu recursos financeiros da Fundação Lemann, entidade criada pelo empresário Jorge Paulo Lemann e dedicada a iniciativas na área de educação.

Os dados levantados permitem classificar a Meritt como um empreendimento com uma lógica de atuação com muita ênfase no mercado, obtendo uma pontuação de -6 (de um total máximo de -10), vide na tabela 5. 
Tabela 5 - Posicionamento do Empreendimento Social - Meritt

\begin{tabular}{|c|c|c|c|}
\hline Fotores & Lógica de Mercodo & $\begin{array}{l}\text { Meriit } \\
\text { (SC) }\end{array}$ & Lógica Socid \\
\hline Objefivo principal & Aproveitar uma oportunidade de mercado & -1 & Resolver um problema socioambiental \\
\hline Oferta & $\begin{array}{l}\text { Bens e serviços voltados para o consumo } \\
\text { da populaçấo }\end{array}$ & 1 & $\begin{array}{l}\text { Bens e servicos voltados para necessidades básicas e/ou } \\
\text { que conservem a biodiversidade }\end{array}$ \\
\hline Intencionalidade & $\begin{array}{l}\text { Geração de valor social é um componente } \\
\text { importante, porém não central }\end{array}$ & -1 & Geração de valor social é o core business do negócio \\
\hline Escala & Fator relevante & -1 & Replicabilidade é mais relevante que a escalabilidade \\
\hline Clientes & $\begin{array}{l}\text { Os dientes pertencem a diversas dasses } \\
\text { sociais }\end{array}$ & -1 & $\begin{array}{l}\text { Predominantemente segmentos da população que estão em } \\
\text { situação de maior vulnerabilidade }\end{array}$ \\
\hline Fornecedores & $\begin{array}{l}\text { Os critérios para escolha são preço e } \\
\text { qualidade }\end{array}$ & -1 & $\begin{array}{l}\text { Procura-se contratar segmentos da população que estão em } \\
\text { situacāōo de maior vulnerabilidade }\end{array}$ \\
\hline Colaboradores & Não há nenhuma prioridade na contrataçāo & -1 & $\begin{array}{l}\text { Prioridade para segmentos da população que estão em situaçāo } \\
\text { de maior vulnerabilidade }\end{array}$ \\
\hline Processo decisório & $\begin{array}{l}\text { Não há mecanismos institucionais para } \\
\text { participacãóo coletiva }\end{array}$ & -1 & $\begin{array}{l}\text { Há mecanismos institucionais para participação coletiva } \\
\text { das comunidades com as quais } 0 \text { empreendimento atua }\end{array}$ \\
\hline Distribuic̣ōo de loro & Distribuição de dividendos. & -1 & Lucro é totalmente investido \\
\hline Valor Econômico & $\begin{array}{l}\text { Todos os recursos são provenientes } \\
\text { de vendas de produtose servicios }\end{array}$ & 1 & $\begin{array}{l}\text { Depende de doaçōes e colaboraçōes institucionais para } \\
\text { desenvolver sua atividade principal }\end{array}$ \\
\hline Total & & -6 & \\
\hline
\end{tabular}

Fonte: elaborada pela autora

A inovação implementada pela Meritt configura-se basicamente como de produto, visto que criou um software de gestão adaptado para o contexto educacional. A abrangência da inovação é nacional levando em conta que utiliza dados brasileiros do sistema de educação e é uma plataforma digital que permite amplo acesso. A profundidade pode ser considerada incremental, pois gera impacto ao mitigar as falhas de atuação do aparato do Estado nas atividades do sistema educacional, mas não chega a reconfigurar a indústria da Educação.

Em termos de geração de valor socioambiental, contribui para melhoria da qualidade da educação brasileira, gerando um benefício indireto no que concerne ao incremento do capital humano. Em entrevista para Revista Exame (2013), Raph Alves, diretor do Núcleo da Escola de Formação da rede estadual de ensino de Goiás comentou sobre o portal do Meritt: "As informações do portal estão ajudando a Secretaria da Educação a implantar uma política de meritocracia entre os profissionais da educação no município"., e. "Identificamos quais são as melhores escolas, que ganham recursos para investir em novos projetos, e aquelas em que há problemas de aprendizagem, para que possamos encontrar uma solução." 


\subsection{3 - Terra Nova (PR)}

Terra Nova é a primeira empresa brasileira focada na resolução de conflitos fundiários em propriedades privadas. Foi fundada, em 2001, por André Albuquerque em Curitiba/PR. Sua principal atividade consiste na articulação de todos os stakeholders envolvidos na questão: governo, proprietários e ocupantes. Antes de iniciar o processo de articulação, a equipe da empresa busca conhecer as condições da ocupação e ganhar a confiança da comunidade. Muitos dos ocupantes tiveram que pagar a posseiros pelo pedaço de terra que ocupam, o que é considerado ilegal e irregular. Porém, na percepção das pessoas, configura uma aquisição válida. Assim, convencer a comunidade da importância de se regularizar a propriedade do espaço ocupado por suas moradias não é tarefa fácil. Uma das ações essenciais é o desenvolvimento de lideranças locais que possam apoiar o trabalho de convencimento e esclarecimento da equipe da Terra Nova e assegurar o sucesso de todo o processo.

A obtenção do título regularizado da propriedade da terra constitui-se um grande valor para o morador, que tem o seu bem valorizado. Além disso, a área ocupada passar a receber os melhoramentos públicos como: arruamento, endereçamento postal e serviços básicos.

Os ocupantes não são os únicos beneficiados por este processo de regularização. O governo, por sua vez, após a resolução do conflito, tem a possibilidade de investir em infraestrutura básica, como energia, água, esgoto e asfalto, além de iniciar a arrecadação de impostos.

O proprietário consegue vender sua terra aos ocupantes, livrando-se do passivo e da situação ambígua da ocupação, na qual o proprietário não tem condição de utilizar sua propriedade ou vendê-la para terceiros. Sem essa regularização, os impostos continuam a incidir sobre a terra e, muitas vezes, mesmo com ordem judicial, o proprietário não consegue a desocupação. Por estes motivos, mesmo obtendo preços um pouco abaixo do mercado, a venda da terra representa uma solução satisfatória para o proprietário.

Uma vez feito o acordo, a Terra Nova gerencia os contratos e recebe o pagamento de cada família em pequenas parcelas mensais, durante um período de cinco a 10 anos. A gestão de contratos e dos pagamentos é uma importante tarefa da empresa. A cobrança, apesar de ser 
uma atividade-chave, não é complicada, pois a inadimplência é baixa e a empresa capacita agentes comunitários para realizarem essa atividade.

O mecanismo de monetização da Terra Nova é simples e direto. Os ocupantes pagam o valor negociado aos proprietários de forma parcelada e a Terra Nova fica com um pequeno percentual desta quantia ou ganha um valor fixo pelo lote. Mesmo com a possibilidade de dividir os lucros entre os shareholders, até o momento a empresa decidiu reinvestir todo o lucro para aumentar sua capacidade de operação e a perspectiva de criar impacto social nas comunidades.

Apesar do mecanismo de monetização ser simples, há um grande desafio relacionado ao capital. Para se iniciar o processo de regularização fundiária, é necessário contar com os recursos financeiros necessários para desenvolver o projeto arquitetônico e urbanístico e realizar o levantamento planialtimétrico. A Terra Nova viabiliza este investimento por meio da negociação de seus recebíveis com bancos.

Os dados levantados permitem classificar a Terra Nova como um empreendimento social com uma lógica de atuação com maior ênfase no social, obtendo uma pontuação de 6 (de um total que varia de -10 a 10$)$, vide na tabela 6 , a seguir.

Tabela 6 - Posicionamento do Empreendimento Social - Terra Nova

\begin{tabular}{|c|c|c|c|}
\hline Fotores & Lógica de Wercodo & $\begin{array}{l}\text { Terra Nova } \\
\text { (PR) }\end{array}$ & Lógica Socid \\
\hline Objefivo principal & Aproveitar uma oportunidade de mercado & 1 & Resolver um problema socioambiental \\
\hline Oferta & $\begin{array}{l}\text { Bens e serviços voltados para o consumo } \\
\text { da populaçāo }\end{array}$ & 1 & $\begin{array}{l}\text { Bens e serviços voltados para necessidades básicas e/ou } \\
\text { que conservem a biodiversidade }\end{array}$ \\
\hline Intencionalidade & $\begin{array}{l}\text { Geração de valor social é um componente } \\
\text { importante, porém não central }\end{array}$ & 1 & Geraçāo de valor social é o core business do negócio \\
\hline Escala & Fator relevante & 1 & Replicabilidade é mais relevante que a escalabilidade \\
\hline Clientes & $\begin{array}{l}\text { Os dientes pertencem a diversas dasses } \\
\text { sociais }\end{array}$ & 1 & $\begin{array}{l}\text { Predominantemente segmentos da população que estão em } \\
\text { situaçāo de maior vulnerabilidade }\end{array}$ \\
\hline Fornecedores & $\begin{array}{l}\text { Os critérios para escolha são preço e } \\
\text { qualidade }\end{array}$ & -1 & $\begin{array}{l}\text { Procura-se contratar segmentos da população que estão em } \\
\text { situação de maior vulnerabilidade }\end{array}$ \\
\hline Colaboradores & Não há nenhuma prioridade na contrataçāo & 1 & $\begin{array}{l}\text { Prioridade para segmentos da população que estão em situação } \\
\text { de maior vulnerabilidade }\end{array}$ \\
\hline Processo decisório & $\begin{array}{l}\text { Não há mecanismos institucionais para } \\
\text { participaçāo coletiva }\end{array}$ & 1 & $\begin{array}{l}\text { Há mecanismos institucionais para participação coletiva } \\
\text { das comunidades com as quais o empreendimento atua }\end{array}$ \\
\hline Distribuiç̣̄o de logo [ & Distribuição de dividendos. & 1 & Lucro é totalmente investido \\
\hline Valor Econômico & $\begin{array}{l}\text { Todos os recursos são provenientes } \\
\text { de vendas de produtose servicios }\end{array}$ & -1 & $\begin{array}{l}\text { Depende de doaçōes e colaboraçōes institucionais para } \\
\text { desenvolver sua atividade prinçpal }\end{array}$ \\
\hline Total & & 6 & \\
\hline
\end{tabular}


As inovações implementadas pela Terra Nova podem ser observadas nas quatro categorias: produto/serviço (regularização fundiária), mercado (propriedades privadas invadidas a preços negociados), processo (cobrança por agentes comunitários e negociação de financiamento com bancos) e organizacional (desenvolvimento de lideranças, articulação com governo, criação de um fundo comunitário). A abrangência da inovação é regional (já regularizou terras no $\mathrm{PR}, \mathrm{SP}, \mathrm{GO}$ ) e a profundidade da inovação é muito alta uma vez que pode promover o desenvolvimento local em regiões abandonadas e desprovidas de qualquer tipo de infraestrutura básica (energia, água, esgoto e asfalto), melhorando a qualidade de vida da comunidade e viabilizando a arrecadação de taxas e impostos. Dessa forma, considera-se como uma inovação com potencial para ser considerada disruptiva.

Em termos de geração de valor socioambiental, considera-se que os resultados diretos da Terra Nova são: acesso à moradia (capital físico) e diminuição de custos de transação. De forma indireta, deve-se destacar o aumento do capital social por meio da criação de uma rede de colaboração comunitária visando a obtenção de melhorias locais, bem como a elevação do sentimento de cidadania/autoestima pelo fato dos moradores passarem a ser reconhecidos e se reconhecerem como cidadãos e proprietários legais de suas moradias. Como destacado por uma moradora da Vila Governadora, área regularizada pela atuação da Terra Nova: "A vida estava tão difícil que não tínhamos mais nada a perder. Meu marido dormia debaixo de uma lona. À noite, os sapos pulavam em cima dele. Não havia luz nem água. Eu lavava nossas roupas em um tambor. Foi tanto sofrimento, mas agora nós podemos viver em paz. É horrível saber que você vive em uma área de ocupação irregular. Agora, o bairro está mais valorizado e eu não saio daqui por nada." 


\section{2- Região Sudeste}

\subsection{1 - Solar Ear (SP)}

A Solar Ear foi criada, em 2005, pelo empresário canadense Howard Weinstein em Botsuana para produzir e comercializar aparelhos auditivos que usam baterias recarregáveis por energia solar. A organização tem como objetivo popularizar o mercado de aparelhos auditivos em países em desenvolvimento, especialmente para população desassistida. Iniciou as atividades no Brasil em 2009, na cidade de São Paulo, em parceria com o Instituto Cefac, organização não governamental que promove assistência fonoaudiológica, ortodôntica e otorrinolaringológica. Obteve a aprovação pela Anvisa para funcionar no País em 2013. Desde 2012, seus produtos podem ser encontrados em 40 países.

Mais do que criar um produto com potencial de atender a grande maioria das pessoas com algum tipo de deficiência auditiva, Howard concebeu a Solar Ear como meio para inclusão social de deficientes. Assim, desde seu início, a organização capacita e emprega pessoas com deficiência auditiva, totalizando 40 pessoas diretamente empregadas em ambos os países e outras 35 alocadas em outras organizações.

Os aparelhos oferecidos pela Solar Ear custam de 400 a 1.200 reais - já incluindo as baterias recarregáveis e o carregador solar, representando $30 \%$ do preço de seus concorrentes. Além do preço mais acessível, o custo de manutenção do aparelho da Solar Ear é bastante inferior: suas baterias custam o equivalente a uma bateria comum, mas, por serem recarregáveis, chegam a durar até três anos - cerca de 100 vezes mais que seus concorrentes. Este era o grande desafio do empresário que constatou que "as pessoas de baixa renda na África, América Latina e Ásia usam os aparelhos auditivos até necessitarem trocar de bateria. Então, ou o colocam na gaveta ou o vendem, pois não têm recursos para comprar novas baterias" (Declaração de Howard à revista Newsweek, 2008).

O modelo de negócios da Solar Ear é baseado em uma oferta de valor adaptada a um público não atendido pela indústria de aparelhos auditivos por meio da venda de um produto de alta qualidade e baixos custos de aquisição (preço) e de manutenção. Esse diferencial de preços e qualidade é possível graças a cinco fatores:

1) Simplificação do produto com foco em suas funções mais importantes: um dos fatores que encarece os aparelhos auditivos é a inclusão de funções 
complementares, tais como resposta automática de telefone, botão de memória para configurações programáveis, entre outros. Cada uma dessas funções exige o desenvolvimento de um novo aparelho, com uma nova tecnologia, o que resulta em um produto mais sofisticado e caro para o consumidor final. Os aparelhos da Solar Ear são mais simples e sem essas funcionalidades adicionais.

2) Estratégia de marketing: As empresas líderes da indústria costumam ter elevados gastos com a divulgação e o marketing dos seus produtos. Essas empresas costumam patrocinar congressos e possuem uma estrutura de vendas bastante onerosa. Com disponibilidade de recursos muito limitada, a Solar Ear adota uma estratégia de marketing de baixo custo por meio da divulgação de seus produtos em clínicas populares e aparição espontânea na mídia.

3) Reinvestimento do Lucro: o objetivo da Solar Ear, ao contrário das empresas tradicionais do setor, não é de maximizar o lucro. O seu objetivo é social e de inserção da população com deficiência auditiva. Dessa maneira, o lucro proveniente das vendas dos produtos é visto como um meio para garantir a operação da empresa no longo prazo, sem ter a necessidade de doações. Todo o lucro obtido é reinvestido na empresa e na sua missão social. Isso permite que a organização trabalhe com margens menores, em comparação aos concorrentes e, consequentemente, ofereça produtos a preços mais baixos.

4) Desenvolvimento da tecnologia de carregadores solares: outro grande desafio solucionado pela Solar Ear foi a redução drástica do custo de operação dos aparelhos auditivos pela substituição de suas baterias. As baterias tradicionais têm duração de uma semana e custam cerca de $\mathrm{R} \$ 3,00$ - aproximadamente $\mathrm{R} \$ 150,00$ por ano. Por conta disto, muitos aparelhos doados acabam sendo inutilizados, pois seus portadores - em especial aqueles pertencentes às classes D e E - não possuem recursos de comprar novas baterias. A Solar Ear desenvolveu um carregador analógico que pode ser alimentado por energia solar ou eletricidade. A tecnologia de baterias recarregáveis foi adaptada para aparelhos auditivos, resultando em baterias com uma vida útil de até três anos e de preço similar ao das baterias tradicionais. Os carregadores solares permitem o uso dos aparelhos auditivos por pessoas que vivem em regiões desabastecidas de energia elétrica. A tecnologia utilizada pela Solar Ear 
não é patenteada e é oferecida gratuitamente, inclusive para potenciais concorrentes. De acordo com a gerente de operações no Brasil, Andrea Resende, a justificativa desta atitude está diretamente relacionada à missão social da empresa "não existe uma única empresa no mundo que consiga atender a toda a população que precisa de um aparelho auditivo. Nossa missão é democratizar o acesso à reabilitação auditiva e dar mais oportunidades de inclusão social para as pessoas com deficiências auditivas".

5) Inclusão de jovens com deficiência auditiva em suas linhas de montagem. Observouse que deficientes auditivos possuem excelente coordenação motora, o que os torna especialmente habilidosos para manusear e montar as delicadas peças que compõem os aparelhos auditivos e os carregadores solares. A Solar Ear realiza um trabalho de capacitação de jovens surdos em microeletrônica, gestão da qualidade e gestão de estoques.

Com suas inovações em produto e trabalho inclusivo, Howard e a Solar Ear receberam reconhecimento internacional. O empreendedor recebeu em 2009 o Tech Award do The Tech Museum of Innovation. A Solar Ear foi indicada pela revista Fast Company como uma das 10 empresas mais inovadoras do Brasil em 2011. Em 2012, recebeu o prêmio World Technology Network como melhor negócio social global. Além disso, os seus produtos são recomendados pela Organização Mundial da Saúde (OMS) e foram testados e aprovados por estudos das universidades de Michigan (EUA) e Copenhagen (Dinamarca).

Os dados levantados permitem classificar a Solar Ear como um empreendimento social com uma lógica de atuação com muita ênfase no social, obtendo uma pontuação de 6 (de um total que varia de -10 a 10$)$, vide na tabela 7 , a seguir. 
Tabela 7 - Posicionamento do Empreendimento Social - Solar Ear

\begin{tabular}{|c|c|c|c|}
\hline Fatores & Lógica de Wercodo & $\begin{array}{l}\text { Solar Ear } \\
\text { (SP) }\end{array}$ & Lógica Socid \\
\hline Objetivo principal & Aproveitar uma oportunidade de mercado & 1 & Resolver um problema socioambiental \\
\hline Oferta & $\begin{array}{l}\text { Bens e serviços voltados para o consumo } \\
\text { da população }\end{array}$ & 1 & $\begin{array}{l}\text { Bens e serviços voltados para necessidades básicas e/ou } \\
\text { que conservem a biodiversidade }\end{array}$ \\
\hline Infencionalidade & $\begin{array}{l}\text { Geração de valor social é um componente } \\
\text { importante, porém não central }\end{array}$ & 1 & Geração de valor social é o core business do negócio \\
\hline Escala & Fator relevante & 1 & Replicabilidade é mais relevante que a escalabilidade \\
\hline Clientes & $\begin{array}{l}\text { Os dientes pertencem a diversas dasses } \\
\text { sociais }\end{array}$ & 1 & $\begin{array}{l}\text { Predominantemente segmentos da população que estão em } \\
\text { situação de maior vulnerabilidade }\end{array}$ \\
\hline Fornecedores & $\begin{array}{l}\text { Os critérios para escolha são preço e } \\
\text { qualidade }\end{array}$ & 1 & $\begin{array}{l}\text { Procura-se contratar segmentos da população que estão em } \\
\text { situação de maior vulnerabilidade }\end{array}$ \\
\hline Colaboradores & Não há nenhuma prioridade na contratação & 1 & $\begin{array}{l}\text { Prioridade para segmentos da população que estão em situaçāo } \\
\text { de maior vulnerabilidade }\end{array}$ \\
\hline Processo decisório & $\begin{array}{l}\text { Não há mecanismos institucionais para } \\
\text { participação coletiva }\end{array}$ & -1 & $\begin{array}{l}\text { Há mecanismos institucionais para participação coletiva } \\
\text { das comunidades com as quais o empreendimento atua }\end{array}$ \\
\hline Distribsiç̣̄o de locro & Distribuição de dividendos. & 1 & Lucro é totalmente investido \\
\hline Valor Econômico & $\begin{array}{l}\text { Todos os recursos são provenientes } \\
\text { de vendas de produtos e servicicos }\end{array}$ & -1 & $\begin{array}{l}\text { Depende de doações e colaborações institucionais para } \\
\text { desenvolver sua atividade principal }\end{array}$ \\
\hline Tofal & & 6 & \\
\hline
\end{tabular}

Fonte: elaborada pela autora

As inovações implementadas pela Solar Ear podem ser observadas em quatro categorias: produto (baterias recarregáveis), mercado (canais diferenciados para venda), processo (tecnologia mais simples) e organizacional (inclusão de pessoas com deficiência no processo produtivo). A abrangência da inovação é global e a profundidade da inovação é alta uma vez que reconfigura o mercado de aparelhos auditivos por meio da oferta de uma tecnologia aberta (sem patentes), limpa (bateria recarregável com energia solar) e de baixo custo. Assim, considera-se uma inovação com potencial para ser disruptiva.

Em termos de geração de valor socioambiental, considera-se que os resultados diretos da Solar Ear são: capital físico, com a oferta de um bem que gera melhoria da saúde, contribuição para uma economia de baixo carbono (bateria recarregável com energia solar) e promoção da inclusão social de pessoas com deficiência, promoção de cidadania, por meio da capacitação de mão de obra. 


\subsection{2 - Policlínica Granato (RJ)}

A Policlínica Granato é uma clínica popular que oferece mais de 40 especialidades médicas e odontológicas, exames laboratoriais e exames de imagem à população de baixa renda a preços acessíveis. A Policlínica Granato surgiu para preencher a lacuna de atendimento de serviços de saúde existente entre a oferta insuficiente do Sistema Unificado de Saúde (SUS) e os estabelecimentos vinculados aos convênios e aos planos de seguro e de saúde particulares, deixando grande parte da população sem acesso aos serviços médicos de qualidade. Em 2014, a Policlínica contava com duas unidades de atendimento (São Conrado e Tijuca), na cidade do Rio de Janeiro, e funcionava como uma "parada única" da saúde. 0 paciente consegue realizar a consulta, o exame e o retorno na mesma hora e local. Essa agilidade no atendimento gera um ganho de tempo para um eventual tratamento e também no dia a dia da pessoa.

Para manter a qualidade do atendimento a preços acessíveis e conseguir ser financeiramente rentável, a Granato adotou uma estratégia de liderança em custos: organização com responsabilidades claramente atribuídas, incentivos baseados em produtividade e processos estruturados para um elevado volume de atendimento. O que lhe permite manter uma média de 5.000 consultas por mês. A Granato opera como uma plataforma que conecta médicos e pacientes.

Os dados levantados permitem classificar Policlínica Granato como exemplo de um empreendimento que tem sua lógica de atuação pautada com muita ênfase no mercado e que aproveita a ineficiência da atuação do Estado como uma oportunidade de mercado. Sua pontuação é de -6 (de um total que varia de -10 a 10), vide na tabela 8 , a seguir. 
Tabela 8 - Posicionamento do Empreendimento Social - Policlínica Granato

\begin{tabular}{|c|c|c|c|}
\hline Fotores & Lógica de Mercodo & $\begin{array}{c}\text { Policlinica } \\
\text { Granato } \\
\text { (RJ) }\end{array}$ & IogicaSodid \\
\hline Objetivo prindpol & Aproveitor uma oportunidode de mercodo & -1 & Resolver um problema socioombientol \\
\hline Oferto & $\begin{array}{l}\text { Bens e servicos voltodos para o consumo } \\
\text { do populaçón }\end{array}$ & 1 & $\begin{array}{l}\text { Bens e servicos voltados para necessidades bésicos a/ou } \\
\text { que conservem a biodiversidade }\end{array}$ \\
\hline Intendomalidode & $\begin{array}{l}\text { Geroçōo de valor social é um componente } \\
\text { importante, porém näo centrel }\end{array}$ & -1 & Geraçảo de volor social é o core business do negódio \\
\hline Escala & Fator relevante & -1 & Replicobilidade é mois relevante que o escalobilidade \\
\hline Clientes & $\begin{array}{l}\text { Os dientes pertencem a diversos dosses } \\
\text { sociois }\end{array}$ & 1 & $\begin{array}{l}\text { Predominantemente segmentos da populoçāo que estão em } \\
\text { situoçăo de maior vulnerabilidade }\end{array}$ \\
\hline Fornecedores & $\begin{array}{l}\text { Os aitérios paro escolha sōo preçe } \\
\text { qualidade }\end{array}$ & -1 & $\begin{array}{l}\text { Procuro-se controter segmentos da populoçāo que estōo em } \\
\text { situoçāo de maior vulnerabitidade }\end{array}$ \\
\hline Coloborodores & Nöo há nenhuma prioridade ne contrataçōo & -1 & $\begin{array}{l}\text { Prioridade poro segmentos da populoçōo que estỗo em situoçâo } \\
\text { de maior vulnerobilidade }\end{array}$ \\
\hline Processo dedsério & $\begin{array}{l}\text { Nöo há meconismos insfítudionais para } \\
\text { porticipoçâo coletiva }\end{array}$ & -1 & $\begin{array}{l}\text { Há meconismos insfitudionais para participoçâo colefiva } \\
\text { das comunidades com as quais o empreendimento atua }\end{array}$ \\
\hline Distribaiçäo de locao & Distribuiçōo de dividendos. & -1 & Luco é fotalmente investido \\
\hline Volor Econônico & $\begin{array}{l}\text { Todos os recursos sōo provenientes } \\
\text { de vendos de produlose servicos }\end{array}$ & -1 & $\begin{array}{l}\text { Depende de doacōes e colaboraçōes institucionais para } \\
\text { desenvolver suo atividade prinápal }\end{array}$ \\
\hline Toted & & -6 & \\
\hline
\end{tabular}

Fonte: elaborada pela autora

A inovação implementada pela Granato é tipicamente de processo, pois, para que consiga manter preços acessíveis, a gestão é direcionada para controle de custos. A abrangência da inovação é local, sendo a sua profundidade caracterizada como incremental.

Em termos de geração de valor socioambiental, pode-se dizer que o resultado gerado é melhoria do capital humano em função da prestação de uma ampla gama de serviços de saúde.

\subsection{3 - Gerasol (MG)}

A empresa Gerasol foi criada em Belo Horizonte, em 2012, a partir de um projeto de extensão da Universidade Federal de Minas Gerais (UFMG), desenvolvido em 2009. O empreendedor Rafael Xavier, geógrafo, vislumbrou a oportunidade de criar um empreendimento para disseminar uma tecnologia social - aquecedores solares de baixo custo (ASBC) - e capacitar profissionalmente pessoas provenientes do segmento de baixa renda da população para montagem e instalação de aquecedores solares.

Rafael conheceu a tecnologia de aquecimento solar por meio da Sociedade do Sol, instituição sem fins lucrativos incubada pelo Centro de Inovação, Empreendedorismo e Tecnologia (CIETEC), da Universidade de São Paulo (USP). O sistema de aquecedores solares 
de baixo custo (ASBC) é constituído de materiais simples - tubos de PVC, caixa d'água comum, forro de PVC e resina.

A receita da Gerasol advém principalmente de cursos de capacitação em ABSC, cujos principais clientes são pessoas interessadas em economizar e utilizar energia limpa em suas casas. Os cursos atraem também multiplicadores que querem aprender e levar a tecnologia para suas cidades e tornarem-se empreendedores. O empreendedor reserva $10 \%$ das vagas para população que não tem condições de pagar o curso.

Em seu início, a Gerasol oferecia somente cursos de capacitação. Após alguns meses de operação, Rafael percebeu que todos seus alunos tinham dificuldade de encontrar os insumos necessários para a construção do ASBC e passou, então, a também comercializar estes materiais. Para atender um segmento de mercado que gostaria de ter acesso ao ASBC, mas não tem o interesse de construí-lo, a Gerasol comercializa-os já prontos. Aliado a estas vendas, Rafael comercializa também serviços de assessoria e de instalação dos aquecedores. No entanto, este não é o foco da empresa, que tem um retorno financeiro muito maior com os cursos de capacitação do que com a venda do ASBC, uma vez que conta somente com a mão de obra de Rafael e uma secretária.

Eventualmente, a Gerasol recebe a demanda de grandes projetos de diversas instituições como creches, hospitais e escolas - exigindo a mão de obra de vários profissionais para sua construção. Rafael desenvolveu uma rede com alguns de seus ex-alunos para o desenvolvimento destes projetos que acontecem de forma pontual, conseguindo ter uma estrutura flexível e barata.

Os dados levantados permitem classificar a Gerasol como um empreendimento social com uma lógica de atuação equilibrada entre mercado e social, porém com mais viés no social. Obteve uma pontuação de 4 (de um total que varia de -10 a 10), vide na tabela 9 , a seguir. 
Tabela 9 - Posicionamento do Empreendimento Social - Gerasol

\begin{tabular}{|c|c|c|c|}
\hline Fateres & Legicade Mercodo & $\begin{array}{l}\text { Gerasol } \\
\text { (MG) }\end{array}$ & Logicosedid \\
\hline Objetivo principol & Aproveitar uma oportunidade de mercodo & 1 & Resolver um problema sooioombientel \\
\hline Oferta & $\begin{array}{l}\text { Bens e servicos volitodos paro o consumo } \\
\text { da populocốo }\end{array}$ & 1 & $\begin{array}{l}\text { Bens e servicos voltados pora necessidodes bósicas e/ou } \\
\text { que conservem a biodiversidade }\end{array}$ \\
\hline Intenciomolidade & $\begin{array}{l}\text { Geraçōo de valor social é um componente } \\
\text { importonte, porém nōo central }\end{array}$ & 1 & Geroccīo de volor sociol é o core business do negócio \\
\hline Escala & Fotor relevante & 1 & Replicabilidade é mais relevante que a escalobilidade \\
\hline Clientes & $\begin{array}{l}\text { Os dientes pertenceen a diversos dosses } \\
\text { sodiais }\end{array}$ & 1 & $\begin{array}{l}\text { Predominontemente segmentos da populociōo que estāo em } \\
\text { situoçōo de moior vulnerobilidode }\end{array}$ \\
\hline Fornecedores & $\begin{array}{l}\text { Os criterios para escotha sōo preco e } \\
\text { quolidode }\end{array}$ & 1 & 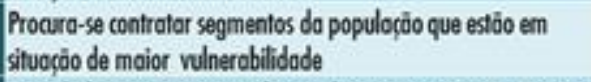 \\
\hline Colaberodores & Nōo há nenhuma prioridode na contratoçōo & 1 & $\begin{array}{l}\text { Prioridade para segmentos da populaç̄o que estōo en situacço } \\
\text { de maior vulnerabilidade }\end{array}$ \\
\hline Processo dedsório & $\begin{array}{l}\text { Nāo há meconismos institucionois paro } \\
\text { parfiópoçōo colefiva }\end{array}$ & -1 & $\begin{array}{l}\text { Há meconismos institucionais para participaç̄o colefiva } \\
\text { das comunidades com as quais o empreendimento atva }\end{array}$ \\
\hline Distribeiçōo de Iecro & Distribuiçóo de dividendos. & -1 & Luco é totalmente investido \\
\hline Valor Econōmico & $\begin{array}{l}\text { Todos os recursos sõo provenientes } \\
\text { de vendes de produtos e servicos }\end{array}$ & -1 & $\begin{array}{l}\text { Depende de doaçōes e colaboroçoes institucioneis para } \\
\text { desenvolver sua afividade principol }\end{array}$ \\
\hline Iotd & & 4. & \\
\hline
\end{tabular}

Fonte: elaborada pela autora

A principal inovação da Gerasol é mercadológica, pois identificou uma oportunidade de mercado na disseminação de uma tecnologia social de ASBC em MG. A abrangência da inovação é regional, especialmente na formação de multiplicadores, e a sua profundidade caracterizada como incremental.

Em termos de geração de valor socioambiental, considera-se que os resultados diretos são: contribuição para uma economia de baixo carbono a partir da disseminação de uma tecnologia limpa e formação de multiplicadores em montagem de ASBC (capital humano). Como resultado indireto, destaca-se a geração de renda pela contratação de alunos capacitados pela empresa (capital produtivo).

\subsection{4 - Treebos (ES)}

A Treebos foi fundada, em 2013, por Murilo Ferraz. Tem como objetivo ligar grupo de pequenos produtores rurais de baixa renda, que não tinha recursos para a colheita e muito menos para escoar sua produção, a seus clientes. É um negócio que une a agricultura ao mundo digital. "Sendo médico de família em Roraima, eu vi crianças comendo argila misturada na comida para matar a fome. Também ouvi de um produtor de arroz da região que toda sua produção era exportada para a Ásia. Isso me despertou para a questão da 
alimentação e fiquei pensando em como produzir alimentos de forma descentralizada e socialmente justa." Murilo Ferraz Fundador da Treebos.

Seguindo orientações do Instituto Capixaba de Pesquisa, Assistência Técnica e Extensão Rural (Incaper), a Treebos desenvolveu um modelo de pomar de 10 hectares - chamado de "bosque do futuro" - para pequenos agricultores rurais. Nessa área, são plantadas três dentre 35 espécies de frutas selecionadas pela organização. A Treebos contava, em 2014, com dois bosques: Guarapari (ES) e Campos dos Goytacazes (RJ).

Cada árvore dos bosques é colocada para "adoção" na internet e a pessoa que a adota passa a ter direito sobre as frutas produzidas. As frutas poderão ser entregues na casa do dono adotivo, em instituições de caridade, escolas e hospitais cadastrados ou vendidas na feira virtual da própria Treebos. A empresa cobra uma mensalidade para financiar o sistema. Além disso, seu faturamento é complementado por assinaturas de delivery de frutas (individuais e corporativas), venda ao varejo e comercialização de polpa de frutas congelada.

Os dados levantados permitem classificar a Treebos como um empreendimento social que estrutura sua atuação de forma bem equilibrada entre uma lógica de mercado e lógica social o que reflete em uma pontuação bem balanceada (-2) de um continuum que varia de 10 a 10. Vide tabela 10 abaixo.

Tabela 10 - Posicionamento do Empreendimento Social - Treebos

\begin{tabular}{|c|c|c|c|}
\hline Fotores & Lógica de Mercodo & $\begin{array}{l}\text { Treebos } \\
\text { (ES) }\end{array}$ & Lógica Socid \\
\hline Objefivo principal & Aproveitar uma oportunidade de mercado & 1 & Resolver um problema socioambiental \\
\hline Oferta & $\begin{array}{l}\text { Bens e serviços voltados para o consumo } \\
\text { da populaçấo }\end{array}$ & 1 & $\begin{array}{l}\text { Bens e servicos voltados para necessidades básicas e/ou } \\
\text { que conservem a biodiversidade }\end{array}$ \\
\hline Intencionalidade & $\begin{array}{l}\text { Geração de valor social é um componente } \\
\text { importante, porém não central }\end{array}$ & 1 & Geração de valor social é o core business do negócio \\
\hline Escala & Fator relevante & -1 & Replicabilidade é mais relevante que a escalabilidade \\
\hline Clientes & $\begin{array}{l}\text { Os clientes pertencem a diversas dasses } \\
\text { sociais }\end{array}$ & -1 & $\begin{array}{l}\text { Predominantemente segmentos da população que estão em } \\
\text { situaçāo de maior vulnerabilidade }\end{array}$ \\
\hline Fornecedores & $\begin{array}{l}\text { Os critérios para escolha são preço e } \\
\text { qualidade }\end{array}$ & 1 & $\begin{array}{l}\text { Procura-se contratar segmentos da população que estão em } \\
\text { situaçāo de maior vulnerabilidade }\end{array}$ \\
\hline Colaboradores & Não há nenhuma prioridade na contratação & -1 & $\begin{array}{l}\text { Prioridade para segmentos da população que estão em situação } \\
\text { de maior vulnerabilidade }\end{array}$ \\
\hline Processo decisório & $\begin{array}{l}\text { Não há mecanismos institucionais para } \\
\text { participação coletiva }\end{array}$ & -1 & $\begin{array}{l}\text { Há mecanismos institucionais para participacão coletiva } \\
\text { das comunidades com as quais o empreendimento atua }\end{array}$ \\
\hline Distribuiç̣̄o de loaro & Distribuição de dividendos. & -1 & Lucro é totalmente investido \\
\hline Valor Econômico & $\begin{array}{l}\text { Todos os recursos são provenientes } \\
\text { de vendas de produtose servictos }\end{array}$ & -1 & $\begin{array}{l}\text { Depende de doações e colaboraccões institucionais para } \\
\text { desenvolver sua atividade principal }\end{array}$ \\
\hline Total & & -2 & \\
\hline
\end{tabular}


As inovações implementadas pela Treebos são de produto, visto que criou um serviço inovador de adoção de árvore pela internet, e também de mercado, pelas diferentes formas de cobrança de serviços e canais de venda. A abrangência da inovação é local e a sua profundidade caracterizada como incremental, considerando que a inovação preenche uma lacuna de mercado, a saber: aproximação entre produtores locais e consumidores.

Em termos de geração de valor socioambiental, considera-se que os resultados diretos da Treebos são: aumento de renda (capital produtivo) e diminuição de custos de transação (eliminação de intermediários). Como benefícios indiretos, destaca-se a oferta de produtos orgânicos com impacto positivo na saúde das pessoas.

\section{3 - Região Centro-Oeste}

\subsection{1 - Ouro Verde (MT)}

A Ouro Verde é uma empresa, localizada em Alta Floresta, no estado de Mato Grosso, que comercializa produtos derivados da castanha do Brasil (também chamada de castanha do Pará). A empresa foi criada por Luis Fernando Laranja Fonseca, em 2002, então professor da Universidade de São Paulo (USP). Sua a proposta é aperfeiçoar a cadeia de produção e comercialização da castanha, contribuindo para elevar a geração de renda dos "castanheiros", eliminar a figura do "atravessador" e estabelecer melhores padrões de preços para a aquisição do fruto "in natura".

A empresa Ouro Verde foi concebida a partir de dois pilares de atuação: inovação em produto de maior valor agregado e relacionamento diferenciado com as comunidades fornecedoras. Com a experiência em pesquisa agroflorestal, Laranja estudou alternativas de produtos com maior valor agregado que poderiam ser obtidos com a castanha, criando o azeite de mesa, a farinha granulada e o creme de castanha.

A organização trabalha com o conceito de comércio justo junto a seus fornecedores e desenvolveu uma série de iniciativas de apoio e capacitação a essas comunidades. Tais iniciativas vão desde uma cartilha que ensina procedimentos de coleta orgânica, passando por apoio no transporte dos produtos, até a ajuda com a emissão de notas fiscais e antecipação de pagamento pela coleta. Tais ações têm impacto direto na renda e na 
qualidade de vida dos castanheiros e suas famílias, além do estimulo à preservação da Floresta Amazônica por meio de uma atividade econômica ambientalmente sustentável.

O primeiro desafio da Ouro Verde foi encontrar mercado para seus produtos inovadores. $\mathrm{O}$ azeite, o granulado e o creme são vendidos, principalmente, por lojas especializadas das regiões Sul e Sudeste do país. As grandes redes de supermercado e a indústria alimentícia compram majoritariamente a castanha in natura, correspondendo ainda por $90 \%$ do volume de vendas da empresa.

O segundo desafio está relacionado diretamente à dinâmica do mercado da castanha e à forma com a qual a Ouro Verde apoia a produção de seus fornecedores. Todos os fornecedores são pagos à vista e o fornecimento do ano todo tem que ser adquirido na época da safra, de dezembro a abril. No entanto, as vendas são diluídas ao longo do ano. Esse descasamento de pagamentos e recebimentos gera a necessidade de elevados volumes de capital de giro por parte da empresa. Em 2009, um novo sócio entrou no negócio com o intuito de solucionar estes desafios: o Grupo Jari - grupo empresarial com forte atuação no Norte do Brasil, em especial no setor de celulose - e que já se destacava na região por projetos de investimento social privado, principalmente de incentivo ao empreendedorismo e ao desenvolvimento local. Assim, a Ouro Verde é um dos poucos casos no Brasil27 de um negócio social que tem como sócio majoritário uma empresa "tradicional", ainda que tenha afinidade com os valores da responsabilidade social corporativa. A entrada do novo sócio trouxe o aporte de capital necessário para que a Ouro Verde desse um salto no seu patamar de operação. Desse aporte, cerca de $70 \%$ foi utilizado como capital de giro para expandir o negócio e o restante, em equipamentos e melhorias da estrutura física da fábrica. Além disso, a Jari também abriu novas portas de comercialização para os produtos da Ouro Verde. Com maior capital de giro e novas oportunidades de negócios, entre 2008 e 2010, a organização aumentou seu faturamento em mais de $700 \%$.

Os dados levantados permitem classificar a Ouro Verde como um empreendimento social com uma lógica de atuação com muita ênfase no mercado, obtendo uma pontuação de -6 (de um total que varia de -10 a 10 ), vide na tabela 11 a seguir. 
Tabela 11 - Posicionamento do Empreendimento Social - Ouro Verde

\begin{tabular}{|c|c|c|c|}
\hline Fotores & Lógica de Mercodo & $\begin{array}{l}\text { Ouro Verde } \\
\text { (MT) }\end{array}$ & Lógica Socid \\
\hline Objetivo prindipal & Aproveitar uma oportunidade de mercado & -1 & Resolver um problema socioambiental \\
\hline Oferta & $\begin{array}{l}\text { Bens e serviços voltados para o consumo } \\
\text { da população }\end{array}$ & -1 & $\begin{array}{l}\text { Bens e servicos voltados para necessidades básicas e/ou } \\
\text { que conservem a biodiversidade }\end{array}$ \\
\hline Intencionalidade & $\begin{array}{l}\text { Geraçāo de valor social é um componente } \\
\text { importante, porém não central }\end{array}$ & -1 & Geração de valor social é o core business do negócio \\
\hline Escala & Fator relevante & -1 & Replicabilidade é mais relevante que a escalabilidade \\
\hline Clientes & $\begin{array}{l}\text { Os clientes pertencem a diversas classes } \\
\text { sociais }\end{array}$ & -1 & $\begin{array}{l}\text { Predominantemente segmentos da populaçāo que estão em } \\
\text { situação de maior vulnerabilidade }\end{array}$ \\
\hline Fornecedores & $\begin{array}{l}\text { Os critérios para escolha são preço e } \\
\text { qualidade }\end{array}$ & 1 & $\begin{array}{l}\text { Procura-se contratar segmentos da população que estão em } \\
\text { situação de maior vulnerabilidade }\end{array}$ \\
\hline Colaboradores & Não há nenhuma prioridade na contrataçāo & -1 & $\begin{array}{l}\text { Prioridade para segmentos da população que estão em situação } \\
\text { de maior vulnerabilidade }\end{array}$ \\
\hline Processo decisório & $\begin{array}{l}\text { Não há mecanismos institucionais para } \\
\text { participação coletiva }\end{array}$ & 1 & $\begin{array}{l}\text { Há mecanismos institucionais para participação coletiva } \\
\text { das comunidades com as quais o empreendimento atua }\end{array}$ \\
\hline Distribuiç̣̄o de luaro & Distribuiçāo de dividendos. & -1 & Lucro é totalmente investido \\
\hline Valor Econômico & $\begin{array}{l}\text { Todos os recursos são provenientes } \\
\text { de vendas de produtose servictos }\end{array}$ & -1 & $\begin{array}{l}\text { Depende de doaçôes e colaboraccôes institucionais para } \\
\text { desenvolver sua atividade principal }\end{array}$ \\
\hline Tofal & & -6 & \\
\hline
\end{tabular}

Fonte: elaborada pela autora

As inovações implementadas pela Ouro Verde são: produto, por meio do desenvolvimento de produtos de alto valor agregado a base da castanha, bem como organizacional, levando em conta o relacionamento estabelecido com as comunidades. A abrangência da inovação é regional e a sua profundidade caracterizada como institucional pela reconfiguração do mercado de compra da matéria-prima e de venda dos produtos extrativistas a base de castanha.

Em termos de geração de valor socioambiental, considera-se que os resultados diretos da Ouro Verde são: aumento de renda (capital produtivo), diminuição de custos de transação (oferta de capital de giro aos produtores e eliminação do "atravessador" na cadeia de comercialização) e conservação da biodiversidade (capital natural). Como resultados indiretos, desenvolvimento de capital social pelo estímulo a organização de grupos comunitários originalmente dispersos, os quais passaram a interagir de forma colaborativa e adquiriram status a partir da profissionalização de suas atividades como coletadores de castanha (capital humano). 


\subsection{2 - Instituto de Permacultura e Ecovilas do Cerrado - IPEC (GO)}

O Instituto de Permacultura e Ecovilas do Cerrado foi fundado, em 1998, pelo casal André Soares e Lucy Legan na cidade de Pirenópolis, em Goiás, com a finalidade de disseminar os valores da permacultura por meio da capacitação e experimentação de soluções sustentáveis no cerrado. O casal desenvolveu a tecnologia Húmus Sapiens de sanitário seco. Consiste em misturar serragem aos dejetos humanos, que, depois de decompostos, são levados a um minhocário para produção de adubo. Com esta e outras técnicas desenvolvidas e implantadas, o Instituto cresceu e hoje desenvolve estratégias de habitação ecológica, saneamento responsável, energia renovável, segurança alimentar, cuidado com a água e processos de educação para a sustentabilidade.

A metodologia de agricultura sustentável foi desenvolvida, nos anos 1970, pelo então professor Bill Mollison, em parceria com o ecologista David Holmgren, após perceber que os sistemas naturais desapareciam gradativamente em função da expansão da urbanização e industrialização. $O$ estudo baseava-se numa policultura de árvores perenes, arbustos, fungos e tubérculos, integrando diferentes disciplinas, tais como biologia, zootecnia, agricultura e arquitetura. A ideia proposta culminou na criação do termo permacultura (permanente + agricultura) e na publicação do livro Permacultura Um. Hoje o termo é visto de forma mais abrangente, abordando a cultura da permanência na Terra, isto é, como atuar no design da casa, do sítio, da cidade, ou no planejamento do uso do solo, de modo a consumir de forma consciente os recursos naturais essenciais à sobrevivência humana. Dessa forma, devolve aos sistemas energia suficiente para que se mantenham vivos e saudáveis, gerando assim um balanço positivo.

O IPEC atua com duas formas jurídicas: associação (ONG Ecocentro IPEC), com o objetivo de desenvolver novas tecnologias e utilizá-las na solução de problemas socioambientais; e a empresa IPEC, que tem o intuito de divulgar essas tecnologias para que sejam utilizadas e replicadas em outras regiões do Brasil por meio da oferta de cursos, visitas e hospedagem no albergue. 
Todo o dinheiro arrecadado pelos cursos e visitações é usado para pagar os salários dos funcionários e é reinvestido em sua totalidade no Centro e no desenvolvimento de novas tecnologias. O Ecocentro conta, ainda, com fundos provenientes de editais públicos e de instituições financiadoras.

Os dados levantados permitem classificar o IPEC como um empreendimento social com uma lógica de atuação com muita ênfase no social, obtendo uma pontuação de 8 (de um total que varia de -10 a 10), vide na tabela 12 abaixo.

Tabela 12 - Posicionamento do Empreendimento Social - IPEC

\begin{tabular}{|c|c|c|c|}
\hline Fotores & Lógica de Mercodo & $\begin{array}{l}\text { IPEC } \\
\text { (GO) }\end{array}$ & Lógica Socid \\
\hline Objefivo prinaipal & Aproveitar uma oportunidade de mercado & 1 & Resolver um problema socioambiental \\
\hline Oferta & $\begin{array}{l}\text { Bens e servicos voltados para o consumo } \\
\text { da populaçāo }\end{array}$ & 1 & $\begin{array}{l}\text { Bens e serviços voltados para necessidades básicas e/ou } \\
\text { que conservem a biodiversidade }\end{array}$ \\
\hline Intencionalidade & $\begin{array}{l}\text { Geraçāo de valor social é um componente } \\
\text { importante, porém não central }\end{array}$ & 1 & Geração de valor social é o core business do negócio \\
\hline Escala & Fator relevante & 1 & Replicabilidade é mais relevante que a escalabilidade \\
\hline Clientes & $\begin{array}{l}\text { Os clientes pertencem a diversas classes } \\
\text { sociais }\end{array}$ & -1 & $\begin{array}{l}\text { Predominantemente segmentos da população que estão em } \\
\text { situação de maior vulnerabilidade }\end{array}$ \\
\hline Fornecedores & $\begin{array}{l}\text { Os critérios para escolha são preço e } \\
\text { qualidade }\end{array}$ & 1 & $\begin{array}{l}\text { Procura-se contratar segmentos da população que estão em } \\
\text { situação de maior vulnerabilidade }\end{array}$ \\
\hline Colaboradores & Não há nenhuma prioridade na contratação & 1 & $\begin{array}{l}\text { Prioridade para segmentos da população que estão em situação } \\
\text { de maior vulnerabilidade }\end{array}$ \\
\hline Processo decisório & $\begin{array}{l}\text { Não há mecanismos institucionais para } \\
\text { participação coletiva }\end{array}$ & 1 & $\begin{array}{l}\text { Há mecanismos institucionais para participaccão coletiva } \\
\text { das comunidades com as quais o empreendimento atua }\end{array}$ \\
\hline Distribuiç̣ōo de loro & Distribuição de dividendos. & 1 & Lucro é totalmente investido \\
\hline Valor Econômico & $\begin{array}{l}\text { Todos os recursos são provenientes } \\
\text { de vendas de produtose servictos }\end{array}$ & 1 & $\begin{array}{l}\text { Depende de doaçōes e colaboraçōes institucionais para } \\
\text { desenvolver sua atividade principal }\end{array}$ \\
\hline Total & & 8 & \\
\hline
\end{tabular}

Fonte: elaborada pela autora

As inovações desenvolvidas pelo IPEC são, basicamente, de produtos, visto que desenvolvem diversos produtos baseados nos princípios da permacultura, como o sanitário seco. A abrangência da inovação é local, pois, apesar da disseminação dos conceitos da permacultura, sua atuação está centrada no ecocentro em sua sede. A inovação desenvolvida tem um caráter institucional visto que reconfigura o mercado por meio da criação de diferentes alternativas de produtos sustentáveis por meio do reaproveitamento de materiais.

Em termos de geração de valor socioambiental, considera-se que as contribuições diretas do IPEC são: aumento da consciência ambiental pelo estímulo a mudanças de hábitos de consumo (cidadania); conservação da biodiversidade (capital natural) e reaproveitamento de 
materiais. De forma indireta, deve-se destacar a contribuição do IPEC para uma economia de baixo carbono por meio da proposição de tecnologias limpas que usam energia renovável.

\subsection{3 - Você Aprende Agora (MS)}

O empreendimento Você Aprende Agora foi criado por Felipe Dib, em 2011, com o objetivo de facilitar e universalizar o ensino do idioma inglês e torná-lo acessível a todas as pessoas já acostumadas com a internet. Todas as aulas podem ser acessadas gratuitamente e o aluno pode assisti-las quantas vezes quiser, no horário em que lhe for mais conveniente. Assim, rompe as barreiras do custo dos cursos presenciais e do tempo para dedicar-se ao estudo, as quais dificultam que a população de baixa renda tenha condições de realizar esse aprendizado. Além das aulas gratuitas, o estudante pode adquirir créditos para fazer exercícios de fixação, aprofundamento, ter um certificado de aprendizagem ou ter aulas particulares pelo Skype com Felipe.

O curso emprega uma metodologia que enfatiza o ensino das palavras, frases e expressões mais utilizadas na língua inglesa, tendo como base o corpus da língua inglesa compilado pela Universidade de Cambridge, do Reino Unido. O intuito é que o aluno aprenda de maneira rápida e eficiente aquilo que realmente será utilizado na vida real. São 612 vídeo-aulas do início ao final do curso. Cada aula possui em média três minutos e o método prevê dez minutos de dedicação a cada uma delas, pois a recomendação é que o aluno assista ao vídeo pelo menos três vezes: uma para entender, outra para escrever e a última para repetir em voz alta seu conteúdo.

Os alunos estão espalhados por 181 países, com maior número de acessos provenientes do Brasil, Estados Unidos, Portugal, Irlanda e Japão.

O Você Aprende Agora é estruturado em uma lógica de modelo de negócios "freemium". O termo vem da junção das palavras "free" ("gratuito") e "premium" e é usado para designar um negócio em que o produto principal é oferecido de maneira gratuita e funcionalidades adicionais ou uma versão premium do produto é paga.

Por seu trabalho frente ao Você Aprende Agora, Felipe recebeu diversos prêmios: Prêmio Jovens Inspiradores - Voto Popular 2012; Prêmio Tech Ativismo Global Entrepreneurship 
Congress 2013 (Tech for Good); Prêmio Mérito Empreendedor MS 2013; Selecionado Visão de Sucesso - BID e Endeavor 2013.

Os dados levantados permitem classificar o Você Aprende Agora como um empreendimento com uma lógica clara de mercado, obtendo uma pontuação -6 (de um total que varia de -10 a 10), vide na tabela 13 , a seguir.

Tabela 13 - Posicionamento do Empreendimento Social - Você Aprende Agora

\begin{tabular}{|c|c|c|c|}
\hline Fatores & Lógica de Wiercado & $\begin{array}{l}\text { Você Aprende } \\
\text { Agora } \\
\text { (MS) }\end{array}$ & Lógica Socid \\
\hline Objefivo prinaipal & Aproveitar uma oportunidade de mercado & -1 & Resolver um problema socioambiental \\
\hline Oferta & $\begin{array}{l}\text { Bens e serviços voltados para o consumo } \\
\text { da populacão }\end{array}$ & 1 & $\begin{array}{l}\text { Bens e serviços voltados para necessidades básicas e/ou } \\
\text { que conservem a biodiversidade }\end{array}$ \\
\hline Intencionalidade & $\begin{array}{l}\text { Geração de valor social é um componente } \\
\text { importante, porém não central }\end{array}$ & -1 & Geraçāo de valor social é o core business do negócio \\
\hline Escala & Fator relevante & -1 & Replicabilidade é mais relevante que a escalabilidade \\
\hline Clientes & $\begin{array}{l}\text { Os dientes pertencem a diversas dasses } \\
\text { sociais }\end{array}$ & 1 & $\begin{array}{l}\text { Predominantemente segmentos da população que estão em } \\
\text { situação de maior vulnerabilidade }\end{array}$ \\
\hline Fornecedores & $\begin{array}{l}\text { Os critérios para escolha são preço e } \\
\text { qualidade }\end{array}$ & -1 & $\begin{array}{l}\text { Procura-se contratar segmentos da população que estão em } \\
\text { situação de maior vulnerabilidade }\end{array}$ \\
\hline Colaboradores & Não há nenhuma prioridade na contratação & -1 & $\begin{array}{l}\text { Prioridade para segmentos da população que estão em situação } \\
\text { de maior vulnerabilidade }\end{array}$ \\
\hline Processo decisório & $\begin{array}{l}\text { Não há mecanismos institucionais para } \\
\text { participaçāo coletiva }\end{array}$ & -1 & $\begin{array}{l}\text { Há mecanismos institucionais para partiaipação coletiva } \\
\text { das comunidades com as quais o empreendimento atua }\end{array}$ \\
\hline Distribsiĉ̣o de locro & Distribuição de dividendos. & -1 & Lucro é totalmente investido \\
\hline Valor Econômico & $\begin{array}{l}\text { Todos os recursos são provenientes } \\
\text { de vendas de produtose servicos }\end{array}$ & -1 & $\begin{array}{l}\text { Depende de doaçôes e colaboraçôes institucionais para } \\
\text { desenvolver sua atividade principal }\end{array}$ \\
\hline Tofal & & -6 & \\
\hline
\end{tabular}

Fonte: elaborada pela autora

A principal inovação do empreendimento é mercadológica, pois disponibilizou aulas de inglês de forma gratuita pela internet por meio de um modelo de negócios "freemium". A abrangência da inovação é global e a sua profundidade caracterizada como institucional ao possibilitar a reconfiguração da oferta de idiomas, tornando acessível a quem não tem tempo, recursos ou local próximo.

Em termos de geração de valor socioambiental, considera-se que o resultado direto do empreendimento é o aumento do capital humano pela possibilidade de aprender um novo idioma. Como resultado indireto, destaca-se o aumento do capital social pelo acesso à informação e inserção em novas redes de relacionamento. 


\subsection{4 - BIOON (DF)}

A Bioon é considerada o primeiro Ecomercado brasileiro: um mercado que oferta, especificamente, produtos orgânicos, naturais e sustentáveis. Sua proposta foi reformulada, em 2010, pelos irmãos Edson e Davi Neves com o propósito de oferecer ao cliente tudo aquilo de que precisa em termos de produtos sustentáveis, como alimentos orgânicos, suplementos alimentares, alimentos para pessoas com restrições alimentares, fraldas biodegradáveis, cosméticos de base natural. O café oferecido na loja não tem preço e o cliente paga o quanto "achar justo".

A Bioon busca conectar demanda e produção por meio de quatro diferentes canais de comercialização: loja física, site, ecomercado coletivo e consórcio. O ecomercado coletivo reúne clientes interessados em adquirir mensalmente uma "cesta básica natural". Essa iniciativa mostrou-se benéfica tanto para o pequeno produtor orgânico, que obtém maior volume e constância de vendas, quanto para o consumidor, que, por meio da compra coletiva, obtém preços até $15 \%$ menores aos de prateleira. O consórcio ${ }^{10}$ tem como objetivo financiar e apoiar tecnicamente a cultura de alimentos orgânicos de pequenos agricultores, compartilhando a decisão sobre o que vai ser plantado e os riscos do plantio.

Os dados levantados permitem classificar a Bioon como um empreendimento com uma lógica clara de mercado, obtendo uma pontuação -8 (de um total que varia de -10 a 10), vide na tabela 14 , a seguir.

\footnotetext{
${ }^{10}$ Esta modalidade estava em fase piloto na época da visita do empreendimento em 2013.
} 
Tabela 14 - Posicionamento do Empreendimento Social - BIOON

\begin{tabular}{|c|c|c|c|}
\hline Fatores & Lógica de Mercodo & $\begin{array}{l}\text { Bioon } \\
\text { (DF) }\end{array}$ & Lógica Socid \\
\hline Objetivo principal & Aproveitar uma oportunidade de mercado & -1 & Resolver um problema socioambiental \\
\hline Oferta & $\begin{array}{l}\text { Bens e serviços voltados para o consumo } \\
\text { da populaçấo }\end{array}$ & -1 & $\begin{array}{l}\text { Bens e servicos voltados para necessidades básicas e/ou } \\
\text { que conservem a biodiversidade }\end{array}$ \\
\hline Intencionalidade & $\begin{array}{l}\text { Geraçāo de valor social é um componente } \\
\text { importante, porém nõo central }\end{array}$ & -1 & Geração de valor social é o core business do negócio \\
\hline Escala & Fator relevante & -1 & Replicabilidade é mais relevante que a escalabilidade \\
\hline Clientes & $\begin{array}{l}\text { Os dientes pertencem a diversas dasses } \\
\text { sociais }\end{array}$ & -1 & $\begin{array}{l}\text { Predominantemente segmentos da populaçāo que estão em } \\
\text { situaçāo de maior vulnerabilidade }\end{array}$ \\
\hline Fornecedores & $\begin{array}{l}\text { Os critérios para escolha são preço e } \\
\text { qualidade }\end{array}$ & 1 & $\begin{array}{l}\text { Procura-se contratar segmentos da população que estão em } \\
\text { situação de maior vulnerabilidade }\end{array}$ \\
\hline Colaboradores & Não há nenhuma prioridade na contrataçāo & -1 & $\begin{array}{l}\text { Prioridade para segmentos da população que estão em situação } \\
\text { de maior vulnerabilidade }\end{array}$ \\
\hline Processo decisório & $\begin{array}{l}\text { Não há mecanismos institucionais para } \\
\text { participação coletiva }\end{array}$ & -1 & $\begin{array}{l}\text { Há mecanismos institucionais para participação coletiva } \\
\text { das comunidades com as quais o empreendimento atua }\end{array}$ \\
\hline Distribsic̣äo de locro & Distribuiçāo de dividendos. & -1 & Lucro é totalmente investido \\
\hline Valor Econômico & $\begin{array}{l}\text { Todos os recursos são provenientes } \\
\text { de vendas de produtos e servicicos }\end{array}$ & -1 & $\begin{array}{l}\text { Depende de doaçōes e colaboraçōes institucionais para } \\
\text { desenvolver sua atividade principal }\end{array}$ \\
\hline Totel & & -8 & \\
\hline
\end{tabular}

elaborada pela autora

A inovação observada na BIOON é mercadológica, visto que gerou acessibilidade de produtos mais saudáveis, ou próprios para dietas restritivas, no Distrito Federal e ofereceu diferentes canais de venda para produtores locais de produtos orgânicos. A abrangência da inovação é local e a sua profundidade incremental.

Em termos de geração de valor socioambiental, considera-se que o resultado direto da BIONN é a oferta de uma alimentação saudável (capital humano). De forma indireta, diminuem custos de transação pela oferta do financiamento a produtores locais na sua modalidade do consórcio e estimula maior consciência ambiental dos consumidores.

\section{4 - Região Nordeste}

\subsection{1 - Instituto de Co-Responsabilidade - Incores (BA)}

Instituto de Co-Responsabilidade Social, INCORES, como é mais conhecido, atua na gestão completa de programas de jovens aprendizes, o que inclui cursos de capacitação profissional, acompanhamento dos jovens por todo o período de contrato (dois anos) e a gestão da folha de pagamento dos aprendizes.

O INCORES surgiu, em 2010, como spin off do Programa Enter Jovem (PEJ) da American Institute for Research (AIR). Foi desenvolvido um material didático próprio, inspirado na metodologia de Paulo Freire e Reuven Feuerstein, ao fazer uso das experiências de vida de 
cada pessoa para se chegar ao aprendizado. O material exclusivo tem uma linguagem jovem, positiva e adaptada à realidade social dos alunos, para facilitar o aprendizado e reforçar a autoestima dos aprendizes. Outro diferencial é o apoio dado aos jovens (mentoring e coaching) para superar as naturais dificuldades pessoais e de relacionamento encontradas no ambiente de trabalho.

Segundo Tanya Andrade, fundadora do INCORES, a maioria dos clientes que recorre ao INCORES o faz, na primeira vez, para cumprir a legislação. Segundo o artigo 429 da Consolidação das Leis de Trabalho (CLT), qualquer organização - seja ela pública ou privada que tenha sete ou mais colaboradores, é obrigada a contratar jovens aprendizes, de acordo com um percentual exigido por lei. "Sem a lei do Jovem Aprendiz, nosso desafio para encontrar clientes seria ainda maior do que já é. A visão do impacto social que um programa de jovem aprendiz pode ter ainda não é o 'driver' que permeia a tomada de decisão da maior parte das empresas."

A organização é financeiramente sustentável. Sua renda é proveniente de uma taxa mensal por jovem treinado cobrada da empresa contratante. Esta taxa varia de acordo com o pacote de serviços contratado (seleção, acompanhamento e capacitação).

Como a capacitação destes jovens é uma atividade-chave da associação, a sala de aula é um recurso essencial, porém oneroso. Diversas parcerias foram firmadas no intuito de buscar estes recursos gratuitamente com universidades, escolas públicas e igrejas. Outra parceria muito importante foi estabelecida com a aceleradora social NESsT, que os auxiliou desde a análise do mercado até a estruturação do modelo de negócios.

Os dados levantados permitem classificar a INCORES como um empreendimento social que estrutura sua atuação de forma bem equilibrada entre uma lógica de mercado e lógica social o que reflete em uma pontuação bem balanceada $(-2)$ de um continuum que varia de 10 a 10. Vide tabela 15 abaixo. 
Tabela 15 - Posicionamento do Empreendimento Social - INCORES

\begin{tabular}{|c|c|c|c|}
\hline Fotores & Lógico de Merondo & $\begin{array}{l}\text { Incores } \\
\text { (BA) }\end{array}$ & Lógica Sodid \\
\hline Objetivo principal & Aproveitar uma oportunidade de mercado & -1 & Resolver um problema socioambiental \\
\hline Intencionalidade & $\begin{array}{l}\text { Geração de valor social é um componente } \\
\text { importante, porém não central }\end{array}$ & 1 & Geração de valor social é o core business do negócio \\
\hline Clientes & $\begin{array}{l}\text { Os dientes pertencem a diversas dasses } \\
\text { sociais }\end{array}$ & -1 & $\begin{array}{l}\text { Predominantemente segmentos da população que estão em } \\
\text { situação de maior vulnerabilidade }\end{array}$ \\
\hline Fornecedores & $\begin{array}{l}\text { Os critérios para escolha são preço e } \\
\text { qualidade }\end{array}$ & -1 & $\begin{array}{l}\text { Procura-se contratar segmentos da população que estão em } \\
\text { situação de maior vulnerabilidade }\end{array}$ \\
\hline Colaboradores & Não há nenhuma prioridade na contratação & 1 & $\begin{array}{l}\text { Prioridade para segmentos da população que estão em situação } \\
\text { de maior vulnerabilidade }\end{array}$ \\
\hline Distribuiçōo de loro & Distribuição de dividendos. & 1 & Lucro é totalmente investido \\
\hline Valor Econômico & $\begin{array}{l}\text { Todos os recursos são provenientes } \\
\text { de vendas de produtos e serviços }\end{array}$ & -1 & $\begin{array}{l}\text { Depende de doações e colaborações institucionais para } \\
\text { desenvolver sua atividade principal }\end{array}$ \\
\hline Total & & -2 & \\
\hline
\end{tabular}

Fonte: elaborada pela autora

As inovações implementadas pelo INCORES são de produto/serviços pelo desenvolvimento de metodologia própria e oferecimento de serviços de mentoring para jovens de baixa renda. Além disso, inovou na dimensão organizacional por meio do estabelecimento de parcerias para realização dos treinamentos sem custo de infraestrutura. A abrangência da inovação é local e a sua profundidade caracterizada como incremental.

Em termos de geração de valor socioambiental, considera-se que os principais resultados diretos oferecidos pelo INCORES são a profissionalização de jovens carentes (capital humano) e o aumento do capital social destes, que passam a participar de redes de empresas. Como resultado indireto, destaca-se a maior possibilidade de obtenção de emprego e, consequentemente, o incremento da geração de renda (capital produtivo).

\subsection{2 - Namastê (SE)}

A Namastê é uma produtora de chás e especiarias orgânicas, localizada no município de Nossa Senhora do Socorro, em Sergipe, a 20 km de Aracaju. Foi criada em 2001, após uma mudança de carreira da empreendedora Débora Silva, então sócia de uma empresa de tecnologia da informação. Com seus estudos práticos sobre plantações biodinâmicas, decidiu abrir um empreendimento que viabilizasse a produção de ervas para trazer benefícios para a 
saúde e, ao mesmo tempo, contribuir para a geração de renda de pequenos agricultores locais.

Desde a sua criação, a Namastê passou por três modelos de negócio. Na primeira fase da empresa (de 2001 a 2007), o empreendimento funcionou como um grande laboratório de plantação de ervas medicinais. Na propriedade de 50 hectares à beira do Rio São Francisco, onde a empresa operava, diversas experiências foram realizadas com o objetivo de descobrir quais plantas melhor se adaptariam à região. Mais de 50 espécies foram testadas em parceria com a Universidade Federal de Sergipe (UFS).

Apesar de ser proprietária da fazenda, a empreendedora tinha dificuldades para remunerar a mão de obra necessária para a plantação. A solução encontrada foi permitir que pequenos agricultores locais plantassem em sua propriedade para, posteriormente, comprar esta produção. Além de oferecer a terra, a empresa oferecia também ferramentas para o plantio e a capacitação necessária para que os agricultores trabalhassem de acordo com a filosofia da agricultura biodinâmica.

Após o período inicial, a Namastê começou a buscar o aumento de sua escala de produção. Neste momento, decidiu iniciar a produção de chá próprio. Surgiu, assim, a marca Namastê. Nesta segunda fase, o grande desafio da empresa tornou-se a venda do produto final: o chá. O produto da Namastê chegava às gôndolas a preços mais elevados que o dos concorrentes, por uma escolha do varejista, que percebia a disposição do nicho de consumidores de produtos saudáveis em pagar um preço mais alto em troca de saúde e bem-estar. Dessa maneira, o supermercado acaba trabalhando com uma margem de lucro muito maior para os produtos orgânicos em geral, o que dificulta sua venda. Adicionalmente, por ser a Namastê menor que seus concorrentes, ela tinha uma posição menos privilegiada nas gôndolas dos grandes mercados.

Como o volume de produção era muito pequeno para justificar a compra de maquinário de envase, este serviço era feito por um terceiro em São Paulo: as ervas para os chás eram enviadas a esta empresa que as envasava, embalava e enviava os produtos resultantes de volta para Sergipe. Só então os produtos eram vendidos e entregues a clientes de todo o Brasil. Logo, a logística passou a representar um enorme custo para a empresa. As dificuldades de comercialização do produto agravaram seu problema de capital de giro e Débora viu-se obrigada a buscar empréstimos para continuar comprando a produção dos 
agricultores e outros insumos, o que gerou um endividamento crônico e obrigou a empreendedora a reduzir seus custos para continuar sua operação.

A melhor maneira encontrada foi reduzir o quadro de funcionários, colocar a fazenda à venda e comprar as ervas em vez de produzi-las em sua própria terra junto aos agricultores. As ervas são compradas de cooperativas de Santa Catarina e do Rio Grande do Norte, processadas, envasadas e embaladas na Namastê e vendidas para grandes varejistas e lojas especializadas.

Os dados levantados permitem classificar a Namastê como um empreendimento com uma lógica clara de mercado, obtendo uma pontuação de -8 (de um total que varia de -10 a 10), vide na tabela 16 abaixo.

Tabela 16 - Posicionamento do Empreendimento Social - Namastê

\begin{tabular}{|c|c|c|c|}
\hline Fatores & Lógica de Mercodo & $\begin{array}{l}\text { Namastê } \\
\text { (SE) }\end{array}$ & Lógica Socid \\
\hline Objetivo principal & Aproveitar uma oportunidade de mercado & -1 & Resolver um problema socioambiental \\
\hline Oferta & $\begin{array}{l}\text { Bens e serviços voltados para o consumo } \\
\text { da populaçấo }\end{array}$ & -1 & $\begin{array}{l}\text { Bens e serviços voltados para necessidades básicas e/ou } \\
\text { que conservem a biodiversidade }\end{array}$ \\
\hline Intencionalidade & $\begin{array}{l}\text { Geraçāo de valor social é um componente } \\
\text { importante, porém não central }\end{array}$ & -1 & Geração de valor social é o core business do negócio \\
\hline Escala & Fator relevante & -1 & Replicabilidade é mais relevante que a escalabilidade \\
\hline Clientes & $\begin{array}{l}\text { Os dientes pertencem a diversas dasses } \\
\text { sociais }\end{array}$ & -1 & $\begin{array}{l}\text { Predominantemente segmentos da população que estão em } \\
\text { situação de maior vulnerabilidade }\end{array}$ \\
\hline Fornecedores & $\begin{array}{l}\text { Os critérios para escolha são preço e } \\
\text { qualidade }\end{array}$ & 1 & $\begin{array}{l}\text { Procura-se contratar segmentos da população que estão em } \\
\text { situação de maior vulnerabilidade }\end{array}$ \\
\hline Colaboradores & Não há nenhuma prioridade na contratação & -1 & $\begin{array}{l}\text { Prioridade para segmentos da população que estão em situaçāo } \\
\text { de maior vulnerabilidade }\end{array}$ \\
\hline Processo decisório & $\begin{array}{l}\text { Não há mecanismos institucionais para } \\
\text { participaçāo coletiva }\end{array}$ & -1 & $\begin{array}{l}\text { Há mecanismos institucionais para partiajpacão coletiva } \\
\text { das comunidades com as quais o empreendimento atua }\end{array}$ \\
\hline Distribuiçäo de loro & Distribuiçāo de dividendos. & -1 & Lucro é totalmente investido \\
\hline Valor Econômico & $\begin{array}{l}\text { Todos os recursos são provenientes } \\
\text { de vendas de produtose serviços }\end{array}$ & -1 & $\begin{array}{l}\text { Depende de doações e colaborações institucionais para } \\
\text { desenvolver sua atividade principal }\end{array}$ \\
\hline Tofal & & -8 & \\
\hline
\end{tabular}

Fonte: elaborada pela autora

A inovação observada na Namastê, de produto, aconteceu logo na primeira fase de seu modelo de negócios quando desenvolveu ervas específicas para região com princípios da biodinâmica e cedia suas terras para a plantação de pequenos. A abrangência da inovação é local sendo a sua profundidade caracterizada como incremental.

Em termos de geração de valor socioambiental, considera-se que o resultado direto da Namastê é a oferta de um produto saudável (capital humano). Somente na primeira e segunda fase de sua atuação, gerou renda na região para agricultores locais e aumento do capital humano pela capacitação em agricultura biodinâmica. Estes dois resultados foram 
interrompidos na terceira fase da empresa, levando em conta que toda a produção é comprada de outras localidades.

\subsection{3 - Associação de Amigos e Pais de Pessoas Especiais - AAPPE (AL)}

A AAPPE é uma associação que objetiva apoiar pessoas com deficiências auditivas/surdez no estado de Alagoas em todas as suas necessidades. Fundada em 1987, a AAPPE redirecionou seu foco de atuação em 1993 sob a liderança da analista de sistemas Iraê Cardoso, tornandose um centro de referência em surdez na região Nordeste. A instituição atua em cinco frentes principais:

- Educação complementar para surdos em várias faixas etárias;

- Ensino da Língua Brasileira de Sinais - Libras;

- Formação/capacitação de profissionais surdos e ouvintes para atuação na área da surdez;

- Atendimento clínico nas áreas de pediatria, clínica geral, otorrinolaringologia, neuropediatria, terapia ocupacional, fonoaudiologia, psicologia e estimulação precoce;

- Proteção e defesa de direitos da comunidade surda.

Suas receitas advêm, majoritariamente, cerca de 90\%, da prestação de serviços por meio do Sistema Único de Saúde (SUS). O restante provém da cobrança por serviços de educação e inserção profissional e de doações.

Com uma gestão financeira rigorosa, a AAPPE oferece serviços de saúde com uma qualidade bastante superior ao da média nacional: um atendimento ágil, gratuito, com profissionais gabaritados, equipamentos de ponta e estrutura adequada.

Os dados levantados permitem classificar o AAPPE como exemplo de um empreendimento social que tem sua lógica de atuação pautada com total ênfase no social, obtendo a pontuação máxima de 10, vide na tabela 17 a seguir. 
Tabela 17 - Posicionamento do Empreendimento Social - AAPPE

\begin{tabular}{|c|c|c|c|}
\hline Fatores & Lógica de Mercodo & $\begin{array}{l}\text { AAPPE } \\
\text { (AL) }\end{array}$ & Lógica Socid \\
\hline Objefivo prinaipal & Aproveitar uma oportunidade de mercado & 1 & Resolver um problema socioambiental \\
\hline Oferta & $\begin{array}{l}\text { Bens e servicos voltados para o consumo } \\
\text { da população }\end{array}$ & 1 & $\begin{array}{l}\text { Bens e serviços voltados para necessidades básicas e/ou } \\
\text { que conservem a biodiversidade }\end{array}$ \\
\hline Intencionalidade & $\begin{array}{l}\text { Geração de valor social é um componente } \\
\text { importante, porém nõo central }\end{array}$ & 1 & Geração de valor social é o core business do negócio \\
\hline Escala & Fator relevante & 1 & Replicabilidade é mais relevante que a escalabilidade \\
\hline Clientes & $\begin{array}{l}\text { Os dientes pertencem a diversas classes } \\
\text { sociais }\end{array}$ & 1 & $\begin{array}{l}\text { Predominantemente segmentos da populaçāo que estão em } \\
\text { situação de maior vulnerabilidade }\end{array}$ \\
\hline Fornecedores & $\begin{array}{l}\text { Os critérios para escolha são preço e } \\
\text { qualidade }\end{array}$ & 1 & $\begin{array}{l}\text { Procura-se contratar segmentos da população que estão em } \\
\text { situação de maior vulnerabilidade }\end{array}$ \\
\hline Colaboradores & Não há nenhuma prioridade na contrataçāo & 1 & $\begin{array}{l}\text { Prioridade para segmentos da população que estão em situação } \\
\text { de maior vulnerabilidade }\end{array}$ \\
\hline Processo decisório & $\begin{array}{l}\text { Não há mecanismos institucionais para } \\
\text { participação coletiva }\end{array}$ & 1 & $\begin{array}{l}\text { Há mecanismos institucionais para participação coletiva } \\
\text { das comunidades com as quais o empreendimento atua }\end{array}$ \\
\hline Distribuiç̣öo de luao & Distribuiçāo de dividendos. & 1 & Lucro é totalmente investido \\
\hline Valor Econômico & $\begin{array}{l}\text { Todos os recursos são provenientes } \\
\text { de vendas de produtose servictos }\end{array}$ & 1 & $\begin{array}{l}\text { Depende de doaçôes e colaboraccôes institucionais para } \\
\text { desenvolver sua atividade principal }\end{array}$ \\
\hline Tofal & & 10 & \\
\hline
\end{tabular}

Fonte: elaborada pela autora

A inovação implementada pela AAPPE é tipicamente de serviço pelo conjunto de ações voltadas à habilitação e à reabilitação integral da pessoa com deficiência auditiva e/ou múltiplas deficiências. A abrangência da inovação é local e a sua profundidade caracterizada como institucional porque tornou-se referência no atendimento integral de surdos.

Em termos de geração de valor socioambiental, pode-se dizer que a maior contribuição da AAPPE é melhoria do capital humano devido ao atendimento de saúde e oferta de cursos e aumento da autoestima de pessoas com deficiência auditiva. Em termos indiretos, contribui para a inserção dessas pessoas no mercado de trabalho (capital produtivo) e possibilita aumento do capital social de todos envolvidos (família e deficientes).

\subsection{4 - Bio Fair Trade (PE)}

A Bio Fair Trade foi criada, em 2007, com o objetivo de apoiar o pequeno produtor brasileiro no acesso ao mercado nacional e internacional, a partir dos princípios e valores do Comércio Justo. No entanto, a origem do empreendimento data de 2001, quando Fabiana Dumont, formada em administração com especialização em comércio exterior, foi trabalhar em um projeto de comércio justo da ONG Visão Mundial. Nesta ocasião, conheceu Márcio Waked, professor, empresário das áreas de TI e saúde, mestre em gestão do desenvolvimento local sustentável e com uma trajetória de mais de 10 anos de voluntariado. Em 2007, o projeto 
em que Fabiana atuava na Visão Mundial foi redimensionado e, juntos, Fabiana e Márcio vislumbraram a oportunidade de abrir um empreendimento social que pudesse dar continuidade ao trabalho iniciado. "A ideia era melhorar as condições para que os artesãos tivessem uma atividade perene e que os permitisse dali tirar o seu sustento, crescer $e$ se desenvolver" (Márcio Waked). Nasce então a Bio Fair Trade.

O diferencial da organização é o fornecimento de treinamentos, assessoria de design para criação de novos produtos conforme as tendências do mercado, consultorias para logística, exportação e até comercialização dos produtos. Além disso, há um trabalho cuidadoso na gestão da qualidade e pontualidade da entrega dos artesanatos, elevando o nível do serviço para um patamar raramente encontrado neste mercado.

A Bio Fair Trade comercializa somente para grandes varejistas, não para consumidores finais, funcionando como um elo de comunicação entre as redes e os artesãos. Os compradores pesquisam as tendências de mercado e fornecem essas informações ou, até mesmo, o design final dos produtos para a Bio Fair Trade. Esta, por sua vez, auxilia no desenvolvimento de novos produtos, quando necessário, e busca os grupos de artesãos com as habilidades específicas para a produção solicitada. Dessa maneira, os artesãos iniciam a produção sob demanda, já com a certeza da compra, contrariando a lógica convencional em que os produtos são produzidos para estoque e apenas posteriormente busca-se a comercialização.

Além de ter uma missão social bem clara de melhorar a vida dos artesãos por meio do aumento de suas rendas, a busca da Bio Fair Trade pelo retorno financeiro também é forte. "Desde o início, nossa ideia era ser uma empresa social e lucrativa ao mesmo tempo", ressalta Márcio. A empresa atingiu este objetivo desde o primeiro ano de funcionamento. Seu faturamento é dividido entre os serviços de comercialização de produto por meio de diferentes canais (varejo nacional, varejo internacional, venda de brindes corporativos e venda ao consumidor final) e serviços de consultoria para empresas interessadas em atuar em comércio justo. Uma parte do lucro é reinvestida, outra parte é dividida entre os sócios e outra parte é doada para a ONG Casa da Esperança - que cuida de aproximadamente 130 crianças com idades entre seis meses e 12 anos.

A organização tem uma estrutura organizacional extremamente enxuta sendo contratados colaboradores na medida em que há projetos. A Bio Fair Trade atua hoje em todas as regiões do país. Estima-se que até 2015 mais de três mil artesãos foram beneficiados diretamente 
pela Bio Fair Trade nos estados de AL, BA, PE, RN, MG, MS e MT. No mercado internacional, a empresa fornece produtos para 400 lojas distribuídas na Holanda, Bélgica e Luxemburgo, além de 600 lojas na Alemanha e uma na França. No Brasil, a comercialização dos produtos se dá em lojas varejistas e, em novembro de 2015, foi inaugurada sua primeira loja física, a Vila Mundo, na capital pernambucana, para a venda exclusiva dos produtos da sua rede de artesãos.

Segundo os fundadores, o impacto social causado vai muito além do aumento de renda dos grupos. O empreendimento impacta positivamente a qualidade de vida dos artesãos por aumentar a autoestima ao oferecer reconhecimento social da valorização do trabalho e comercialização no mercado nacional e internacional.

Os dados levantados permitem classificar a Bio Fair Trade como um empreendimento social que estrutura sua atuação de forma bem equilibrada entre uma lógica de mercado e lógica social o que reflete em uma pontuação bem balanceada (-2) de um continuum que varia de 10 a 10 . Vide tabela 18 abaixo.

Tabela 18 - Posicionamento do Empreendimento Social - Bio Fair Trade

\begin{tabular}{|c|c|c|c|}
\hline Fatores & Lógica de Mercodo & $\begin{array}{l}\text { Bio Fair Trade } \\
\text { (PE) }\end{array}$ & Lógica Socid \\
\hline Objetivo principal & Aproveitar uma oportunidade de mercado & 1 & Resolver um problema socioambiental \\
\hline Oferta & $\begin{array}{l}\text { Bens e servicosos voltados para o consumo } \\
\text { da populaçấo }\end{array}$ & -1 & $\begin{array}{l}\text { Bens e serviços voltados para necessidades básicas e/ou } \\
\text { que conservem a biodiversidade }\end{array}$ \\
\hline Intencionalidade & $\begin{array}{l}\text { Geração de valor social é um componente } \\
\text { importante, porém não central }\end{array}$ & 1 & Geração de valor social é o core business do negócio \\
\hline Escala & Fator relevante & -1 & Replicabilidade é mais relevante que a escalabilidade \\
\hline Clientes & $\begin{array}{l}\text { Os dientes pertencem a diversas dasses } \\
\text { sociais }\end{array}$ & -1 & $\begin{array}{l}\text { Predominantemente segmentos da população que estão em } \\
\text { situação de maior vulnerabilidade }\end{array}$ \\
\hline Fornecedores & $\begin{array}{l}\text { Os critérios para escolha são preço e } \\
\text { qualidade }\end{array}$ & 1 & $\begin{array}{l}\text { Procura-se contratar segmentos da população que estão em } \\
\text { situação de maior vulnerabilidade }\end{array}$ \\
\hline Colaboradores & Não há nenhuma prioridade na contratação & -1 & $\begin{array}{l}\text { Prioridade para segmentos da população que estão em situação } \\
\text { de maior vulnerabilidade }\end{array}$ \\
\hline Processo decisório & $\begin{array}{l}\text { Não há mecanismos institucionais para } \\
\text { participação coletiva }\end{array}$ & 1 & $\begin{array}{l}\text { Há mecanismos institucionais para participação coletiva } \\
\text { das comunidades com as quais o empreendimento atua }\end{array}$ \\
\hline Distribuiçōo de lua & Distribuiç̣ao de dividendos. & -1 & Lucro é totalmente investido \\
\hline Valor Econômico & $\begin{array}{l}\text { Todos os recursos são provenientes } \\
\text { de vendas de produtose servicos }\end{array}$ & -1 & $\begin{array}{l}\text { Depende de doações e colaboraçōes institucionais para } \\
\text { desenvolver sua atividade principal }\end{array}$ \\
\hline Total & & -2 & \\
\hline
\end{tabular}

Fonte: elaborada pela autora

As inovações implementadas pela BioFair Trade são de mercado, por meio da diversificação de canais de venda para os artesãos e precificação (os pedidos são feitos com o adiantamento de $50 \%$ do valor ao produtor), e organizacional, levando em conta os treinamentos, assessoria técnica e recursos oferecidos diretamente pela empresa e por seus 
parceiros institucionais. A abrangência da inovação é nacional e a sua profundidade caracterizada como incremental.

Em termos de geração de valor socioambiental, considera-se que os resultados diretos da BioFair Trade são: aumento de renda (capital produtivo) e diminuição de custos de transação (oferecimento de capital de giro aos artesãos). Como benefícios indiretos, destacam-se: aumento da autoestima dos artesãos, desenvolvimento de capital social pelo estímulo a ligação dos grupos sociais originalmente dispersos que passam a interagir e colaborar durante as feiras, seminários e workshops organizados pela empresa, bem como, profissionalização dos artesãos (capital humano).

\subsection{5 - Fazenda Tamanduá (PB)}

A Fazenda Tamanduá, localizada no município pernambucano de Santa Teresinha, é a maior fazenda biodinâmica do Brasil. A área, superior a três mil hectares, é destinada à preservação da vegetação natural do semiárido (caatinga), à pecuária de bovinos e caprinos (alimentados pela vegetação natural) e à produção diversificada de mel, manga, melão e alga spirulina. A alga spirulina era utilizada para medicamentos, mas foi desenvolvida para fins de suplemento alimentar pelos técnicos da Fazenda Tamanduá.

A Fazenda Tamanduá foi criada, em 1977, por Pierre Landolt, um franco-suíço naturalizado brasileiro. Na região era feito, originalmente, o cultivo do algodão mocó em conjunto com a cultura de gado. Porém, a produção do binômio algodão-gado no sistema tradicional declinou com um período de seca entre 1979 e 1984 e a simultânea chegada da praga conhecida como bicudo. A partir daí, Landolt buscou outras opções para continuar produzindo no semiárido. Em 1998, ele decidiu adotar a agricultura orgânica e biodinâmica, pautada na premissa de que uma propriedade rural é um organismo vivo no qual diferentes culturas fornecem insumos umas às outras.

Sustentar uma produção diversificada e orgânica no semiárido nordestino tem seus desafios. Lidar com a erosão e o empobrecimento do solo, causados pelo calor constante, os altos níveis de insolação e o vento forte, é um deles. Para contornar a situação, a organização produz seu próprio adubo a partir da compostagem do esterco de gado e da poda das 
mangueiras. Um segundo desafio é a necessidade de constante capacitação dos colaboradores da fazenda. Landolt estabeleceu parcerias com a Empresa Brasileira de Pesquisa Agropecuária (Embrapa) e a Empresa Estadual de Pesquisa Agropecuária da Paraíba (Emepa) para apoiar pequenos agricultores da região no desenvolvimento de culturas orgânicas e comercialização dessa produção. "O maior desafio do pequeno produtor, mesmo aqui no sertão, não é a produção, mas sim o acesso ao mercado. Trabalhando em conjunto com eles, podemos garantir um volume de produção que nos dá acesso a clientes que, sozinhos, eles não poderiam atender." Dessa forma, Landolt estabeleceu uma cadeia produtiva que vai dos pequenos produtores às grandes redes de varejo. "O mercado brasileiro de produtos orgânicos está crescendo e amadurecendo. Posso dizer que, hoje, não falta mercado, falta escala de produção."

Os dados levantados permitem classificar a Fazenda Tamanduá como um empreendimento que tem preocupação com o mercado, porém busca uma atuação que promove também valor social para região o que reflete em uma pontuação -4 de um continuum que varia de 10 a 10. Vide tabela 19 abaixo:

Tabela 19 - Posicionamento do Empreendimento Social - Fazenda Tamanduá

\begin{tabular}{|c|c|c|c|}
\hline Fatores & Lógica de Mercodo & $\begin{array}{l}\text { Fazenda } \\
\text { Tamanduá } \\
\text { (PE) }\end{array}$ & Lógica Socid \\
\hline Objefivo prinaipal & Aproveitar uma oportunidade de mercado & -1 & Resolver um problema socioambiental \\
\hline Oferta & $\begin{array}{l}\text { Bens e servicos voltados para o consumo } \\
\text { da população }\end{array}$ & 1 & $\begin{array}{l}\text { Bens e serviços voltados para necessidades básicas e/ou } \\
\text { que conservem a biodiversidade }\end{array}$ \\
\hline Intencionalidade & $\begin{array}{l}\text { Geração de valor social é um componente } \\
\text { importante, porém não central }\end{array}$ & -1 & Geração de valor social é o core business do negócio \\
\hline Escala & Fator relevante & -1 & Replicabilidade é mais relevante que a escalabilidade \\
\hline Clientes & $\begin{array}{l}\text { Os dientes pertencem a diversas dasses } \\
\text { sociais }\end{array}$ & -1 & $\begin{array}{l}\text { Predominantemente segmentos da população que estão em } \\
\text { situação de maior vulnerabilidade }\end{array}$ \\
\hline Fornecedores & $\begin{array}{l}\text { Os critérios para escolha são preço e } \\
\text { qualidade }\end{array}$ & 1 & $\begin{array}{l}\text { Procura-se contratar segmentos da população que estão em } \\
\text { situação de maior vulnerabilidade }\end{array}$ \\
\hline Colaboradores & Não há nenhuma prioridade na contratação & 1 & $\begin{array}{l}\text { Prioridade para segmentos da população que estão em situação } \\
\text { de maior vulnerabilidade }\end{array}$ \\
\hline Processo decisório & $\begin{array}{l}\text { Não há mecanismos institucionais para } \\
\text { participaçāo coletiva }\end{array}$ & -1 & $\begin{array}{l}\text { Há mecanismos institucionais para participação coletiva } \\
\text { das comunidades com as quais o empreendimento atua }\end{array}$ \\
\hline Distribuiç̣̂o de luaro & Distribuiçāo de dividendos. & -1 & Lucro é totalmente investido \\
\hline Valor Econômico & $\begin{array}{l}\text { Todos os recursos são provenientes } \\
\text { de vendas de produtose servictos }\end{array}$ & -1 & $\begin{array}{l}\text { Depende de doaçôes e colaboraçōes institucionais para } \\
\text { desenvolver sua atividade principal }\end{array}$ \\
\hline Total & & -4 & \\
\hline
\end{tabular}

Fonte: elaborada pela autora

As inovações implementadas pela Fazenda Tamanduá são de produto, pelo desenvolvimento de novos alimentos utilizando a biodinâmica (ex. algas spirulina) e de processo, pela criação de procedimentos de produção adaptados para região e com reaproveitamento de materiais 
(por exemplo, o adubo). A abrangência da inovação é local de profundidade caracterizada como institucional, pois demonstrou o potencial de plantio em região marcada pela seca.

Em termos de geração de valor socioambiental, considera-se que os principais resultados diretos oferecidos pela Fazenda Tamanduá são: aumento da oferta de capital natural e de alimentos saudáveis (capital humano). Como resultado indireto, destacam-se a geração de conhecimento e renda para produtores locais (capital humano), a diminuição de custos de transação pela eliminação de intermediários e o reaproveitamento de materiais.

\subsection{6 - Rede Xique Xique (RN)}

A Rede Xique Xique de comercialização solidária é uma articulação social baseada na autonomia e solidariedade de seus membros. A rede nasceu da vontade de agricultores em romper com os intermediários na venda e na circulação dos seus produtos, a fim de fortalecer a autogestão e a organização de todos os participantes.

A rede conta com mais de 300 pessoas em grupos espalhados por 12 municípios do Rio Grande do Norte e divididos em três núcleos centrais. Há uma grande diversidade de produtos e serviços comercializados: frutas, hortaliças, mel, pesca, mariscos, bijuterias, artesanato, serviço de buffet, faxina e muitos outros.

Sua história teve início em 1999, quando um grupo de mulheres constituiu uma associação informal, a Associação dos Parceiros e Parceiras da Terra (APT), com o intuito de entregar hortaliças orgânicas para um grupo de clientes em troca do pagamento de uma taxa mensal, eliminando, assim, os intermediários.

Em dezembro de 2003, na cidade de Mossoró, foi inaugurado o Espaço de Comercialização Solidária Xique Xique, que objetivava tornar-se referência no recebimento e escoamento da produção advinda da agricultura familiar da Região Oeste do Rio Grande do Norte. O objetivo era ter uma oferta diversificada, capaz de atrair e fortalecer o consumo solidário em detrimento do acúmulo de lucro pelos intermediários.

Em 2004, foi constituída a Associação de Comercialização Solidária Xique Xique, que visava fortalecer unidades familiares, grupos informais, associações e cooperativas que 
compartilhavam os mesmos princípios: economia solidária, agroecologia e feminismo. A rede busca inserir os grupos produtivos em feiras de agricultura familiar já existentes e, quando necessário, articula a criação de novas feiras, além da entrega de produtos a domicílio e a compra direta.

As decisões da Rede são feitas de forma coletiva, em reuniões trimestrais, com representantes de todos os grupos. Há também um conselho diretor, com representantes dos núcleos, que se reúne mensalmente para discutir assuntos como a elaboração de projetos, participação em fóruns e inscrição em editais. No entanto, cada grupo tem total autonomia interna de gestão e decisão, desde que não haja um desalinhamento de princípios.

Os dados levantados permitem classificar a Rede Xique-Xique como um empreendimento social com uma lógica de atuação com muita ênfase no social, obtendo uma pontuação de 6 (de um total que varia de -10 a 10), conforme apresentado na tabela 20.

Tabela 20 - Posicionamento do Empreendimento Social - Rede Xique Xique

\begin{tabular}{|c|c|c|c|}
\hline Fotores & Lógica de Mercodo & $\begin{array}{l}\text { Rede Xique-Xique } \\
\text { (RN) }\end{array}$ & Lógica Socid \\
\hline Objefivo principal & Aproveitar uma oportunidade de mercado & 1 & Resolver um problema socioambiental \\
\hline Oferta & $\begin{array}{l}\text { Bens e serviços voltados para o consumo } \\
\text { da população }\end{array}$ & -1 & $\begin{array}{l}\text { Bens e serviços voltados para necessidades básicas e/ou } \\
\text { que conservem a biodiversidade }\end{array}$ \\
\hline Intencionalidade & $\begin{array}{l}\text { Geração de valor social é um componente } \\
\text { importante, porém não central }\end{array}$ & 1 & Geração de valor social é o core business do negócio \\
\hline Escala & Fator relevante & 1 & Replicabilidade é mais relevante que a escalabilidade \\
\hline Clientes & $\begin{array}{l}\text { Os dientes pertencem a diversas dasses } \\
\text { sociais }\end{array}$ & -1 & $\begin{array}{l}\text { Predominantemente segmentos da população que estão em } \\
\text { situação de maior vulnerabilidade }\end{array}$ \\
\hline Fornecedores & $\begin{array}{l}\text { Os critérios para escolha são preço e } \\
\text { qualidade }\end{array}$ & 1 & $\begin{array}{l}\text { Procura-se contratar segmentos da população que estão em } \\
\text { situação de maior vulnerabilidade }\end{array}$ \\
\hline Colaberadores & Não há nenhuma prioridade na contratação & 1 & $\begin{array}{l}\text { Prioridade para segmentos da população que estão em situação } \\
\text { de maior vulnerabilidade }\end{array}$ \\
\hline Processo decisório & $\begin{array}{l}\text { Não há mecanismos institucionais para } \\
\text { partiaipação coletiva }\end{array}$ & 1 & $\begin{array}{l}\text { Há mecanismos institucionais para participação coletiva } \\
\text { das comunidades com as quais o empreendimento atua }\end{array}$ \\
\hline Distribuiçōo de loao & Distribuição de dividendos. & 1 & Lucro é totalmente investido \\
\hline Valor Econômico & $\begin{array}{l}\text { Todos os recursos são provenientes } \\
\text { de vendas de produtose servictos }\end{array}$ & 1 & $\begin{array}{l}\text { Depende de doaçôes e colaboraçōes institucionais para } \\
\text { desenvolver sua atividade principal }\end{array}$ \\
\hline Total & & 6 & \\
\hline
\end{tabular}

Fonte: elaborada pela autora

As inovações implementadas pela Rede Xique-Xique podem ser observadas em duas categorias: mercadológica (diversificação dos canais de venda e criação de marca própria) e organizacional (aliança estratégica de grupos produtores). A abrangência da inovação é regional. Pode-se dizer que a inovação implementada tem um caráter institucional, visto que reconfigura a forma de atuação de grupos informais em uma região com incidência de muita 
pobreza. A Rede Xique-Xique mostra a viabilidade da atuação conjunta de organizações de economia solidária.

Em termos de geração de valor socioambiental, considera-se que os benefícios diretos da rede Xique-Xique são: geração de renda (capital produtivo), eliminação de intermediários (custos de transação) e aumento do capital social por meio da criação da rede de uma colaboração solidária.

\subsection{7 - Banco Palmas (CE)}

O Banco Palmas é o primeiro Banco Comunitário de Desenvolvimento (BCD) do Brasil. Foi criado, em 1998, no Conjunto Palmeiras, na periferia de Fortaleza, no Ceará, por meio da liderança de Joaquim Melo.

Um Banco Comunitário de Desenvolvimento diferencia-se de bancos tradicionais pelo seu objetivo de desenvolver a comunidade na qual está inserido, oferecendo serviços financeiros que apoiam o desenvolvimento de empreendedores locais e incentivando moradores a consumir na própria comunidade.

O Banco Palmas opera em uma comunidade onde sequer existem agências bancárias, na qual os moradores e empreendedores raramente cumprem os requisitos de concessão de crédito dos bancos tradicionais. Assim como os outros BCDs, o Palmas oferece à população serviços de correspondente bancário, microsseguros, linhas de crédito produtivo e uma linha de crédito de consumo, esta última oferecida em moeda social, uma moeda criada pela comunidade para ser utilizada apenas dentro do bairro.

A criação e a gestão da circulação de moeda social é o elemento inovador mais palpável de um BCD. No Conjunto das Palmeiras, o Palma (como é chamada a moeda social do Banco Palmas) é aceito por dezenas de comerciantes que oferecem descontos e outras promoções para quem o utiliza. Assim, estimula-se o consumo local. Após mais de 15 anos de sua fundação, cerca de $93 \%$ do consumo do Conjunto Palmeiras é realizado dentro do bairro. Os 60 mil Palmas em circulação são símbolos vivos da importância desse consumo para o desenvolvimento endógeno da comunidade. 
O banco possui um conselho comunitário, eleito a partir de um Fórum Socioeconômico de Desenvolvimento Local (FECOL), que funciona tal qual o conselho de uma grande empresa: toma decisões estratégicas e acompanha suas atividades. Operacionalmente, um bom exemplo do caráter comunitário do banco é o aval de vizinhança para os créditos. Joaquim esclarece: "para qualquer morador do bairro ter acesso a crédito, por exemplo, é feita uma consulta aos seus vizinhos para verificar se aquela é uma pessoa confiável".

Outro diferencial da abordagem do Banco Palmas reside em seu foco no desenvolvimento local - a manutenção do dinheiro na comunidade e o apoio a iniciativas endógenas de empreendedorismo, dimensões não trabalhadas por iniciativas que focam apenas na concessão de crédito.

O Banco Palmas está desenvolvendo o projeto Banco da Periferia que seria uma rede de BCDs interligados que colaboram entre si no desenvolvimento de novos produtos e compartilham serviços de backoffice (reduzindo, assim, custos de operação): "Esse é o futuro dos BCDs. Isolados, tendemos a minguar...Imagine milhares de bancos comunitários pelo Brasil, conectando comunidades por fluxos econômicos. Quando fizermos isso, estaremos criando um grande corredor comercial de economia solidária, fortalecendo as economias populares", comenta Joaquim.

Os dados levantados permitem classificar o Banco Palmas como exemplo de um empreendimento social que tem lógica de atuação com total ênfase no social, obtendo a pontuação máxima de 10 , conforme apresentado na tabela 21 a seguir. 
Tabela 21 - Posicionamento do Empreendimento Social - Banco Palmas

\begin{tabular}{|c|c|c|c|}
\hline Fotores & Lógica de Mercodo & $\begin{array}{l}\text { Banco Palmas } \\
\text { (CE) }\end{array}$ & Lógica Socid \\
\hline Objetivo prinaipal & Aproveitar uma oportunidade de mercado & 1 & Resolver um problema socioambiental \\
\hline Oferta & $\begin{array}{l}\text { Bens e serviços voltados para o consumo } \\
\text { da populaçāo }\end{array}$ & 1 & $\begin{array}{l}\text { Bens e serviços voltados para necessidades básicas e/ou } \\
\text { que conservem a biodiversidade }\end{array}$ \\
\hline Intencionalidade & $\begin{array}{l}\text { Geração de valor social é um componente } \\
\text { importante, porém nõo central }\end{array}$ & 1 & Geração de valor social é o core business do negócio \\
\hline Escala & Fator relevante & 1 & Replicabilidade é mais relevante que a escalabilidade \\
\hline Clientes & $\begin{array}{l}\text { Os dientes pertencem a diversas dasses } \\
\text { sociais }\end{array}$ & 1 & $\begin{array}{l}\text { Predominantemente segmentos da população que estão em } \\
\text { situação de maior vulnerabilidade }\end{array}$ \\
\hline Fornecedores & $\begin{array}{l}\text { Os critérios para escolha são preço e } \\
\text { qualidade }\end{array}$ & 1 & $\begin{array}{l}\text { Procura-se contratar segmentos da população que estão em } \\
\text { situação de maior vulnerabilidade }\end{array}$ \\
\hline Colaboradores & Não há nenhuma prioridade na contratação & 1 & $\begin{array}{l}\text { Prioridade para segmentos da população que estão em situação } \\
\text { de maior vulnerabilidade }\end{array}$ \\
\hline Processo decisório & $\begin{array}{l}\text { Não há mecanismos institucionais para } \\
\text { participação coletiva }\end{array}$ & 1 & $\begin{array}{l}\text { Há mecanismos institucionais para participação coletiva } \\
\text { das comunidades com as quais o empreendimento atua }\end{array}$ \\
\hline Distribuiç̣̄o de loaro & Distribuição de dividendos. & 1 & Lucro é totalmente investido \\
\hline Valor Econômico & $\begin{array}{l}\text { Todos os recursos são provenientes } \\
\text { de vendas de produtose servictos }\end{array}$ & 1 & $\begin{array}{l}\text { Depende de doaçōes e colaboraçōes institucionais para } \\
\text { desenvolver sua atividade principal }\end{array}$ \\
\hline Total & & 10 & \\
\hline
\end{tabular}

Fonte: elaborada pela autora

Para conduzir uma estratégia mais ampla de desenvolvimento local, o Banco Palmas é gerido pelo Instituto Palmas, uma organização social, sem fins lucrativos, que capta recursos por meio de doações de pessoas e empresas. Esses recursos são destinados à realização de uma série de iniciativas complementares e, ao mesmo tempo, essenciais para o desenvolvimento local, incluindo a organização da comunidade, formação profissionalizante dos moradores, capacitação de empreendedores e a educação financeira dos moradores.

O Banco Palmas implementou inovações nas quatro categorias: produto/serviço (exemplo moeda social), mercado (forma de distribuição de produtos e serviços financeiros por meio de agentes comunitários), processo (cobrança por agentes comunitários e aval solidário de crédito) e organizacional (cooperação entre bancos de periferia). A abrangência da inovação é local e a profundidade da inovação é elevada, levando em conta o desenvolvimento provocado na região pela circulação da moeda própria que acelerou o dinamismo econômico local. Nesse sentido, é possível considerar que o potencial da inovação como disruptiva.

Em termos de geração de valor socioambiental, considera-se que os benefícios diretos do Banco Palmas são: diminuição de custos de transação pelo acesso ao crédito e aumento do capital social. De forma indireta, gerou oportunidades de trabalho na localidade (capital produtivo) e elevou a autoestima da população. 


\subsection{8 - Cooperativa de Artesanato de Poty Velho - Cooperart-Poty (PI)}

A Cooperativa de Artesanato de Poty Velho (Cooperart - Poty) fica localizada no Polo Cerâmico de Poty Velho, um bairro em Teresina, no Piauí. A cooperativa possui 39 cooperadas e tem como principal atividade a criação, produção e venda de peças artesanais de cerâmica. A cooperativa nasceu, após esforços de sua fundadora, Raimunda Teixeira, com o objetivo de proporcionar melhores condições de vida e bem-estar para as mulheres da região, por meio da inclusão das mesmas em atividades de artesanato com cerâmica. Até então, tal atividade era predominantemente masculina. Para as mulheres, sobrava o pesado trabalho de carregar tijolos na olaria.

Em 2004, no papel de líder da Associação dos Ceramistas do Poty Velho (Acepoti), Raimunda articulou junto ao Sebrae um curso de modelagem de bijuterias em cerâmica, cujo públicoalvo eram trabalhadoras da olaria, donas de casa e esposas de pescadores. Esperava-se, desta maneira, incluir no polo cerâmico as mulheres oprimidas do bairro. Várias das participantes do treinamento aprenderam a fazer "continhas de barro" e se organizaram para fundar a Cooperart-Poty em 2006, mesmo ano de fundação do Polo Cerâmico.

O Polo Cerâmico é composto por 51 oficinas e 284 famílias que transformam argila em arte. A Cooperart-Poty destaca-se por criar coleções de peças de cerâmica com uma forte identidade cultural local. Um exemplo disso é a coleção de bonecas "Mulheres do Poty", o carro-chefe da cooperativa, composta por cinco bonecas que fazem alusão à origem das cooperadas: a Mulher Religiosa, a Mulher do Pescador, a Mulher da Olaria, a Mulher Ceramista e a Mulher das Continhas. A cultura local é usada como uma vantagem competitiva. Por isso, há a preocupação de se incluir uma etiqueta em todos os produtos, contando quem é a artesã e de onde ela vem.

Outra diferença das artesãs é a busca constante de inovações. O portfólio da cooperativa é constituído por produtos já dominados por todas as artesãs (60\%), produtos relativamente novos dos quais já há um pouco de domínio (30\%), e produtos totalmente novos, dos quais não se tem domínio (10\%). O treinamento, portanto, é visto como prioridade.

A cooperativa possui somente uma loja no Polo Cerâmico, mas conta também com o auxílio do Sebrae na comercialização de produtos em suas lojas terceirizadas. Os produtos são 
enviados para estas lojas e o que não é vendido retorna à cooperativa, com o frete subsidiado pelo Sebrae. Além disso, há também vendas significativas de brindes corporativos para grandes empresas e a participação em feiras da região.

A Cooperart-Poty remunera as artesãs de acordo com a produção e venda de cada artesã: quando um produto é vendido, a artesã que o confeccionou recebe por seu trabalho. Similarmente, quando produtos feitos por mais de uma artesã é vendido, seu valor é distribuído igualmente entre as cooperadas que participaram da produção do artefato. Desta maneira, busca-se respeitar e remunerar de maneira justa as artesãs, com seus diferentes ritmos de produção e aspirações. Do faturamento total, $10 \%$ é destinado à manutenção e ao pagamento dos gastos da cooperativa.

Por ser uma cooperativa fundada dentro dos princípios da economia solidária, a CooperartPoty foi classificada como um empreendimento social com uma lógica de atuação com ênfase no social, obtendo uma pontuação de 4 (de um total que varia de -10 a 10), conforme apresentado na tabela 22.

Tabela 22 - Posicionamento do Empreendimento Social - Cooperart-Poty

\begin{tabular}{|c|c|c|c|}
\hline Fotores & Lógica de Mercodo & $\begin{array}{l}\text { Cooperart-Poty } \\
\text { (PI) }\end{array}$ & Lógica Socid \\
\hline Objetivo principal & Aproveitar uma oportunidade de mercado & 1 & Resolver um problema socioambiental \\
\hline Oferta & $\begin{array}{l}\text { Bens e servicos voltados para o consumo } \\
\text { da população }\end{array}$ & -1 & $\begin{array}{l}\text { Bens e serviços voltados para necessidades básicas e/ou } \\
\text { que conservem a biodiversidade }\end{array}$ \\
\hline Intencionalidade & $\begin{array}{l}\text { Geração de valor social é um componente } \\
\text { importante, porém não central }\end{array}$ & 1 & Geração de valor social é o core business do negócio \\
\hline Escala & Fator relevante & 1 & Replicabilidade é mais relevante que a escalabilidade \\
\hline Clientes & $\begin{array}{l}\text { Os dientes pertencem a diversas dasses } \\
\text { sociais }\end{array}$ & -1 & $\begin{array}{l}\text { Predominantemente segmentos da população que estão em } \\
\text { situação de maior vulnerabilidade }\end{array}$ \\
\hline Fornecedores & $\begin{array}{l}\text { Os critérios para escolha são preço e } \\
\text { qualidade }\end{array}$ & 1 & $\begin{array}{l}\text { Procura-se contratar segmentos da população que estão em } \\
\text { situacãōo de maior vulnerabilidade }\end{array}$ \\
\hline Colaboradores & Não há nenhuma prioridade na contratação & 1 & $\begin{array}{l}\text { Prioridade para segmentos da populaçāo que estão em situação } \\
\text { de maior vulnerabilidade }\end{array}$ \\
\hline Processo decisório & $\begin{array}{l}\text { Não há mecanismos institucionais para } \\
\text { participacão coletiva }\end{array}$ & 1 & $\begin{array}{l}\text { Há mecanismos institucionais para participação coletiva } \\
\text { das comunidades com as quais o empreendimento atua }\end{array}$ \\
\hline Distribuiç̣ōo de loro [ & Distribuição de dividendos. & -1 & Lucro é totalmente investido \\
\hline Valor Econômico & $\begin{array}{l}\text { Todos os recursos são provenientes } \\
\text { de vendas de produtose servicios }\end{array}$ & 1 & $\begin{array}{l}\text { Depende de doaçōes e colaboraçōes institucionais para } \\
\text { desenvolver sua atividade prinçpal }\end{array}$ \\
\hline Total & & 4 & \\
\hline
\end{tabular}

Fonte: elaborada pela autora

A inovação implementada pela Cooperart-Poty é tipicamente organizacional visto que possibilitou compartilhamento de aprendizado entre as mulheres para o desenvolvimento de produtos com muita identidade cultural. A abrangência da inovação é local, sendo a sua profundidade caracterizada como incremental. 
Em termos de geração de valor socioambiental, considera-se que os resultados diretos da Cooperart-Poty são: geração de renda a produtores locais (capital produtivo), eliminação de intermediários (diminuição de custos de transação) pela existência de uma loja própria, bem como o aumento da autoestima das mulheres que passaram a ter uma identidade profissional. De forma indireta, a Cooperart possibilitou aumento do capital humano pela oferta de curso profissionalizante e aumento do capital social na região. Como ressaltou Raimunda Teixeira: "Eu ficava o dia inteiro carregando tijolos no sol para, ao final do dia, ganhar $R \$ 10,00$ (...) Foram 22 anos carregando tijolos até que eu percebi que poderia fazer algo diferente".

\subsection{9 - Fruta Sã (MA)}

A Fruta Sã Indústria, Comércio e Exportação S.A foi fundada, em 1994, com a finalidade de gerar renda para comunidade indígena por meio da produção de polpas congeladas de frutas do cerrado. Sua sede é em Carolina, uma pequena cidade do sul do Maranhão. De fato, a própria concepção da empresa é única, sendo resultado da união de duas organizações, uma indígena e outra indigenista. Juntos, a Associação Wyty Catë dos Povos Timbira do Maranhão e Tocantins e o Centro de Trabalho Indigenista (CTI) perceberam que a manutenção das culturas e do bem-estar dos indígenas da região passava, necessariamente, pela conservação do meio em que eles vivem (o cerrado, o segundo maior bioma do Brasil, que abrange $22 \%$ do território nacional) e pela geração de renda para essas comunidades.

O seu diferencial é o portifólio de 12 frutas - que inclui espécies exclusivas do cerrado, como cajá, bacuri, araçá, cagaita e murici - sem adição de conservantes ou corantes, o que mantem suas polpas totalmente naturais. A empresa conta com cerca de 250 fornecedores de frutas, em sua grande maioria pessoas físicas. São pequenos agricultores e pessoas que coletam frutas do quintal da própria casa, e indígenas que encontraram na Fruta Sã uma oportunidade de complementação de renda, pois a empresa realiza uma composição de preço que permite pagar mais a seus fornecedores. "Pagamos o preço justo pelas frutas. Enquanto outros pagam $R \$ 7$ por um saco de tamarindo, nós pagamos $R \$ 30$. Não fazemos isso por bondade, mas porque é viável para a Fruta Sã", afirma Mayk Arruda, 32, 
coordenador de projetos do CTI, em Carolina, responsável por promover a integração da Fruta Sã com indígenas e pequenos agricultores.

Em 2008, houve um problema técnico que fez a empresa perder toda sua produção de polpa e a organização ficou quase 12 meses sem ter condições de operar. Em 2010, a empresa recebeu dois novos sócios holandeses: o Interchurch Organization for Development Cooperation (ICCO), um órgão holandês de cooperação e Delidor Delicatessen B.V. Além de parte dos recursos para a recuperação financeira da empresa, os novos sócios trouxeram também capital humano para profissionalizar a administração da empresa. "A Fruta Sã é a concretização de uma nova forma de cooperação da ICCO, na qual ela toma parte do negócio para ajudá-lo a se estruturar", explica Geert Haveman, 55, gerente geral da Fruta Sã.

Geert, que residiu no Brasil por muito tempo (era agricultor em Minas Gerais) antes de voltar à Holanda, resume a filosofia da parceria: "Voltei ao Brasil porque acredito no modelo de desenvolvimento de esforço conjunto. Sempre temos que partir das necessidades e aptidões locais e não simplesmente inserir uma fábrica pronta que não corresponde à realidade do lugar. Por isso, aqui na Fruta Sã, o produtor também deve estar inserido no processo de forma que cada um tenha clareza de suas responsabilidades".

Os dados levantados permitem classificar a Fruta Sã como um empreendimento social com uma lógica de atuação com ênfase no social, obtendo uma pontuação de 4 (de um total que varia de -10 a 10), conforme apresentado na tabela 23.

É possível observar dois tipos de inovação na Fruta Sã: produto, levando em conta que inseriu no mercado polpas de frutas do Cerrado, e organizacional, pela forma de atuação com comunidades indígenas. A abrangência da inovação é local e sua profundidade caracterizada como incremental, pois aproveita uma lacuna de mercado, mas não reconfigura seu segmento. 
Tabela 23 - Posicionamento do Empreendimento Social - Fruta Sã

\begin{tabular}{|c|c|c|c|}
\hline Fatores & Lógica de Wercodo & $\begin{array}{l}\text { Fruta Sã } \\
\text { (MA) }\end{array}$ & Lógica Socid \\
\hline Objetivo principal & Aproveitar uma oportunidade de mercado & 1 & Resolver um problema socioambiental \\
\hline Oferta & $\begin{array}{l}\text { Bens e serviços voltados para o consumo } \\
\text { da população }\end{array}$ & -1 & $\begin{array}{l}\text { Bens e serviços voltados para necessidades básicas e/ou } \\
\text { que conservem a biodiversidade }\end{array}$ \\
\hline Intencionalidade & $\begin{array}{l}\text { Geração de valor social é um componente } \\
\text { importante, porém não central }\end{array}$ & 1 & Geração de valor social é o core business do negócio \\
\hline Escala & Fator relevante & 1 & Replicabilidade é mais relevante que a escalabilidade \\
\hline Clientes & $\begin{array}{l}\text { Os dientes pertencem a diversas dasses } \\
\text { sociais }\end{array}$ & -1 & $\begin{array}{l}\text { Predominantemente segmentos da população que estão em } \\
\text { situaçāo de maior vulnerabilidade }\end{array}$ \\
\hline Fornecedores & $\begin{array}{l}\text { Os critérios para escolha são preço e } \\
\text { qualidade }\end{array}$ & 1 & $\begin{array}{l}\text { Procura-se contratar segmentos da população que estão em } \\
\text { situação de maior vulnerabilidade }\end{array}$ \\
\hline Colaboradores & Não há nenhuma prioridade na contratação & 1 & $\begin{array}{l}\text { Prioridade para segmentos da população que estão em situação } \\
\text { de maior vulnerabilidade }\end{array}$ \\
\hline Processo decisório & $\begin{array}{l}\text { Não há mecanismos institucionais para } \\
\text { participaçāo coletiva }\end{array}$ & 1 & $\begin{array}{l}\text { Há mecanismos institucionais para participação coletiva } \\
\text { das comunidades com as quais o empreendimento atua }\end{array}$ \\
\hline Distribuiç̣̄o de loaro & Distribuição de dividendos. & 1 & Lucro é totalmente investido \\
\hline Valor Econômico & $\begin{array}{l}\text { Todos os recursos são provenientes } \\
\text { de vendas de produtose serviços }\end{array}$ & -1 & $\begin{array}{l}\text { Depende de doações e colaboraçōes institucionais para } \\
\text { desenvolver sua atividade principal }\end{array}$ \\
\hline Tofal & & 4 & \\
\hline
\end{tabular}

Fonte: elaborada pela autora

Em termos de geração de valor socioambiental, considera-se que as contribuições diretas da Fruta Sã são geração de renda a produtores locais (capital produtivo) e aumento do capital natural por estimular a conservação da biodiversidade do cerrado. O aumento da renda está diretamente relacionado à eliminação de intermediários (diminuição de custos de transação). A Fruta Sã também possibilita o aumento do capital social pelo compartilhamento de informações entre as comunidades indígenas e aumento do capital humano pela oferta de um produto saudável sem agrotóxico.

\section{5 - Região Norte}

\subsection{1 - Associação de Catadores e Catadoras de Mat.Recicláveis de Palmas - Ascampa (TO)}

A Associação de Catadores e Catadoras de Materiais Recicláveis da Região Norte de Palmas (Ascampa) foi fundada em 2005 na cidade de Palmas, no Tocantins. O principal motivador da criação da associação foi unificar a negociação com os atravessadores, visando aumentar o poder de barganha e valorizar o trabalho dos catadores da região. Como ressaltou a presidente da associação na época do levantamento (2014), Terezinha de Jesus, "antes da associação, vendíamos o quilo do papelão por $R \$$ 0,03. Hoje, conseguimos subir o preço do papelão para $R \$ 0,32 . "$ 
Com a valorização dos materiais vendidos, os catadores da Ascampa conseguem obter dois salários mínimos por mês. A associação conta com 40 catadores, sendo que 12 deles, além de coletar os resíduos recicláveis, trabalham também no armazenamento, triagem e prensagem do material. A associação recolhe o material reciclável das escolas e das casas do bairro, recebe o material coletado pelo supermercado local e realiza a coleta seletiva municipal em duas quadras da cidade, em caráter experimental.

A Ascampa foi classificada como um empreendimento social com uma lógica de atuação com muita ênfase no social, obtendo uma pontuação de 6 (de um total que varia de -10 a 10), conforme apresentado na tabela 24.

Tabela 24 - Posicionamento do Empreendimento Social - Ascampa

\begin{tabular}{|c|c|c|c|}
\hline Fotores & Lógica de Mercodo & $\begin{array}{l}\text { Ascampa } \\
\text { (TO) }\end{array}$ & Lógica Socid \\
\hline Objetivo prinaipal & Aproveitar uma oportunidade de mercado & 1 & Resolver um problema socioambiental \\
\hline Oferta & $\begin{array}{l}\text { Bens e serviços voltados para o consumo } \\
\text { da populaçāo }\end{array}$ & -1 & $\begin{array}{l}\text { Bens e serviços voltados para necessidades básicas e/ou } \\
\text { que conservem a biodiversidade }\end{array}$ \\
\hline Intencionalidade & $\begin{array}{l}\text { Geraçāo de valor social é um componente } \\
\text { importante, porém não central }\end{array}$ & 1 & Geração de valor social é o core business do negócio \\
\hline Escala & Fator relevante & 1 & Replicabilidade é mais relevante que a escalabilidade \\
\hline Clientes & $\begin{array}{l}\text { Os dientes pertencem a diversas dasses } \\
\text { sociais }\end{array}$ & -1 & $\begin{array}{l}\text { Predominantemente segmentos da população que estão em } \\
\text { situação de maior vulnerabilidade }\end{array}$ \\
\hline Fornecedores & $\begin{array}{l}\text { Os critérios para escolha são preço e } \\
\text { qualidade }\end{array}$ & 1 & $\begin{array}{l}\text { Procura-se contratar segmentos da populaçāo que estão em } \\
\text { situação de maior vulnerabilidade }\end{array}$ \\
\hline Colaboradores & Não há nenhuma prioridade na contratação & 1 & $\begin{array}{l}\text { Prioridade para segmentos da população que estão em situação } \\
\text { de maior vulnerabilidade }\end{array}$ \\
\hline Processo decisório & $\begin{array}{l}\text { Não há mecanismos institucionais para } \\
\text { participação coletiva }\end{array}$ & 1 & $\begin{array}{l}\text { Há mecanismos institucionais para participaccão coletiva } \\
\text { das comunidades com as quais o empreendimento atua }\end{array}$ \\
\hline Distribuiç̣̄o de luaro & Distribuição de dividendos. & 1 & Lucro é totalmente investido \\
\hline Valor Econômico & $\begin{array}{l}\text { Todos os recursos são provenientes } \\
\text { de vendas de produtose servicicos }\end{array}$ & 1 & $\begin{array}{l}\text { Depende de doações e colaborações institucionais para } \\
\text { desenvolver sua atividade principal }\end{array}$ \\
\hline Total & & 6 & \\
\hline
\end{tabular}

Fonte: elaborada pela autora

A atuação da Ascampa não é diferente de outras associações/cooperativas de catadores. No entanto, seu modelo organizacional foi inovador para a localidade que não tinha nenhuma outra associação do mesmo gênero. Por este motivo, classifica-se a inovação como organizacional, porém de abrangência local e de profundidade incremental.

Em termos de geração de valor socioambiental, considera-se que os resultados diretos da Ascampa são: o incremento da geração de renda dos catadores (capital produtivo), a eliminação de intermediários (diminuição de custos de transação) e em termos ambientais pelo reaproveitamento de materiais. Como toda associação de catadores, a Ascampa possibilita o fortalecimento do capital social e da autoestima dos catadores que passam a ter uma identidade profissional. 


\subsection{2 - 100\% Amazônia (PA)}

A 100\% Amazônia é uma empresa especializada em desenvolver e exportar ingredientes de produtos florestais não madeireiros da Floresta Amazônica. Fernanda Stefani, uma de suas fundadoras, diz que somente depois de sair do Brasil conseguiu perceber e valorizar toda a riqueza da floresta. Após voltar da Áustria, onde morou por oito anos, estudou Ciências Comerciais e se especializou em Inteligência Comercial e Comércio Exterior. Trabalhava em uma multinacional norte-americana que comercializava produtos à base de açaí, quando teve seu primeiro contato com a Amazônia e toda sua riqueza.

Com a experiência adquirida neste período, ela aprendeu que não aproveitar o potencial econômico da Floresta Amazônica de maneira sustentável contribui para a intensificação do desmatamento e do emprego predatório de sua biodiversidade. Fernanda acredita que se a população local conseguir utilizar os recursos da floresta para obter uma boa renda para suas famílias, ela própria se dedicará a preservá-la como sua guardiã para o futuro.

Fernanda e a administradora de empresas Joziane Alves fundaram, em 2006, a $100 \%$ Amazônia. A empresa conecta produtores locais da Amazônia com clientes estrangeiros interessados em seus produtos. Ela garante um preço justo aos produtores e gerencia a logística de exportação para os clientes. A 100\% Amazônia trabalha com uma ampla variedade de produtos da floresta, tendo o açaí como carro chefe, responsável por cerca de $60 \%$ de seu faturamento.

Um fato interessante sobre o açaí é que sua produção é maior quando plantado em floresta nativa. A extração do fruto, portanto, colabora para a preservação da floresta. Além disso, $100 \%$ do açaí é aproveitado: a semente pode ser usada no artesanato e também na geração de energia; a polpa é usada na indústria alimentícia; e a raiz, na farmacêutica.

A "super-fruta" tem despertado forte interesse de clientes de todo o mundo. A empresa já atendeu mais de 300 clientes de 25 países. Toda essa procura é refletida também em resultados financeiros, pois, desde seu primeiro ano, a 100\% Amazônia dobra seu faturamento anualmente.

Além de atender aos mercados tradicionais de exportação (Estados Unidos, Europa Ocidental e China), a 100\% Amazônia chega também a mercados não tradicionais, como 
Polônia, Romênia, Filipinas, Malásia, Nova Zelândia, Paquistão e Qatar. Atender a esses mercados traz desafios logísticos significativos, uma vez que, em geral, os pedidos vindos desses lugares são pequenos para um modelo de exportação tradicional. Por isso, a 100\% Amazônia desenvolveu uma série de parcerias com operadores logísticos, o que lhe permite entregar remessas com menos de $100 \mathrm{~kg}$ na porta do cliente em qualquer lugar do mundo.

Mas, a empresa vai além de colocar o produto na porta do cliente em quantidades pequenas. Sua estratégia comercial busca entender a realidade do cliente, o que inclui decifrar as normas de importação do país de destino, pesquisar sabores locais que possam tornar os sabores das frutas amazônicas mais familiares ao paladar local e criar serviços de suporte à comercialização dos produtos, como, por exemplo, a elaboração de peças publicitárias com cenas e imagens originais da Amazônia. Assim, busca ser a solução completa para produtos da Amazônia. Essa aspiração é reforçada pelo próprio slogan "The one-stop shop for amazon products".

Os dados levantados permitem classificar a 100\% Amazônia como um empreendimento com uma lógica clara de mercado, obtendo uma pontuação - 8 (de um total que varia de -10 a 10), conforme apresentado na tabela 25.

A inovação implementada pela 100\% Amazônia é mercadológica visto que abriu oportunidades de venda de produtos da Amazônia para mercados não tradicionais. A abrangência da inovação é regional e sua profundidade incremental.

Em termos de geração de valor socioambiental, considera-se que o benefício direto da $100 \%$ Amazônia está relacionado à preservação da floresta em pé (capital natural) e geração de renda a produtores locais (capital produtivo). Como benefícios indiretos, a elevação da autoestima e da consciência ambiental dos produtores, que se sentem valorizados pela comercialização de produtos nativos. 
Tabela 25 - Posicionamento do Empreendimento Social - 100\% Amazônia

\begin{tabular}{|c|c|c|c|}
\hline Fotores & Lógica de Wercodo & $\begin{array}{l}\text { 100\% Amazônia } \\
\text { (PA) }\end{array}$ & Lógica Socid \\
\hline Objefivo prinajpal & Aproveitar uma oportunidade de mercado & -1 & Resolver um problema socioambiental \\
\hline Oferta & $\begin{array}{l}\text { Bens e servicicos voltados para o consumo } \\
\text { da população }\end{array}$ & -1 & $\begin{array}{l}\text { Bens e serviços voltados para necessidades básicas e/ou } \\
\text { que conservem a biodiversidade }\end{array}$ \\
\hline Intencionolidade & $\begin{array}{l}\text { Geraçāo de valor social é um componente } \\
\text { importante, porém não central }\end{array}$ & -1 & Geração de valor social é o core business do negócio \\
\hline Escala & Fator relevante & -1 & Replicabilidade é mais relevante que a escalabilidade \\
\hline Clientes & $\begin{array}{l}\text { Os dientes pertencem a diversas dasses } \\
\text { sociais }\end{array}$ & -1 & $\begin{array}{l}\text { Predominantemente segmentos da população que estão em } \\
\text { situação de maior vulnerabilidade }\end{array}$ \\
\hline Fornecedores & $\begin{array}{l}\text { Os critérios para escolha são preço e } \\
\text { qualidade }\end{array}$ & 1 & $\begin{array}{l}\text { Procura-se contratar segmentos da população que estão em } \\
\text { situação de maior vulnerabilidade }\end{array}$ \\
\hline Colaboradores & Não há nenhuma prioridade na contratação & -1 & $\begin{array}{l}\text { Prioridade para segmentos da população que estão em situação } \\
\text { de maior vulnerabilidade }\end{array}$ \\
\hline Processo decisório & $\begin{array}{l}\text { Não há mecanismos institucionais para } \\
\text { participacão coletiva }\end{array}$ & -1 & $\begin{array}{l}\text { Há mecanismos institucionais para participacão coletiva } \\
\text { das comunidades com as quais } 0 \text { empreendimento atua }\end{array}$ \\
\hline Distribuiç̣̄o de loaro & Distribuição de dividendos. & -1 & Lucro é totalmente investido \\
\hline Valor Econômico & $\begin{array}{l}\text { Todos os recursos são provenientes } \\
\text { de vendas de produtose servictos }\end{array}$ & -1 & $\begin{array}{l}\text { Depende de doaçōes e colaboraçōes institucionais para } \\
\text { desenvolver sua atividade principal }\end{array}$ \\
\hline Tofal & & -8 & \\
\hline
\end{tabular}

Fonte: elaborada pela autora

\subsection{3 - Cooperativa Mista dos Produtores e Extrativistas do Rio Iratapuru - Comaru (AP)}

A Cooperativa Mista dos Produtores e Extrativistas do Rio Iratapuru (Comaru) fica localizada na Vila São Francisco do Rio Iratapuru, no município de Laranjal do Jari, no Amapá (AP). Sua principal atividade é a produção e venda do óleo de castanha do Brasil (também denominada castanha do Pará). A cooperativa foi fundada, em 1992, com o intuito de possibilitar uma melhor negociação dos preços dos castanheiros da região. Antes da fundação da cooperativa, os castanheiros viviam de forma isolada e, por isso, o contato com as outras famílias era pequeno. Cada castanheiro vendia sua produção individualmente para atravessadores, seguindo a lógica do financiamento: o produto era vendido antes mesmo do início do ciclo de coleta, a fim de garantir a sobrevivência destes trabalhadores no período de entressafra. Individualmente, tinham pouco poder de barganha com os atravessadores da comercialização da castanha, que determinavam um valor de compra muito baixo.

A cooperativa iniciou suas atividades produzindo biscoitos de castanha do Brasil, consumidos em larga escala na merenda escolar da região. Após um incêndio na fábrica, em 2003, que destruiu todos os equipamentos, a cooperativa mudou seu foco. Com a falta de apoio do governo estadual, que não mais compraria os biscoitos, e a aproximação de uma 
multinacional de cosméticos, a fábrica foi reconstruída e passou a voltar-se à produção do óleo biológico da castanha. Além disso, a cooperativa passou, também, a dedicar-se à coleta do breu branco (resina expelida por uma espécie de árvore encontrada na Floresta Amazônica), fornecido à mesma empresa.

A parceria da cooperativa com a multinacional foi estabelecida por meio de um contrato de longo prazo, garantindo a compra do óleo da castanha. A empresa também destina $0,5 \%$ da receita líquida da venda dos produtos que usam ingredientes da Comaru para um fundo destinado a projetos de desenvolvimento sustentável para a comunidade.

A Comaru garante o sustento de cerca de 250 pessoas que se dividem em trabalhos de coleta da matéria prima, extração e processamento do óleo e atividades de administração. Um dos grandes desafios da Cooperativa é diminuir a dependência de um único cliente. Para isso, será necessário diversificar a produção, particularmente na fabricação de produtos alimentícios a partir da torta da castanha, material remanescente do processamento.

Por ser uma cooperativa fundada a partir dos princípios da Economia Solidária, a Comaru foi classificada como um empreendimento social com uma lógica de atuação com ênfase no social, obtendo uma pontuação de 4 (de um total que varia de -10 a 10), conforme apresentado na tabela 26.

Tabela 26 - Posicionamento do Empreendimento Social - Comaru

\begin{tabular}{|c|c|c|c|}
\hline Fotores & Lógica de Wlercodo & $\begin{array}{c}\text { Comaru } \\
\text { (AP) }\end{array}$ & Lógica Socid \\
\hline Objefivo principal & Aproveitar uma oportunidade de mercado & 1 & Resolver um problema socioambiental \\
\hline Oferta & $\begin{array}{l}\text { Bens e serviços voltados para o consumo } \\
\text { da população }\end{array}$ & -1 & $\begin{array}{l}\text { Bens e serviços voltados para necessidades básicas e/ou } \\
\text { que conservem a biodiversidade }\end{array}$ \\
\hline Intencionalidade & $\begin{array}{l}\text { Geração de valor social é um componente } \\
\text { importante, porém não central }\end{array}$ & 1 & Geração de valor social é o core business do negócio \\
\hline Escala & Fator relevante & 1 & Replicabilidade é mais relevante que a escalabilidade \\
\hline Clientes & $\begin{array}{l}\text { Os dientes pertencem a diversas dasses } \\
\text { sociais }\end{array}$ & -1 & $\begin{array}{l}\text { Predominantemente segmentos da população que estão em } \\
\text { situaçāo de maior vulnerabilidade }\end{array}$ \\
\hline Fornecedores & $\begin{array}{l}\text { Os critérios para escolha são preço e } \\
\text { qualidade }\end{array}$ & 1 & $\begin{array}{l}\text { Procura-se contratar segmentos da população que estão em } \\
\text { situação de maior vulnerabilidade }\end{array}$ \\
\hline Colaboradores & Não há nenhuma prioridade na contratação & 1 & $\begin{array}{l}\text { Prioridade para segmentos da população que estão em situação } \\
\text { de maior vulnerabilidade }\end{array}$ \\
\hline Processo decisório & $\begin{array}{l}\text { Não há mecanismos institucionais para } \\
\text { participação coletiva }\end{array}$ & 1 & $\begin{array}{l}\text { Há mecanismos institucionais para participação coletiva } \\
\text { das comunidades com as quais o empreendimento atua }\end{array}$ \\
\hline Distribuiç̣̄o de loaro & Distribuiçāo de dividendos. & -1 & Lucro é totalmente investido \\
\hline Valor Econômico & $\begin{array}{l}\text { Todos os recursos são provenientes } \\
\text { de vendas de produtose servictos }\end{array}$ & 1 & $\begin{array}{l}\text { Depende de doaçōes e colaboraccôes institucionais para } \\
\text { desenvolver sua atividade principal }\end{array}$ \\
\hline Total & & 4 & \\
\hline
\end{tabular}


A inovação implementada pela Comaru é tipicamente organizacional, visto que possibilita o trabalho integrado de produtores com intenso compartilhamento de aprendizado, tornandose independentes da ação de intermediários. A abrangência da inovação é local e a sua profundidade caracterizada como incremental.

Em termos de geração de valor socioambiental, considera-se que os resultados diretos da Comaru são geração de renda a produtores locais (capital produtivo). Como comentou D. Elizabeth, moradora: "Alguns navios vinham do Pará trazendo vários produtos que eram trocados pela castanha. Trocava-se até mesmo uma 'saca' de castanha por uma lata de leite em pó". O aumento da renda está diretamente relacionado à eliminação de intermediários (diminuição de custos de transação). Outro benefício direto da ação da Comaru é o aumento do capital natural por estimular que os produtores obtenham renda a partir de produtos da floresta, estimulando a manutenção da "floresta em pé". Em termos indiretos, a Comaru possibilita o aumento do capital social pelo compartilhamento de informações entre produtores e aumento do capital humano pelo treinamento oferecido aos produtores para produção de óleo de castanha.

\subsection{4 - Cooperativa de Empreendimentos Solidários de Boa Vista - Coofec's (RR)}

A Cooperativa de Empreendimentos Solidários do Município de Boa Vista (Coofec's) foi fundada em 2009 no município de Boa Vista. É a única cooperativa de confecção do estado de Roraima (RR). Produz e comercializa uniformes (escolares e de empresas), ternos e vestidos sociais, vestidos para as festas juninas e ecobags.

Um dos diferenciais competitivos da Coofec's é sua flexibilidade em relação às quantidades de venda. Não há volume mínimo de pedido nem tamanho de lote padrão de produção. Essa flexibilidade é tida como um diferencial importante para os clientes da Coofec's - escolas e empresas (que fazem encomendas em maiores quantidades) e estudantes e grupos de dança (que compram peças únicas ou em pouca quantidade).

Em 2014, a organização contava com 20 costureiras que dividem igualmente entre si o resultado financeiro da cooperativa. Pelo fato de não terem sede própria, a cooperativa tem dificuldade de obter crédito para ampliar sua produção. O crescimento da organização é 
obtido a partir de recursos próprios. Como comentou a Maria dos Santos Souza, presidente da Coofec's na época do levantamento de dados: "Quando o governo parou de comprar das associações, fundamos a cooperativa para poder vender nossos produtos. Mas no começo não tínhamos nem matéria-prima. Conseguíamos fazer dez camisetas. Com o dinheiro da venda, compramos material e fizemos um pouco mais. Assim fomos crescendo".

Por ser uma cooperativa fundada a partir dos princípios da Economia Solidária, a Comaru foi classificada como um empreendimento social com uma lógica de atuação com ênfase no social, obtendo uma pontuação de 4 (de um total que varia de -10 a 10), conforme apresentado na tabela 27, a seguir:

Tabela 27 - Posicionamento do Empreendimento Social - Coofec's

\begin{tabular}{|c|c|c|c|}
\hline Fotores & Lógica de Mercodo & $\begin{array}{l}\text { Coofec's } \\
\text { (RR) }\end{array}$ & Lógica Socid \\
\hline Objefivo prinaipal & Aproveitar uma oportunidade de mercado & 1 & Resolver um problema socioambiental \\
\hline Oferta & $\begin{array}{l}\text { Bens e servicos voltados para o consumo } \\
\text { da população }\end{array}$ & -1 & $\begin{array}{l}\text { Bens e serviços voltados para necessidades básicas e/ou } \\
\text { que conservem a biodiversidade }\end{array}$ \\
\hline Intencionalidade & $\begin{array}{l}\text { Geraccão de valor social é um componente } \\
\text { importante, porém não central }\end{array}$ & 1 & Geração de valor social é o core business do negócio \\
\hline Escala & Fator relevante & 1 & Replicabilidade é mais relevante que a escalabilidade \\
\hline Clientes & $\begin{array}{l}\text { Os dientes pertencem a diversas dasses } \\
\text { sociais }\end{array}$ & -1 & $\begin{array}{l}\text { Predominantemente segmentos da população que estão em } \\
\text { situaçāo de maior vulnerabilidade }\end{array}$ \\
\hline Fornecedores & $\begin{array}{l}\text { Os critérios para escolha são preço e } \\
\text { qualidade }\end{array}$ & 1 & $\begin{array}{l}\text { Procura-se contratar segmentos da população que estão em } \\
\text { situação de maior vulnerabilidade }\end{array}$ \\
\hline Colaboradores & Não há nenhuma prioridade na contrataçāo & 1 & $\begin{array}{l}\text { Prioridade para segmentos da população que estão em situação } \\
\text { de maior vulnerabilidade }\end{array}$ \\
\hline Processo decisório & $\begin{array}{l}\text { Não há mecanismos institucionais para } \\
\text { participacẫo coletiva }\end{array}$ & 1 & $\begin{array}{l}\text { Há mecanismos institucionais para participacão coletiva } \\
\text { das comunidades com as quais o empreendimento atua }\end{array}$ \\
\hline Distribuiç̣̄o de luaro & Distribuição de dividendos. & -1 & Lucro é totalmente investido \\
\hline Valor Econômico & $\begin{array}{l}\text { Todos os recursos são provenientes } \\
\text { de vendas de produtose serviços }\end{array}$ & 1 & $\begin{array}{l}\text { Depende de doaçōes e colaboraçōes institucionais para } \\
\text { desenvolver sua atividade principal }\end{array}$ \\
\hline Total & & 4 & \\
\hline
\end{tabular}

Fonte: elaborada pela autora

A inovação implementada pela Coofec's na localidade é tipicamente organizacional, visto que possibilita o trabalho integrado de mulheres que trabalhavam de forma isolada ficando expostas à ação de intermediários para comercialização de seus produtos. A abrangência da inovação é local e sua profundidade caracterizada como incremental.

Em termos de geração de valor socioambiental, considera-se que o benefício direto da Coofec's é o estimula à geração de renda dos produtores locais (capital produtivo). 0 aumento da renda está diretamente relacionado à eliminação de intermediários (diminuição de custos de transação). Em termos indiretos, a Coofec's possibilita o aumento do capital 
social pelo compartilhamento de informações entre as costureiras, aumento de sua autoestima e reconhecimento de sua profissionalização (aumento de capital humano).

\subsection{5 - Descarte Correto (AM)}

A Descarte Correto foi fundada, em 2010, a partir da sanção da Política Nacional de Resíduos Sólidos, que tem como objetivo instruir e tornar obrigatória a destinação correta dos resíduos eletroeletrônicos no Brasil. Segundo a Lei no 12.305, de 2 de agosto de 2010, devem ser estruturados e implementados sistemas de logística reversa que viabilizem o retorno de certos tipos de resíduos sólidos ao setor responsável por sua produção/distribuição para a destinação correta. No entanto, o início do empreendimento data de 2001, quando os irmãos André e Alessandro Dinelli inauguraram o Centro de Inclusão Digital da Amazônia em Maués para capacitar jovens em informática.

O centro formou cerca de 90 pessoas somente na primeira turma. Posteriormente, vários outros foram criados a partir de doações de equipamentos obsoletos de empresas. Em 2004, a organização da sociedade civil Comitê para a Democratização da Informática da Amazônia (CDI Amazônia) foi oficialmente constituída. Em 2009, já existiam 15 CDIs em diferentes regiões do país e mais de 15 mil pessoas haviam sido capacitadas em seus programas de treinamento.

Apesar do importante trabalho realizado, os centros, em sua maioria, não eram financeiramente sustentáveis. As taxas cobradas dos alunos - $R \$ 15,00$ - destinadas à manutenção dos centros, não eram suficientes. Além disso, a OS estava acumulando um passivo ambiental e necessitava dar o destino correto a esse lixo. Assim, a criação da empresa Descarte Correto objetivou enfrentar estes desafios e garantir a sustentabilidade financeira do negócio.

A empresa recebe todos os equipamentos tecnológicos de seus clientes - órgãos do governo, empresas privadas e usuários -, tanto em funcionamento quanto com defeito. São computadores, notebooks, celulares, estabilizadores, mouses, monitores, teclados e outros similares. Ao recebê-los, estes são desmontados, descaracterizados, recondicionados e adaptados. Posteriormente, são realizadas as etapas de montagem, instalação de software, 
limpeza e embalagem. Os computadores remontados são encaminhados para os centros de inclusão digital em regime de comodato e os resíduos são destinados a empresas parceiras de reciclagem.

O material é coletado dos órgãos de governo e empresas privadas por meio de caminhões contratados pelo próprio Descarte Correto, em Manaus. Além disso, são utilizados pontos de coleta espalhados pela cidade para coletar o lixo eletrônico da população de maneira geral. Ao descartar o lixo eletrônico nestes pontos, as pessoas ganham descontos para comprar novos equipamentos em uma loja parceira - a Amazon Print. Apesar do volume recolhido por estes pontos ser pequeno, representando $5 \%$ de todo material recolhido, eles funcionam como um importante instrumento de conscientização e educação ambiental para a população.

O Descarte Correto tem duas principais fontes de renda: venda dos resíduos para empresas de reciclagem e uma taxa recebida pela gestão de resíduos eletrônicos e emissão de certificado de descarte correto da empresa contratante. Para alguns poucos materiais, como o monitor CRT, é cobrada uma taxa para o recebimento do material. Até o momento, $100 \%$ do lucro foi reinvestido no próprio negócio. No entanto, de acordo com o contrato social, até $70 \%$ dos lucros podem ser distribuídos entre os sócios e 30\% deve ser reinvestido.

A empresa oferece também um programa de capacitação de jovens para profissionalizá-los como auxiliares técnicos em manutenção de computadores e redes. Alguns desses jovens são contratados pela própria empresa no processo de desmontagem e recondicionamento do material recebido.

Os dados levantados permitem classificar a Descarte Correto como um empreendimento social com uma lógica de mercado em função de sua área de atuação, obtendo uma pontuação de -4 (de um total que varia de -10 a 10), conforme apresentado na tabela 28. 
Tabela 28 - Posicionamento do Empreendimento Social - Descarte Correto

\begin{tabular}{|c|c|c|c|}
\hline Fotores & Lógica de Wercodo & $\begin{array}{l}\text { Descarte Correto } \\
\text { (AM) }\end{array}$ & Lógica Socid \\
\hline Objetivo principal & Aproveitar uma oportunidade de mercado & -1 & Resolver um problema socioambiental \\
\hline Oferta & $\begin{array}{l}\text { Bens e serviços voltados para o consumo } \\
\text { da população }\end{array}$ & -1 & $\begin{array}{l}\text { Bens e servicos voltados para necessidades básicas e/ou } \\
\text { que conservem a biodiversidade }\end{array}$ \\
\hline Intencionalidade & $\begin{array}{l}\text { Geraçāo de valor social é um componente } \\
\text { importante, porém nōo central }\end{array}$ & 1 & Geração de valor social é o core business do negócio \\
\hline Escala & Fator relevante & -1 & Replicabilidade é mais relevante que a escalabilidade \\
\hline Clientes & $\begin{array}{l}\text { Os clientes pertencem a diversas classes } \\
\text { sociais }\end{array}$ & 1 & $\begin{array}{l}\text { Predominantemente segmentos da população que estão em } \\
\text { situação de maior vulnerabilidade }\end{array}$ \\
\hline Fornecedores & $\begin{array}{l}\text { Os critérios para escolha são preço e } \\
\text { qualidade }\end{array}$ & -1 & $\begin{array}{l}\text { Procura-se contratar segmentos da população que estão em } \\
\text { situação de maior vulnerabilidade }\end{array}$ \\
\hline Colaboradores & Não há nenhuma prioridade na contrataçāo & 1 & $\begin{array}{l}\text { Prioridade para segmentos da população que estão em situação } \\
\text { de maior vulnerabilidade }\end{array}$ \\
\hline Processo decisório & $\begin{array}{l}\text { Não há mecanismos institucionais para } \\
\text { participaçāo coletiva }\end{array}$ & -1 & $\begin{array}{l}\text { Há mecanismos institucionais para participação coletiva } \\
\text { das comunidades com as quais o empreendimento atua }\end{array}$ \\
\hline Distribuiç̣̄o de luaro & Distribuiçāo de dividendos. & -1 & Lucro é totalmente investido \\
\hline Valor Econômico & $\begin{array}{l}\text { Todos os recursos são provenientes } \\
\text { de vendas de produtose servictos }\end{array}$ & -1 & $\begin{array}{l}\text { Depende de doações e colaboraçōes institucionais para } \\
\text { desenvolver sua atividade prinçipal }\end{array}$ \\
\hline Tofal & & -4 & \\
\hline
\end{tabular}

Fonte: elaborada pela autora

A principal inovação implementada pela empresa Descarte Correto é organizacional, considerando as parcerias que foram estabelecidas para viabilizar a coleta e destinação correta dos materiais eletrônicos, bem como por estabelecer parcerias para estimular o descarte correto por meio de descontos na compra de produtos. A abrangência da inovação é local e sua profundidade caracterizada como incremental.

Em termos de geração de valor socioambiental, considera-se que as contribuições diretas da Descarte Correto sejam: reciclagem de lixo eletrônico (reuso de materiais), bem como o estimula à empregabilidade de jovens de baixa renda (capital humano), visto que oferece capacitação em manutenção de computadores e redes. Como contribuição indireta, destacam-se o aumento da consciência ambiental e a geração de renda pela contratação de alguns jovens capacitados pela própria empresa (capital produtivo). A doação dos computadores remontados para centros de inclusão digital permite, ainda, que pessoas sem acesso a um computador aprendam a utilizá-lo adequadamente. A inclusão digital vai muito além do uso de redes sociais e troca de e-mails, pois permite ao usuário utilizar este meio para fortalecer suas potencialidades, aprender sobre novos temas e melhorar suas condições de vida (cidadania). 


\subsection{6 - Associação de Certificação Socioparticipativa - ACS (AC)}

A Associação de Certificação Socioparticipativa da Amazônia (ACS Amazônia) é uma organização da sociedade civil criada, em 2003, em Rio Branco, com a finalidade de tornar acessível a obtenção da certificação socioambiental e orgânica para as comunidades que vivem na Floresta Amazônica. "A ACS busca estabelecer diálogo entre os conhecimentos técnico e tradicional, de campesino para campesino, através de métodos participativos que privilegiam a educação, a participação, a confiança, a corresponsabilidade e a transparência no processo", declara Ermelindo Ribeiro, 49 anos, coordenador executivo da ACS Amazônia, em 2013. Em 2013, 51 famílias de agricultores estavam vinculadas a ACS, distribuídas em cinco grupos: Polo Benfica, Polo Wilson Pinheiro, Humaitá, Moreno Maia e Reca (AC).

Todos os envolvidos no processo são responsáveis por garantir a conformidade dos produtos e processos dos grupos. Tal sistema não se enquadra na comercialização em mercados distantes, porém é apropriada para mercados locais na medida em que garante o contato dos consumidores com os agricultores.

Além de garantir a qualidade dos produtos, a ACS busca fortalecer a comercialização dos alimentos por meio da participação dos grupos na "Feira Orgânica" de Rio Branco o que gerou um aumento de $400 \%$ na renda das famílias de acordo com Ermelindo.

Os dados levantados permitem classificar a ACS como um empreendimento social com atuação ainda muito típica das organizações da sociedade civil o que reflete em uma pontuação máxima de 10 de um continuum que varia de -10 a 10 . Vide tabela abaixo 29, a seguir. 
Tabela 29 - Posicionamento do Empreendimento Social - ACS

\begin{tabular}{|c|c|c|c|}
\hline Fatores & Lógica de Mercodo & $\begin{array}{l}\text { ACS } \\
\text { (AC) }\end{array}$ & Lógica Socid \\
\hline Objefivo prinaipal & Aproveitar uma oportunidade de mercado & 1 & Resolver um problema socioambiental \\
\hline Oferta & $\begin{array}{l}\text { Bens e servicos voltados para o consumo } \\
\text { da população }\end{array}$ & 1 & $\begin{array}{l}\text { Bens e serviços voltados para necessidades básicas e/ou } \\
\text { que conservem a biodiversidade }\end{array}$ \\
\hline Intencionalidade & $\begin{array}{l}\text { Geração de valor social é um componente } \\
\text { importante, porém nõo central }\end{array}$ & 1 & Geração de valor social é o core business do negócio \\
\hline Escala & Fator relevante & 1 & Replicabilidade é mais relevante que a escalabilidade \\
\hline Clientes & $\begin{array}{l}\text { Os dientes pertencem a diversas classes } \\
\text { sociais }\end{array}$ & 1 & $\begin{array}{l}\text { Predominantemente segmentos da populaçāo que estão em } \\
\text { situação de maior vulnerabilidade }\end{array}$ \\
\hline Fornecedores & $\begin{array}{l}\text { Os critérios para escolha são preço e } \\
\text { qualidade }\end{array}$ & 1 & $\begin{array}{l}\text { Procura-se contratar segmentos da população que estão em } \\
\text { situação de maior vulnerabilidade }\end{array}$ \\
\hline Colaboradores & Não há nenhuma prioridade na contrataçāo & 1 & $\begin{array}{l}\text { Prioridade para segmentos da população que estão em situação } \\
\text { de maior vulnerabilidade }\end{array}$ \\
\hline Processo decisório & $\begin{array}{l}\text { Não há mecanismos institucionais para } \\
\text { participação coletiva }\end{array}$ & 1 & $\begin{array}{l}\text { Há mecanismos institucionais para participação coletiva } \\
\text { das comunidades com as quais o empreendimento atua }\end{array}$ \\
\hline Distribuiç̣öo de luao & Distribuiçāo de dividendos. & 1 & Lucro é totalmente investido \\
\hline Valor Econômico & $\begin{array}{l}\text { Todos os recursos são provenientes } \\
\text { de vendas de produtose servictos }\end{array}$ & 1 & $\begin{array}{l}\text { Depende de doaçôes e colaboraccôes institucionais para } \\
\text { desenvolver sua atividade principal }\end{array}$ \\
\hline Tofal & & 10 & \\
\hline
\end{tabular}

Fonte: elaborada pela autora

O grande desafio da ACS é a reformulação do seu modelo de negócios de modo a garantir a regularidade de uma receita advinda de sua operação. Na época do levantamento de dados, em 2013, a organização dependia de recursos obtidos por meio de editais abertos por instituições públicas e privadas.

A inovação implementada pela ACS Amazônia é tipicamente organizacional, pois possibilitou o compartilhamento de aprendizado entre os produtores e mobilizou-os para a ação coletiva. A abrangência da inovação é local e a sua profundidade caracterizada como incremental.

Em termos de geração de valor socioambiental, considera-se que os benefícios diretos da ACS são: geração de renda a produtores locais (capital produtivo), eliminação de intermediários (diminuição de custos de transação). De forma indireta, a ACS possibilita o aumento de serviços ecossistêmicos pela orientação do plantio (capital natural), aumento do conhecimento técnico dos produtores (capital humano), aumento do capital social e cidadania, como ressaltou Ermelindo e de Andreson Silva de Assis, 35, colaborador técnico voluntário : "É a satisfação de ver o produtor como um ser social, inserido em uma comunidade, em contato com o consumidor, dizendo com orgulho 'eu sou produtor orgânico'”. 


\subsection{7 - Amata (RO)}

A Amata, fundada em 2005 por Dario Guarita Neto, Roberto Waack e Etel Carmona, é uma empresa que objetiva a gestão sustentável de floresta, atuando na geração de valor econômico por meio de todos os bens que podem ser produzidos, de maneira sustentável. Tem como produtos: madeira certificada, produtos não madeireiros e serviços ambientais. Posiciona-se nas três vertentes do setor florestal, com maior concentração no setor madeireiro, em função das próprias características de produção de áreas florestais. Atua tanto com serrada bruta e madeira para os setores moveleiros e construção civil, quanto madeira para processo, a ser utilizado nos setores de energia e de celulose e papel.

A madeira produzida pela Amata é proveniente tanto de florestas plantadas - de espécies nativas, eucalipto e pinos - como também do manejo de baixo impacto em florestas nativas. A empresa acredita que um de seus ativos é a capacidade de trabalhar com os diversos tipos de floresta - o chamado contínuo florestal. Foi a primeira empresa a conseguir uma concessão governamental, em Rondônia, para executar o manejo sustentável de florestas públicas no Brasil.

A operação da empresa propriamente dita começou em 2008, iniciando sua operação em diferentes estados do país: Pará (2008); Rondônia (2008); Mato Grosso do Sul (2012); Paraná (2013). No total, gestiona mais de 119 mil hectares de floresta, nas regiões Norte, Centrooeste e Sul do país. O produto da Amata chegou ao mercado em 2011, com a primeira venda de madeira serrada, concluindo-se aí o primeiro ciclo do manejo de baixo impacto na floresta do Jamari, Rondônia (RO). Sua operação está diversificada entre florestas de espécies nativas e exóticas, plantadas e naturais, terceiras e próprias ${ }^{11}$. O Manejo Florestal Sustentável é premissa em todas quatro regiões operacionais, tanto em áreas próprias quanto de propriedade de terceiros. São utilizadas técnicas que minimizam o impacto das atividades e garantem a equivalência entre as taxas de colheita e de regeneração florestal,

\footnotetext{
${ }^{11}$ A AMATA maneja cerca de 50 espécies de árvores nativas e exóticas. Entre elas estão: Eucalipto, Pinus, Paricá, Açaí, Acapu, Andiroba, Ingá, Ipê-amarelo, Jucá, Mamorana, Jatobá, Jacarandá, Pupunha, Paineira, Seringueira, Tambori e Urucum. No seu website, a empresa disponibiliza uma Xiloteca, isto é, um banco de dados sobre todas as espécies disponíveis, origem da colheita, suas características e indicações de aplicação conforme os produtos comercializados. Entre as nativas, o Paricá é o produto principal, representando mais de $90 \%$ da extração realizada.
} 
mantendo a sustentabilidade da produção. Todas as áreas são certificadas pelo Forest Stewardship Council (FSC).

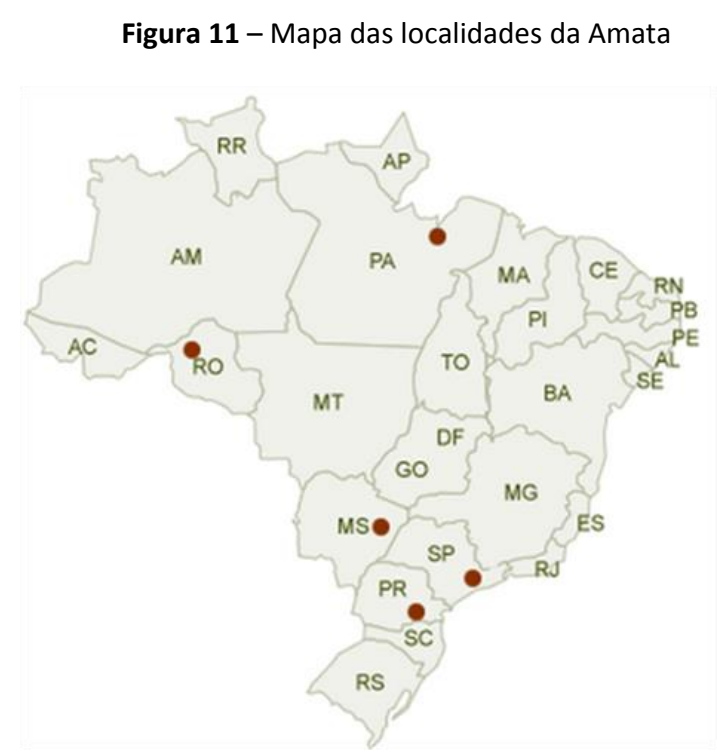

Pará (PA): Castanhal, Paragominas e Ipixuna Plantio de nativas em áreas degradadas. A Amata é responsável pela gestão e operação de áreas próprias e arrendadas.

Rondônia (RO): Floresta Nacional do Jamari Manejo de Nativas e Indústria, por meio de concessão da Unidade de Manejo Florestal 3 da Floresta Nacional do Jamari

Mato Grosso do Sul (MS): Três Lagoas Plantio de Eucalipto e Pinus, operação greenfield de plantações em áreas tradicionais de uso pecuário.

Paraná (PR): Aquisição de florestas existentes de pinus e eucalipto em Rio Branco do Sul, Itaperuçu, Cerro Azul, Campo Largo, Castro, Palmeira e Ponta Grossa.

São Paulo (SP): Escritório corporativo.

Fonte: website Amata

Em todas as localidades, há o agente socioambiental, responsável por trabalhar a relação da empresa com a comunidade e os funcionários. O objetivo é estabelecer uma relação de troca e empatia com os envolvidos. Não há, no registro das operações da Amata, histórico de conflitos significativos com as comunidades locais.

Os dados levantados permitem classificar a Amata como um empreendimento que tem bastante preocupação com o mercado, porém busca uma atuação que gere também valor socioambiental para região o que reflete em uma pontuação - 6 de um continuum que varia de -10 a 10, conforme apresentado na tabela 30. 
Tabela 30 - Posicionamento do Empreendimento Social - Amata

\begin{tabular}{|c|c|c|c|}
\hline Fotores & Lógica de Mercodo & $\begin{array}{c}\text { Amata } \\
\text { (RO) }\end{array}$ & Lógica Socid \\
\hline Objetivo principal & Aproveitar uma oportunidade de mercado & -1 & Resolver um problema socioambiental \\
\hline Oferta & $\begin{array}{l}\text { Bens e serviços voltados para o consumo } \\
\text { da populaçăo }\end{array}$ & 1 & $\begin{array}{l}\text { Bens e serviços voltados para necessidades básicas e/ou } \\
\text { que conservem a biodiversidade }\end{array}$ \\
\hline Intencionalidade & $\begin{array}{l}\text { Geração de valor social é um componente } \\
\text { importante, porém não central }\end{array}$ & -1 & Geração de valor social é o core business do negócio \\
\hline Escala & Fator relevante & -1 & Replicabilidade é mais relevante que a escalabilidade \\
\hline Clientes & $\begin{array}{l}\text { Os clientes pertencem a diversas dasses } \\
\text { sociais }\end{array}$ & -1 & $\begin{array}{l}\text { Predominantemente segmentos da população que estão em } \\
\text { situação de maior vulnerabilidade }\end{array}$ \\
\hline Fornecedores & $\begin{array}{l}\text { Os critérios para escolha são preço e } \\
\text { qualidade }\end{array}$ & -1 & $\begin{array}{l}\text { Procura-se contratar segmentos da população que estão em } \\
\text { situacạōo de maior vulnerabilidade }\end{array}$ \\
\hline Colaboradores & Não há nenhuma prioridade na contratação & -1 & $\begin{array}{l}\text { Prioridade para segmentos da população que estão em situação } \\
\text { de maior vulnerabilidade }\end{array}$ \\
\hline Processo decisório & $\begin{array}{l}\text { Não há mecanismos institucionais para } \\
\text { participação coletiva }\end{array}$ & 1 & $\begin{array}{l}\text { Há mecanismos institucionais para participaçāo coletiva } \\
\text { das comunidades com as quais o empreendimento atua }\end{array}$ \\
\hline Distribuiç̣̄o de loaro & Distribuição de dividendos. & -1 & Lucro é totalmente investido \\
\hline Valor Econômico & $\begin{array}{l}\text { Todos os recursos são provenientes } \\
\text { de vendas de produtose servictos }\end{array}$ & -1 & $\begin{array}{l}\text { Depende de doações e colaboraccōes institucionais para } \\
\text { desenvolver sua atividade principal }\end{array}$ \\
\hline Total & & -6 & \\
\hline
\end{tabular}

Fonte: elaborada pela autora

A principal inovação da Amata pode ser categorizada como processo: o desenvolvimento de conhecimento sobre a plantação e o manejo de florestas nativas tornou-se um dos ativos intangíveis da Amata, especialmente do Paricá, carro-chefe de sua produção de espécies nativas. Outra inovação da empresa refere-se ao seu modelo de negócios (organizacional): desenvolveu capacidade para a gestão de concessão florestal e desenvolveu um modelo de relacionamento socioambiental com as comunidades no entorno de sua operação. Além disso, é uma das poucas, se não a única empresa, a atuar em ambos ambientes florestais nativas e plantadas. Foi a primeira empresa obter concessão pública da gestão de floresta, tendo a preocupação de articular-se com a comunidade local e agentes públicos. A abrangência da inovação é nacional sendo a sua profundidade caracterizada como institucional visto que reconfigura a forma de atuação da indústria de madeira.

Em termos de geração de valor socioambiental, considera-se que a maior contribuição direta da Amata é o aumento da oferta de capital natural. Como contribuições indiretas, destacamse: o estimulo à consciência ambiental do mercado consumidor de madeira e o incremento da geração de renda para as comunidades locais. 


\section{5 - Resultados e Discussão}

Todos os negócios sociais mapeados na pesquisa Brasil27 podem ser considerados híbridos nos seus modelos organizacionais uma vez que a geração de valor socioambiental e resultado financeiro fazem parte de sua missão (BATTILANA et al., 2012). No entanto, o grau de hibridismo não é homogêneo (ALTER, 2007).

A régua elaborada neste estudo ajudou a classificar os negócios sociais existentes no Brasil e evidenciou a diversidade deste tipo de empreendimento. No Brasil, observa-se uma heterogeneidade de formatos, conforme apontado no referencial teórico, não havendo uma predominância de um tipo em relação aos demais. A figura 12 mostra que a distribuição dos casos analisados foi bem uniforme, ou seja, há 13 casos que atuam com uma lógica muito similar a uma empresa tradicional, pois orientam sua ação com maior preocupação na competitividade. Outros 14 empreendimentos pautam sua atuação de forma muito similar a uma organização da sociedade civil, nos quais a consecução de objetivos sociais é central na ação e na tomada de decisão dos gestores dos empreendimentos.

Figura 12 - Classificação dos Casos Analisados

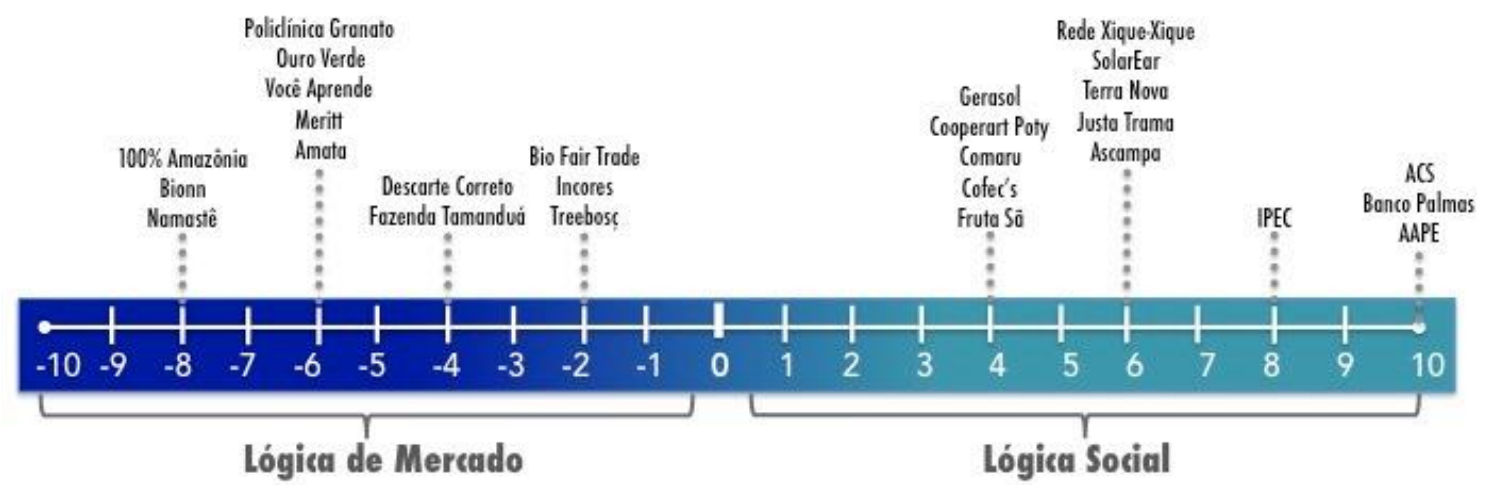

Fonte: elaborada pela autora

Os fatores que mais diferenciaram os empreendimentos analisados foram os itens de governança e cadeia de valor, ou seja, os empreendimentos com maior ênfase social tendem a criar instâncias de participação das comunidades nas quais atua. Além disso, buscam também contratar colaboradores e fornecedores de segmentos da população em situação de maior vulnerabilidade socioeconômica. 
Por outro lado, é interessante notar uma possível tendência de atuação dos empreendimentos com maior orientação ao mercado na oferta de produtos com maior valor agregado, direcionados ao consumidor preocupado com questões de sustentabilidade e bem-estar. Por exemplo, no consumo de orgânicos, derivados de produtos da Amazônia, madeira certificada, itens únicos e artesanais, entre outros.

Observou-se, ainda, que há uma tendência de negócios sociais estruturados no formato jurídico de cooperativas e associações atuarem com uma lógica mais voltada a objetivos e resultados sociais. No entanto, isto não é mandatório: casos como Solar Ear e Terra Nova são exemplos de empreendimentos que tem uma preocupação central com geração de valor socioambiental, embora juridicamente estejam formatados como empresas de constituição limitada. No caso de empreendimentos solidários, pode-se dizer que todos eles se pautam por valores de solidariedade, participação coletiva, confiança e geração de renda para segmentos com maior vulnerabilidade, a maioria destes alinhados aos princípios da chamada Economia Solidária. Dessa forma, sua lógica de atuação tem maior ênfase no social com uma preocupação de crescimento por meio da replicabilidade do modelo.

Observando a distribuição geográfica dos casos, não é possível fazer nenhum tipo de inferência sobre a predominância de um modelo em uma determinada região, como mostra a Figura 13.

Figura 13 - Distribuição Geográfica dos Casos Analisados

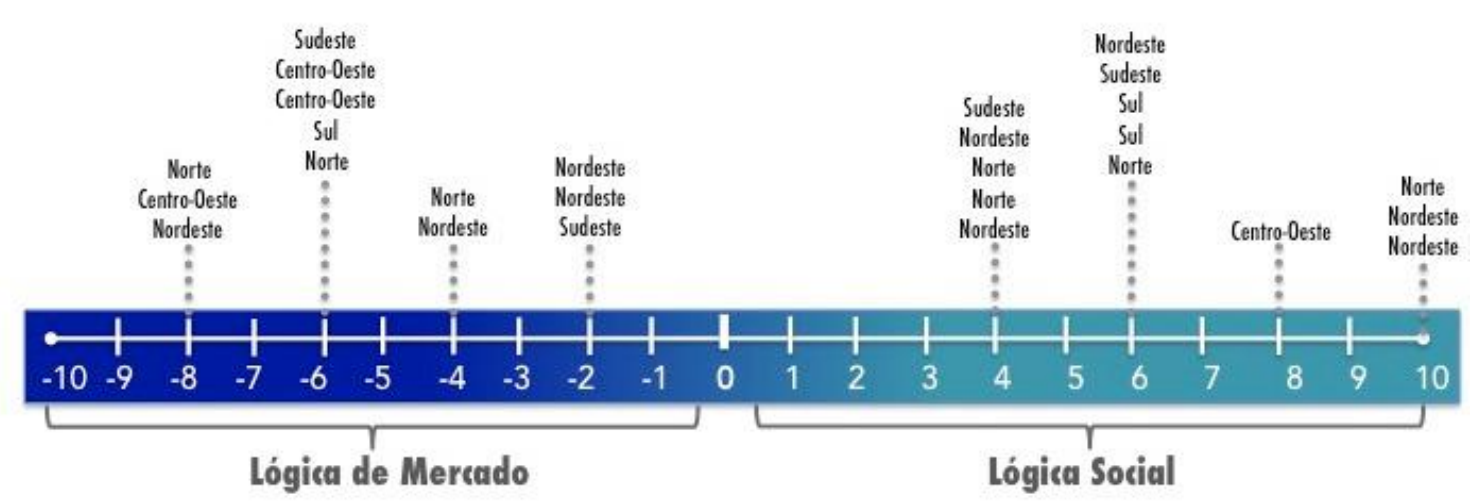

Fonte: elaborada pela autora 
A classificação dos casos, como mostra a Figura 14, permitiu observar a diversificação de modelos de negócios sociais. Há uma tendência positiva entre o posicionamento do empreendimento e a geração de valor socioambiental: os empreendimentos com maior orientação social (lógica social) geram mais resultados diretos e indiretos em termos de valor socioambiental. Para calcular os valores, foi atribuído valor 2 a um efeito direto e 1 para efeito indireto em cada dos oito fatores estabelecidos (capital físico, capital produtivo, capital natural, economia de baixo carbono, capital humano, custos de transação, reuso de materiais, capital social e cidadania), de acordo com a missão e objetivos da organização. É importante ressaltar que esta análise tem como princípio traduzir a intencionalidade do empreendimento e não mensurar o seu impacto.

Os empreendimentos sociais que atuam com uma lógica de mercado representam um grupo mais heterogêneo, observando-se uma variação maior nas categorias de geração de valor socioambiental. Os empreendimentos sociais com uma maior orientação para o social tendem a privilegiar a geração de valor socioambiental nas categorias capital humano e capital produtivo, desenhando seu modelo de negócio de tal forma a proporcionar também valor nas dimensões de capital social e cidadania.

Figura 14 - Geração de Valor Socioambiental dos Casos Analisados

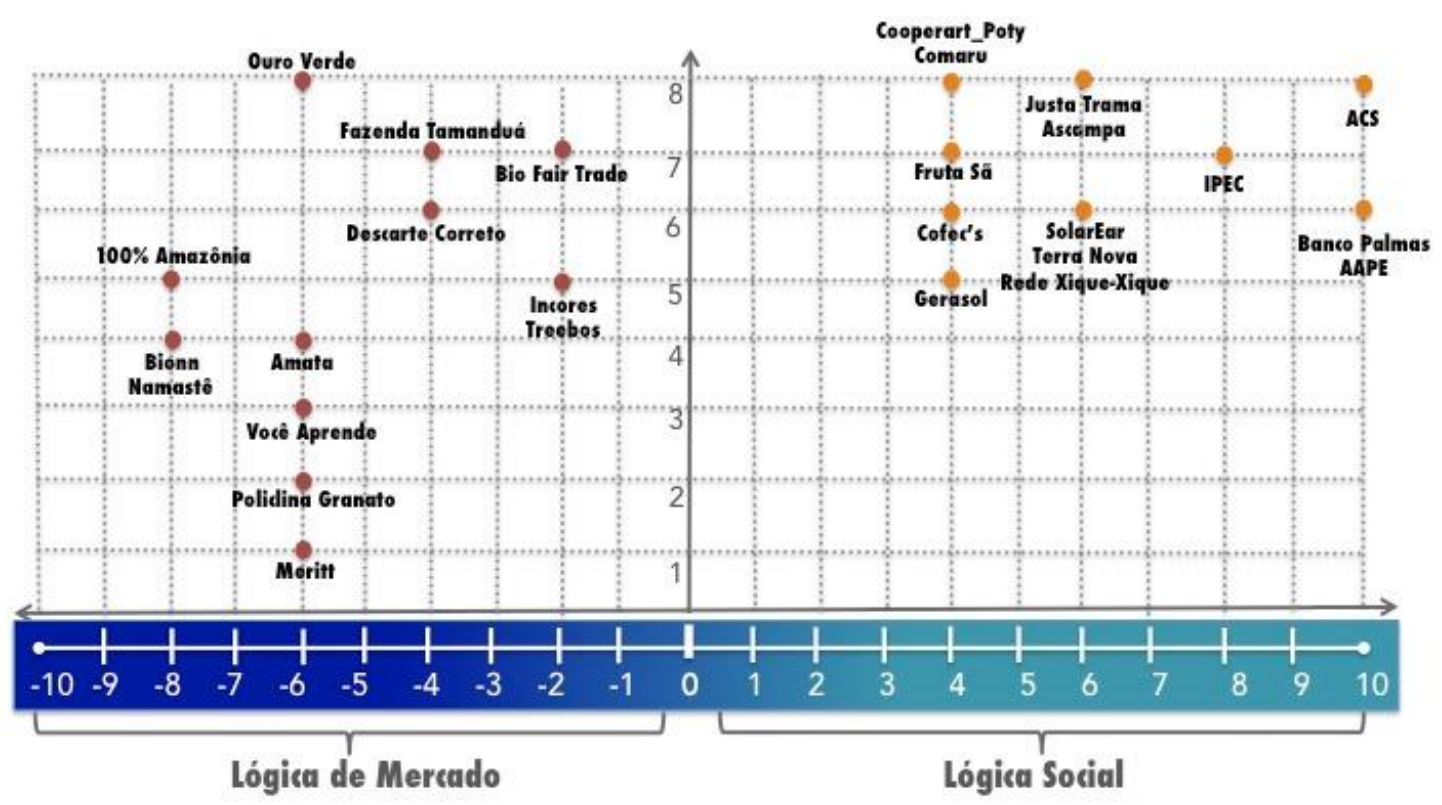

Fonte: elaborada pela autora 
A tabela 31 apresenta os dados agregados dos casos. Em termos gerais, observou-se que os negócios sociais analisados enfatizam, prioritariamente, a geração de renda (capital produtivo), profissionalização, acesso aos serviços de saúde e oferta de produtos saudáveis (capital humano). Os dados do levantamento apontam que há, ainda, um amplo espaço para criação de empreendimentos sociais com maior preocupação ambiental: menos da metade dos casos (10) desenvolvem atividades que visam a conservação da biodiversidade e somente quatro contribuem para uma economia de baixo carbono.

Tabela 31 - Categorias de Geração de Valor Socioambiental

\begin{tabular}{|l|c|c|}
\hline Geração de Valor Socioambiental - Dados Agregados & Qt Neg.Sociais & $\%$ \\
\hline Capital Produtivo & 21 & $78 \%$ \\
\hline Capital Humano & 19 & $70 \%$ \\
\hline Cidadania/Autoestima & 16 & $59 \%$ \\
\hline Custos de Transação & 15 & $56 \%$ \\
\hline Capital Social & 15 & $56 \%$ \\
\hline Capital Natural & 10 & $37 \%$ \\
\hline Reaproveitamento de Materiais & 4 & $15 \%$ \\
\hline Economia de Baixo Carbono & 4 & $15 \%$ \\
\hline Capital Físico & 1 & $4 \%$ \\
\hline
\end{tabular}

Fonte: elaborada pela autora

O tipo de inovação mais observado nos negócios sociais é organizacional, definida, segundo o Manual de Oslo (OECD, 2005), como: novo método organizacional nas práticas de negócios da empresa (novos métodos para organização de rotina e procedimentos para condução do trabalho), na organização do seu local de trabalho (novas formas de distribuição de responsabilidades e poder de decisão), ou em suas relações externas (novos meios de colaboração e parcerias). A maior parte dos empreendimentos sociais (17) inovou a partir de uma estratégia voltada para construção de parcerias e alianças. Poucos empreendimentos sociais (apenas sete) desenvolveram novos métodos de produção ou logística com foco na redução de custos (inovação de processo). A ênfase dos negócios sociais tem sido no aproveitamento de oportunidades de mercado, por meio da introdução de novos produtos ou de diferentes canais de venda. A tabela 32 sintetiza os resultados. 
Tabela 32 - Categorias de Inovação

\begin{tabular}{|l|c|}
\hline Tipos de Inovação & Qt Neg Sociais \\
\hline Organizacional & 17 \\
\hline Mercado & 12 \\
\hline Produto/Serviço & 11 \\
\hline Processo & 7 \\
\hline \multicolumn{2}{|c|}{ Fonte: elaborada pela autora }
\end{tabular}

Como pode ser observado na figura 15, há uma tendência dos negócios sociais introduzirem inovações pontuais: 14 empreendimentos desenvolveram apenas um tipo de inovação. A inovação de processo não recebeu muita atenção dos empreendimentos sociais analisados. Apenas um caso (Fazenda Tamanduá) introduziu um novo produto (spirulina) e simultaneamente modificou o processo produtivo de forma a economizar recursos naturais como água.

A maioria dos negócios sociais associou um tipo de inovação, seja de mercado seja de produto, a uma modificação em seu modelo de negócio. Isto poderia significar que o empreendimento social aproveita ao máximo a troca de experiências e conhecimento entre parceiros para viabilizar uma inovação. Este fato parece ser o grande diferencial dos negócios sociais em relação a empresas tradicionais que tem maior dificuldade de estabelecer parcerias com outros atores para estruturação de produtos/serviços inovadores, com receio de perder diferencial competitivo. Com atitude oposta, os empreendimentos sociais defendem a inovação aberta e colaborativa.

A figura 15 também sinaliza uma tendência dos negócios sociais: habilidade em aproveitar lacunas no mercado, provavelmente em função de falhas de atuação do Estado ou desinteresse de grandes corporações ( $50 \%$ dos empreendimentos sociais implementaram uma inovação mercadológica que envolve venda de um produto ou serviço com preços ou canais diferenciados). 
Figura 15 - Tipo de Inovação implementada nos Casos Analisados

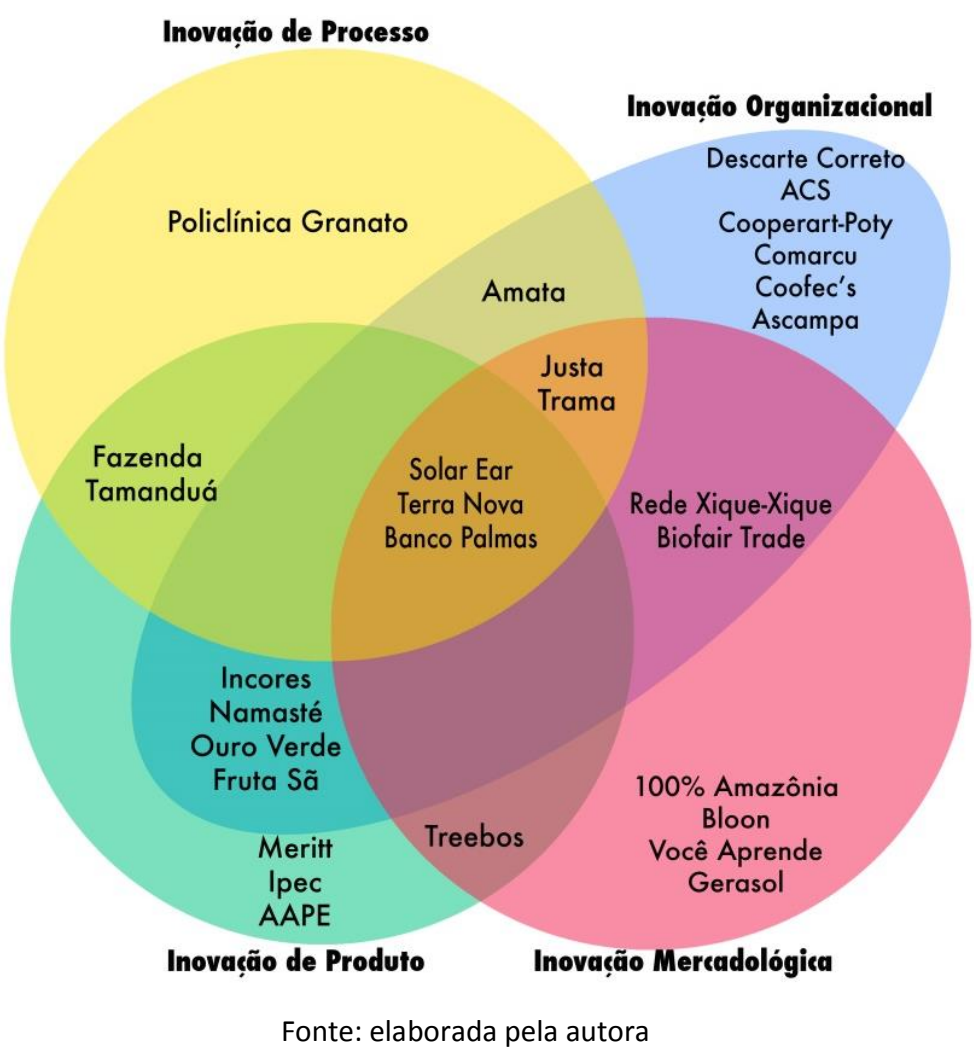

No levantamento realizado, apenas três empreendimentos sociais (Terra Nova, Banco Palmas e Solar Ear) podem ser consideradas organizações fortemente inovadoras, ao implementar aprimoramentos significativos nas quatro categorias (produto, processo, mercado e organizacional).

Ao analisar a relação entre lógica de atuação dos negócios sociais e os tipos de inovação, os dados apontam uma relação positiva entre inovação organizacional e empreendimentos cuja orientação social é predominante. Isto significa que negócios sociais com lógica social tendem a valorizar o estabelecimento de parcerias entre organizações e estimulam o compartilhamento de saberes entre os atores. Em negócios sociais com lógica de mercado, observou-se maior tendência de inovações de produto e mercadológica, alinhadas com uma estratégia de aproveitamento de oportunidades de nicho de mercado e consumo, como pode ser observado na figura 16. 
Figura 16 - Tipo de Inovação e Posicionamento dos Negócios Sociais

Inovação de Produto

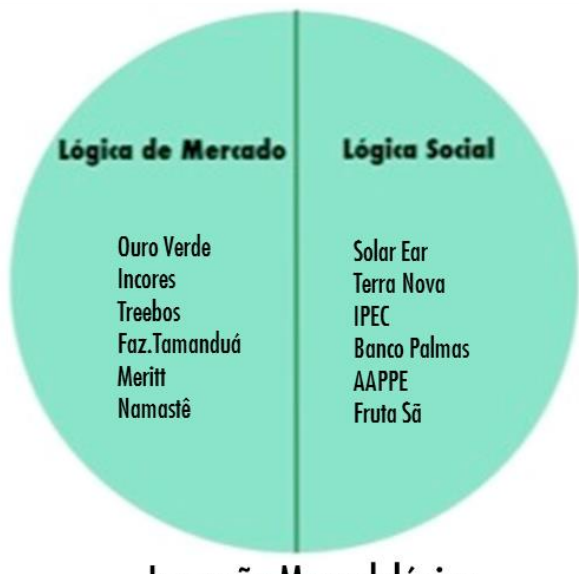

Inovação Mercadológica

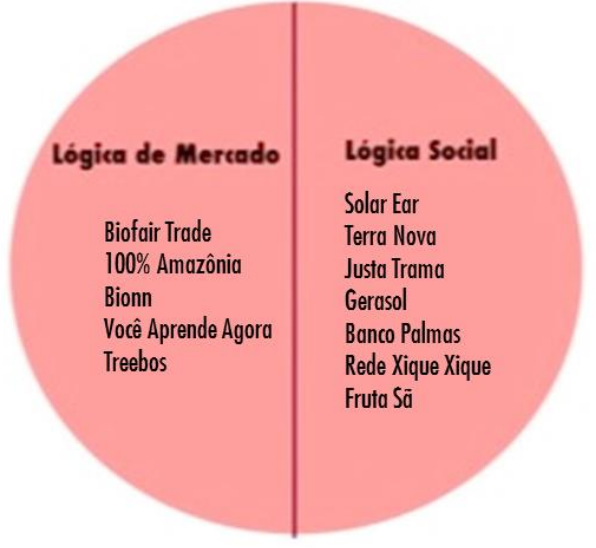

Inovaç̃̃o de Processo

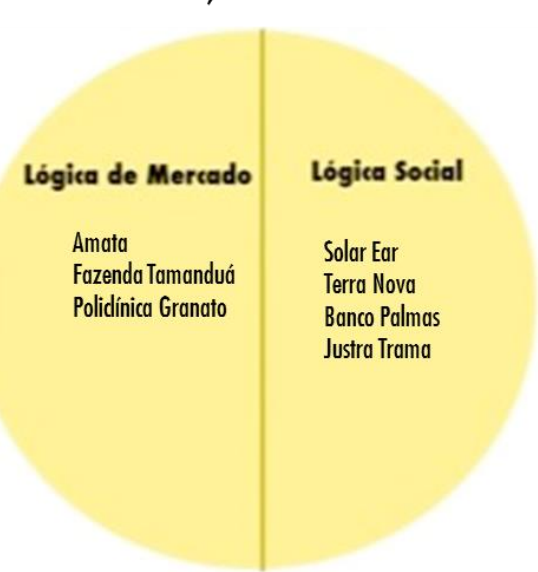

Inovação Organizacional

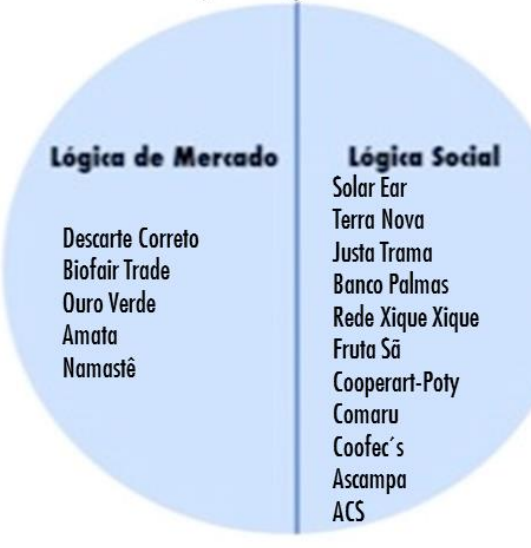

Fonte: elaborada pela autora

No que se refere à profundidade da inovação, são poucos os empreendimentos sociais que tem o potencial de reconfigurar a estrutura de seu mercado a partir de uma inovação considerada institucional (Fazenda Tamanduá, AAPPE, Ouro Verde, Justa Trama, Amata e Você Aprende Agora), tampouco provocar mudanças sistêmicas, em uma inovação disruptiva, criando um novo segmento em sua indústria (Banco Palmas, Terra Nova e Solar Ear). Como pode ser observado na Figura 17, a maioria dos casos (66\%) implementou inovações incrementais em uma determinada localidade, ou seja, simplesmente detectaram uma oportunidade em função de falhas de atuação do Estado ou falhas de mercado. Os negócios sociais com maior ênfase social tenderam a priorizar inovação em uma determinada localidade, talvez porque sua lógica de atuação pressupõe o estabelecimento de parcerias e colaborações em um município ou vivem a problemática de perto, algo a ser investigado em pesquisas futuras. 
Figura 17 - Profundidade e Abrangência da Inovação dos Casos Analisados

\section{Profundidade}

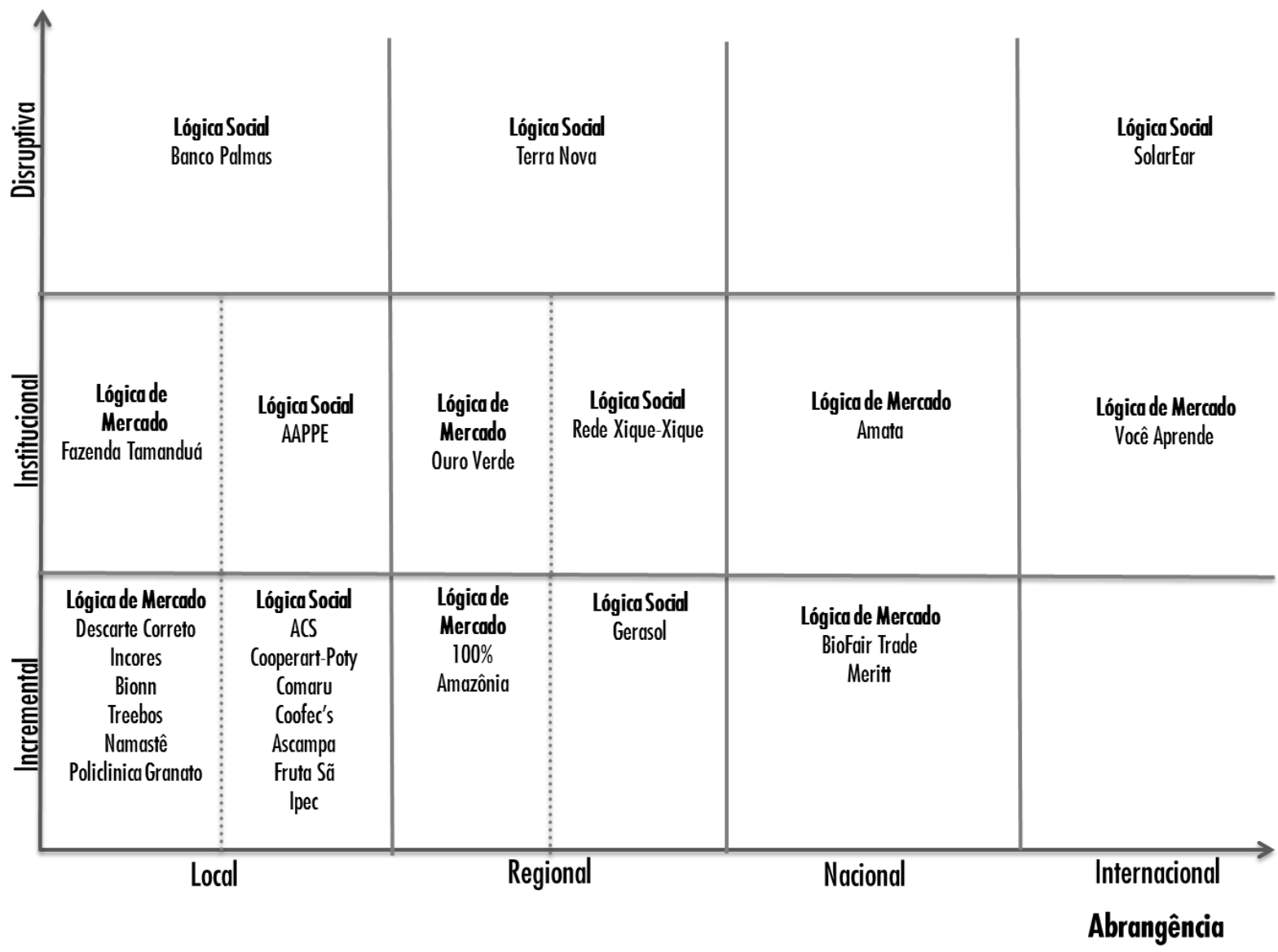

Fonte: elaborada pela autora

Os gargalos estruturais na área da educação, saúde e habitação exigem iniciativas com maior abrangência. A replicabilidade parece ser o grande desafio dos empreendimentos sociais brasileiros: 17 casos analisados tem abrangência local. Este espaço pode ser coberto por empreendimentos com uma visão de mercado mais ampliada, ou pautados por disponibilizar tecnologia social aberta, e que busquem inovações no processo produtivo para viabilizar crescimento quantitativo e escala.

A rica biodiversidade que o país possui e os impactos negativos gerados por uma economia de alto carbono não estão sendo muito explorados pelos negócios sociais estudados. Uma das explicações possíveis pode ser a prioridade dada por aceleradoras sociais para empreendimentos que atuam nas áreas sociais, aliviando ou substituindo os serviços 
oferecidos pelo Estado, particularmente em contextos urbanos, negligenciando o potencial de mercado em áreas rurais.

Ao analisar conjuntamente os resultados sobre geração de valor socioambiental atrelada aos fatores de profundidade e abrangência da inovação, observou-se uma possível diferença entre os negócios sociais com uma lógica de atuação social e os negócios com maior ênfase no mercado (vide figura 18).

Figura 18 - Matriz de Inovação Social
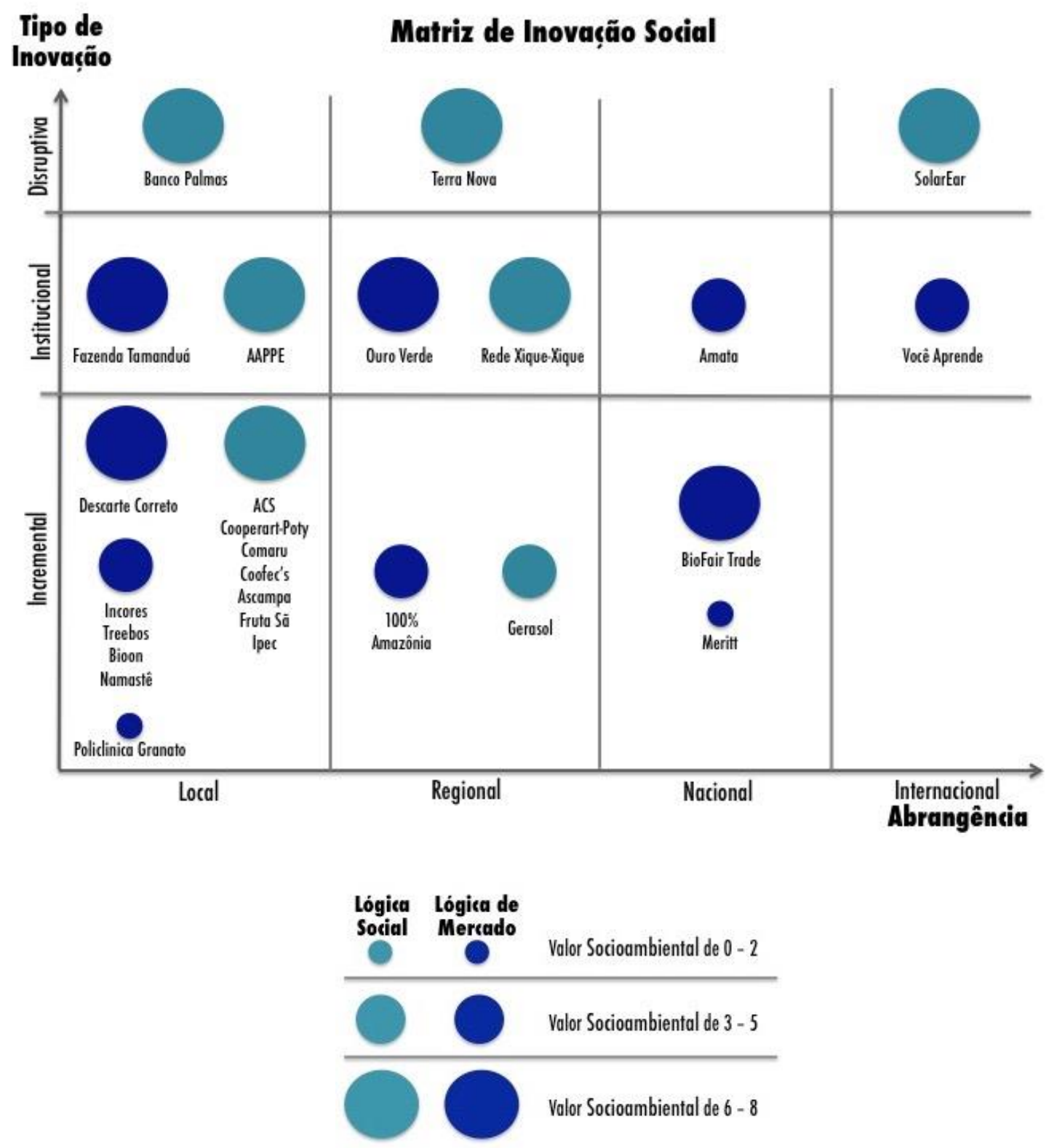

Fonte: elaborada pela autora 
Por um lado, a maior parte dos empreendimentos sociais com lógica social demonstrou a preocupação em gerar valor socioambiental em diferentes dimensões, porém com foco em um determinado local. Para isso, implementam inovações organizacionais em função da capacidade de fazer alianças e parcerias que possibilitem suprir uma falha de mercado. A contribuição destes empreendimentos para um desenvolvimento sustentável parece ser de maior profundidade, ou seja, qualitativa, com grande potencial para viabilizar transformações socioambientais locais.

Por outro lado, os empreendimentos com ênfase no mercado indicaram ser mais inovadores, diversificando produtos, preços e canais de distribuição, com potencial de provocar a reconfiguração de seu segmento. Sua contribuição é em termos de abrangência e, portanto, quantitativa e escalável. No entanto, eles geram contribuição em um menor número de dimensões em termos de valor socioambiental.

Em suma, a lógica de atuação social direciona impactos com maior profundidade que proporcionam o desenvolvimento local e a transformação social. Já a lógica de mercado tende a provocar impactos de maior abrangência em dimensões específicas do desenvolvimento sustentável.

Os negócios sociais geram também impactos nos segmentos em que atuam ao contestar o modus operandi tradicional de empresas capitalistas que tem como pressuposto a maximização do lucro sem considerar o retorno socioambiental.

No próximo capítulo, são apresentadas as considerações finais juntamente com as limitações deste estudo. 


\section{6 - Considerações finais}

Diferentes nomes têm sido utilizados para definir um fenômeno presente em todos os países que atuam no sistema capitalista: a existência de organizações que visam solucionar problemas socioambientais a partir de mecanismos de mercado. Instituições de ensino em administração consideradas ícones, como a Harvard Business School, já incorporaram no seu curriculum disciplinas e cursos direcionados para empreendimentos sociais ao reconhecer que as exigências feitas aos gestores deste tipo de organização são diferentes daquelas exigidas em uma empresa tradicional. No Brasil, o departamento de Administração da FEA/USP foi pioneiro na criação de disciplinas na graduação e pós-graduação, bem como na estruturação de Centro de Estudos voltado para esta temática no início da década de 1990.

Apesar de não ser um fenômeno recente, estudos bibliométricos realizados a partir da produção científica dos últimos vinte anos sobre o tema, tanto no âmbito nacional quanto internacional, constataram uma clara evolução dos trabalhos sobre negócios sociais somente a partir de 2006 (ROSOLEN; TISCOSKI; COMINI, 2015 e ROMANI, 2016).

Em uma reflexão retrospectiva e prospectiva do campo de empreendedorismo social e negócios sociais, os pesquisadores Barki, Comini, Cunliffe, Hart, \& Rai (2015) elencaram quatro focos de estudos: a primeira dimensão refere-se à conceitualização deste tipo de empreendimento, fundamental na construção de um campo novo (COMINI; BARKI; AGUIAR, 2012). Embora haja diferentes terminologias e correntes, há um consenso de que este tipo de organização é diferente em relação a uma empresa tradicional. A maximização de lucro para os acionistas cede lugar à maximização da geração valor socioambiental para a sociedade (DEES, 2001; AUSTIN; STEVENSON; WEI-SKILLERN, 2006; MARTIN; OSBERG, 2007). A segunda dimensão importante de pesquisa relaciona-se às estratégias e gestão de organizações híbridas, ou seja, como se estruturar para conseguir atingir objetivos até então vistos como contraditórios: lucratividade e impacto social (ALTER, 2007; SMITH; GONIN; BESHAROV, 2013; BATTILANA; LEE, 2014). O terceiro tema refere-se à inovação social, ou seja, como implementar novas soluções para melhorar a sociedade (MULGAN, 2006; MURRAY; CAULIER-GRICE; MULGAN, 2010; BIGNETTI, 2011) e resolver os problemas sociais e ambientais fruto de um crescimento econômico desordenado e insustentável (ABRAMOVAY, 2010). A quarta dimensão de estudo está relacionada com a mensuração do impacto gerado 
por empreendimentos sociais. Fundos de investimento que canalizam recursos para negócios sociais precisam quantificar os resultados obtidos (BANNICK; GOLDMAN, 2012; OLIVEIRA FILHO; KIYAMA; COMINI, 2013).

Este trabalho teve como objetivo contribuir para o avanço do campo de estudos de empreendimentos sociais, particularmente na dimensão sobre inovação social, por ter identificado algumas lacunas importantes na literatura: primeiro, os estudos encontrados sobre inovação social até o presente momento não fazem uma ponte entre inovação tradicional/tecnológica e inovação social, tratam esta última como um campo de estudo totalmente diferente (BIGNETTI, 2011); segundo, falta uma clara distinção entre os determinantes da inovação e as dimensões analíticas da inovação: processo e resultado (CROSSAN; APAYDIN, 2010); terceiro, há uma predominância de estudos que analisam a inovação na perspectiva de processo, havendo poucos trabalhos que utilizam a lente de resultado para analisar as inovações sociais (SHARRA; NYSSENS, 2010).

Por fim, os estudos de inovação social com uma abordagem de empreendedorismo social (DEES, 2001) associam este tipo inovação apenas às organizações sem fins lucrativos. A expansão de iniciativas de mercado que visam a geração de valor social e econômico, ocorrida na virada do século XXI, implica em rever este pressuposto, aceitando que o locus da inovação social possa ser também empresas com fins lucrativos (DE BRUIN; STANGL, 2013). A partir destas lacunas, delineou-se o problema de investigação: até que ponto os modelos de negócios sociais são geradores de inovação socioambiental?

Para obter respostas a esta inquietude acadêmica, este estudo deu continuidade aos resultados de uma pesquisa exploratória, conduzida pela autora, denominada Brasil27, cujos objetivos da primeira fase foram identificar e descrever empreendimentos existentes nos vinte e sete estados brasileiros que pudessem ser caracterizados como negócios sociais. Nesta segunda fase do projeto Brasil27, os objetivos foram: identificar até que ponto os negócios sociais são fonte de inovação e avaliar as possíveis correlações existentes entre características do empreendimento social com o tipo de inovação implementada. A inovação social foi analisada na perspectiva de resultado, ou seja, soluções novas (produto, processo, mercado ou organizacional) que tenham o potencial de gerar valor socioambiental para uma comunidade. 
Como apontado no referencial teórico, os negócios sociais caracterizam-se como organizações hibridas (BATTILANA et al., 2012; BATTILANA; LEE, 2014), porém com um espectro muito diversificado em seus modus operandi: alguns se assemelham a empresas tradicionais, com maior ênfase no mercado; outros negócios pautam sua atuação com uma lógica similar a de organizações da sociedade civil (independentemente de sua nomenclatura jurídica) com maior preocupação com a geração de valor socioambiental (ALTER, 2007).

Essa realidade indicou a necessidade de mapear esta pluralidade de atuação e, para tanto, foi elaborada uma régua para posicionar os tipos de empreendimentos sociais, representando um continuum da tipologia de negócios sociais. Ao analisar as diferentes definições e características de negócios sociais, foi possível elencar quatro fatores que demarcam as diferenças entre as abordagens/correntes encontradas na literatura sobre negócios sociais, a saber: finalidade do empreendimento, cadeia de valor, estrutura de governança e sustentabilidade financeira. O framework elaborado para construção deste continuum constitui uma das contribuições teóricas desta tese. Além disso, pode-se destacar a proposta de categorias analíticas para a observação de geração valor socioambiental. Estudos anteriores sobre negócios sociais focalizam apenas nas categorias de valor social (PORTOCARRERO; DELGADO, 2010), porém a dimensão ambiental não era considerada. O presente trabalho apresenta um espectro mais amplo, englobando nove categorias socioambientais que podem ser analisadas em conjunto, tal como aplicado aqui.

As experiências brasileiras de negócios sociais analisadas neste estudo reforçam a observação de que no Brasil não há a predominância de um único modelo de negócio social. Pelo contrário, há uma convivência de diferentes formatos jurídicos (empresa, associação, cooperativas) com lógica de atuação bem diversificada nas cinco regiões geográficas. $\mathrm{Na}$ Europa Ocidental, Ásia e na América do Norte, legislações específicas foram criadas para delimitar com maior precisão o formato de negócios sociais e, ao mesmo tempo, viabilizar um ambiente mais propício para sua consolidação. Na América Latina, o debate sobre a importância da criação de um formato jurídico específico para organizações híbridas tem sido impulsionado pelos atores que participam do Sistema $\mathrm{B}^{12}$, movimento que tem como

\footnotetext{
${ }^{12}$ O Sistema B é a organização responsável pela disseminação do movimento B-Corp na América Latina. O B-Corp foi criado nos Estados Unidos, em 2007, pela organização sem fins lucrativos B-Lab com o objetivo estimular a criação e certificação de empresas comprometidas com a geração de valor socioambiental, ou seja, geração de lucro juntamente com impactos sociais. No Brasil, o movimento foi oficialmente lançado em outubro de 2013 (FIDELHOC; COMINI; RODRIGUES, 2014).
} 
objetivo estimular a estruturação de negócios que visem a geração de valor compartilhado (RODRIGUES et al., 2015).

Os fatores que mais diferenciaram os empreendimentos deste estudo foram governança e cadeia de valor. Os empreendimentos com maior ênfase social tendem a criar instâncias de participação das comunidades nas quais atua. Além disso, buscam contratar colaboradores e fornecedores de segmentos da população em situação de maior vulnerabilidade socioeconômica.

Embora existam modelos de negócios sociais muito diferentes entre si, identificou-se uma possível relação entre o posicionamento do empreendimento e a geração de valor socioambiental: os empreendimentos com maior orientação social (lógica social) geram mais contribuições diretas e indiretas em termos de valor socioambiental (capital físico, capital produtivo, capital natural, economia de baixo carbono, capital humano, custos de transação, reuso de materiais, capital social e cidadania) do que os empreendimentos sociais que atuam com uma lógica de mercado. É importante ressaltar que esta análise teve como princípio traduzir a intencionalidade do empreendimento e não mensurar o seu impacto.

Em termos gerais, observou-se que os empreendimentos socioambientais são mais sociais do que ambientais, suas atividades são desenvolvidas visando, prioritariamente, a geração de renda (capital produtivo), profissionalização, acesso aos serviços de saúde e oferta de produtos saudáveis (capital humano). Nesse sentido, há um grande desafio e oportunidade para o desenvolvimento de empreendimentos que conciliem valor social e ambiental de forma unívoca a fim de contribuir para diminuição da pobreza, mas, também, para a conservação da biodiversidade e desenvolvimento de uma economia de baixo carbono e com menor uso de recursos (economia circular).

A capacidade inovadora dos empreendimentos sociais foi avaliada por meio da caracterização da forma de inovação (produto, processo, mercado ou organizacional); profundidade (magnitude da inovação) e abrangência (difusão da inovação).

Embora os negócios sociais gerem muito valor socioambiental, pode-se dizer que sua capacidade inovadora ainda é baixa: a maioria dos casos (66\%) implementou inovações incrementais em uma determinada localidade, aproveitando lacunas de mercado ou falhas de atuação do Estado. Poucos negócios sociais oferecem produtos/serviços que tem 
potencial para reconfigurar a estrutura de seu mercado ou criar um novo segmento em sua indústria. No entanto, tem potencial para reconfigurar o mercado no que se refere a princípios e valores visto que contestam o modus operandi tradicional de empresas capitalistas que tem como único pressuposto a maximização do lucro sem considerar a geração de valor socioambiental.

Pouca ênfase foi dada para a implementação de novos métodos de produção que visem a redução de custos (inovação de processo): a maior parte dos empreendimentos sociais (17) implementaram inovações a partir do estabelecimento de parcerias e alianças (inovação organizacional) e com diferentes canais de venda ou preços (inovação de mercado). Foi identificada uma possível relação entre empreendimentos sociais com lógica de atuação social e a implementação de inovação organizacional. Isto significa que negócios sociais com lógica social tendem a valorizar o estabelecimento de parcerias entre organizações e estimulam o compartilhamento de saberes entre os atores. Em negócios sociais com lógica de mercado, observou-se maior capacidade de implementação de inovações de produto e mercadológica.

Este estudo revelou que negócios sociais com lógica de mercado e com lógica social têm papéis e contribuições diferentes na proposição de alternativas para um desenvolvimento sustentável: negócios sociais com uma forte orientação social tendem a priorizar uma ação local e buscam gerar valor socioambiental em diferentes dimensões. Nesse sentido, pode-se dizer que sua contribuição é qualitativa com maior profundidade do impacto.

Por outro lado, os negócios sociais com lógica de atuação de mercado demonstraram ter maior preocupação com escala, maior capacidade para introduzir inovações em produto ou mercadológicas, tendendo a provocar mudanças institucionais em sua indústria. Pode-se dizer, portanto, que a contribuição destes empreendimentos é quantitativa com maior abrangência do impacto.

Por fim, é importante ressaltar que a contribuição efetiva de organizações híbridas, como os negócios sociais, a uma sociedade mais inclusiva e ambientalmente responsável pressupõe que os gestores deste tipo de empreendimento reconheçam o princípio da "incompletude institucional", ou seja, nenhuma instituição isolada conseguirá resolver os grandes problemas relacionados à pobreza e à degradação ambiental. A criação de valor socioambiental deve ser vista como objetivo prioritário e a criação de valor econômico como 
um objetivo necessário. Obter valor social e econômico exige dos profissionais que atuam em negócios socioambientais visão de longo prazo, levando em conta que os resultados não são obtidos no curto prazo, visão de mercado, para conseguir delinear estratégias e gerir recursos por meio de princípios de eficiência e eficácia e, principalmente, visão sistêmica, para compreensão das causas e sintomas dos problemas socioambientais vividos hoje em dia. Somado a estes aspectos, são necessárias atitudes como criatividade e persistência alinhadas com capacidade de inovação.

Em resumo, este trabalho reforça o argumento de que os negócios sociais têm um papel importante na superação dos problemas sociais, econômicos, tecnológicos e ambientais existentes no país. No entanto, para se transformarem em agentes indutores do desenvolvimento sustentável, é necessário consolidar seu modelo de negócio, saindo de um estágio inicial de testes de estratégias.

A título de limitações, dentro da complexidade inerente ao tema de desenvolvimento sustentável, este estudo abordou apenas um tipo de organização - empreendimentos sociais - na perspectiva de seus fundadores. Uma análise mais abrangente deveria incorporar a visão dos clientes e dos beneficiários para obter com precisão o impacto gerado pelo negócio social vis-à-vis a intencionalidade de seus fundadores. Entretanto, uma ampliação dos sujeitos da pesquisa mudaria o escopo da pesquisa, tornando-a um estudo de mensuração de impacto e não de inovação, objeto central deste trabalho.

Como a caracterização de negócios sociais, objeto deste estudo, se dá pela análise da intencionalidade de sua ação, e não pelo seu formato jurídico, também fica impossibilitada a definição do universo "real" da pesquisa e a representatividade dos 27 casos analisados. A inexistência de um banco de dados estruturado exigiu a constituição de um universo estimado de negócios sociais a partir de indicações dos principais atores do campo (aceleradores, organizações de fomento e investidores). Levando em conta que é um setor que apresenta uma taxa de crescimento acelerado, o número total de empreendimentos sociais que compõem o banco de dados deve estar desatualizado em relação aos dias atuais. Por ser um estudo exploratório, com enfoque qualitativo, os resultados obtidos devem ser contextualizados, não sendo passíveis de generalização. No entanto, permitem delinear algumas hipóteses a serem testadas em trabalhos quantitativos, tais como: 
1) Negócios Sociais com lógica de atuação social desenvolvem mais inovações organizacionais do que inovações nos processos;

2) Negócios Sociais com lógica de mercado desenvolvem mais inovações de produto do que organizacionais;

3) Negócios Sociais com lógica de atuação social geram maior impacto socioambiental em termos qualitativos;

4) Negócios Sociais com lógica de atuação de mercado geram maior impacto socioambiental quantitativo.

Finalmente, as considerações feitas neste trabalho sobre a capacidade de inovação dos empreendimentos sociais não pretendem esgotar a reflexão do tema. Como apresentam Crossan e Apaydin (2010), é necessário fazer uma clara distinção entre os determinantes da inovação e as dimensões da inovação.

Este estudo privilegiou a perspectiva de resultado dentro da dimensão da inovação, procurando respostas para o que está sendo feito e para qual finalidade (what? e what kind?). São necessários levantamentos empíricos em negócios sociais que procurem analisar a dimensão de processo, respondendo a pergunta sobre como ocorre a inovação (how?) e, principalmente, que identifiquem os determinantes da inovação em diferentes tipos de negócios sociais (liderança, competências organizacionais e gestão). Recomenda-se ainda um olhar mais preciso sobre os tipos de inovação (por meio da definição de uma escala de mensuração) e levantamento mais ampliado (por meio da visão de diferentes stakeholders).

A emergência dos negócios sociais propiciou o surgimento do que pode ser chamado um "ecossistema" do empreendedorismo social. Nele identificam-se como principais atores, em primeiro lugar, os empreendedores, isto é, pessoas ou grupos sociais que, a partir de uma ideia geralmente inovadora, propõem-se a empreender um determinado negócio capaz de gerar, simultaneamente, valor social e valor econômico. Os empreendedores são apoiados por aceleradoras ou incubadoras que oferecem suporte ao projeto para que este adquira maturidade em termos organizacionais e de gestão, acelerando a constituição do empreendimento. Em terceiro lugar, tem-se a figura dos investidores, que destinam capitais a negócios sociais que consideram potenciais promotores de impacto social. Faltam estudos científicos que identifiquem os principais desafios para a consolidação dos negócios sociais 
no Brasil e mensurem as contribuições efetivas dos atores de suporte para esta consolidação.

O campo de negócios sociais tem estimulado o engajamento de jovens no País que já vislumbram um futuro profissional como empreendedores sociais ou como colaboradores neste tipo de empreendimento visto que os mesmos propiciam um trabalho com mais sentido e significativo (ROSOLEN, 2014). É necessário desenvolver estudos que identifiquem as diversas práticas utilizadas em gestão de pessoas por este tipo de empreendimento e avalie a capacidade de atração e retenção de jovens talentosos em negócios sociais.

Espera-se que o estudo aqui desenvolvido sirva de inspiração para outras iniciativas e pesquisas que também busquem o fortalecimento do campo de negócios sociais inovadores e geradores de valor socioambiental. Dessa maneira, será possível estimular a abertura de novos espaços de realização pessoal e profissional a todos que acreditam que podem fazer a diferença na sociedade rumo ao desenvolvimento sustentável. 


\section{Referências}

ABRAMOVAY, R. O que os economistas pensam sobre sustentabilidade. São Paulo: Editora $34,2010$.

ALTER, K. Social Enterprise Typology, Virtue Ventures LLC, 2007.

ALVES-MAZZOTTI, A. GEWANDSZNAJDER, F. O método nas ciências naturais e sociais: pesquisa quantitativa e qualitativa. São Paulo: Pioneira, 1998.

AUSTIN, J. The collaboration challenge: how non profits and businesses succeed through strategic. San Francisco: Jossey-Bass, 2002.

AUSTIN, J.; STEVENSON, H.; WEI-SKILLERN, J. Social and commercial entrepreneurship: Same, different, or both? Entrepreneurship: Theory and Practice, v. 30, n. 1, p. 1-22, 2006.

BANNICK, M.; GOLDMAN, P. Priming the Pump: The Case for a Sector Based Approach to Impact InvestingOmidyar Network, , 2012. .

BARDIN, L. Análise de conteúdo. Lisboa: Edições 70, 1994.

BARKI, E.; COMINI, G.; CUNLIFFE, A.; HART, S.; RAI, S. Social Entrepreneurship and Social Business: Retrospective and Prospective Research. RAE-Revista de Administração de Empresas, v. 55, n. 4, p. 380-384, 2015.

BATTILANA, J.; LEE, M. Advancing Research on Hybrid Organizing - Insights from the Study of Social Enterprises. The Academy of Management Annals, v. 8, n. 1, p. 397-441, 2014.

BATTILANA, J.; LEE, M.; WALKER, J.; DORSEY, C. In Search of the Hybrid Ideal. Stanford Social Innovation Review, v. 10, n. 3 (Summer), p. 51-55, 2012.

BIGNETTI, L. P. As inovações sociais: uma incursão por ideias, tendências e focos de pesquisa. Ciências Sociais Unisinos, v. 47, n. 1, p. 3-14, 2011.

B-LAB. Benefit Corporation. Disponível em: <http://benefitcorp.net/>. Acesso em: 20 jun. 2016.

BORZAGA, C.; DEFOURNY, J. The emergence of social enterprise. Trento (Italy): Edizioni31, 2001.

CELLI, J. B.; GONZÁLEZ, R. A. Market-Based Initiatives for Low-Income Sectors and Economic Value Creation. In: SOCIAL ENTERPRISE KNOWLEDGE NETWORK - SEKN (Ed.). Socially inclusive business: Engaging the poor through market initiatives in Iberoamerica. Cambridge: Harvard University Press, 2010, p. 229-259.

CHESBROUGH, H. Open Innovation: A New Paradigm for Understanding Industrial Innovation. In: CHESBROUGH, H.; VANHAVERBEKE, W.; WEST, J. (Ed.). Open Innovation: Researching a New Paradigm. Oxford: Oxford University Press, 2006. p. 1-12.

CHRISTENSEN, C. M.; BAUMANN, H.; RUGGLES, R.; SADTLER, T. M. Disruptive Innovation for 
Social Change. Harvard Business Review, v. 84, n. 12, p. 94-101, 2006.

CHU, M. Is it fair to do business with the poor? In: Geneva Papers on Inclusiveness Symposium Special Issue, Geneva. Anais... Geneva: World Microfinance Forum Geneva, 2008. Disponível em: <www.microfinanceforum.org>.

COLEMAN, J. S. Social Capital in the Creation of Human Capital. The American Journal of Sociology, v. 94, n. Supplement, p. 95-120, 1988.

COMINI, G.; BARKI, E.; AGUIAR, L. T. De. A three-pronged approach to social business: a Brazilian multi-case analysis social businesses. Revista de Administração, v. 47, n. 3, p. 385397, 2012.

COONEY, K.; KOUSHYAR, J.; LEE, M.; MURRAY, J. Benefit Corporation and L3C adoption: a survey. Stanford Social Innovation Review, v. online, n. Dez, 2014.

CROSSAN, M. M.; APAYDIN, M. A multi-dimensional framework of organizational innovation: A systematic review of the literature. Journal of Management Studies, v. 47, n. 6, p. 11541191, 2010.

DE BRUIN, A.; STANGL, L. M. The Social Innovation Continuum: Towards Addressing Definitional Ambiguity. In: EMES-SOCENT Conference Selected Papers, Liege. Anais... Liege: EMES, 2013.

DEES, J. G. The Meaning Social Entrepreneur. Durham, NC: Duke University, 2001. .

DEFOURNY, J.; NYSSENS, M. The EMES Approach of Social Enterprise in a Comparative Perspective. 2012 [s.l: s.n.].

DRUCKER, P. Inovação e espírito empreendedor: prática e princípios. 4. ed. São Paulo: Pioneira, 1987.

DTI. Social enterprise: a strategy for success. 2012 [s.l: s.n.]. Disponível em: <http://www.dti.gov.uk/>. Acesso em 15 de junho de 2016.

EISENHARDT, K. M. Building theories from case study research. Academy of Management Review, v. 14, n. 4, p. 532-550, 1989.

EMES. EMES. Disponível em: <http://emes.net/>. Acesso em: 27 jun. 2016.

FIDELHOC, M.; COMINI, G. M.; RODRIGUES, J. Empresas B: Princípios e desafios do Movimento B Corp. Palavras-chave: In: XVII SemeAd, São Paulo. Anais... São Paulo: FEA-USP, 2014.

FISCHER, R. M.; COMINI, G. Sustainable development: from responsibility to entrepreneurship. Revista de Administração, v. 47, n. 3, p. 363-369, 2012.

GALERA, G.; BORZAGA, C. Social enterprise: An international overview of its conceptual evolution and legal implementation. Social Enterprise Journal, v. 5, n. 3, p. 210-228, 2009. 
GEPHART, R. Paradigms and Research Methods. In: Academy of Management, Researh Methods Forum, Summer, Anais...1999.

GIIN - GLOBAL IMPACT INVESTING NETWORK. IRIS - Impact Reporting \& Investment Standards. Disponível em: <http://iris.thegiin.org>. Acesso em: 15 jun. 2011.

GIL, A. C. Métodos e técnicas de pesquisa social. São Paulo: Atlas, 1994.

GRAZIANO, L. Pluralismo em perspectiva comparativa: notas sobre as tradições europeia e americana. Communist and Post-Communist Studies, v. 26, n. 4, p. 341-351, 1993.

GUTIÉRREZ, R.; EZEQUIEL, R.; TRUJILLO, D. Empresas sociales: ¿una especie en busca de reconocimiento? Revista de Administração-RAUSP, v. 41, n. 4, p. 404-418, 2006.

J.P.MORGAN. Impact Investments. An Emerging Asset Class. Global ResearchJ. P. Morgan, , 2010.

KARNANI, A. The mirage of marketing to the bottom of the pyramid: how the private sector can help alleviate poverty. California Management Review, v. 49, n. 4, p. 90-112, 2007.

KERLIN, J. Social enterprise in the united states and europe: understanding and learning from the differences. International Journal of Voluntary and Nonprofit Organizations, v. 17, n. 3, p. 251, 2006.

KHANNA, T.; PALEPU, K. Emerging giants: building world-class companies in developing countries. Harvard Business Review, v. 84, n. 10, p. 60-69, 2006.

LANGLEY, a.; ABDALLAH, C. Templates and Turns in Qualtative Studies of Strategy and Management. Research Methodology in Strategy and Management, v. 6, n. 2011, p. 201235, 2011.

MAANEN, J. Van. Reclaiming qualitative methods for organizational research: A preface. Administrative Science Quarterly, p. 520-527, 1979.

MÁRQUEZ, P.; REFICCO, E.; BERGER, G. Negocios Inclusivos en America Latina. Harvard Business Review, v. 87, n. 5, p. 28-38, 2009.

MÁRQUEZ, P.; REFICCO, E.; BERGER, G. Introduction: A fresh look at markets and the poor. In: SOCIAL ENTERPRISE KNOWLEDGE NETWORK - SEKN (Ed.). Socially inclusive business: Engaging the poor through market initiatives in Iberoamerica. Cambridge: Harvard University Press, 2010. p. 1-25.

MARTIN, R. L.; OSBERG, S. Social Entrepreneurship: The Case for Definition. Stanford Social Innovation Review, v. Spring, p. 29-39, 2007.

MARTINS, G.; THEÓPHILO, C. Metodologia da investigação científica para ciências sociais aplicadas. São Paulo: Atlas, 2009.

MEA. Ecosystems and human well-being: synthesis. Washington, DC: Island Press, 2005. 
MENDOZA, R. U. Why do the poor pay more? Exploring the poverty penalty concept. Journal of International Development, v. 23, n. 1, p. 1-28, jan. 2011.

MILES, M. B.; HUBERMAN, A. M. Qualitative data analysis: a sourcebook of new methods. Newbury Park, CA: Sage, 1984.

MOULAERT, F.; MACCALLUM, D.; MEHMOOD, A.; HAMDOUCH, A. General introduction: the return of social innovation as a scientific concept and a social practice. In: FRANK MOULAERT; MACCALLUM, D.; MEHMOOD, A.; HAMDOUCH, A. (Ed.). The International Handbook on Social Innovation. Cheltenham, UK: Edward Elgar Publishing, 2013.

MULGAN, G. The Process of Social Innovation. Innovations: Technology, Governance, Globalization, v. 1, n. 2, p. 145-162, abr. 2006.

MURRAY, R.; CAULIER-GRICE, J.; MULGAN, G. The open book of social innovations. Social innovator series: ways to design, develop and grow social innovations. The Young Foundation, v. 30, n. 8, p. 224, 2010.

NERI, M. Mapa de ativos: combate sustentável à pobreza. 2001 [s.I: s.n.].

NICHOLLS, A. Playing the field. Social Enterprise Journal, v. 2, n. 1, p. 1-5, 2006.

OECD. Social enterprises. Paris: OECD Publishing, 1999.

OECD. Oslo manual. 3rd Editio ed. Paris: OECD Publishing, 2005.

OLIVEIRA FILHO, G. R.; KIYAMA, R. S.; COMINI, G. M. Os Desafios de Mensurar o Impacto Social. In: Negócios Sociais com impacto social no Brasil. São Paulo: Peirópolis, 2013. p. 212-235.

OSTROM, E. Coping with tragedies of the commons. Annual Review of Political Science, v. 2, n. june, p. 493-535, 1999.

PÁDUA, C. Palestra sobre áreas de atuação em Negócios Socioambientais, Nazaré Paulista, Instituto de Pesquisas Ecológicas - IPÊ, 2015.

PHILLS, J.; DEIGLMEIER, K.; MILLER, D. Rediscovering social innovation. Stanford Social Innovation Review, v. Fall, p. 34-43, 2008.

POL, E.; VILLE, S. Social innovation: Buzz word or enduring term? Journal of SocioEconomics, v. 38, n. 6, p. 878-885, 2009.

PORTOCARRERO, F.; DELGADO, Á. J. Inclusive Business and Social Value Creation. In: SOCIAL ENTERPRISE KNOWLEDGE NETWORK - SEKN (Ed.). Social Inclusive Business. [s.I.] SEKN, 2010. p. 261-293.

POZZEBON, M.; PETRINI, M. Critérios para Condução e Avaliação de Pesquisas Qualitativas de Natureza Crítico-Interpretativa. Pesquisa Qualitativa em Administração: fundamnetos, métodos e usos no Brasil., p. 51-72, 2013. 
PRAHALAD, C. K.; HART, S. The fortune at the bottom of the pyramid. Strategy + Business, v. 1, n. 26, p. 1-14, 2002.

RODRIGUES, J.; COMINI, G.; FISCHER, R. M.; DUJARDIN, F.; SANTOS, A. P. S. dos. The B Corporation Movement in Brazil: A Portrait of Certified Companies. Academy of Management Proceedings , v. 2015 , n. 1, 2015.

ROMANI, M.; Negócios Sociais: Estudo Bibliométrico e Análise Sistemática da Literatura Nacional e Internacional.2016. Dissertação (Mestrado em Administração). Centro Universitário da FEI. São Paulo, São Paulo, 2016.

ROSOLEN, T. Negócios sociais e valores pessoais: um estudo quantitativo com estudantes de administração. 2014. Dissertação (Mestrado em Administração). Faculdade de Economia, Administração e Contabilidade da Universidade de São Paulo, São Paulo, 2014.

ROSOLEN, T.; TISCOSKI, G. P.; COMINI, G. M. Empreendedorismo social e negócios sociais: Um estudo bibliométrico da publicação nacional e internacional. In: SANTANA, A. L. J. DE M. $D E ;$ SOUZA, L. M. DE (Ed.). Empreendedorismo com foco em negócios sociais. Curitiba: NITS UFPR, 2015. p. 139-163.

RYNES, S.; GEPHART, R. P. Qualitative research and the Academy of Management Journal. Academy of Management Journal, v. 47, n. 4, p. 454-462, 2004.

SELLTIZ, C.; JAHODA, M.; DEUTSCH, M.; COOK, S. M. Métodos de pesquisa nas relações sociais. São Paulo: EPU, 1974.

SEN, A. Desenvolvimento como liberdade. São Paulo: Companhia das Letras, 2000.

SHARRA, R.; NYSSENS, M. Social Innovation: an Interdisciplinary and Critical Review of the Concept. 2010 [s.l: s.n.].

SILVEIRA, F. F.; TURRI, S. N. Z. Inovação Social: Um Estudo Bibliométrico Identificando Principais Temas, Autores, Citações e Cocitações ao longo de 20 anos. In: Anais do XXXIX EnANPAD 2015, Belo Horizonte. Anais... Belo Horizonte: Anpad, 2015.

SMITH, W. K.; GONIN, M.; BESHAROV, M. L. Managing Social-Businnes Tensions: A Review and Research Agenda for Social Enterprise. Business Ethics Quarterly, v. 3, n. July 2013, p. 407-442, 2013.

SOCIAL ENTERPRISE COALITION. There is more to business than you think. A guide to Social EnterpriseLondonSocial Enterprise Coalition, , 2003. .

TEEB. TEEB - The Economics of Ecosystems and Biodiversity for International and National Policy Makers. 2009 [s.l: s.n.].

TORRES, H.; BARKI, E.; COMINI, G. Benefits Arising From Social Business in Brazil: A Critical Analysis. Working paper, 2015 [s.l: s.n.]. 
TORRES, H. G.; BARKI, E. Por uma Classificação dos Negócios com Impacto Social. In: VII ENAPEGS - Encontro Nacional de Pesquisadores em Gestão Social, Belém, PA. Anais... Belém, PA: Unama - Universidade da Amazônia, 2013.

TRAVAGLINI, C.; BANDINI, F.; MANCIONE, K. Social enterprises in europe: governance models. an analysis of social enterprises governance models through a comparative study of the legislation of eleven countries. In: 2nd EMES International Conference on Social Enterprise, Trento (Italy). Anais... Trento (Italy): EMES, 2009.

VERGARA, S. Métodos de pesquisa em administração. São Paulo: Atlas, 2012.

YIN, R. K. Estudo de caso - planejamento e métodos. 2. ed. Porto Alegre: Bookman, 2001.

YOUNG, D. R. Alternative perspectives on social enterprise. In: CORDES, J. J.; STEUERLE, C. E. (Ed.). Nonprofits and business. Washington, DC: The Urban Institute Press, 2008. p. 21-46.

YUNUS, M. Creating a world without poverty: social business and the future of capitalism. New York: Public Affairs, 2007. 
1. Rio Grande do Sul: Justa Trama - cooperativa inclusiva de segundo grau que trabalha toda a cadeia do algodão orgânico.

1. Artigo: Publicado em 01/07/2013 - http://folha.com/no1303003

2. Vídeo: https://www.youtube.com/watch?v=YbaJTswcDCM

2. Santa Catarina: Meritt - startup de tecnologia que oferece ferramentas de gestão para melhoria do sistema educacional.

1. Artigo: Publicado em 08/07/2013 - http://folha.com/no1306944

2. Vídeo: https://www.youtube.com/watch?v=IvYfydl_mVc

3. Paraná: Terra Nova - empresa que trabalha com a regularização fundiária de terras habitadas irregularmente.

1. Artigo: Publicado em 15/07/2013 - http://folha.com/no1310226

2. Vídeo: https://www.youtube.com/watch?v=i-yxVjTJ5W4

4. Bahia: INCORES - empresa que capacita emprega jovens de comunidades carentes por meio de programas de jovens aprendizes.

1. Artigo: Publicado em 22/07/2013 - http://folha.com/no1313976

2. Vídeo: https://www.youtube.com/watch?v=G0xx2JKaNtE

5. Sergipe: Namastê - empresa de chás e especiarias orgânicas que trabalha na inclusão de trabalhadores rurais em situação de vulnerabilidade socioeconômica.

1. Artigo: Publicado em 29/07/2013 - http://folha.com/no1318330

2. Vídeo: https://www.youtube.com/watch?v=c6JA2JLaKQU

6. Alagoas: AAPPE - entidade que oferece serviços de educação, saúde e integração social a pessoas com deficiência auditiva.

1. Artigo: Publicado em 05/08/2013 - http://folha.com/no1321845

2. Vídeo: https://www.youtube.com/watch?v=vqXKty5oRmc

7. Pernambuco: Bio Fair Trade - empresa que capacita grupos de artesãos e os conecta com o mercado consumidor nacional e europeu.

1. Artigo: Publicado em 12/08/2013 - http://folha.com/no1325081

2. Vídeo: https://www.youtube.com/watch?v=5t9KpM2bcp0

8. Paraíba: Fazenda Tamanduá - empresa que desenvolve culturas orgânicas no sertão da Paraíba e apoia pequenos agricultores no acesso ao mercado.

1. Artigo: Publicado em 19/08/2013 - http://folha.com/no1328552

2. Vídeo: https://www.youtube.com/watch?v=aOLuYOw4KE4

9. Rio Grande do Norte: Rede Xique-Xique - união de empreendimentos de economia solidária que juntos criaram uma rede de apoio mútuo, consumo interno, e acesso ao mercado.

1. Artigo: Publicado em 26/08/2013 - http://folha.com/no1331985

2. Vídeo: : https://www.youtube.com/watch?v=20y-h4jt7h0

10. Ceará: Banco Palmas - pioneiro no conceito de banco comunitário de desenvolvimento, oferece uma gama de serviços financeiros que visam desenvolver a comunidade onde está localizado.

1. Artigo: Publicado em 09/09/2013 - http://folha.com/no1339094

2. Vídeo: https://www.youtube.com/watch?v=NOT6meWBOaM

11. Piauí: Cooperart Poty - cooperativa criada por mulheres de uma das comunidades mais pobres de Palmas e que quebrou a hegenomia do homem na produção de artesanato de cerâmica.

1. Artigo: Publicado em 16/09/2013 - http://folha.com/no1342571

2. Vídeo: http://www.youtube.com/watch?v=IlcBfRWqXCU

12. Pará: $\mathbf{1 0 0 \%}$ Amazônia - Empresa que conecta produtores extrativista da Amazônia com clientes estrangeiros.

1. Artigo: Publicado em 23/09/2013 - http://folha.com/no1346070

2. Vídeo: http://www.youtube.com/watch?v=mnh2v11w93M

13. Amapá: Comaru - Cooperativa de coletadores e extrativistas de castanha do Pará, que beneficia o produto in natura e revende o óleo a uma grande empresa de cosméticos.

1. Artigo: Publicado em 30/09/2013 - http://folha.com/no1349433

2. Vídeo: http://www.youtube.com/watch?v=PJYQOqKvCfc 
14. Roraima: Coofecs - cooperativa de costureiras de Boa Vista, hoje a única confecção cooperativa do estado.

1. Artigo: Publicado em 07/10/2013 - http://folha.com/no1352978

2. Vídeo:http://www.youtube.com/watch?v=vkXsOqOhKZc

15. Amazonas: Descarte Correto - empresa que trabalha na logística reversa do lixo eletrônico ao mesmo tempo em que educa e capacita profissionalmente jovens de comunidades de baixa renda.

1. Artigo: Publicado em 14/10/2013 - http://folha.com/no1355288

2. Vídeo:http://www.youtube.com/watch?v=fguGKpmCRkQ

16. Acre: ACS Amazônia - Associação que trabalha como organismo de controle social para a venda direta de produtos orgânicos, uma forma participativa e acessível de garantir a procedência de alimentos.

1. Artigo: Publicado em 29/10/2013 - http://folha.com/no1364078

2. Vídeo: http://www.youtube.com/watch?v=mNEI6v93dLA

17. Mato Grosso: Ouro Verde Amazônia - empresa que por meio do comércio justo busca mudar a realidade de uma das cadeias produtivas mais antigas do país, a da castanha do pará.

1. Artigo: Publicado em 04/11/2013 - http://folha.com/no1365591

2. Vídeo:http://www.youtube.com/watch?v=uZ5wdWwARy8

18. Tocantins: Ascampa - cooperativa de catadores de lixo reciclável que gera a seus cooperados renda que não conseguiriam sozinhos

1. Artigo: Publicado em 11/11/2013 - http://folha.com/no1368793

2. Vídeo:http://www.youtube.com/watch?v=WYeytqMBo78

19. Distrito Federal: Bioon - ecomercado que trabalha alternativas de comercialização de produtos naturais afim de quebrar o ciclo baixa escala - alto preço.

1. Artigo: Publicado em 18/11/2013 - http://folha.com/no1372298

2. Vídeo:http://www.youtube.com/watch?v=NagC3ee73IE

20. Goiás: IPEC - centro de permacultura pioneiro no Brasil e que desenvolve tecnologias sustentáveis de habitação e produção de energia e de alimentos.

1. Artigo: Publicado em 25/11/2013 - http://folha.com/no1376357

2. Vídeo:http://www.youtube.com/watch?v=u2zGT AR4kM

21. Maranhão: Fruta Sã - empresa que, por meio da comercialização de polpas de frutas silvestres, trabalha para o desenvolvimento social de comunidades indígenas e a conservação do cerrado

1. Artigo: Publicado em 02/12/2013 - http://folha.com/no1379599

2. Vídeo: http://www.youtube.com/watch?v=nXLkpplHMrO

22. Mato Grosso do Sul: Você Aprende Agora - iniciativa que oferece curso de línguas gratuitamente pela internet

1. Artigo: Publicado em 10/12/2013 - http://folha.com/no1383528

2. Vídeo: http://www.youtube.com/watch?v=FobliQefT9o

23. Espirito Santo: Treebos - empresa que oferece o serviço de adoção de árvores frutíferas, dentre outros relacionados à agricultura sustentável

1. Artigo: Publicado em 16/12/2013 - http://folha.com/no1385120

2. Vídeo:http://www.youtube.com/watch?v=WBqrALsjB40

24. Minas Gerais: Gerassol - iniciativa que vende aquecedores solares de baixo custo e capacita pessoas de qualquer nível de instrução a construírem seus próprios aquecedores, gerando renda às pessoas treinadas e economia de energia aos clientes.

1. Artigo: Publicado em 20/01/2014 - http://folha.com/no1399210

2. Víideo: http://www.youtube.com/watch?v=QKDB93iv1iM

25. São Paulo: Solar Ear - organização que produz e comercializa aparelho auditivos de baixo custo que são recarregáveis a energia solar.

1. Artigo: Publicado em 10/02/2014 - http://folha.com/no1410038

2. Vídeo:http://www.youtube.com/watch?v=XzVTZH9jlLg

26. Rio de Janeiro: Policlínica Granato - clínica médica popular, que integra em um única centro mais de 40 especialidades médicas e odontológicas, exames laboratoriais e de imagem.

1. Artigo: Publicado em 18/02/2014 - http://folha.com/no1413933

2. Vídeo: http://www.youtube.com/watch?v=KxIxkIPFop4

27. Rondônia: AMATA - Empresa que produz e comercializa madeira certificada, gerencia concessões florestais e faz reflorestamentos comerciais.

1. Artigo: Publicado em 21/02/2014 http://folha.com/no1415852

2. Vídeo: http://www.youtube.com/watch?v=DbhsxTntXr8 


\section{Anexo B - Link das reportagens}

1. 04/04/2013 - SEWF: Proceedings do Fórum Mundial de empreendedorismo social (pág.57) Link: http://issuu.com/nesster/docs/2012sewf - brazil proceedings

2. 29/04/2013 - Blog Next Billion Brasil: Brasil27 - uma jornada pelos negócios sociais brasileiros Link: http://brasil.nextbillion.net/blogpost.aspx?blogid=2971

3. Abril/2013 - Revista Contexto Social: Os negócios sociais precisam ser sempre inovadores? (Pág. 34) Link: http://issuu.com/contextosocial/docs/revista contexto 01 web 1

4. 20/05/2013 - Blog A Banca: Brasil27 conhecendo A Banca de ponta a ponta!

Link: http://abancaaudaciajovemcomacao.blogspot.com.br/2013/05/brasil-27-conhecendobanca-de-ponta.html

5. 22/05/2013 - Pequenas empresas \& Grandes Negócios: Projeto viajará o Brasil para estudar negócios sociais

Link: http://revistapegn.globo.com/Revista/Common/0,EMI338348-17180,00.html

6. 05/05/2013 - Blog Empreendedorismo Rosa: Coluna Elas por Eles

Link: http://empreendedorismorosa.com.br/elas-por-eles-pedro-henrique-g-vitoriano/

7. 11/06/2013 - 19/UNIFAL-MG: Projeto Brasil27 viajará pelo Brasil estudando modelos de negócios focados na solução de problemas sociais

Link: http://www.unifal-mg.edu.br/i9unifal/noticias/brasil27

8. 11/06/2013 - Folha de S. Paulo: Jovens viajam pelo Brasil para mapear negócios sociais Link: http://www1.folha.uol.com.br/empreendedorsocial/2013/06/1293015-jovens-viajampelo-brasil-para-mapear-negocios-sociais.shtml

9. 17/06/2013 - Porvir: Brasil27 roda país para registrar negócios sociais Link: http://porvir.org/porfazer/brasil-27-roda-pais-para-registrar-negocios-sociais/20130617

10. 18/06/2013 - IDIS: Projeto colaborativo pretende mapear negócios sociais brasileiros Link: http://www.idis.org.br/acontece/noticias/projeto-colaborativo-pretende-mapearnegocios-sociais-brasileiros

11. 27/06/2013 - Justa Trama: Projeto Brasil27, um novo olhar sobre negócios sociais Link: http://www.justatrama.com.br/noticia/58/projeto-brasil-27-um-novo-olhar-sobrenegocios-sociais

12. 28/06/2013 - Instituto Querô: Projeto estuda negócios focados em problemas sociais Link: http://www.institutoquero.org/oblog/2013/06/projeto-estuda-negocios-focados-emproblemas-sociais/

13. 01/07/2013 - Sustainable Brasil: One of us Link: http://sustainablebrasil.com/one-of-us/

14. 08/07/2013 - Jornal do Comércio (RS): Negócios sociais ganham espaço no mercado Link: http://jcrs.uol.com.br/site/noticia.php?codn=128736

15. 21/07/2013 - Blog do Braulio (GO): Projeto Brasil27 Link: http://www.blogdobraulio.com/2013/07/projeto-brasil-27.html

16. 24/07/2013 - Papo de Homem: Descobrindo o Brasil dos negócios sociais Link: http://papodehomem.com.br/descobrindo-o-brasil-dos-negocios-sociais/

17. $25 / 07 / 2013$ - Catraca Livre: Projeto quer divulgar negócios sociais bem-sucedidos de todo o Brasil Link: http://catracalivre.com.br/geral/educacao-empreendedora/indicacao/projeto-querdivulgar-negocios-sociais-bem-sucedidos-de-todo-o-brasil/

18. 25/07/2013 - Setor3 (Senac-SP): Jovens percorrem o país e estimulam o empreendedorismo social com divulgação de modelos de negócios vencedores

Link:http://www.setor3.com.br/jsp/default.jsp?tab=00002\&newsID=a6191.htm\&subTab=00000\& $\underline{\text { uf }=\& \text { local }=\& \text { testeira }=99 \& l=\& \text { template }=58 . \text { dwt } \& u n i t=\& \text { sectid }=189}$

19. Julho/2013 - Revista Empreendedor: Espírito altruísta - Empreendedorismo de negócios sociais, um passo adiante para o desenvolvimento sustentável

Link:http://www.oficinadacomunicacao.inf.br/new/download/2013/Abraps/Artigo\%20Revista\%2 OEmpreendedor\%20Julho\%202013.pdf

20. 18/09/2013 - Blog Next Billion Brasil: O Brasil colaborativo: Projeto Brasil27 mapeia negócios sociais com apoio de voluntários em todo o país

Link: http://brasil.nextbillion.net/blogpost.aspx?blogid=3049

21. 20/09/2013 - Idesam: Conhecendo o projeto Brasil27

Link: http://idesam.org.br/conhecendo-o-projeto-brasil-27/\#.UkW-d4ZQFe8 
22. 25/09/2013 - Territórios em Rede - Sebrae: Projeto divulga exemplos de negócios sociais em todo o País

Link: http://www.territoriosemrede.com.br/25/09/2013/projeto-divulga-exemplos-negociossociais-pais/

23. 14/10/2013 - Instituto Votorantim: Impacto positivo e rentabilidade: o campo dos negócios sociais no Brasil

Link: http://www.institutovotorantim.org.br/pt-

br/fiqueDentro/noticias/Paginas/131014 impactoPositivoRentabilidadeCampoNegociosSociaisBra sil.aspx

24. 18/11/2013 - Folha Vitória: Projeto Brasil27 no ES

Link: http://www.folhavitoria.com.br/economia/blogs/negocios-de-sucesso/2013/11/18/projetobrasil-27-no-

es/?fb action ids $=10201913214825680 \& f b$ action types=og.likes\&fb source=aggregation\&fb a ggregation $\mathrm{id}=288381481237582$

25. 20/11/2013 - Folha Vitória: Empreendedorismo Social (TV) Link: http://www.folhavitoria.com.br/videos/2013/11/empreendedorismo-social-es-tem-osmelhores-indices.html

26. Novembro/2013 - Revista Cidade Nova: O contágio dos negócios do bem Matéria de capa da edição no 571 - Não há link (revista impressa) 